\begin{tabular}{|l|l|}
\hline $\begin{array}{l}\text { 2. To: (Receiving Organization) } \\
\text { Distribution }\end{array}$ & $\begin{array}{l}\text { 3. From: (Originating Organization) } \\
\text { ICF Kaiser Analytical Services }\end{array}$ \\
\hline 5. Proj/Prog.JDept/Div.: & 6. Cog. Engr.: \\
TANK FARMS & G.R.Wagenblast \\
\hline
\end{tabular}

8. Originator Remarks:

11. Recelver Remarks:
4. Related EDT No.:

NA

7. Purchase Order No.:

NA

9. Equip./Component No.:

NA

10. System/B/dg/Facility:

NA

12. Major Assm. Dwg. No.:

NA

13. Permit/Permit Application No.:

NA

14. Required Response Date:

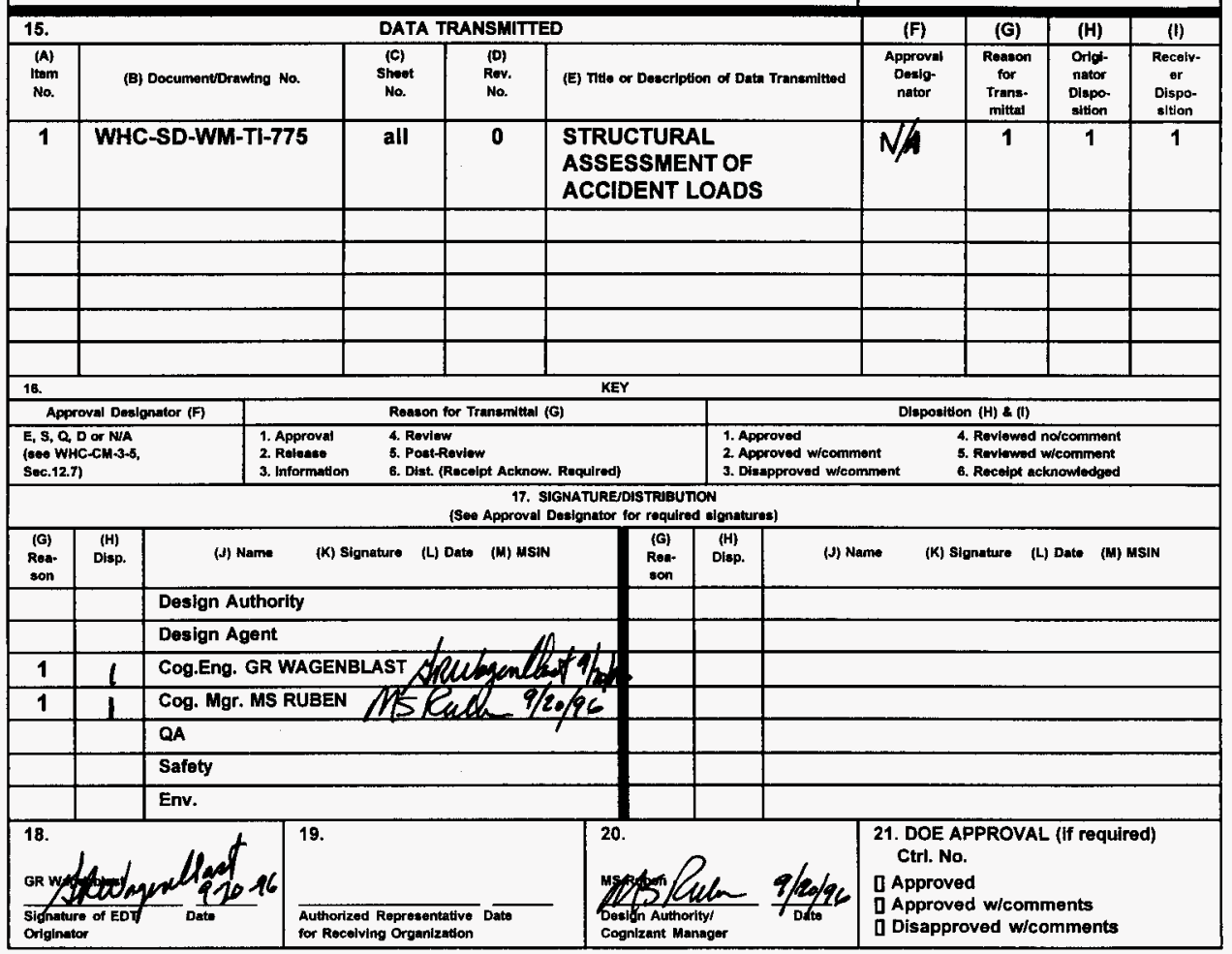

BD-7400-172-2 (05/96) GEF097 
WHC-SD-WM-TI-775, Rev. 0

\section{STRUCTURAL ASSESSMENT of ACCIDENT LOADS}

GR Wagenblast

ICF KAISER, Richland, WA 99352

U.S. Department of Energy Contract DE-AC06-87RL10930

EDT 612807 UC: 2030

Org Code: $57200 \quad$ Charge Code: N1FW3

B\&R Code: EW 3120071 Total Pages: 173

Key Words: tanks, IMUST, MISF, DCRT, accident loads

Abstract: Structural assessments were made for specific accident loads for specific catch, receiver, and storage tanks. The evaluation herein represents level-of-effort order-of-magnitude estimates of limiting loads that would lead to collapse or rupture of the tank and unmitigated loss of confinement for the waste. Structural capacities were established using failure criteria. Compliance with codes such as ACI, ASCE. ASME, RCRA, UBC. WAC, and DOE Orders was NOT maintained. Norma 1 code practice is to prevent failure with margins consistent with expected variations in loads and strengths and confidence in analysis techniques. The evaluation herein represent estimates of code limits without code load factors or code strength reduction factors, and loading beyond such a limit is considered as an onset of some failure mode. The exact nature of the failure mode and its relation to a safe condition is a judgement of the analyst. Consequently, these RESULTS SHALL NOT BE USED TO ESTABLISH OPERATING OR SAFETY LOAD LIMITS FOR THESE TANKS.

TRADEMARK DISCLAIMER. Reference herein to any specific commercial product. process, or service by trade name, trademark, manufacturer, or otherwise, does not necessarily constitute or imply its endorsement. recommendation. or favoring by the United States Government or any agency thereof or its contractors or subcontractors

Printed in the United States of America. To obtain copies of this document. contact: WHC/BCS Document Control Services. P. 0. Box 1970. Mailstop H6-08. Richland WA 99352. Phone (509) 372-2420: Fax (509) 376-4989.
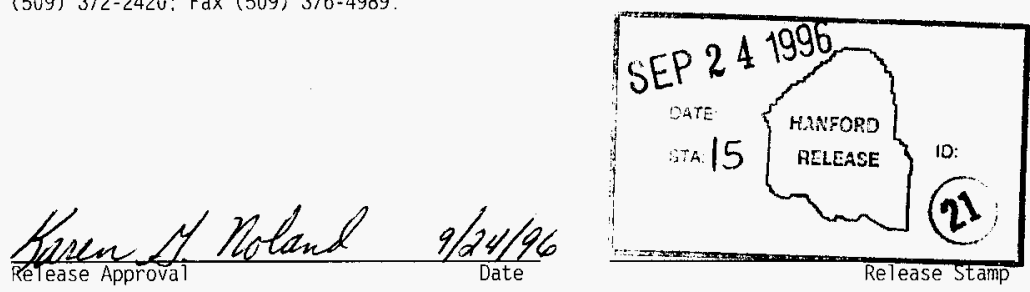

\section{Approved for Public Release}




\section{Structural Assessment of Accident Loads for FSAR}

May 28, 1996

\section{objective}

The objective is to perform structural assessments of specific tanks subjected to accident conditions. Results from the assessment establish either the limiting load that will not result in structural failure or the potential for defined load or condition to cause structural failure. In either case, the affect of the structural failure which is to be evaluated in the assessment is the loss of confinement for the waste, i.e., when an unobstructed opening or path is created between the waste and atmosphere. Therefore, the structural failures that will be evaluated in this assessment are those that would cause the collapse or rupture of the tank structure. Openings in the joints between cover blocks, temporary lifting of cover blocks, and damage to HVAC systems will not be evaluated.

The results from these assessments will be based on failure limit analyses. Compliance with codes such as ACI, ASCE, ASME, UBC, RCRA, WAC is not maintained. Therefore, these results can not be applied to establish operations load limits for these tanks. It should be recognized that normal code practice is to prevent failure with margins consistent with expected variations in loads and strengths, economics of design, and confidence in analysis techniques. The efforts herein represent level-of-effort estimates of code limits without strength reduction factors, and loading beyond such a limit is considered as an onset of some failure mode. The exact nature of the failure mode and its relation to openings and lack of confinement is a judgement on the part of the analyst. Detailed physical calculations to determine sizes of openings and sequences of failures is beyond the scope of this effort. In some instances, results indicate that the structure is not satisfactory with normal loads. These indications are not conclusive, and they might change with refined analysis. Consequently, failure under current conditions is not conclusive.

Results are summarized in the section on task descriptions and results.

Details of the analyses are given in the appendices as indicated in the task descriptions and results. Numbering of these appendices generally follows the task numbering except for tasks have been combined for efficiency. 


\section{Scope}

This work plan will cover structural assessments for the following tanks in each defined group. Equipment components such as riser, pumps, instruments and HVAC systems are not included in this work scope.

Catch Tanks (CT)

241-A-302-A

241-A-417

241-AX-152

241-AZ-151

241-AZ-154

241-ER-311

241-EW-151

241-S-304

241-TX-302-C

241-U-301-B

241-UX-302-A

Double-Contained Receiver Tanks (DCRT)

244-A Lift Station

241-A-350 Lift Station

244-BX Catch Station

244-CR-003 Vault Tank

244-S Lift Station

244-TX Catch Station

244-U Catch Station

200-Series Single-Shell Tanks (SSIs)

241-B

241-C

241-T

241-U

100-Series Single-Shell Tanks

All Tanks

Double-Shell Tanks (DSTs) 


\section{A11 Tanks}

Units

Efficient units, from the viewpoint of drawings and support material, are found throughout the document without conversion. Some may need explanation as follows.

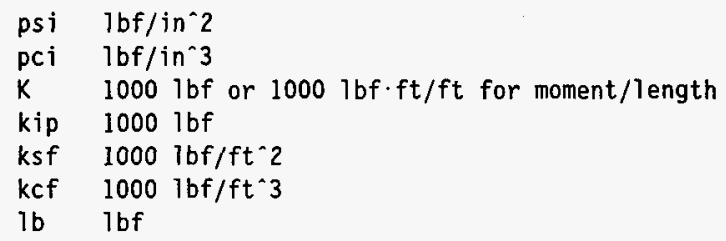

Additional notations in the appendices are as follows

$\begin{array}{ll}\# & \text { lbf } \\ \text { " } & \text { in. } \\ \text {, } & \mathrm{ft}\end{array}$

\section{Task Descriptions and Results}

\section{For DCRTs, Catch Tanks, and 200-Series SSTs}

Determine the maximum limit for the loads described in tasks 1 through 4 .

\section{Concentrated Static Surface Load}

Determine the maximum concentrated static load that can be applied at the soil surface, either directly over a buried structure or adjacent to a buried structure, and not result in a loss of confinement. The assumed contact area shall be based the maximum possible pressure loading for the soil.

Results. See Table 1.1. Two directly buried steel tanks cannot be shown satisfactory under existing soil loads, but no opening to the atmosphere is expected if the tanks collapse. All other cases have various concentrated load capacities ranging from 6 kips upward.

Details. See Appendix 1. 
2. Impact Energy from Dropped Equipment.

Determine the maximum potential energy for equipment that would not result in a loss of confinement if the equipment were dropped. This energy limit shall be the minimum for any position over the tank. Provide the results as a function of contact area; ranging from a cross section area of $0.1 \mathrm{ft}^{2}$ to $2.0 \mathrm{ft}^{2}$ (three data points minimum). The shape assumed for the contact area shall produce the lowest allowed energy value.

Results. An equipment of 20,000 pounds with 2 feet diameter base was considered. The results of the evaluations indicate that the perforation of the cover block from the falling equipment is not realistic. The energy as high as 29,000,000 inch-pounds would be needed to perforate a 20 inch thick cover block if a 20,000 pound equipment is dropped from a height of 120 feet. See Table 2.1. On the other hand, the results of the evaluations indicate that the cover blocks do not have adequate bending strength to resist impact. A failure of the cover block leading to an opening is most likely to occur due to the energy from the falling of a $20,000 \mathrm{lb}$ equipment from any height. See Table 2.2. The impact with the soft ground was considered for three drop heights from $10 \mathrm{ft}$ to $20 \mathrm{ft}$. The results show that the vault wall and roof for the DCRTs, catch tanks and the 200 series SSTs are adequate to withstand the impact. See Table 2.3.

Details. See Appendix 2.

3. Internal Transient Pressure Caused by Hydrogen Deflagration.

Determine the maximum peak pressure for a Hydrogen deflagration inside the primary waste tank that would not result in a loss of confinement. Peak pressures above 120 psig do not need to be evaluated. For the DCRTs, the peak pressure is applied inside the steel tank. Assume the pressure rise time is essentially instantaneous.

Results. See Table 3.1. Tanks marked OK in the status column will not resuit in a loss of confinement given the data and assumptions used in the detailed calculations. The remaining cases are considered to yield an opening, because (1) the steel tank was not evaluated for pressurization (lack of data), or (2) there is no steel tank, or (3) the steel tank pressure exceeded capacity. 
Details. See Appendix 3.

4. Seismic Event

Determine the maximum ZPA for a free-field ground motion that would not result in a loss of confinement. Ground motions in both the horizontal and vertical directions shall be evaluated to determine which one controls. Combination of ground motions in more than one orthogonal direction is not required, unless a significant increase in the result is anticipated. If multiple directions are combined, the magnitude of the ground motion shall be the same for each direction. The ground motion applied in this evaluation shall be scaled from the response spectra defined in SDC 4.1 for the Hanford-Site. For this evaluation assume the steel tanks in the DCRTs fail during the seismic event.

Results. Results are summarized in Table 4.1 along with the maximum ZPA and failure mode. Some directly buried tanks such as 241-ER-311 are shown to collapse without seismic loading, i.e., they were not shown good for static loading alone. As such, the simple analysis procedure could well overestimate the static loading, and refined analys is would be required. Given a collapse in a seismic event, the tank volume is small compared to a characteristic soil volume above it, and in the analyst's judgement a significant opening is unlikely. Pit wall and cover block collapse is assumed to lead to an opening corresponding to the plan form. No further failure sequence evaluated. In the case of the lower wall of 244-CR, a refined analysis might show integrity with static soil loads by considering plate edge restraints and distribution of moments in the wall. Consequently, failure under current conditions is not implied.

Evaluate the specific loads and conditions described in tasks 6 through 8 .

5. Internat Vacuum Caused by Organic Pool Fire

Assess the potential for a quasi-static vacuum of -8 psig to cause a loss of confinement. This vacuum is caused by an organic pool fire on the waste surface, followed by cooling of the high temperature gasses inside the tank. Assume the concrete tanks remain at normal operating temperatures. Assume the steel tanks can reach $200 \mathrm{~F}$.

Results. Some directly buried steel tanks are not satisfactory against buckling, but an opening to the atmosphere is not expected unless liquid is squeezed out through a normal opening by tank collapse under soil 
load. Aside from these directly buried tanks, roof and floor structures are not expected to collapse, and openings to the atmosphere are not expected.

Details. See Appendix 5.

6. Internal Hydrostatic Load

Assess the potential for the hydrostatic load on the tank wall to cause a loss of confinement. Assume the tank is full of fluid and the specific gravity for the fluid is 2.0 .

Result. No opening to the atmosphere is expected with the internal hydrostatic loads.

Details. See Appendix 1.

7. High Temperature Waste Sludge

Assess the potential for high temperature waste sludge to cause a loss of confinement. Assume the sludge temperature is $600 \mathrm{~F}$ and the sludge is stored in the tank for 1 year. Apply the sludge temperature as the inside surface temperature for the bottom half of the tank wall and apply an assumed inside surface temperature of $250 \mathrm{~F}$ for the upper half or the tank wall and dome. For DCRTs, where the steel tank is not in direct contact with the vault of caisson structure, assume a temperature of $250 \mathrm{~F}$ for entire inside surface of the vault structure, including the cover. Assume a through wall temperature gradient for concrete foundations, walls, and covers that is $\frac{1}{2}$ of the difference between the inside surface temperature and an assumed ambient temperature of $50 \mathrm{~F}$, unless a more appropriate temperature gradient can be established and justified.

Result. No roof, cover block or dome collapse is expected from the thermal loading. Consequently, no significant opening to the atmosphere is expected. See Tables 7.1 and 7.2.

Details. See Appendix 7.

8. Aging and Degradation

Assess the potential for aging and degradation mechanism to cause a loss 
of containment. Specifically address how each of the following mechanisms could individually affect confinement of the waste.

- Corrosion

- High temperature waste

- Thermal cycling

Results.

Corrosion. Pitting corrosion is local and is not expected to cause tank collapse; leakage is possible. Uniform corrosion is not a problem for about 60 years of tank life. Stress corrosion in not a concern for tank collapse. Reinforcement corrosion is of concern only as a result of tank leakage. Waste leaking past a steel liner can migrate directly through uncracked concrete, but obviously at a much lower rate than along a crack.

High temperature waste. This is discussed in Item 7.

Thermal cycling. The temperature of the vault at each cycle is below moderately high temperature, say $250 \mathrm{~F}$, and thermal cycling does not affect the dome integrity.

Details. See Appendix 8.

\section{For DCRIs only}

9. Pressure Transient Caused by Gasoline Fire.

Assess the potential for a transient pressure, external to the primary waste tank, to cause a loss of confinement. The pressure transient for this accident is caused the 20 gallons of gasoline being spilled into the vault that contains the primary waste tank. The gasoline is then vaporized and ignited. Assume a peak pressure of $140 \mathrm{psig}$ and a pressure rise time that is essentially instantaneous.

Results. None of the structures survive this scenario, and all roofs and cover blocks are expected to be blown off with a full opening to the atmosphere. Tanks in vaults with the gasoline ignition are expected to collapse if evaluated in Table 3.1, i.e., if information was available. See Table 9.1.

Details. See Appendix 5. 
For Catch Tanks Only

10. Uniform Static Surface Load

Determine the maximum uniform static surface load that can be applied over the catch tank and not result in a loss of confinement.

Results. See Table 1.1. Two directly buried steel tanks cannot be shown satisfactory under existing soil loads. No opening to the atmosphere is expected were the tanks to collapse. All other cases have various uniform load capacities ranging from $0.26 \mathrm{ksf}$ upward.

\section{Eor DSTs and 100-Series-SSTs}

11. Internal Vacuum Caused by Organic Pool Fire

Assess the potential for a quasi-static vacuum of -8 psig to cause a loss of confinement. This vacuum is caused by an organic pool fire on the waste surface, followed by cooling of the high temperature gasses inside the tank. Assume the concrete tanks remain at normal operating temperatures. Assume the steel tanks can reach $200 \mathrm{~F}$.

Results. Same as Item 5.

Details. See Appendix 5.

Eor DSTs only

12. Pressure Transient Caused by Gasoline Fire.

Assess the potential for a transient pressure, external to the primary waste tank, to cause a loss of confinement. The pressure transient for this accident is caused the 20 gallons of gasoline being spilled into the annulus between the primary and secondary tank 1 iners. The gasoline is then vaporized and ignited. Assume a peak pressure of $140 \mathrm{psig}$ and a pressure rise time that is essentially instantaneous.

Results. Included with item 9. An opening of about 30 feet in diameter at the crown is expected along with collapse of the primary tank. 
Details. See Appendix 5.

For 100-Series SSIs Only

13. High Concrete Temperatures and Pressure Caused by Organic Nitrate Reaction

Review the attached memo that describes a failure mechanism for $100-$ Series SSTs cause by high temperatures and internal pressure form an intank organic pool fire. Assess whether or not this failure mechanism is expected to occur as described. Provided discussion of the reasoning applied in this assessment.

Results. Dome collapse is considered possible with substantial parts of the dome and soil cover falling into the waste. Two effects pointing to collapse are possible that are not brought up in the memo. First, dome cracking under pressure may be biased toward the center of the dome with less leakage area and higher pressure development. Second, concrete degradation through the thickness may occur with hot gases passing through cracks. Even if the dome did not collapse, it would have severe strength reductions and should be considered unstable.

Details. See Appendix 13.

\section{Additional Notes:}

The following apply to all structural assessments.

* For each accident load or event described herein, the structural failure modes expected to occur first are described in the details along with explanations how these failure modes could affect confinement of the waste.

* A11 structural assessments were performed using simplified methods and bounding analyses. In particular, detailing code requirements were not checked.

* Al1 structural assessments were be based on present existing live and dead loads. In LRFD and ACI code terminology, load factors were taken as unity. Material properties were taken as minimum and strength reduction factors were not assigned.

* The affect of operational loads such as pressure and temperature and the 
affect of the allowed variations in these loads were included.

* Best estimate values for soil properties were used. Soil density is 125 pcf.

* Corrosion was neglected if its affect on the anaiysis results was considered negligible. Otherwise reasonable values for corrosion were selected, and technical justifications for the value were provided.

* Property data for concrete at $600 \mathrm{~F}$ were be extrapolated from property data at $450 \mathrm{~F}$.

* The thermal history for tank C-106 were used to determine initial degraded concrete properties for 100-series SSTs. For all other tanks, the design properties for the concrete were used.

* Openings between the joints in cover blocks are acceptable with respect to the confinement issue.

* Soil density over all tanks is $125 \mathrm{lbf} / \mathrm{ft}^{3}$.

* The structure in not serviceable after the accident load. 
Table 1.1. Uniform and Concentrated Load Summary

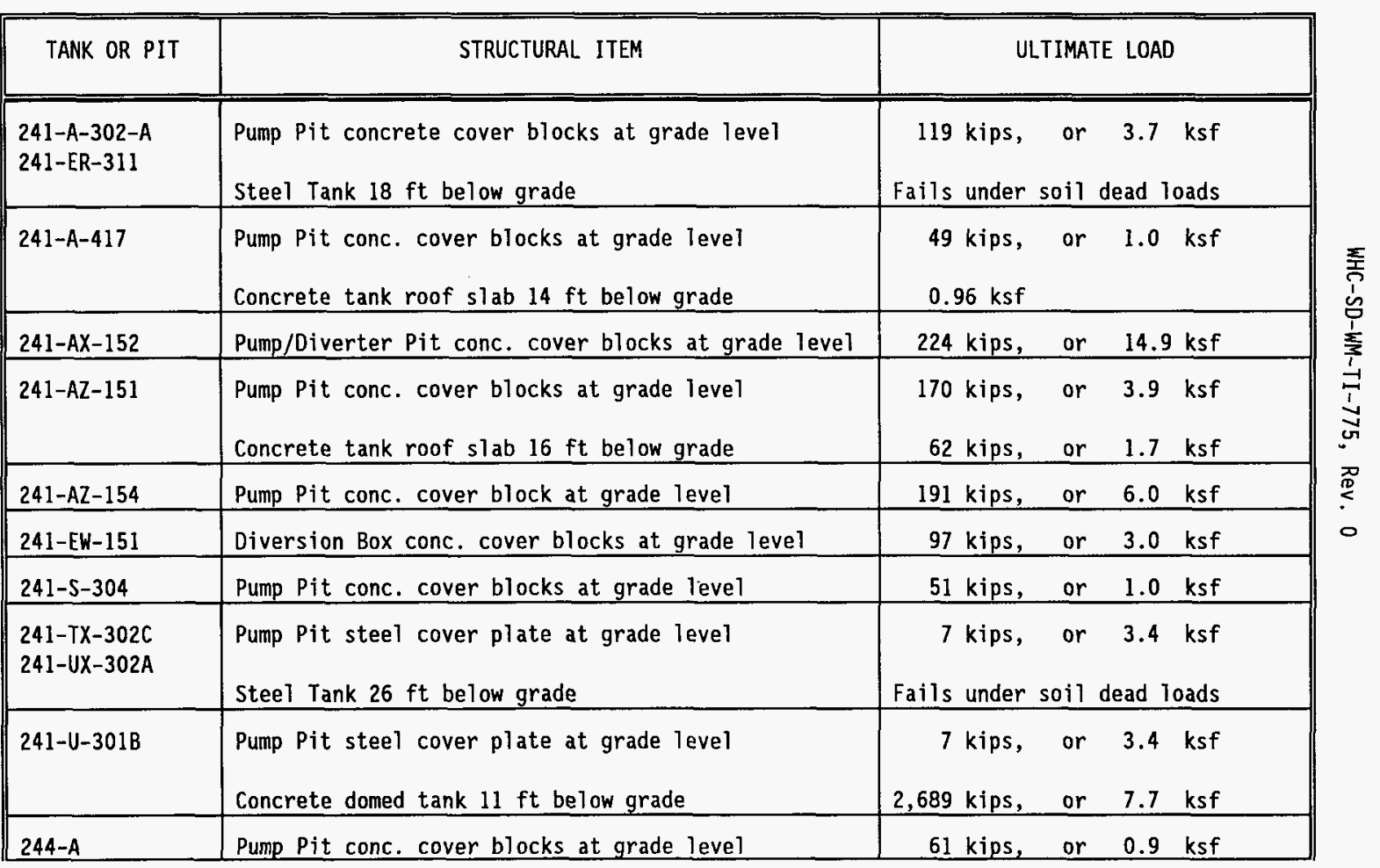


StructuraT Assessments

Page 12

\begin{tabular}{|c|c|c|c|c|}
\hline $241-A-350$ & Pump Pit conc. cover blocks at grade level & 53 kips, & or & $1.2 \mathrm{ksf}$ \\
\hline 244-BX, TX, U & Pump Pit conc. cover blocks at grade level & 70 kips, & or & $1.3 \mathrm{ksf}$ \\
\hline 244-CR-003 & Pump Pit conc. cover blocks at grade level & 53 kips, & or & $2.0 \mathrm{ksf}$ \\
\hline 244-S & Pump Pit conc. cover blocks at grade level & 31 kips, & or & $0.38 \mathrm{ksf}$ \\
\hline 200-Series SST & Concrete Tank roof slab $11 \mathrm{ft}$ below grade & 327 kips, & or & $1.04 \mathrm{ksf}$ \\
\hline
\end{tabular}


KAUEEE IEIVGUVEAMA

HAIVFJAL

WHC-SD-WM-TI-775, Rev. 0

DESIGN ANALYSIS
-

Revision

Page No.

Wo/Job No.

Client WHC

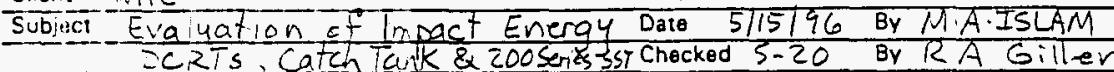
Location 200 Area Revised BY

\section{SUMMARY OF EVALUATIONS}

A. Impact Energy Required to perforate Cover Block (Table 2.1)

\begin{tabular}{|c|c|c|c|c|c|}
\hline \multicolumn{2}{|c|}{ Tank Data } & \multicolumn{2}{|c|}{ Missile Data } & \multicolumn{2}{|c|}{$\begin{array}{l}\text { Energy Reqdi } \\
\text { for perforation }\end{array}$} \\
\hline $\operatorname{Tan} K$ & $\begin{array}{l}\text { Cover Depth } \\
\text { (in) }\end{array}$ & $\begin{array}{c}\text { Weight } \\
\text { (los) }\end{array}$ & $\begin{array}{c}\text { Diameter } \\
\text { (in) }\end{array}$ & $\begin{array}{l}\text { Height of } \\
\text { Fall }(h) \\
\text { (in) }\end{array}$ & $\begin{array}{l}\text { Energy, } \\
E=W h \\
(\text { in- } 16 s)\end{array}$ \\
\hline $\begin{array}{c}241-A-350 \\
(D C R T)\end{array}$ & 20 & 20,000 & 24 & $\begin{array}{l}1440 \\
(120 F T)\end{array}$ & $28,800,000$ \\
\hline
\end{tabular}

B. Impact with Yielding Surface (Ground)

$$
\text { (Tule 2.2) }
$$

\begin{tabular}{|c|c|c|c|c|c|c|c|c|}
\hline Tank D & & Anal & sis & ta & med) & Res & & \\
\hline Tank & $\begin{array}{c}\text { So i/Cover } \\
\text { Depth } \\
\text { (in) }\end{array}$ & $\begin{array}{l}\text { Missile } \\
\text { Weight, } \\
\text { W (ibs) }\end{array}$ & $\begin{array}{l}\text { Height } \\
\text { of fall, } \\
h(\text { in) }\end{array}$ & $\begin{array}{c}\text { Soilde } \\
Y_{(\pi)}\end{array}$ & $\begin{array}{l}\text { Soil Frictio } \\
\text { Angle, } \\
\text { (Xeg.) }\end{array}$ & $\begin{array}{l}\text { Force } \\
\text { (Impact } \\
\text { FI (Ibs) }\end{array}$ & $\begin{array}{l}\text { Missile } \\
\text { penetratio } \\
\text { in soil } \\
\text { (in) }\end{array}$ & \\
\hline $\begin{array}{r}200 \text { Series SST } \\
241-B, C, T, U\end{array}$ & $\begin{array}{c}144 \\
(12 \mathrm{Ft})\end{array}$ & 20,000 & 120 & 125 & 30 & 55,897 & $74 \cdot 5$ & $\begin{array}{l}\text { FI dissipates } \\
\text { significantly } \\
\text { as it approache } \\
\text { Tank roof. } \\
\text { There fore, Tank } \\
\text { Foof pill maintair } \\
\text { its integrify. }\end{array}$ \\
\hline
\end{tabular}


KAISER ENGINEERS HANFORD
WHC-SD-WM-TI-775, Rev, 0

DESIGN ANALYSIS
Sac. No.

Revision

Page No. 2 of

Client WHC WO/Job No.

Subject Evaluation of Impact Energy

Location 200 Area

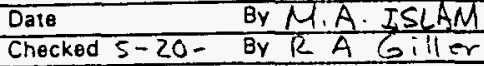

Revised

By

SUMMARY OF EVALUATIONS CONTD.

C. Impact with nonyielding surface eng. coverblock, pit, riserete. (Table $2 . I$ )

DCRTs

* using an equipment weight, $w=20,000$ lbs

\begin{tabular}{|c|c|}
\hline Tank Data & * Energy Recd to
\end{tabular}
Cause Bending Failure in Cover Block.

Group

Listed Tanks
$241-A \cdot 350$
$244-T X, 244-U$
$244-8 X$

Rebar (i n-16)

\begin{tabular}{|l|l}
\hline 1 & $241-A \cdot$ \\
\hline 2 & $\begin{array}{l}244-T X \\
244-B X\end{array}$ \\
\hline 3 & $244-C R$ \\
\hline 4 & $244-A$ \\
\hline
\end{tabular}

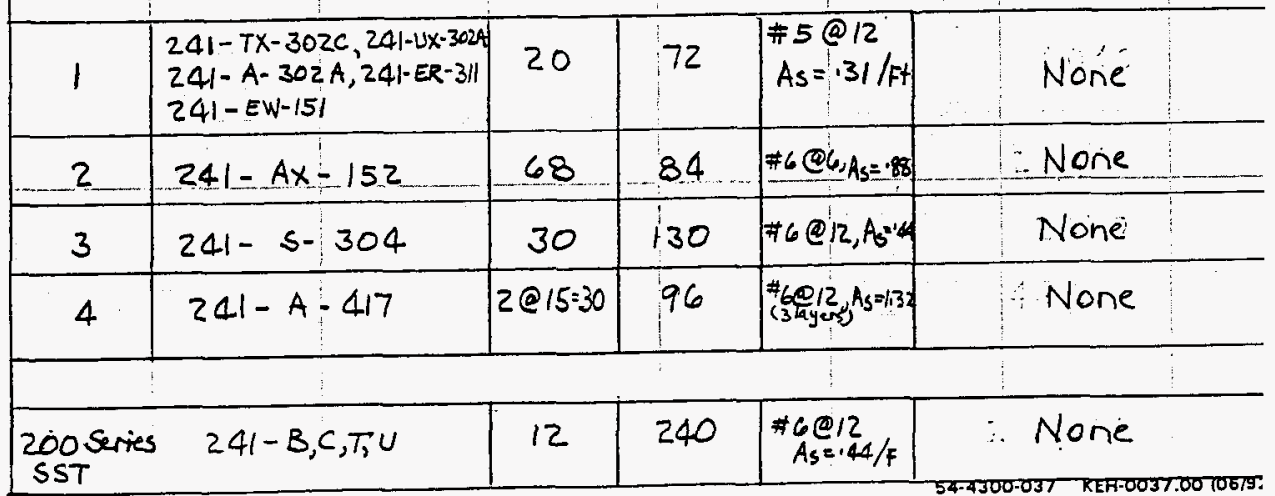

14

None

None

$A_{s}=1.58 / \mathrm{Ft}$

$\# 6 \oplus 12$
As $=144 / F+$

$252\left|\begin{array}{l}\# 6 @ 12 \\ A_{s}=144 / A\end{array}\right| \quad$ None

$24 \quad 252 \quad$\begin{tabular}{l|l}
$A 6$ & \\
$A_{3}=144 / A$
\end{tabular} 
Table 3.1 Internal Transient Pressure Summary

\begin{tabular}{|c|c|c|c|c|c|c|}
\hline & VESSEL MATERIAL & $\begin{array}{l}\text { VESSEL } \\
\text { DIA }\end{array}$ & $\begin{array}{l}\text { WALL } \\
\text { THICKNESS } \\
\end{array}$ & $\begin{array}{l}\text { WALL STRESS } \\
\text { (1) }\end{array}$ & $\begin{array}{l}\text { YIELD } \\
\text { STRESS } \\
\end{array}$ & STATUS \\
\hline \multicolumn{7}{|l|}{ Catch Tanks } \\
\hline $241-\mathrm{A}-302-\mathrm{A}$ & $\begin{array}{l}\text { carbon steel } \\
\text { direct buried }\end{array}$ & $9 \cdot-0 "$ & $9 / 16^{\prime \prime}$ & $23,040 \mathrm{psi}$ & 30,000 psi & $\mathrm{OK}$ \\
\hline $241-A-417$ & \multicolumn{3}{|c|}{ lined concrete vault, no vessel } & & & Vault Fails \\
\hline $241-\mathrm{AX}-152$ & \multicolumn{3}{|c|}{ lined concrete vault, no vessel } & & & Vault Fails \\
\hline $241-A Z-151$ & \multicolumn{3}{|c|}{ lined concrete vault, no vessel } & & & Vault Fails \\
\hline $241-\mathrm{AZ}-154$ & \multicolumn{3}{|c|}{ lined concrete vault, no vessel } & & & Vault Fails \\
\hline $241-$ ER-311 & $\begin{array}{l}\text { carbon steel } \\
\text { direct buried } \\
\end{array}$ & $9^{\prime}-0 "$ & $9 / 16^{\prime \prime}$ & $23,040 \mathrm{psi}$ & $30,000 \mathrm{psi}$ & ок \\
\hline $241-\mathrm{EW}-151$ & stainless steel & $4 \cdot-5 "$ & $3 / 8 "$ & $17,280 \mathrm{psi}$ & $25,000 \mathrm{psi}$ & OK \\
\hline $241-S-304$ & carbon steel & $9 \cdot-0 "$ & $5 / 8^{\prime \prime}$ & $20,736 \mathrm{psi}$ & $30,000 \mathrm{psi}$ & OK \\
\hline $241-\mathrm{TX}-302 \mathrm{C}$ & $\begin{array}{l}\text { carbon steel } \\
\text { direct buried }\end{array}$ & $9^{\prime}-0^{\prime \prime}$ & $1 / 2 "$ & $25,920 \mathrm{psi}$ & $30,000 \mathrm{psi}$ & OK \\
\hline $241-U-301 B$ & \multicolumn{3}{|c|}{ precast concrete vault, no vessel } & & & Vault Fails \\
\hline $241-U X-302 A$ & $\begin{array}{l}\text { carbon steel } \\
\text { direct buried }\end{array}$ & 9- '0" & $1 / 2 "$ & 25,920 psi & $30,000 \mathrm{psi}$ & $\mathrm{OK}$ \\
\hline \multicolumn{7}{|c|}{ Double-Contained Receiver Tanks } \\
\hline $244-A$ & & & & not evaluated & & $\begin{array}{l}\text { Vault Fails } \\
\text { See Appendix } \\
5 \\
\end{array}$ \\
\hline $241-\mathrm{A}-350$ & stainless steel & $4 \cdot-5 \prime$ & $3 / 8^{\prime \prime}$ & 17,280 psi & $25,000 \mathrm{psi}$ & $\mathrm{OK}$ \\
\hline
\end{tabular}


Structural Assessments

Page 16

\begin{tabular}{|c|c|c|c|c|c|c|}
\hline $244-\mathrm{BX} / \mathrm{TX} / \mathrm{U}$ & carbon steel & $12^{\prime}-0^{\prime \prime}$ & $1 / 4^{\prime \prime}$ & 69,120 psi & $30,000 \mathrm{psi}$ & $\begin{array}{l}\text { Tank } \\
\text { Ruptures } \\
\text { Vault Eails } \\
\text { See Appendix } \\
5\end{array}$ \\
\hline $244-C R-003$ & stainless steel & & $3 / 8^{\prime \prime}$ & not evaluated & & $\begin{array}{l}\text { Vault Fails } \\
\text { See Appendix } \\
5\end{array}$ \\
\hline $244-S$ & carbon steel & $15^{\prime}-0^{\prime \prime}$ & $1 / 4 "$ & $86,000 \mathrm{psi}$ & $30,000 \mathrm{psi}$ & $\begin{array}{l}\text { Tank } \\
\text { Ruptures } \\
\text { Vault Fails } \\
\text { See Appendix } \\
5\end{array}$ \\
\hline \multicolumn{7}{|c|}{ 200-Series Single Shell Tanks } \\
\hline $241-B / C / T / U$ & \multicolumn{3}{|c|}{ lined concrete vault, no vessel } & & & vault Eails \\
\hline
\end{tabular}


Table 4.1 Seismic Summary

\begin{tabular}{|l|l|l|l|}
\hline Item & ZPA, g & Failure Mode & Opening \\
\hline \hline $241-A-201 A$ & $>1.0$ & & No \\
\hline $241-A-417$ & 0.60 & $\begin{array}{l}\text { Roof/soil collapse } \\
\text { Pit wall collapse }\end{array}$ & Yes \\
\hline $241-A X-152$ & 0.35 & Pit wall collapse & Yes \\
\hline $241-A Z-151$ & 0.38 & Pit wall collapse & Yes \\
\hline $241-E R-311$ & 0.00 & Collapse & No - buried deep \\
\hline $241-E W-151$ & $>1.0$ & & No \\
\hline $241-T X-302 C$ & 0.32 & Collapse & No - buried deep \\
\hline $241-U X-302 A$ & $>1.0$ & & No \\
\hline $241-U-301-B$ & $>1.0$ & & No \\
\hline $241-A-350$ & $>1.0$ & & No \\
\hline $244-A$ & 0.82 & Pit wall collapse & Yes \\
\hline $244-B X / T X / U$ & 0.39 & Pit wall collapse & Yes \\
\hline $244-C R$ & 0.00 & $\begin{array}{l}\text { Lower wall collapse, } \\
\text { refined static analysis } \\
\text { required }\end{array}$ & Yes \\
\hline $244-S$ & Cover blocks collapse & Yes \\
\hline $241-S-304$ & 0.60 & Caisson roof collapse & Yes \\
\hline $200-S$ & 0.48 & Roof collapse & Yes \\
\hline
\end{tabular}


Table 5.1 Internal Vacuum Sunmary

\begin{tabular}{|c|c|c|c|}
\hline Tank & Structural Item & OK/NG by Item & Overall \\
\hline $241-A-302-A$ & Steel tank & OK & OK \\
\hline $241-A-417$ & Tank roof & OK & OK \\
\hline $241-A X-152$ & Tank roof & $\mathrm{OK}$ & OK \\
\hline 241-AZ-151 & $\begin{array}{l}\text { Tank roof } \\
\text { Tank side wall }\end{array}$ & $\begin{array}{l}\text { OK } \\
\text { Marginal }\end{array}$ & OK, no opening \\
\hline $241-E R-311$ & Steel tank & NG & NG, no opening \\
\hline |241-EW-151 & $\begin{array}{l}\text { Steel tank } \\
\text { Vault roof }\end{array}$ & $\begin{array}{l}\text { NG } \\
\text { OK }\end{array}$ & OK \\
\hline $241-T X-302-C$ & Steel tank & $\mathrm{OK}$ & OK \\
\hline $241-U X-302-A$ & Steel tank & NG & NG, no opening \\
\hline $241-U-301-B$ & $\mathrm{R} / \mathrm{C}$ tank & $\mathrm{OK}$ & OK \\
\hline $241-A-350$ & $\begin{array}{l}\text { Steel tank } \\
\text { Caisson roof }\end{array}$ & $\begin{array}{l}\text { Not evaluated } \\
\text { OK }\end{array}$ & OK \\
\hline $244-B X / T X / U$ & $\begin{array}{l}\text { Steel tank } \\
\text { Vault roof }\end{array}$ & $\begin{array}{l}\text { NG } \\
\text { OK } \\
\end{array}$ & OK \\
\hline $244-C R$ & $\begin{array}{l}\text { Steel tank } \\
\text { Vault roof }\end{array}$ & $\begin{array}{l}\text { Not evaluated } \\
\text { OK }\end{array}$ & OK \\
\hline $244-S$ & $\begin{array}{l}\text { Steel tank } \\
\text { Caisson roof }\end{array}$ & $\begin{array}{l}N G \\
O K\end{array}$ & OK \\
\hline $241-S-304$ & Steel tank & OK & OK \\
\hline 200 Series & $R / C$ tank & $\mathrm{OK}$ & OK \\
\hline DST/SST & $\mathrm{R} / \mathrm{C}$ tank & OK & OK \\
\hline
\end{tabular}


Table 7.1 material properties at high temperatures

\begin{tabular}{|c|c|c|c|c|c|c|c|}
\hline \multicolumn{8}{|c|}{ DEGRADATION OF MATERIAL PROPERTIES AT HIGH TEMPERATURE } \\
\hline \multirow[t]{2}{*}{ material } & \multirow[t]{2}{*}{ designation } & \multirow[t]{2}{*}{ * } & \multirow{2}{*}{$\begin{array}{c}\text { normal } \\
(p s i)\end{array}$} & \multicolumn{2}{|c|}{$250 \mathrm{~F}$} & \multicolumn{2}{|c|}{$600 \mathrm{~F}$} \\
\hline & & & & (psi) & degradation & (psi) & degradation \\
\hline carbon steel & SA-516 & fy & 32000 & 28750 & $10 \%$ & 23600 & $26 \%$ \\
\hline \multirow{3}{*}{ concrete } & \multirow{3}{*}{$\mathrm{fc}^{\prime} \mathrm{c}=00 \mathrm{psi}$} & $E$ & 3122000 & 2012000 & $36 \%$ & 439000 & $86 \%$ \\
\hline & & $f c$ & 3000 & 2509 & $16 \%$ & 1592 & $47 \%$ \\
\hline & & fst & 217 & 195 & $10 \%$ & 123 & $43 \%$ \\
\hline
\end{tabular}

*material properties:

fy $=$ yield strength,

$E=$ modulus of elasticity,

$\mathrm{fc}=$ compressive strength,

$\mathrm{f}$ st $=$ splitting tensile strength .

NOTE: The duration for concrete at high temperature is one year. Duration is not a factor for steel. 
KAISER ENEINEENSE H'AIVFORCI

WHC-SD-WM-TI-775, Rev. 0 DESIGN ANALYSIS

Revision

Page No.

5 of

CLie1: HES IINGHOUSE HANFOSI COMPANY

wolJob No.

E21425/F6N1A1

Subjiet Tank Farm Accident Load Evaluation Date May 1996 By K.C. Tu High Temperature Waste sludge Checked By Revised

Table 7.2 High Temperature Waste Sludge Summary

\begin{tabular}{|c|c|c|c|c|}
\hline Tank & Structural Item & by Item & Overall & Remark \\
\hline \multicolumn{5}{|c|}{ (6atch Tanks } \\
\hline $241-A-302-A$ & Steel tank & OK & OK & Buried steel tank \\
\hline $241-A-417$ & Tank roof & Shear NG & OK to Atm & conc. w/liner \\
\hline $241-A X-152$ & Cover blocks & OK & OK & concrete tank \\
\hline $241-A Z-151$ & Cover blocks & OK & OK & concrete tank \\
\hline $241-E R-311$ & Steel tank & NG & OK to Atm & $\begin{array}{l}\text { Steel tank buried } \\
\text { deep in soil }\end{array}$ \\
\hline $241-E W-151$ & $\begin{array}{l}\text { Steel tank } \\
\text { Cover blocks }\end{array}$ & $\begin{array}{l}\text { OK } \\
\text { OK }\end{array}$ & OK & $\begin{array}{l}\text { Steel tank inside } \\
\text { concrete vault }\end{array}$ \\
\hline $241-S-304$ & $\begin{array}{l}\text { Steel tank } \\
\mathrm{R} / \mathrm{C} \text { roof }\end{array}$ & $\begin{array}{l}\text { OK } \\
\text { Shear NG }\end{array}$ & OK & \\
\hline $241-T X-302-C$ & Stee] tank & OK & OK & Buried steel tank \\
\hline $241-U-301-B$ & $\mathrm{R} / \mathrm{C}$ tank & NG & OK to Atm & By obeservation \\
\hline $241-U X-302-A$ & Steel tank & $N G$ & OK to Atm & $\begin{array}{l}\text { Steel tank buried } \\
\text { deep in soil }\end{array}$ \\
\hline \multicolumn{5}{|c|}{ Double-Conta ined Receiver Tanks (DCRT) } \\
\hline $241-A-350$ & $\begin{array}{l}\text { Steel tank } \\
\text { Cover blocks }\end{array}$ & $\begin{array}{l}\text { OK } \\
\text { OK }\end{array}$ & OK & \\
\hline $244-A$ & $\begin{array}{l}\text { Steel tank } \\
\text { Cover blocks }\end{array}$ & $\begin{array}{l}\text { OK } \\
\text { OK }\end{array}$ & OK & \\
\hline $244-B X / T X / U$ & $\begin{array}{l}\text { Steel tank } \\
\text { Cover blocks \& roof }\end{array}$ & $\begin{array}{l}\text { OK } \\
\text { OK }\end{array}$ & OK & \\
\hline $244-C R-003$ & $\begin{array}{l}\text { Steel tank } \\
\text { Cover blocks }\end{array}$ & $\begin{array}{l}\text { OK } \\
\text { OK }\end{array}$ & OK & \\
\hline $244-S$ & $\begin{array}{l}\text { Steel tank } \\
\text { Cover blocks }\end{array}$ & $\begin{array}{l}\text { OK } \\
\text { OK }\end{array}$ & OK & \\
\hline \multicolumn{5}{|c|}{200 -series s ringle shel) tanks. } \\
\hline $241-B / C / T / U$ & $\mathrm{R} / \mathrm{C}$ tank w/ liner & Shear NG & OK to $\mathrm{A}$ & \\
\hline
\end{tabular}

Notes:NG $=$ no good (fails structural criteria)

$O K=$ satisfies structural criteria

OK to $\mathrm{Atm}=$ no significant opening to atmosphere

Shear $N G=$ no good for structural shear criteria but not collapse 20 
Table 9.1. Gasoline Ignition Surmary

\begin{tabular}{|l|l|l|l|}
\hline Tank & Structural Item & OK/NG by item & Overall \\
\hline \hline $241-A-350$ & Caisson roof & NG & Fully open \\
\hline $244-B X / T X / U$ & Vault roof & NG & Fully open \\
\hline $244-C R$ & Vault roof & NG & Fully open \\
\hline $244-S$ & Caisson roof & NG & Fully open \\
\hline $241-S-304$ & Caisson roof & NG & Fully open \\
\hline DST & R/C dome & NG & Open, 25' dia. \\
\hline
\end{tabular}

Notes: $\quad N G=$ no good (fails structural criteria)

$O K=$ satisfies structural criteria 
P. 1-1

WHC-SD-WM-TI-775, Rev. 0

Appendix 1

Calculations for Uniform and Concentrated Loads and Hydrostatic Pressure

22 
Concentrated and distributed failure loads;

The tank farm catch tanks, double containment receiver tanks (DCRT), and 200 series single-shell tanks (SST) were evaluated for external concentrated and distributed failure loads. For this evaluation, failure is defined as the ultimate strength of the concrete cover blocks, concrete slab, or concrete dome, and the yield strength of the steel cover plates. See Table 1.1 for a tank by tank list of the calculated failure loads for each tank.

Three tanks were calculated to fail under soil loads. These horizontal steel tanks are buried under 18 to $26 \mathrm{ft}$ of soil, and when they fail they will buckle inward filling up with soil. This type of tank failure may contaminate the soil 18 to $26 \mathrm{ft}$ below grade but will not be a release to the atmosphere.

The specific design property assumptions used are stated in the calculations. In addition, assumptions on failure mode and critical member have also been made. Based on engineering judgement, we have concluded that concrete cover blocks, slabs and tank domes will fail before the tank walls, pit walls or foundations.

Hydrostatic Pressure;

The evaluation of hydrostatic loads applied to the catch tanks, DCRTs, and SSTs is based on engineering judgement. We have concluded that hydrostatic pressure may cause cracks in the walls and leak liquids to the surrounding soil but liquids would not reach the soil surface. Cracks and leaks near the bottom of buried tank rarely cause structural collapse of these type tanks. 
Table 1.1. Uniform and Concentrated Load Summary

\begin{tabular}{|c|c|c|}
\hline TANK OR PIT & STRUCTURAL ITEM & ULTIMATE LOAD \\
\hline $\begin{array}{l}241-A-302-A \\
241-E R-311\end{array}$ & $\begin{array}{l}\text { Pump Pit concrete cover blocks at grade level } \\
\text { Steel Tank } 18 \mathrm{ft} \text { below grade }\end{array}$ & $\begin{array}{l}119 \text { kips, or } 3.7 \text { ksf } \\
\text { Fails under soil dead loads }\end{array}$ \\
\hline $241-A-417$ & $\begin{array}{l}\text { Pump Pit conc. cover blocks at grade level } \\
\text { Concrete tank roof slab } 14 \mathrm{ft} \text { below grade }\end{array}$ & $\begin{array}{l}49 \text { kips, or } 1.0 \mathrm{ksf} \\
0.96 \mathrm{ksf}\end{array}$ \\
\hline $241-A X-152$ & Pump/Diverter Pit conc. cover blocks at grade leve? & 224 kips, or \\
\hline $241-A Z-151$ & $\begin{array}{l}\text { Pump Pit conc. cover blocks at grade level } \\
\text { Concrete tank roof slab } 16 \mathrm{ft} \text { below grade }\end{array}$ & $\begin{array}{r}170 \text { kips, or } 3.9 \text { ksf } \\
62 \text { kips, or } 1.7 \mathrm{ksf} \\
\end{array}$ \\
\hline $241-A Z-154$ & Pump Pit conc. cover block at grade level & 191 kips, or $6.0 \mathrm{ksf}$ \\
\hline 241-EW-151 & Diversion Box conc. cover blocks at grade level & 97 kips, or $3.0 \mathrm{ksf}$ \\
\hline $241-5-304$ & Pump Pit conc. cover blocks at grade level & 51 kips, or $1.0 \mathrm{ksf}$ \\
\hline $\begin{array}{l}241-T X-302 C \\
241-U X-302 A\end{array}$ & $\begin{array}{l}\text { Pump Pit steel cover plate at grade level } \\
\text { Steel Tank } 26 \mathrm{ft} \text { below grade }\end{array}$ & $\begin{array}{l}7 \text { kips, or } 3.4 \text { ksf } \\
\text { Fails under soil dead loads }\end{array}$ \\
\hline $241-U-301 B$ & $\begin{array}{l}\text { Pump Pit steel cover plate at grade level } \\
\text { Concrete domed tank } 11 \mathrm{ft} \text { below grade }\end{array}$ & $\begin{array}{r}7 \text { kips, } \text { or } 3.4 \text { ksf } \\
2,689 \text { kips, } \text { or } 7.7 \text { ksf } \\
\end{array}$ \\
\hline 244-A & Pump Pit conc. cover blocks at grade level & 61 kips, or \\
\hline
\end{tabular}


Page 12

\begin{tabular}{|c|c|c|c|c|}
\hline $241-A-350$ & Pump Pit conc. cover blocks at grade level & 53 kips, & or & $1.2 \mathrm{ksf}$ \\
\hline 244-BX, TX, U & Pump Pit conc. cover blocks at grade level & 70 kips, & or & $1.3 \mathrm{ksf}$ \\
\hline $244-C R-003$ & Pump Pit conc. cover blocks at grade level & 53 kips, & or & $2.0 \mathrm{ksf}$ \\
\hline $244-S$ & Pump Pit conc. cover blocks at grade level & 31 kips, & or & $0.38 \mathrm{ksf}$ \\
\hline 200-Series SST & Concrete Tank roof slab $11 \mathrm{ft}$ below grade & 327 kips, & or & $1.04 \mathrm{ksf}$ \\
\hline
\end{tabular}




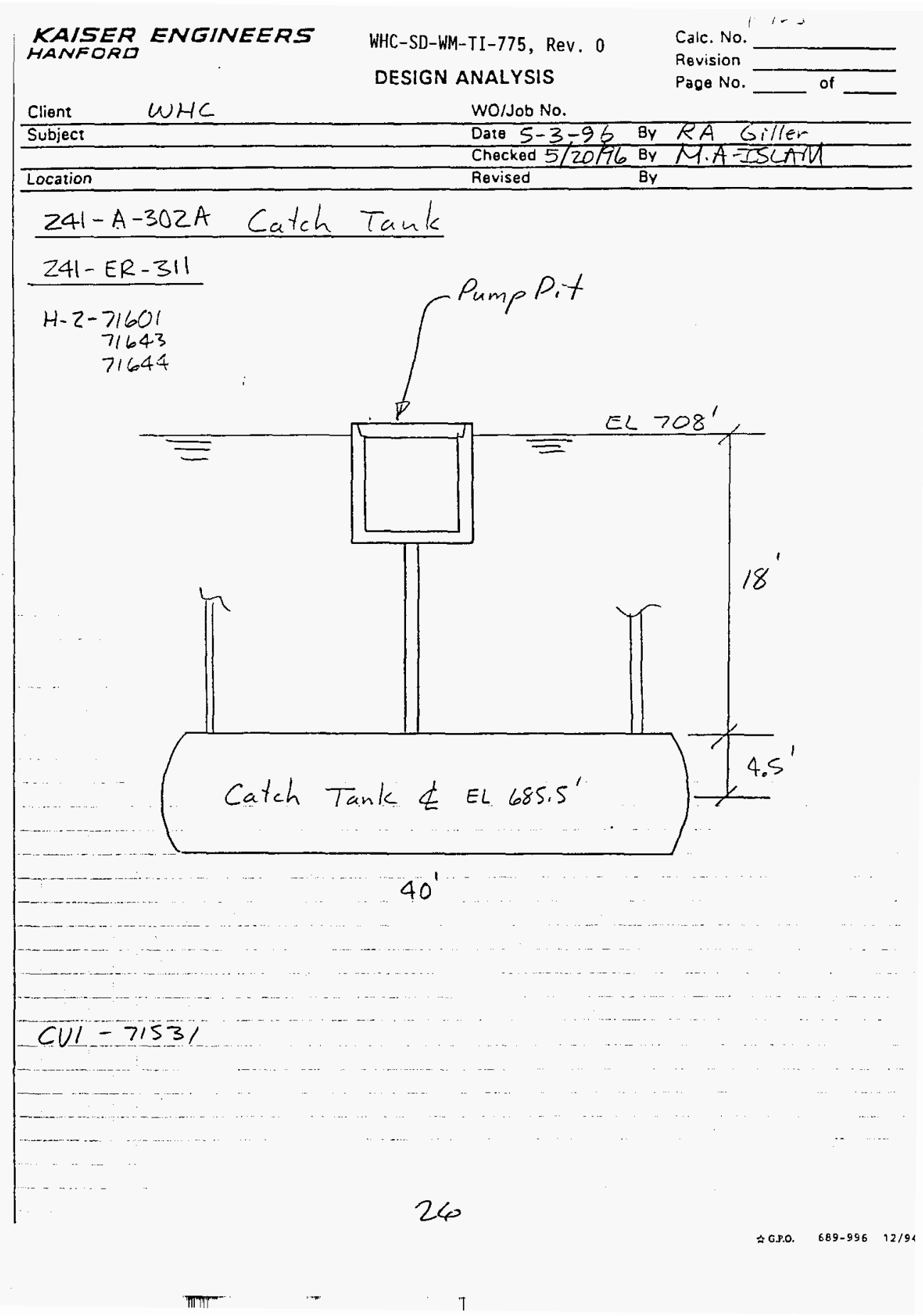


KAISER ENGINEERS HANFORD

\begin{tabular}{lrl} 
Client $\quad$ S & DESIGN ANA \\
\hline Subject & Location & Re \\
\hline $241-A-302 A \& 241-E R-311$
\end{tabular}

Capacity: (Rout fth Ed pg 263)

$$
\begin{aligned}
& M=\frac{W R k_{2}}{\pi} \\
& M=\frac{w\left(54^{\prime \prime}\right)(1,0)}{\pi}=17.2 \mathrm{~W} \\
& f_{b}=\frac{m}{5} \\
& 30000 \text { psi }=17.2 \mathrm{~W} / \mathrm{s} \\
& W=872 \mathrm{lb}
\end{aligned}
$$

Soil Dead Load:

$$
18^{\prime} \times 125 \text { pct }=22501 b>8721 b
$$

soil dead loads exceed tank allow able load :-

No. Good
Calc. No

Revision

Page No.

WOJJob No.

of

Date $5-10$

R.A Gilled

Catch Tank

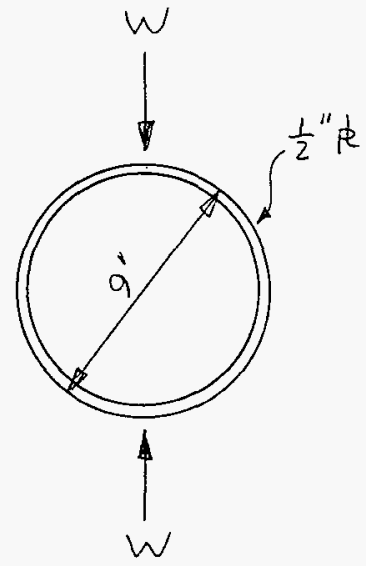

$$
\begin{aligned}
& A=\left(.5^{\prime \prime}\right)(.12)=6 \\
& I=(12)(.5)^{3} / 12=.125 \\
& S=12(.5)^{2} / 6=.5 \\
& \alpha=I / A R^{2} \\
& =.125 / 6.54^{2} \\
& =0.0 \\
& K_{2}=1-\alpha=1.0
\end{aligned}
$$

28

A GP. $\quad 689-996 \quad 12 / 9$

$\pi T \pi$

T 
KAISER ENGINEERS

WHC-SD-WM-TI-775, Rev. 0 Calc. No.

HANFORD
$\begin{gathered}\text { WHC-SD-WM-TI-775, Rev. 0 } \\ \text { DESIGN ANALYSIS }\end{gathered}$

241-A-417 Surface Condenser Facility
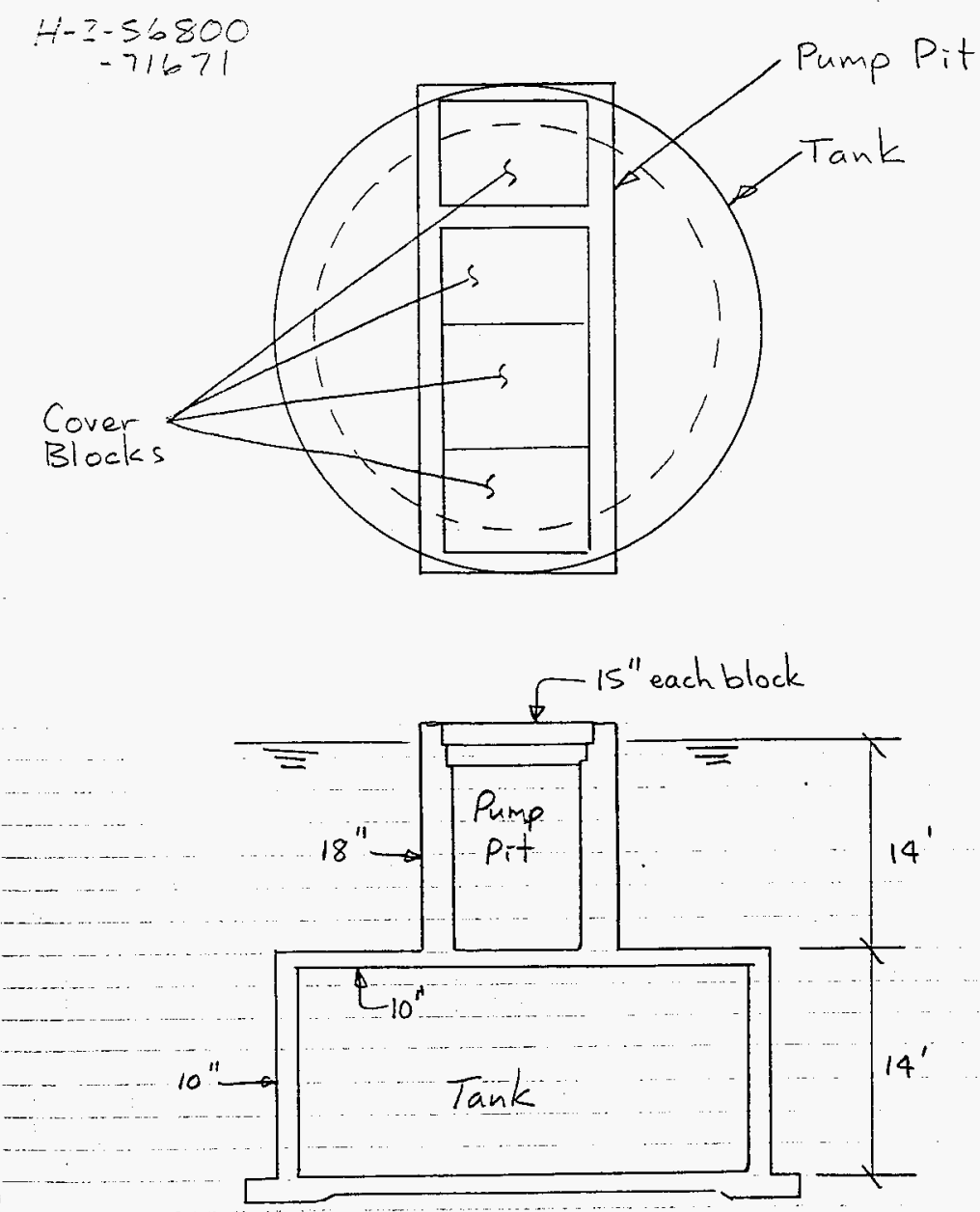

29

G.P.O. 


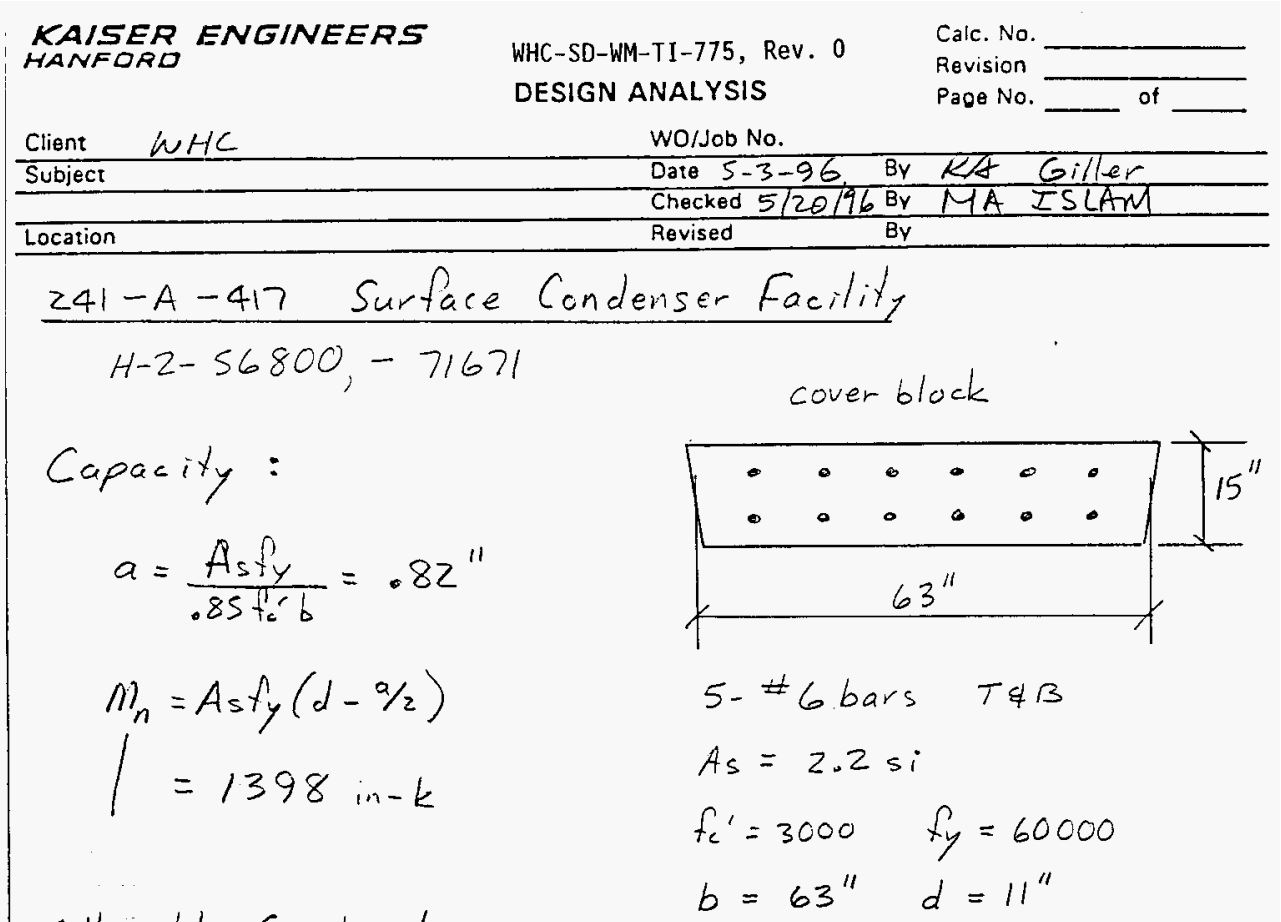

Allowable Conc load:

$$
\begin{aligned}
& m_{n}>m_{n}=\frac{\omega l^{2}}{8}+\frac{P l}{4} \\
& 1398=\left[\frac{188(9.25)^{2}}{8}+\frac{p(9.25)}{4}\right] \frac{12}{1000} \omega=188 \text { psf } \quad h=9.25^{\prime} \\
& 116500=2011+2.3 P \\
& \begin{array}{l}
P=49 \quad \text { kips } \\
w=1.0 \mathrm{ksf}
\end{array} \\
& 27 f_{c}^{\prime} b d=76 \text { kip } \\
& 0 . K
\end{aligned}
$$

30

G.P.O. 


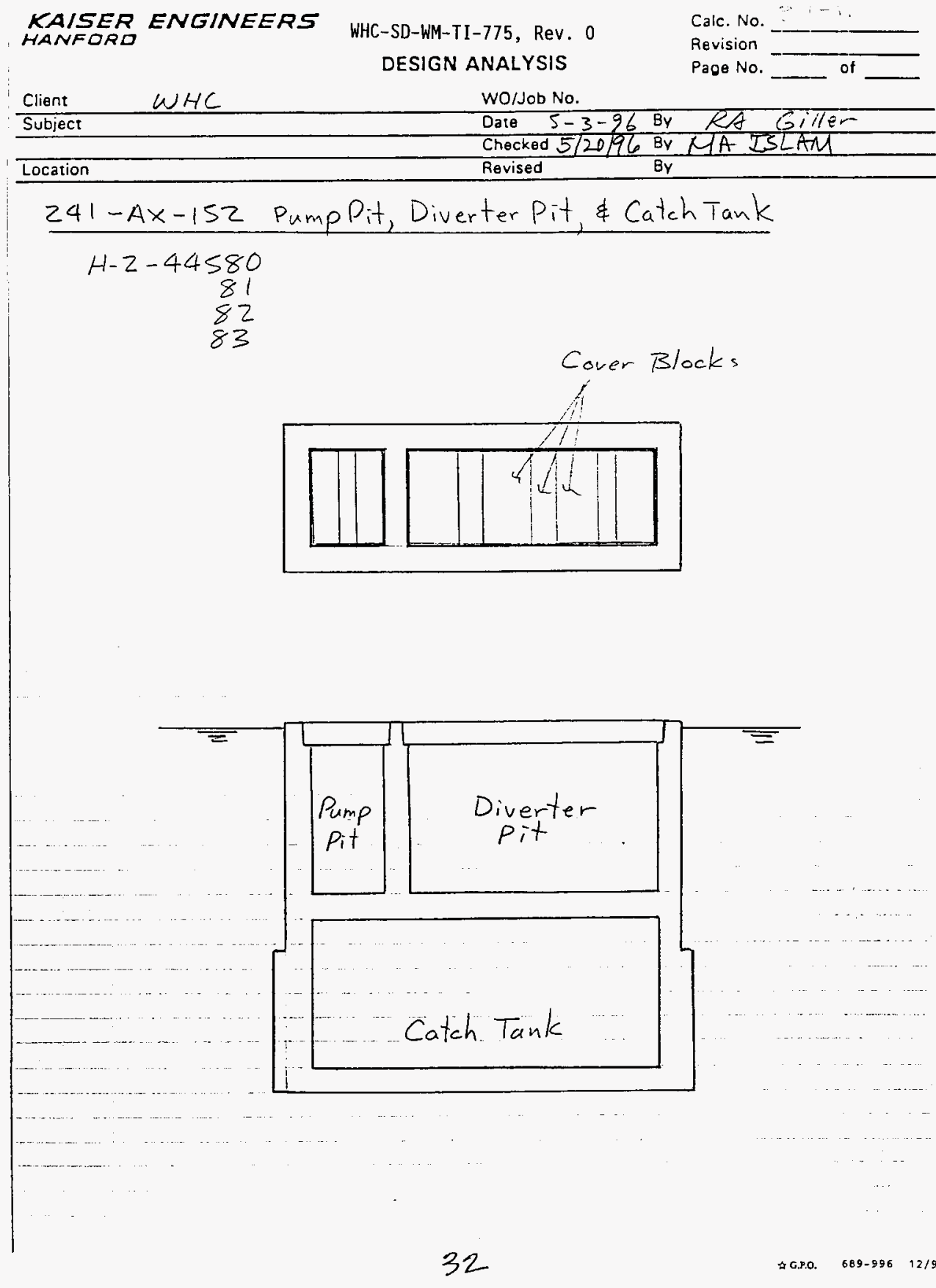




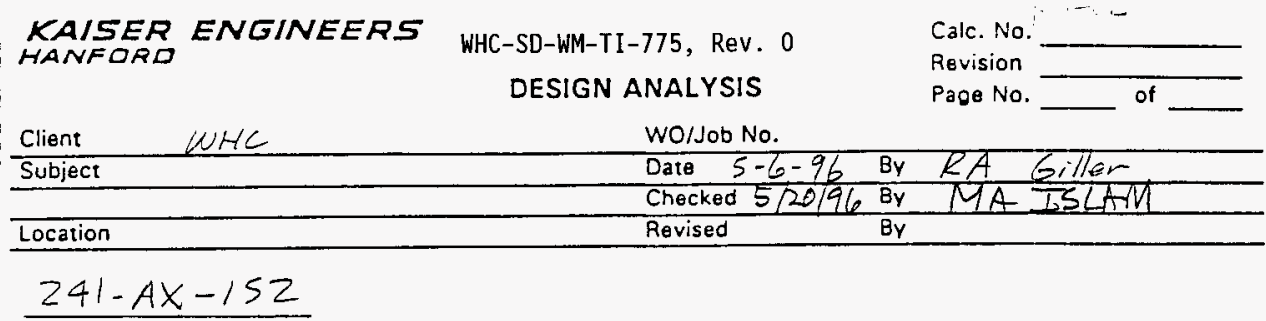

Capacity:

$$
\begin{aligned}
& a=\frac{A_{s} F_{y}}{.85 f_{c}^{\prime} b}=.863 \\
& m_{n}=A_{s} F_{y}(d-a / 2) \\
& =4475 \mathrm{in}-k
\end{aligned}
$$

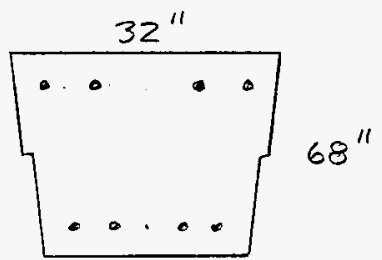

4- ${ }^{\# 6} \quad T \notin B$

$A_{s}=1.76$

$f_{c}^{\prime}=3000 \quad F y=40000$

$b=32^{\prime \prime} \quad d=64^{\prime \prime}$

Allowable cone. Load:

$$
\begin{aligned}
M_{n}>M_{n} & =\frac{w l^{2}}{8}+\frac{p l}{4} & w & =850 \text { psf } \\
4475 & =\left[\frac{850(6)^{2}}{8}+\frac{P(6)}{4}\right] \frac{12}{1000} & l & =6^{\prime}
\end{aligned}
$$$$
372917=3825+1.5 P
$$$$
P=246^{K}
$$

Check Shear:

$$
2 \sqrt{f_{c}^{\prime}} b d^{\prime}=224^{k}
$$

$0 . K$

$$
\begin{array}{r}
\text { Reduce } P=224 \mathrm{~K} \\
w=14.9 \\
33
\end{array}
$$

GP. $\quad 689-996 \quad 12 / 91$ 
$\underset{\text { HANFORD }}{\text { KAISER ENGINEERS }}$

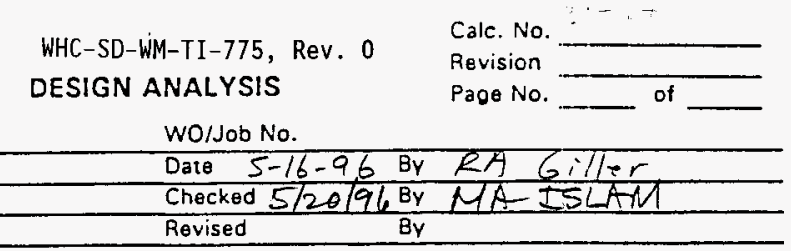

241-AZ- IS! Cover Block

Capacity :

$$
\begin{aligned}
& a=\frac{A_{s} F_{y}}{.85 f_{i b} b}=.646 \\
& \left.M_{n}=A_{s} F_{y}(d-a) 2\right) \\
& 1=3343 \mathrm{in}-k
\end{aligned}
$$

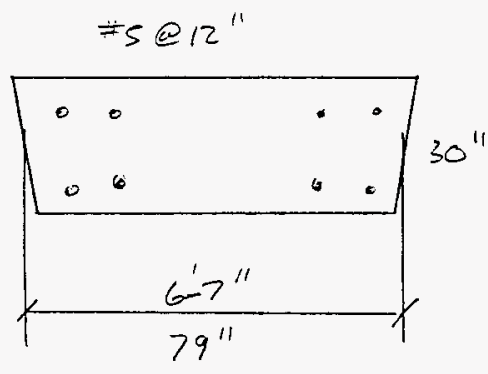

$$
\begin{aligned}
& 7-\# 5 \text { bars } \\
& A_{s}=2.17 \\
& f_{c}^{\prime}=3000 \quad F_{y}=6000 \\
& d=26^{\prime \prime} \quad l=6.5^{\prime}
\end{aligned}
$$

$$
\begin{gathered}
m_{n}>m_{n}=\frac{w l^{2}}{8}+\frac{p l}{4} \\
3343=\left[\frac{375(6.5)^{2}}{8}+\frac{p(6.5)}{4}\right] \frac{12}{1000}
\end{gathered}
$$

Check Shear

$$
2 \sqrt{f_{c}^{\prime}} b d=225 \mathrm{~K}
$$$$
0 . K
$$

35 
KAISER ENGINEERS
HANFORD

WHC-SD-WM-TI-775, Rev. 0

DESIGN ANALYSIS

WO/Job No.

Calk. No. $:-15$

Revision

Page No.

of

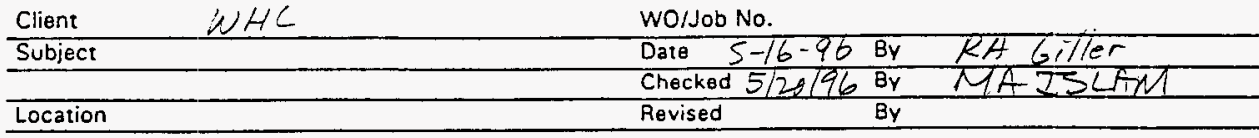

241-AZ-151 Catch Tank

Capacity:

$$
\begin{aligned}
& a_{\text {top }}=\frac{(.31)(60)}{.85(3) 12}=.608^{\prime \prime} \\
& m_{n}=A_{s} F y\left(d-\frac{0}{T_{o p}}\right)=171 \mathrm{in}-\mathrm{k}
\end{aligned}
$$

$a_{\text {bot }} \frac{(.2)(60)}{.85(3)(12)}=.392^{\prime \prime}$

$$
M_{n \rightarrow t}=A_{s} F_{y}(d-a / 2)=111 \mathrm{in}-k
$$

Allowable Dist. Load:

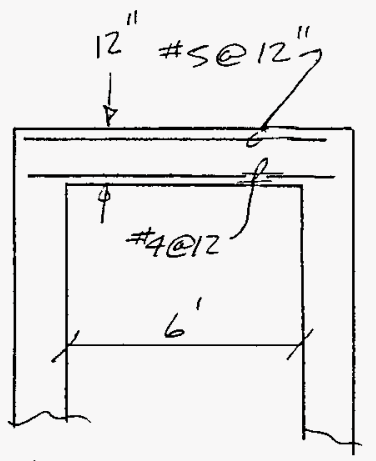

$$
\begin{aligned}
& A_{S_{T O P}}=.31 \\
& A_{s_{\text {bot }}}=.2 \\
& f_{c}^{\prime}=3000 \quad f_{y}=60000 \\
& d=9.5^{\prime \prime} \quad l=6^{\prime} \\
& \begin{aligned}
w & =150+16^{\prime} \times 125 \\
& =2150
\end{aligned}
\end{aligned}
$$

$$
M_{n}>M_{u}=\frac{w \ell^{2}}{12}+\frac{P l}{8} \text { (Fixed Ends) }
$$$$
171=\left[\frac{2150(6)^{2}}{12}+\frac{P(6)}{8}\right] \frac{12}{1000}
$$

$$
14250=6450+.75 P
$$

check shear

$$
10400 \# / \text { uni width }=P \quad 2 \sqrt{f_{c}^{\prime}} b d=74928=
$$

36

A G.P.O. 
KAISER ENGINEERS
HANFORD

WHC-SD-WM-TI-775, Rev. 0

DESIGN ANALYSIS
Cate. No.

Revision

Page No.
$0.1-17$

of

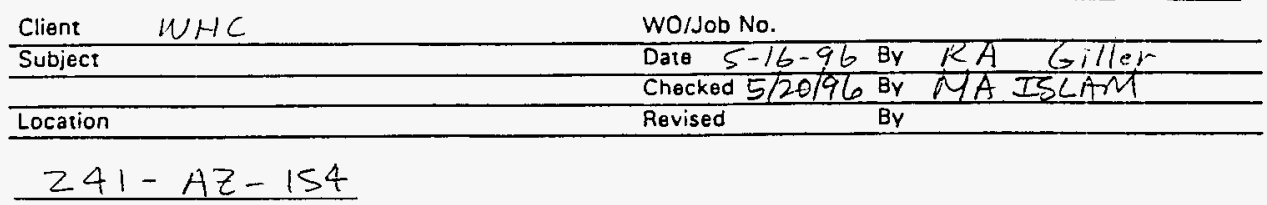

$\# 5 e 12 "$

Capacity:

$$
\begin{aligned}
& a=\frac{A F_{y}}{.85 \hat{f}_{i} b}=.762^{\prime \prime} \\
& M_{n}=A_{s} F_{y}(d-a / 2) \\
& =3335 \mathrm{ink} k
\end{aligned}
$$

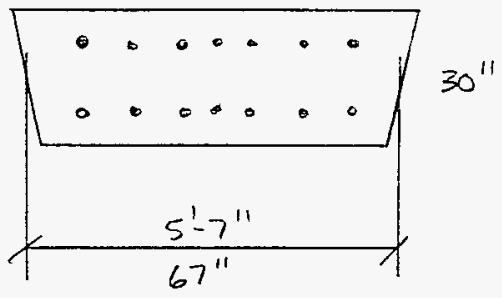

7.- 5 bars

$A_{s}=2.17$

$f_{c}^{\prime}=3000 \quad F_{y}=60000$

$m_{n}>m_{n}=\frac{\omega l^{2}}{8}+\frac{\rho l}{4}$

$w=375$ psf

$3335=\left[\frac{375(5.5)^{2}}{8}+\frac{P(5.5)}{4}\right] \frac{12}{1000}$

$d=26^{\prime \prime} \quad l=5.5$

$277917=1418+1.375 P$

Check Shear

$201 \quad$ kips $=\ldots P$

$2 \sqrt{f_{c}^{\prime}} b d=191$ kips

Reduce P $=191$ kips

$\omega=6 \mathrm{ksf}$

$0 . K$

38

G.P.O. $689-996 \quad 12 / 94$ 
KAISER ENGINEERS HANFOAD
WHC-SD-WM-TI-775, Rev. 0

DESIGN ANALYSIS

Calc. No. $[P, 1-1\}$

Revision

Paoe No. ot WOJjob No.

\section{Client}

Date 5-7-9
Checked $5 / 20 / 412$ By Revised BV

Subject

Location

Vent

Station

$$
\begin{aligned}
& \text { 241-EW-151 Vent Station Diversion Box } \\
& H-Z-43148 \\
& 53 \\
& 54
\end{aligned}
$$

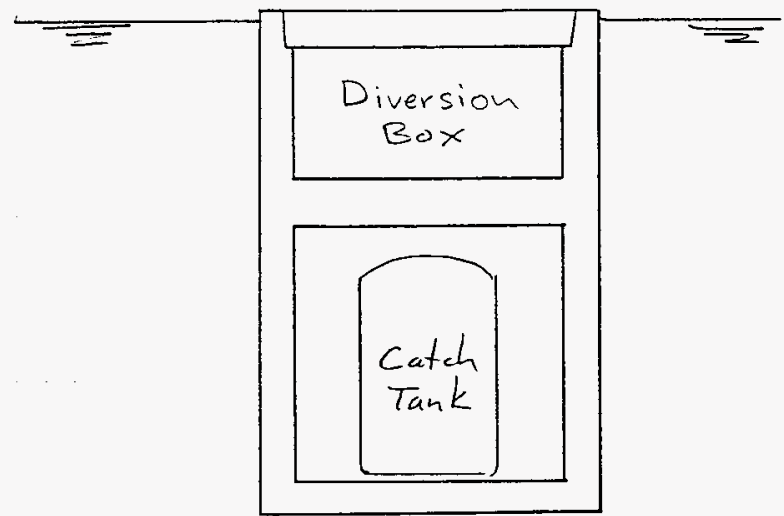


KAISER ENGINEERS
HANFORD

$\frac{\text { Client }}{\text { Subject }}$ tHC
Location
$241-E W-151$

Capacity:

$$
\begin{aligned}
a & =\frac{A_{s} F_{y}}{.85 f_{i}^{\prime} b}=.812 \\
m_{n} & =A_{s} F_{y}(d-a / 2) \\
& =2069 \mathrm{~m} \cdot k
\end{aligned}
$$

WHC-SD-WM-TI-775, Rev. 0

DESIGN ANALYSIS
Talc. No.

Revision

Page No.

$$
\therefore-a
$$

WO/Job No.

Date 5-7-9,6 By RA Wilier

Checked $5 / 20 \% 96$ By MA ISLIMT

Cover Block

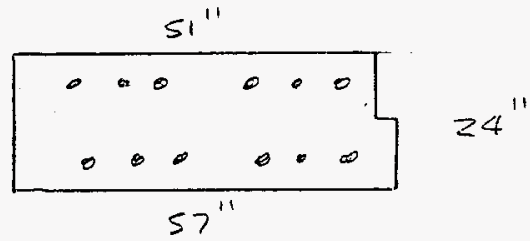

$6-\# 6$

As $=2.64$

$f_{c}^{\prime}=3000 \quad F_{y}=40000$

$b=51^{\prime \prime} \quad d=20^{\prime \prime}$

Concentrated Load:

$$
\begin{gathered}
M_{n}>M_{n}=\frac{w l^{2}}{8}+\frac{P l}{4} \\
2069=\left[\frac{300(7)^{2}}{8}+\frac{P(7)}{4}\right] \frac{12}{1000} \\
172417=1838+1.75 P \\
97 \quad k i p=P \\
3 k s f=\omega
\end{gathered}
$$$$
w=300 p s f
$$$$
\ell=7^{\prime} \text {. }
$$

Shear Shear:

$$
\frac{2 \sqrt{f_{c}^{\prime} b d}}{1000}=111.7 \text { kips }
$$

40

A. GP.

$689-996$

$12 / 9$ 
KAISER ENGINEERS

WHC-SD-WM-1775, Rev 0 Call. No. $P 1-=0$

DESIGN ANALYSIS

Revision

Page No.

of

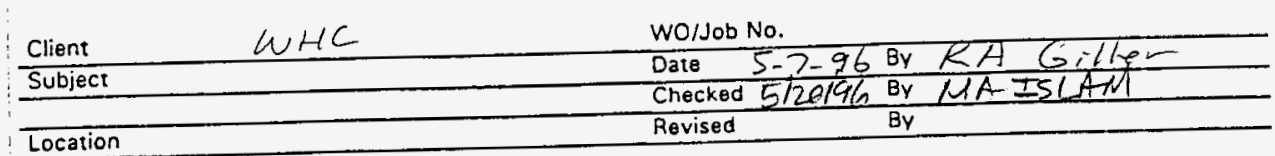

241-5-304 Catch Tank

$H-2-85019-36$

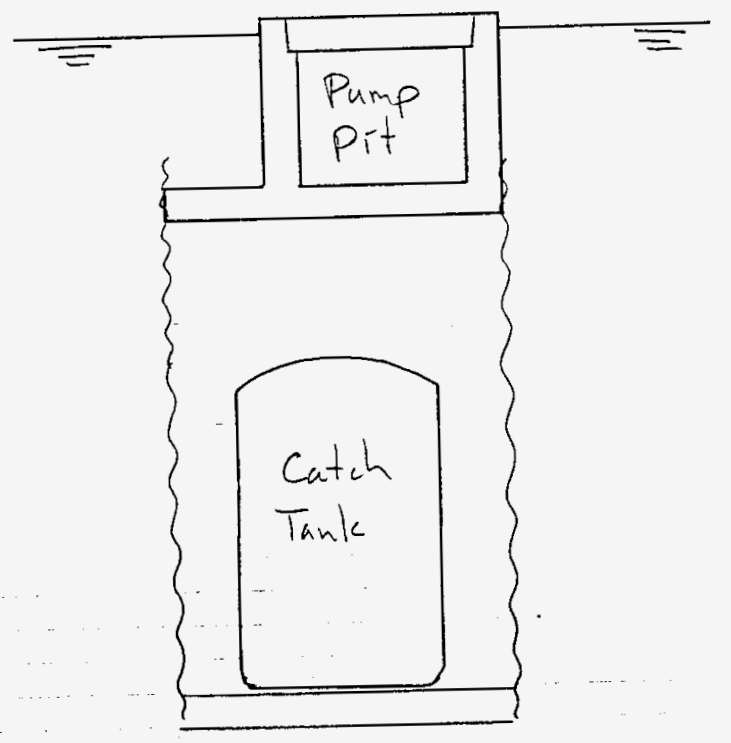

41

200.9. $699-996 \quad 12 / 9$.

$\pi T=$

7 
KAISER ENGINEERS

HANFORD
WHC-SD-WM-TI-775, Rev. 0

DESIGN ANALYSIS
Talc. No.

Revision

Page No. of WO/Job No.

Client $\quad 104 \mathrm{C}$

Location

241-5-304 Catch Tank

Capacity:

$$
\begin{aligned}
a & =\frac{A_{s} F_{y}}{.85 f_{c}^{\prime} b}=.862 \\
M_{n} & =A_{s} F_{y}(d-a / 2) \\
1 & =2067 \mathrm{in} .16
\end{aligned}
$$

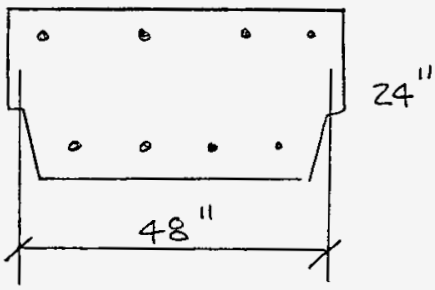

4- \#6 bars

$$
\begin{aligned}
& A_{s}=1.76 \\
& f_{c}^{\prime}=3000 \quad F_{y}=60000 \\
& b=48 \quad d=20
\end{aligned}
$$

Concentrated Loads:

$$
\begin{array}{ll}
M_{n}>M_{n}=\frac{w l^{2}}{8}+\frac{P l}{4} & \\
2067=\left[\frac{300(13)^{2}}{8}+\frac{P(13)}{4}\right] \frac{12}{1000} & w=300 \text { ps } \\
172250=6337+3.25 P & l=13
\end{array}
$$

51$$
\text { kips }=P
$$$$
\text { 1.0. ks } f=w
$$

Check Shear:

$$
\frac{2 \sqrt{f_{c}^{\prime} b d}}{1000}=\frac{105 \mathrm{kips}}{0.1}
$$

42

מ G.P.O. $689-996 \quad 12 / 9$

Hill. $^{-1}$

"T 
KAISER ENGINEERS

WHC-SD-WM-TI-775, Rev. 0

Calf. No. ? :-2-

DESIGN ANALYSIS

Revision

Page No.

of

\begin{tabular}{|ll} 
Client WHC & wo/Job No. \\
\hline Subject & Date $5-6-96$ By RA Killer \\
\hline Location & Checked E/20/91/ By MA ISLAM \\
\hline
\end{tabular}

241-TX-302C. Pump Pit, Catch Tank

241-Ux-302A, Pump Pit, Catch Tank

$$
\begin{array}{r}
H-2-71643 \\
660 \\
665
\end{array}
$$$$
H-2-833
$$$$
836
$$
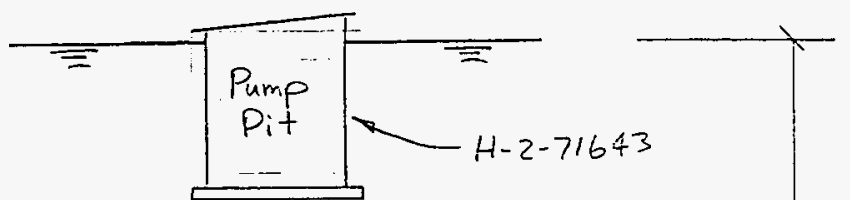

Catch Tank

$30.5^{\prime}$

$9^{\prime} \phi, 36^{\prime}$ long, $1 / 2$ " thick

$S S T-18-8 C$

43

G.P.O. $689-996 \quad 12 / 9$ 


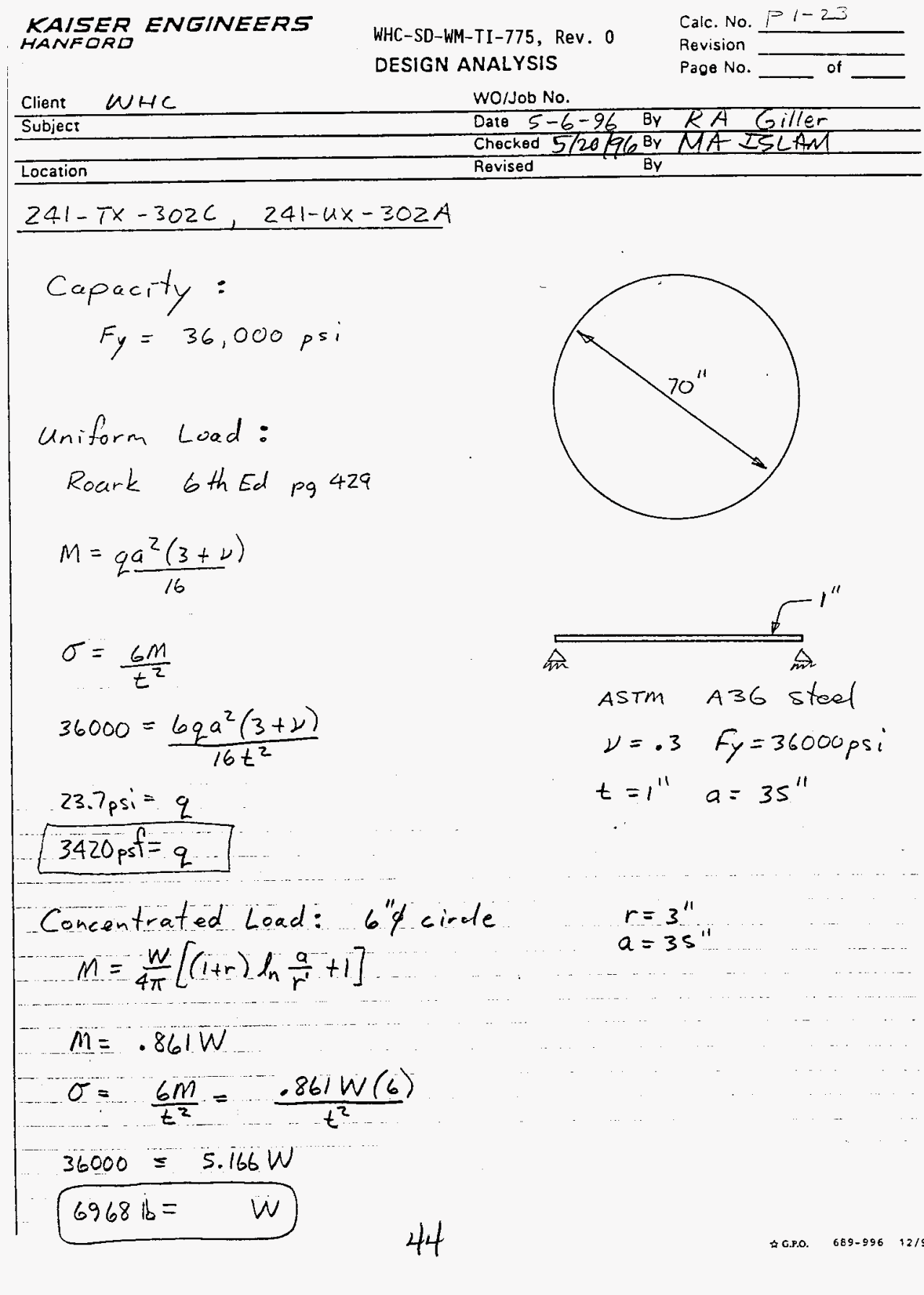




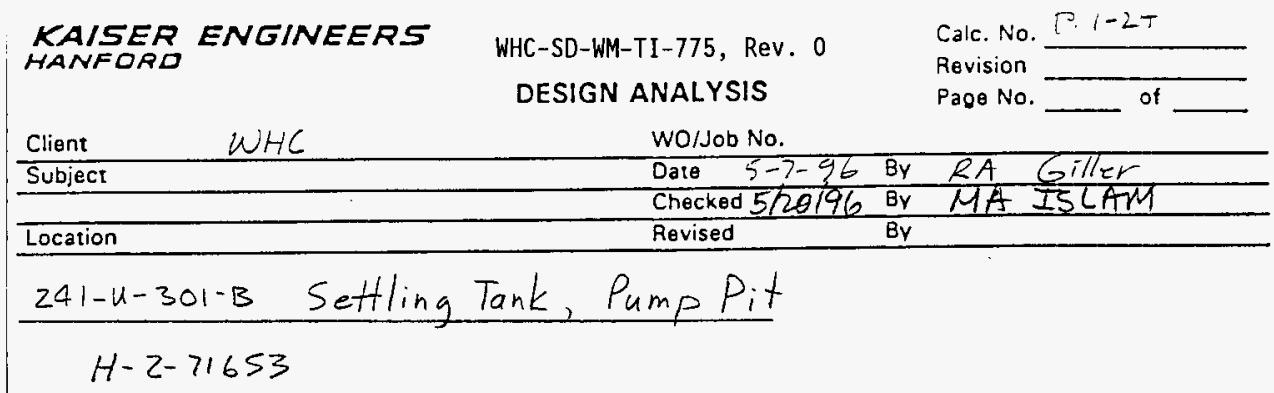

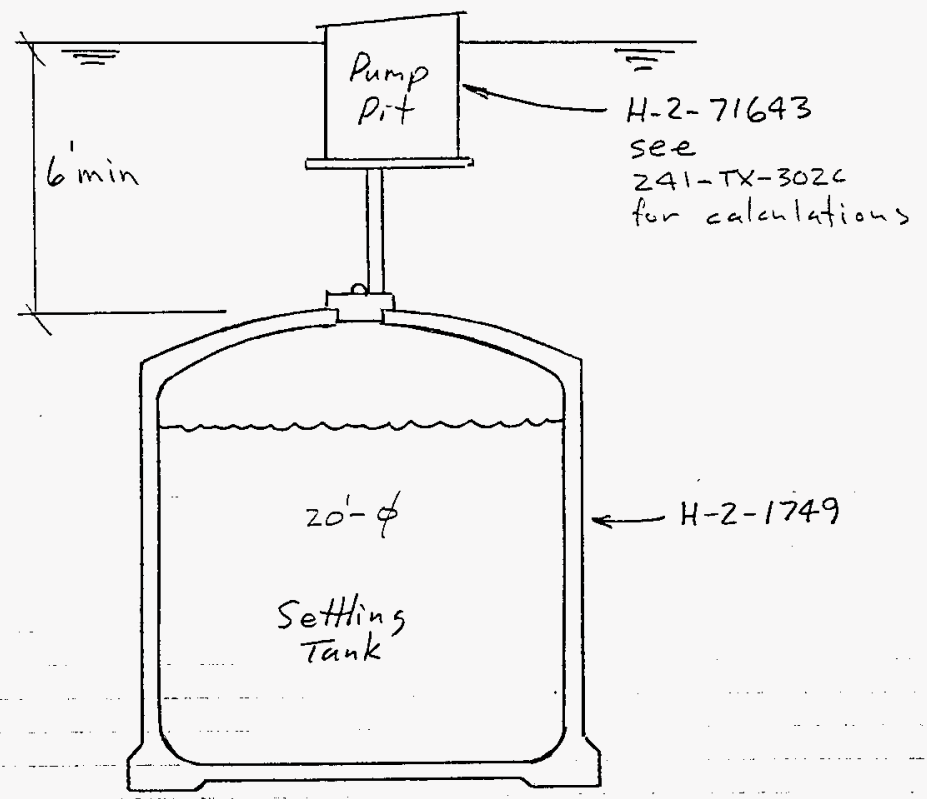

45

G.P.O. 689-996

$12 / 9$ 
KAISER ENGINEERS

HANFORD

-

WHO

Location
WHC-SD-WM-TI-775, Rev. 0

DESIGN ANALYSIS
Cali. No., $1-25$

Revision

Page No. of

WO/Job No.

Date $5-7-96$ By RA Gilled

Checked $5 / 20196$ BY NA ISLAM

Revised

BY

241-4-301-B Settling Tank

(Roark, fth Ed, pg 547, Fig sb) $\pm 4 @ 6$ "0.C7

Concentrated Load $P$.

Edge moment $M_{0}$

$$
\begin{aligned}
& m_{0}=-B_{2} \frac{P}{4 \pi} \\
& \alpha=2\left[\frac{3\left(1-\nu^{2}\right) h^{2}}{t^{2}}\right]^{1 / 4}=7.7
\end{aligned}
$$

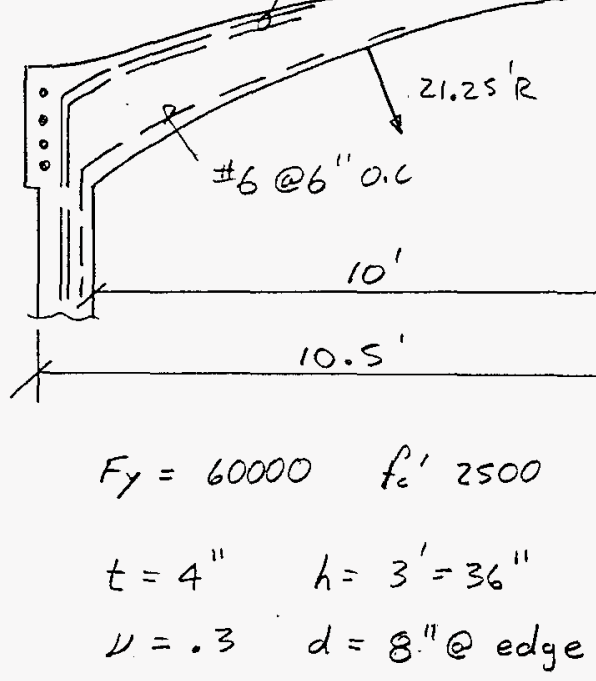

$$
\begin{aligned}
& B_{I}=-.07 @ \alpha=7.7 \\
& m_{0}=-.0056 P \propto
\end{aligned}
$$

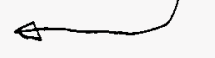$$
a=\frac{A s F_{y}}{.85 f_{c}^{\prime} b}=\frac{.4(60)}{.85(2.5)(12)}=.941
$$$$
M_{n}=A_{s} F_{y}(d-\%)=\frac{(.4)(60000)\left(8-\frac{.941}{2}\right)}{12^{11}}=15059 \mathrm{~m}-16 / \mathrm{in}
$$$$
m_{n}>M_{0}
$$$$
15059=.0056 \cdot P
$$

$$
2,689,107 \mathrm{lb}=P
$$

$2,689 \quad k_{i p}=P \quad$ uniform Load $=\frac{P}{\pi R^{2}}=7763$ sst

46

A G.P.0. $689-996 \quad 12 / 94$

il i li

I 


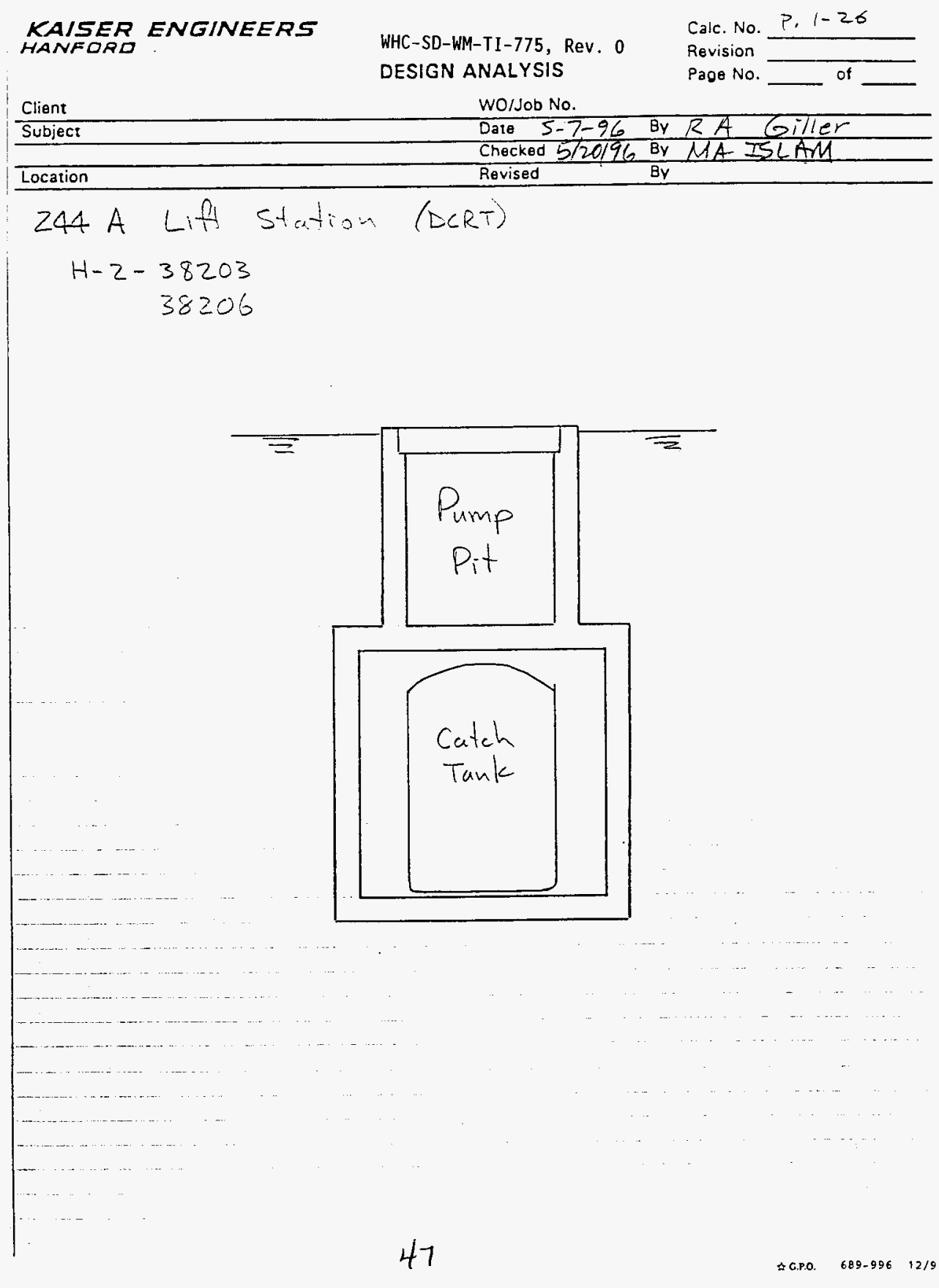




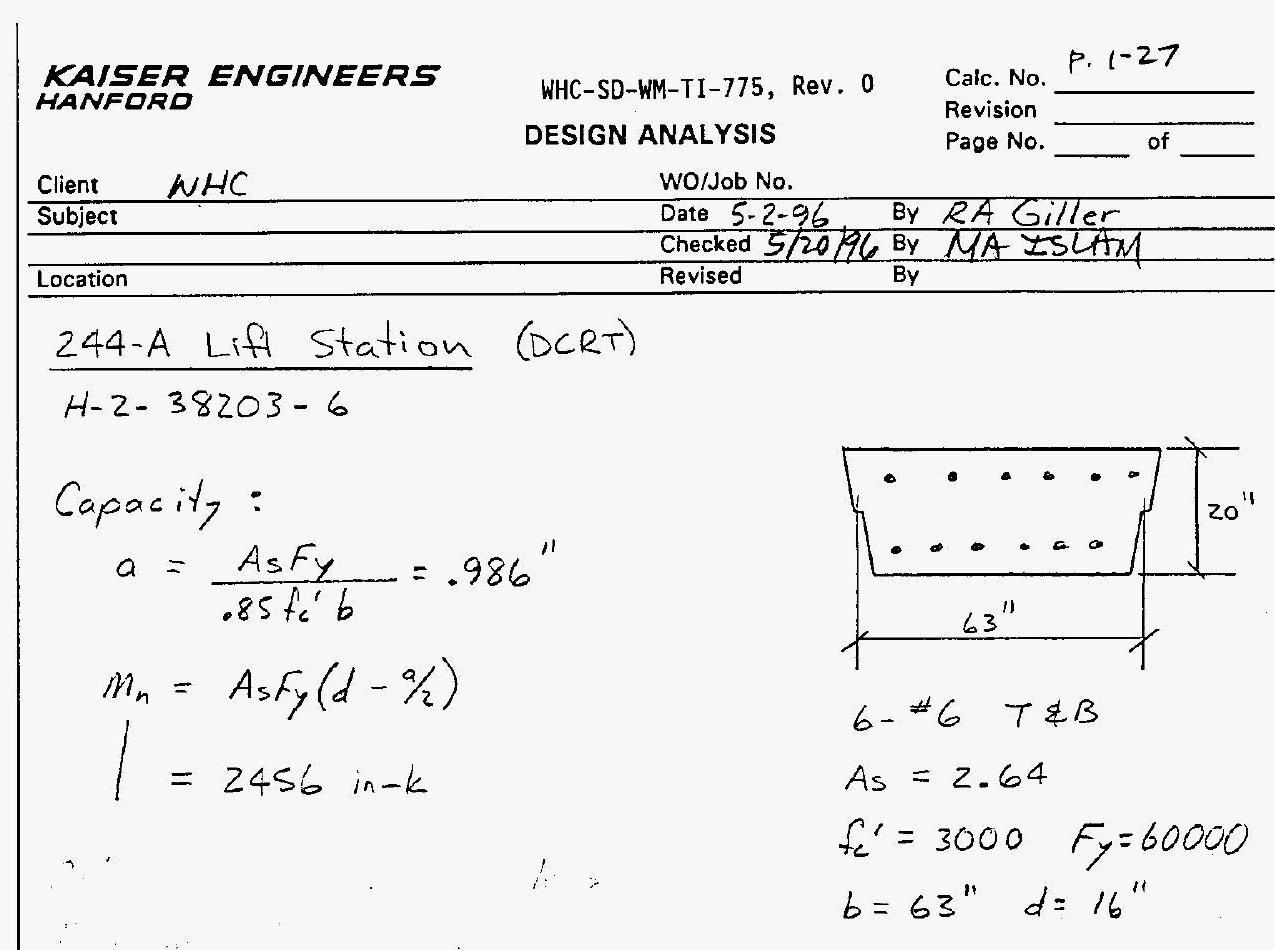

Find allowable cone load:

$$
\begin{aligned}
& m_{n}>m_{u}=1.0 \frac{w l^{2}}{8}+1.0 \frac{P l}{4} \\
& 2456=\left[\frac{250(13)^{2}}{8}+\frac{P(13)}{4}\right] \frac{12}{1000} \\
& 204667=5281+3.25 P
\end{aligned}
$$

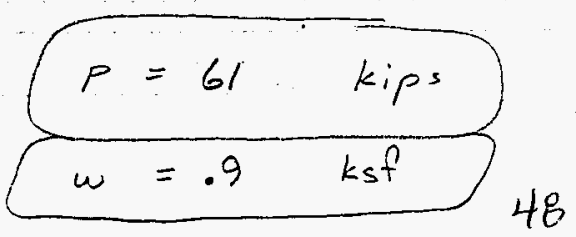

$$
\begin{aligned}
& w=250 \text { psf } \\
& l=13
\end{aligned}
$$

Check Shear:

$$
\begin{aligned}
& \frac{2 \sqrt{f_{c}^{\prime}} b d}{1000}=110 \mathrm{kips} \\
& 0 . K
\end{aligned}
$$

$54-4300-037$ KEH-0037.00 (06/92) 


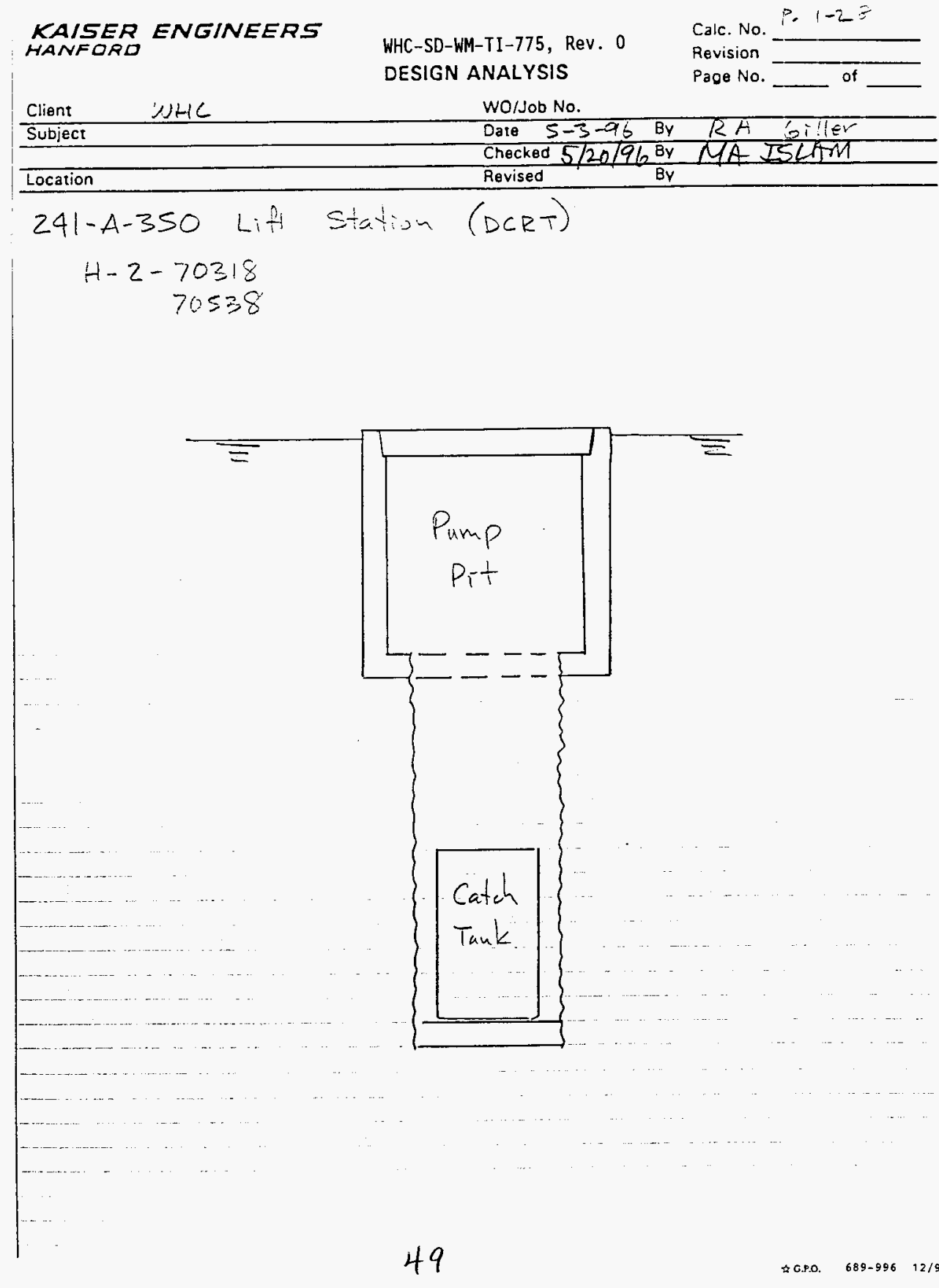


KAISER ENGINEERS HANFORO
WHC-SD-WM-TI-775, Rev. 0

DESIGN ANALYSIS
Calc. No.

Revision

Page No. of WO/Job No.

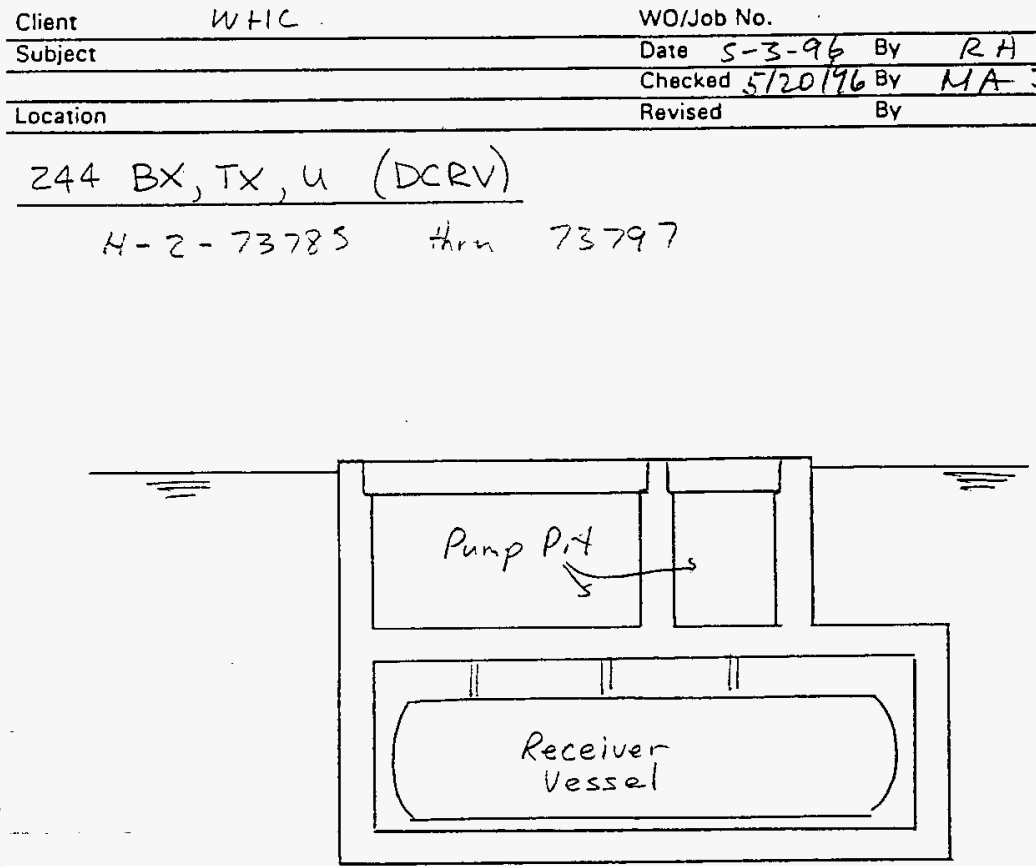




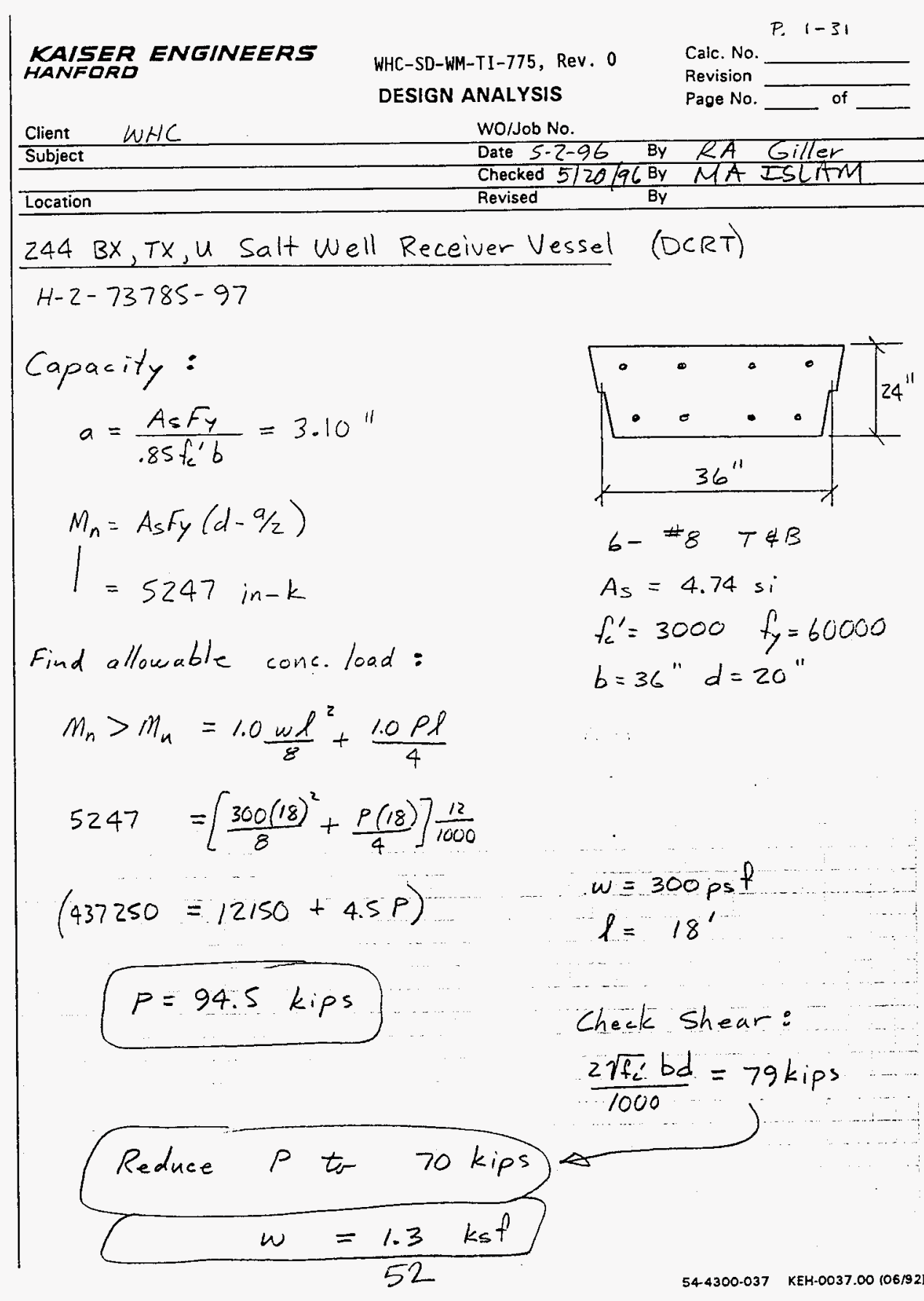


KAISER ENGINEERS HANFOAD
WHC-SD-WM-TI-775, Rev. 0

DESIGN ANALYSIS
Calc. No.

Revision

Page No.
Woljob No.

Date $5-2-96$ By $K A$ Giller Checked $5 / 2019 l_{2}{ }^{B Y}$ MA ISLATM

$$
\begin{array}{r}
H-2-415 \geq 0 \\
41982 \\
41983 \\
41889
\end{array}
$$
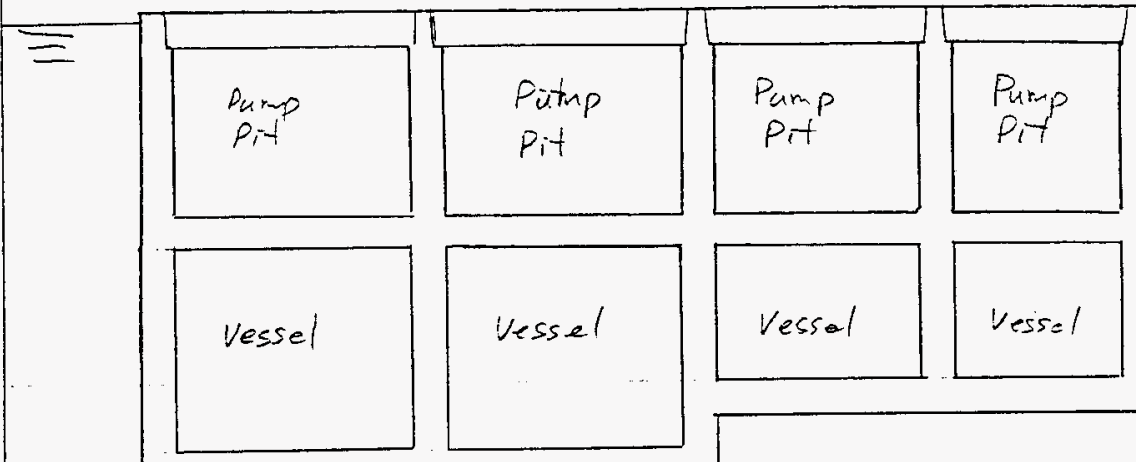
$\underset{\text { KANFISER ENGINEERS }}{\text { HANG }}$

WHC-SD-WM-TI-775, Rev. 0

DESIGN ANALYSIS
Cali. No.

Revision

Page No. to. $1-33$

WO/Job No.

Date $5-2-9,6$ By $R A$ Gilled Checked $5 / 20196$ By MA ISLAM Revised

$$
\text { By }
$$

244-CR Process Tank Vault (OCRT)

$$
\begin{array}{r}
H-2-41530 \\
41982 \\
41983 \\
41889
\end{array}
$$

Capacity:

$$
\begin{aligned}
a & =\frac{A_{s} F_{y}}{.85 f_{c}^{\prime} b}=.746^{\prime \prime} \\
M_{n} & =A_{s} F_{y}(d-9 / 2) \\
& =1407 \mathrm{in}-k
\end{aligned}
$$

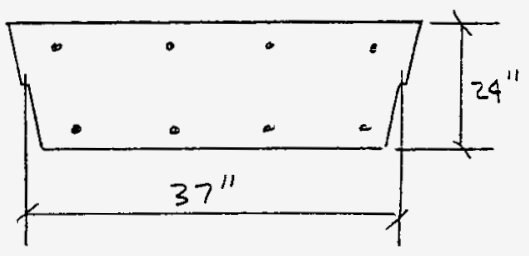

$4{ }^{*} 6$ bars $T \& B$

$A_{s}=1.76 \mathrm{si}$

$f_{c}^{\prime}=3000 \quad f_{y}=40,000 \mathrm{psi}$

$b=37^{\prime \prime} d=20^{\prime \prime}$

Allowable Conc- Load:

$$
\begin{aligned}
& M_{n}>M_{u}=\frac{10 \omega \ell^{2}}{8}+\frac{1.0 P l}{4} \\
& 1407=\left[\frac{300(8.6)^{2}}{8}+\frac{p(8.6)}{4}\right] \frac{12}{1000} \\
& (117250=2774+2.15 P) \\
& P=53 \text { kips } \\
& w=2 \text { ks }
\end{aligned}
$$

$$
\begin{aligned}
& w=300 p s f \\
& \ell=8.6^{\prime}
\end{aligned}
$$

Check Shear:

$$
\frac{2 \sqrt{f_{c}^{\prime} b d}}{1000}=81 \text { kips }
$$

$0, K$

54

$54-4300-037$ KEH-0037.00 (06/92)

"Tl'

7 


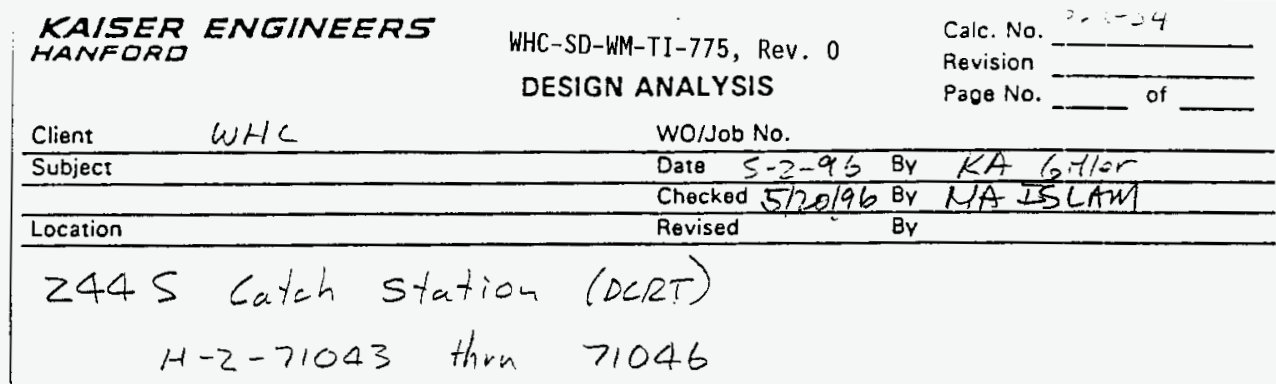

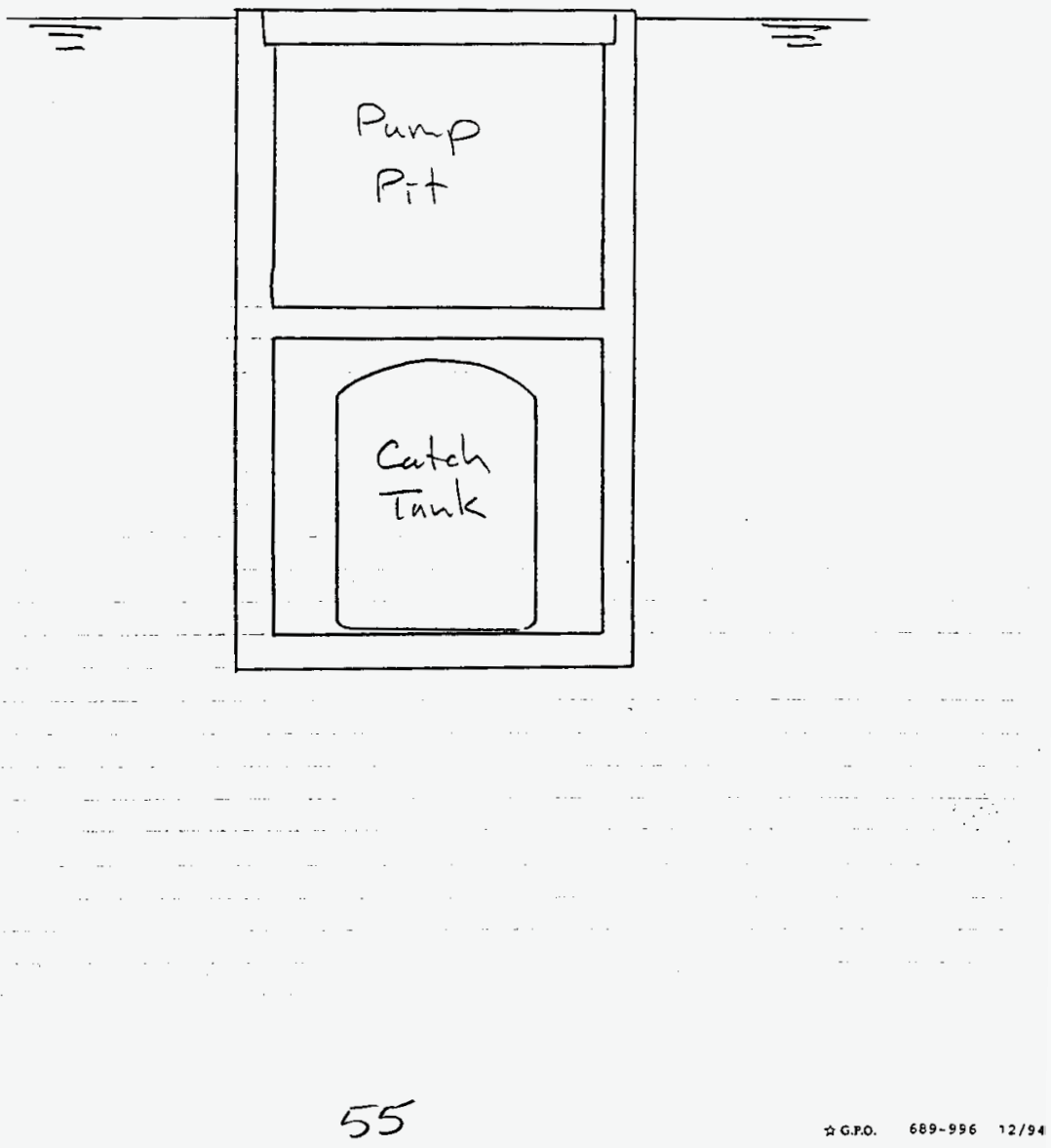




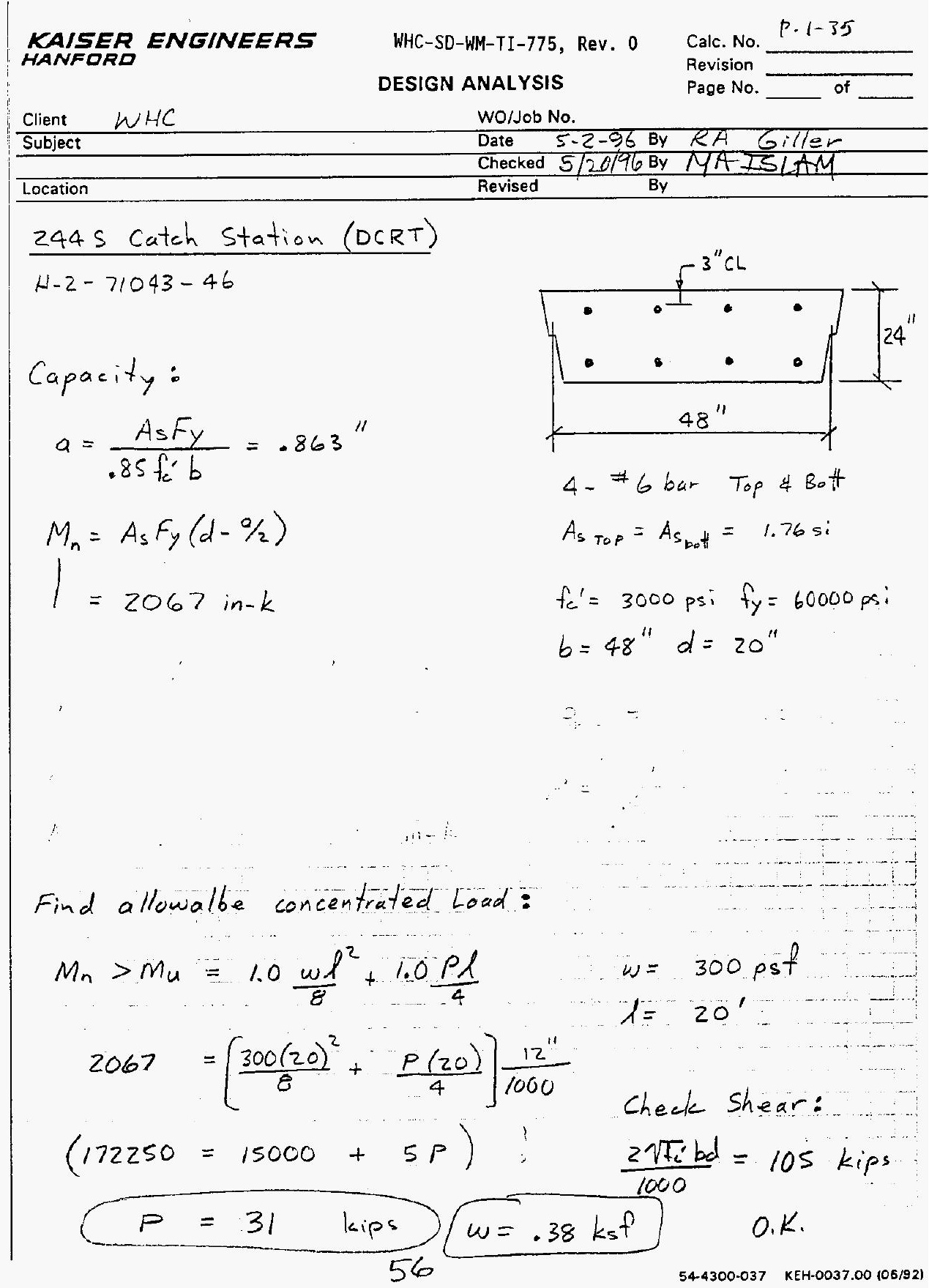




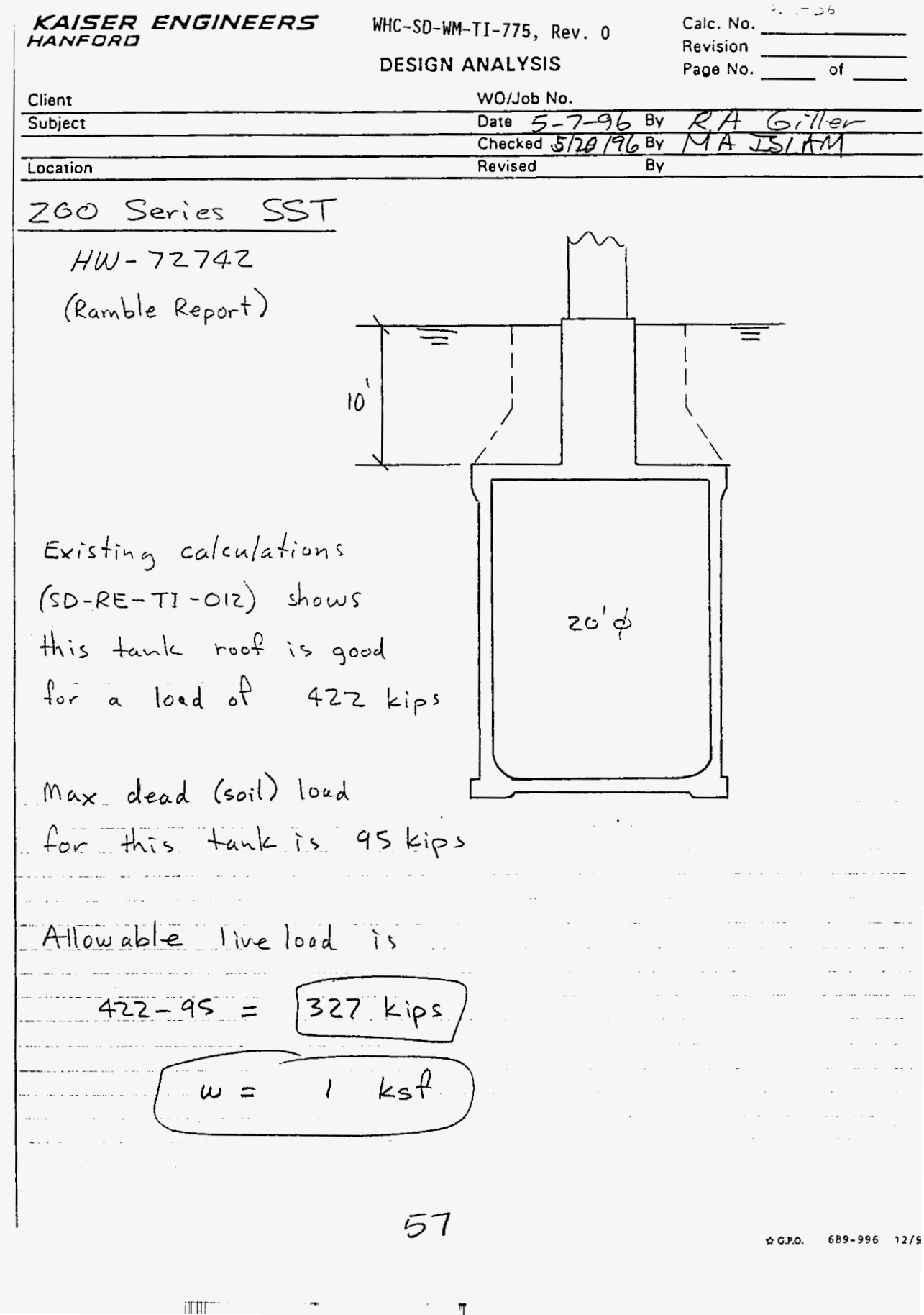


WHC-SD-WM-TI-775, Rev. 0

\author{
Appendix 2 \\ Calculations for Impact Energy from Dropped Equipment
}

58 
The effect of the impact load on the integrity of the containment for the tanks in the DCRTs, Catch Stations, and 200 Series SST was evaluated. The impact load may occur from the falling equipment anywhere on the tanks during the postulated accident scenarios. The following impact load conditions were evaluated:

A. Impact energy required to perforate the cover block for the tank in DCRTs and the Catch Stations.

B. Impact energy required to cause a bending failure in the cover block or in the roof when impact is associated with a non-rigid surface (cover block, concrete pit, riser etc.).

C. Same as in B. except when impact is associated with a yielding surface (ground).

The perforation or the bending failure in the cover block or in the roof will lead to develop an opening in the containment for the tanks in DCRTs, Catch Stations, and 200 Series SSTs.

The impact response of structures is characterized by intense dynamic stresses that produce crushing, cratering, shear failure, and tensile fractures in highly nonhomogeneous materials. Because of the complex nature of this response, detailed analyses by means of computational mechanics have not been developed sufficientiy to apply in the design of the structures to sustain impact.

This evaluation determined the capacity of the cover block and the roof of the tank vault to resist perforation and fracture. The weight and shape of the falling equipment were assumed to be 20,000 pounds and 2 feet diameter respectively. These data along with other assumed values for the concrete, reinforcement, and soil were used throughout the evaluations. For the evaluation of the perforation, 20-in thick cover block was used. This thickness was smallest of all the cover blocks in DCRTs and Catch Stations. Because 200 Series SSTs do not have cover blocks, perforation was not considered a reality. For the impact with the non-rigid surface, the capacities of the cover blocks to resist fracture was determined in groups depending on depth, reinforcement, and span. The stiffness of the cover block also played a key role in the determination of the impact capacity.

For the impact with the soft ground (yielding), the analys is is different. The idea underlying the scenario with the soft ground is to determine the impact force by solving two simultaneous equations. These are equations of 
WHC-SD-WM-TI-775, Rev. 0

motion and soil reaction. The solutions of these simultaneous equations determine the depth of penetration of the falling equipment in ground and the impact force. This impact force was used to evaluate the integrity of the tank roof and the vault wall.

The results of the evaluations indicate that the perforation of the cover block from the falling equipment is not realistic. The energy as high as $29,000,000$ inch-pounds would be needed to perforate a 20 inch thick cover block if a 20,000 pound equipment is dropped from a height of 120 feet.

On the other hand, the results of the evaluations indicate that the cover blocks do not have adequate bending strength to resist impact. A failure of the cover block leading to an opening is most likely to occur due to the energy from the falling of a $20,0001 b$ equipment from any height. The results are tabulated in page 2 of this evaluations.

The impact with the soft ground was considered for three drop heights from 10 $\mathrm{ft}$ to $20 \mathrm{ft}$. The results show that the vault wall and roof for the DCRTs, catch tanks and the 200 series SSTs are adequate to withstand the impact. These results are tabulated along with the result of the perforation in page 1 of this evaluation. 
DESIGN ANALYSIS

Calc. No.

Revision 0

Page No. of $i$

Client WHC

Subject Evaluation for Impact Energy

WO/Job No.

F6NIAl

Subject Evaluation for Impact Energy
for DCRTs, Catch Tanks, and

Date

$5 / 7 / 96$ Checked $5-20$

By

200 Series SST

Location 200 Area Gen.

Revised

By RA. Islam

Scope

Evaluate the impact energy required to cause an opening in the cover block for DCRTs and Catch Tanks and roof of 200 Series SSTs. The evaluation will

specifically address the following:

a. Energy required to perforate the cover block.

b. Energy required to cause a bending failure in the cover block or in the roof when impact is associated with a non-yielding surface (cover block, concrete pit, riser etc.).

c. Energy required to cause a bending failure in the roof of 200 Series SST when impact is associated with a yielding surface (ground).

The perforation or the bending failure in the cover block or in the roof will lead to develop an opening in the containment for the tanks in DCRTs, Catch Stations, and 200 Series SST.

\section{Material Properties}

Concrete compressive strength, $f_{c}^{\prime}=3,000 \mathrm{psi}$;

Reinforcement, $f_{y}=60,000$ psi 
Calc No.

Revision 0

DESIGN ANALYSIS

Page No. $i \bar{i}$ of $i j$

Client WHC

Subject Evaluation for Impact Energy Date $5 / 7$

for DCRTs, Catch Tanks, and

200 Series SST

Location 200 Area Gen.
WO/Job No.

checked 5/20/96

F6N1A1

By

M.A. Is $1 \mathrm{am}$

R.A. Giller

Revised

By

\section{References}

1. Design of Structures for Missile Impact, BC-TOP-9-A, Revision 2, Bechte1 Power Corporation, November 1974.

2. ACI Building Code, ACI 318-89.

3. Design of Welded Structures, Chapter 2, 0.W. Blodgett, June 1966.

4. Supporting Document, WHC-SD-WM-SAR-067, Revision A.

5. Single-she11 Waste Tank Load Sensitivity Study, SD-RE-TI-012, March 1983.

6. Design of Machine Elements, Chapter 12, Second Edition; M.F. Spotts.

7. Structural Engineering Handbook, Chapters 5, Gaylord \& Gaylord 1968 Edition.

8. Introductory Soil Mechanics and Foundations, 3rd Edition, Sowers \& Sowers.

9. Hanford Plant Standards, GC-LOAD-01, (Formerly SDC-4.1, Rev 12).

10. Roark's Stress and Strain, 4th Edition

\section{Conclusion}

See pages 1 and 2 for the summary of the evaluations. 
HANFEÁO

WHC-SD-WM-TI-775, Rev. 0

DESIGN ANALYSIS

WO/Job No.

SUMMARY OF EVALUATIONS

A. Impact Energy Required to perforate Cover Block

\begin{tabular}{|c|c|c|c|c|c|}
\hline \multicolumn{2}{|c|}{ Tank Data } & \multicolumn{2}{|c|}{ Missile Data } & \multicolumn{2}{|c|}{$\begin{array}{l}\text { Energy Reqd. } \\
\text { for perferation }\end{array}$} \\
\hline Tank & $\begin{array}{c}\text { Cover Depth } \\
\text { (in) }\end{array}$ & $\begin{array}{c}\text { Weight } \\
\text { (ibs) }\end{array}$ & $\begin{array}{c}\text { Diameter } \\
\text { (in) }\end{array}$ & $\begin{array}{l}\text { Height of } \\
\text { Fall (h) } \\
\text { (in) }\end{array}$ & $\begin{array}{l}\text { Energy, } E \\
E=W(\text { W } \\
\text { (in-ibs) }\end{array}$ \\
\hline $\begin{array}{c}241-A-350 \\
(D C R T)\end{array}$ & 20 & 20,000 & 24 & $\begin{array}{l}1440 \\
(120 \mathrm{FT})\end{array}$ & $28,800,000$ \\
\hline
\end{tabular}

B. Impact with Yielding Surface (Ground)

\begin{tabular}{|c|c|c|c|c|c|c|c|c|}
\hline \multicolumn{2}{|c|}{ Tank Data } & \multicolumn{4}{|c|}{ Analysis Data (Assumed) } & \multicolumn{2}{|c|}{ Result } & \multirow{2}{*}{ Remarks } \\
\hline Tank & $\begin{array}{l}\text { Soill Gover } \\
\text { Depth } \\
\text { (in) }\end{array}$ & $\begin{array}{l}\text { Missile } \\
\text { Weight } \\
W(\text { ibs) } \\
\end{array}$ & $\mid \begin{array}{l}\text { Height } \\
\text { of tal } \\
h \text { (in) }\end{array}$ & $\begin{array}{l}\text { Soil Denst } \\
Y(\# / k F)\end{array}$ & $\begin{array}{l}\text { Soilfictic } \\
\text { Angle, } \\
\text { (Beg.) }\end{array}$ & $\begin{array}{l}\text { Force } \\
\text { e Impaci } \\
\text { fI Pllss }\end{array}$ & $\begin{array}{l}\text { Missile } \\
\text { Pentatic } \\
\text { in soil } \\
\text { (in) }\end{array}$ & \\
\hline $\begin{array}{c}200 \text { Series SST } \\
241-B, C, T, U\end{array}$ & $\begin{array}{c}144 \\
(12 F t)\end{array}$ & 20,000 & 120 & 125 & 30 & 55,897 & 74.5 & 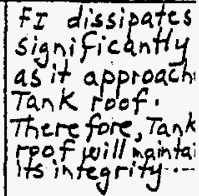 \\
\hline
\end{tabular}




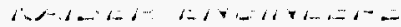

HARFERL

WHC-SD-WM-TI-775, Rev. 0 DESIGN ANALYSIS

Pace No. 2 of

WO/Job No.

Cient WHC

Date BY M.A. ISLAM

Subject Evaluation of Impact Erergy Date
Location 200 Area
Revised $5-20-$ By $R$ A Giller

SUMMARY OF EVALUATIONS CONTD.

C. Impact with non-yielding surface $2 . g$. coverblock, pit, riser ete

OCRTs

* using an equipment
weight, $w=20,000$ bs

\begin{tabular}{|c|c|c|c|c|c|}
\hline \multirow{2}{*}{ Group } & \multicolumn{4}{|c|}{ Tank Data } & \multirow{2}{*}{$\begin{array}{c}\text { * Energy Regd. to } \\
\text { Cause Bending Faitu } \\
\text { in Cover Block. } \\
(\text { in-1b) }\end{array}$} \\
\hline & Listed Tanks & $\begin{array}{l}\text { Cover } \\
\text { 3lock } \\
\text { Depih(in) }\end{array}$ & $\begin{array}{l}\text { Span } \\
\text { (in) }\end{array}$ & $\begin{array}{l}\text { Rebar } \\
\left.\text { Area } \text { int }^{2}\right)\end{array}$ & \\
\hline 1 & $241-A \cdot 350$ & 20 & 108 & $\begin{array}{l}55 ? 12 \\
A_{s}=31 / 9\end{array}$ & None \\
\hline 2 & $\begin{array}{r}244-T x, 244-u \\
-244=3 x\end{array}$ & 24 & 216 & $\begin{array}{l}48 @ 6 \\
A_{s}=1.58 / \mathrm{Ft}\end{array}$ & None \\
\hline 3 & $244-C R-\infty 3$ & 24 & 53 & $\begin{array}{l}16 @ 12 \\
A s=144 / F 4\end{array}$ & None \\
\hline 4 & $244-A, 244-5$ & 24 & 252 & $\begin{array}{l}15012 \\
A_{s}=144 / 4\end{array}$ & None \\
\hline \multicolumn{6}{|c|}{ CATCH TANKS } \\
\hline 1 & $\begin{array}{l}241-T X-302 C, 241-U X-302 A \\
241-A-302 A, 241-E R-311 \\
241-E W-151\end{array}$ & 20 & 72 & $\begin{array}{l}\pi 5 @ 12 \\
A s=31 / \mathrm{Ft}\end{array}$ & Noné \\
\hline 2 & $241=A x-152$ & 68 & 84 & $\# 6 @ 6, A_{5}=88$ & $\therefore$ None \\
\hline 3 & $241-5-304$ & 30 & 130 & $76012, A_{3}=16$ & None: \\
\hline 4 & $241-A=417$ & $2 @ 15=30$ & 96 & 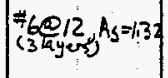 & $\therefore$ None \\
\hline & & & & $\vdots$ & \\
\hline $\begin{array}{l}\text { 200 Series } \\
\text { SST }\end{array}$ & $241-B, C, \pi, U$ & 12 & 240 & *t $6 @ 12$ & $\therefore$ None \\
\hline
\end{tabular}


KAISER ENGINEERS

HAIVFORO

$$
\text { WHC-SD-WM-TI-775, Rev. } 0
$$

DESIGN ANALYSIS
Calc. No.

Revision

Page No. 3 of

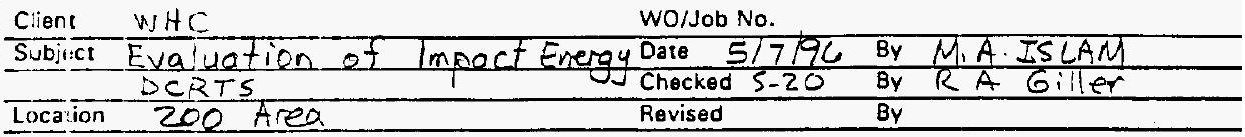

Double Contained Receiver Tanks (DARTs)

The following is a list of DCRTs:

$$
\begin{aligned}
& \left.\begin{array}{c}
* * * 244-5 \text { Lift station } \\
* * 244-7 x \text { Catch Station } \\
* * 244-U \text { it. }
\end{array}\right\} \quad 200 \text { w Area } \\
& \left.\begin{array}{cc}
* * 244-A & \text { Lift Station } \\
* * 244-3 x & \text { Catch Station } \\
* \text { * 244-CR-003 } & \text { Vault Tank } \\
* 241-A-350 & \text { Lift station }
\end{array}\right\} 200 \text { Area } \\
& \text { Ref. } \\
& \text { WHC-SD-WM-SAR- } \\
& \text { 067, } \operatorname{ReV} A
\end{aligned}
$$

* Group Designation: A

i- 8 thick Cover block
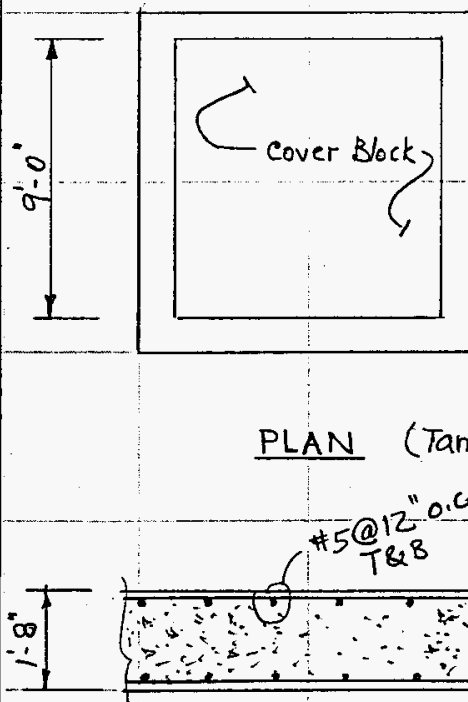

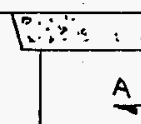

A
PLAN (TanK 241-A-350)

SEC: $A-A$

65

ELEVATION

54-4300-037 KEH.0037.00106/92 
KAISER ENGINEERS

WHC-SD-WM-TI-775, Rev. 0 DESIGN ANALYSIS
Ca'c. Vo.

Revision

Page No. 4 of

Client WHC WO/Job No

Subject Evaluation of Impact Energy Date $5 / 7996$ BY M, A-ISLAM Location 200 Area Checked $5-20$ By RA Gilled

Revised

By

Determine Energy Required to perforate Cover block

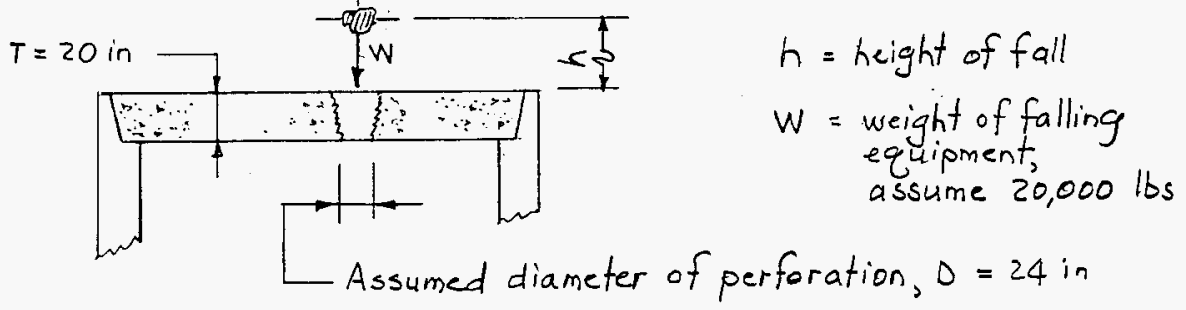

Refer to "Design of structures for Missile Impact, BC-TOP-9.A, Rev ? "by Bechtel Power Corp. Nov, 1974

The thickness of a concrete element that will be perforated by a missile (falling object)

$$
\begin{aligned}
& T=\frac{427}{\sqrt{f_{c}^{\prime}}} \cdot \frac{W}{D^{1.8}} \cdot\left(\frac{V_{s}}{1000}\right)^{1.33} \text { where } f_{c}^{\prime}=3000 P_{s i} \\
& \begin{aligned}
V_{s}= & \text { striking Velocity } \\
\mathrm{ft} / \mathrm{sec} &
\end{aligned} \\
& \text { Velocity, } V_{s}=\sqrt{2 g h}=\sqrt{2 \times 32.2 h}=8.025 h^{1 / 2} \\
& V_{s}^{4 / 3}=(8.025)^{4 / 3} \cdot h^{\frac{1}{2}} \cdot 4 / 3=16.07(h)^{2 / 3} \\
& \therefore T=\frac{427}{\sqrt{3000}} \cdot \frac{W}{(24)^{1.8}} \cdot \frac{16.07(h)^{2 / 3}}{(1000)^{1.33}}=.000041067 \mathrm{~W}(h)^{2 / 3} \\
& w h^{2 / 3}=\frac{20}{.000041067}=486,998 \\
& \text { if } w=20,000 \text { lbs, } h=120 \mathrm{Ft}
\end{aligned}
$$

Therefore, Energy read, $E=w h=20000 \times 120 \times 12=28,800,000$ to cause perforation of the cover $\$ 100 \mathrm{~K}_{54.430 .037}$ 66 


KAISER ENGINEERS WHC-SD-WM-TI-775, Rev. 0
HANFORD

The results of the evaluation for the perforation of the cover block indicate that a $20,000 \mathrm{~b}$ equipment, if dropped from a height of 120 Feet the cover block will be perforated with a hole diameter of 2 Feet.

20,000 ib equipment $2 \mathrm{FH}$. dian perforation are realistic, however height of $120 \mathrm{Ft}$, is unrealistic. Therefore, the results conclude that the cover block, under normal impact scenario, will not be perforated.

Determine Energy Reg, to cause a crack (opening) in cover blow

Moment Capacity of the cover block:

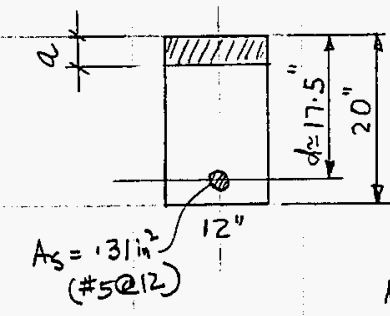
Locate Concrete compression block,

$$
a=\frac{A_{s} f_{y}}{.85 \times b \times f_{c}^{\prime}}=\frac{131 \times 60000}{.85 \times 12 \times 3000}={ }^{\prime} 6078^{\prime \prime}
$$

Ultimate Moment Capacity, $M_{4}$

$$
\begin{aligned}
M_{4} & =\phi A_{s} f_{y}(d-a / 2)=1 \times 31 \times 60000(17,5-6078 / 2) \\
& =319,848 \mathrm{in}-1 b / F t
\end{aligned}
$$

Find Bending moment to be developed by the fall of $W$,

$$
\omega_{D L}=\frac{20}{12} \times 150 \times 1:=250 \# /, ; M_{D L}=\frac{w L^{2}}{8}=\frac{150 \times 9^{2}}{8} \times 12=30,375^{15}
$$

Max bending Moment. Me due to $P \& D L$

$$
\begin{aligned}
& M_{u}=\frac{P L}{4}+M_{L L} \text { or } P=\frac{4\left(M_{4}-M_{D L}\right)}{L} \\
& P=\frac{4(319848-30375)}{9 \times 12}=10,72 l^{\# / F+o f \text { width }}
\end{aligned}
$$

where $P$ is the impact load caused by the fall of $W$ from a height of $h$

54.4300-037 KEH-0037.00 106/92 67 


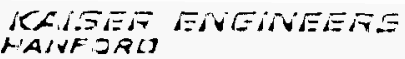

WHC-SD-WM-TI-775, Rev. 0 DESIGN ANALYSIS vac. Vo.

Revision

Page No. 6 of

Client Nite WO/Job No.

Subject Evalua Ion of impact Energy Date $5 / 8 / 96$ By M. A. ISLAM Location $2 \theta O$ Area DCRTS Catch Tanks Revised By

$$
\therefore \quad P=10,7.21 \#(\text { Impact load })
$$

Refer to Blodgett's "Design of Welded Structures", Chapter 2

Impact Load, $P=W+\sqrt{W^{2}+2 K W(h)}$ where $K$ is bending
stiffness of the cover block

Because cover block is simply. supported and loaded by $P$,

$$
\begin{aligned}
K=\frac{48 E I}{L 3} \text { where } E & =3 \times 10^{6} \text { Psi for concrete } \\
=\frac{48 \times 3 \times 10^{6} \times 8,000}{108^{3}} & =\frac{b d^{3}}{12}=\frac{12 \times 20^{3}}{12} \\
& =8,000 \mathrm{in}^{4}
\end{aligned}
$$

$$
\begin{aligned}
\therefore \quad P= & 10,721=w+\sqrt{w^{2}+2 k w h}, \quad u \operatorname{sing} w=20,000^{\#} \\
& 20000+\sqrt{20000^{2}+2 \times 914495 \times 20000(h)}=70,721 \\
& \sqrt{20000^{2}+2 \times 914495 \times 20000(h)}=-9279
\end{aligned}
$$$$
h=-0009 \text { in }
$$

$\therefore$ Energy, E needed for failure is insignificant conclusion: Because bending strength $\left(M_{4} @ A_{s}=31 / \mathrm{m}^{2}\right)$ is small stiffness of cover block ( $K$ ) is high, very small energy is enough to cause a crack in the cover block. This crack will eventually develop an opening in cover block.

54-4300-057 KEH-0537.00766/92

68

$\mathrm{l} \mathrm{Il}^{\mathrm{r}}$

1 


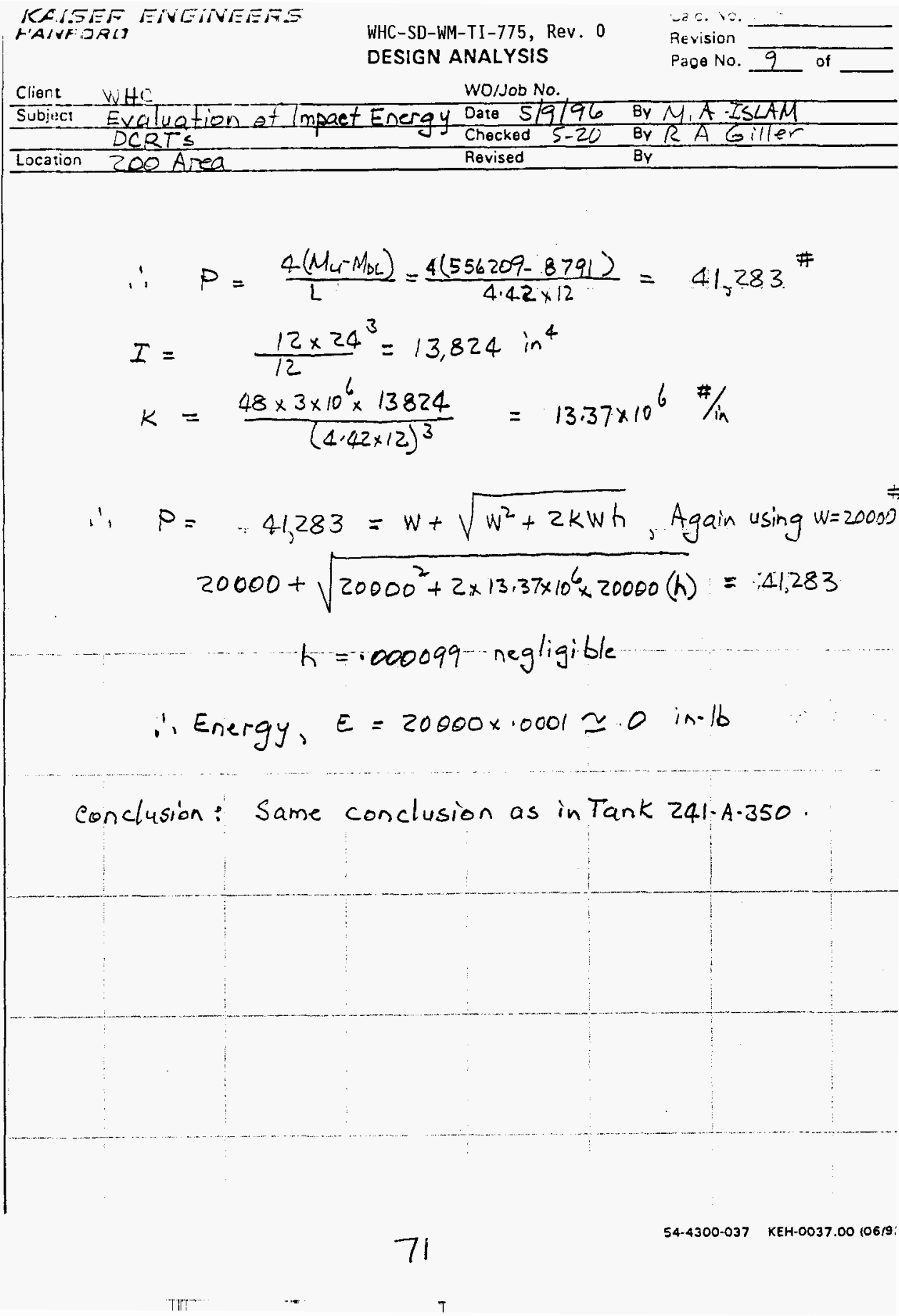




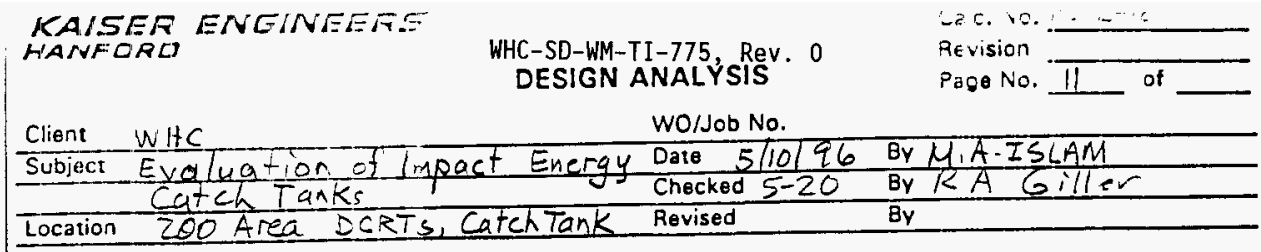

Catch Tanks

The following is a list of Catch Tanks:

$$
\begin{aligned}
& \left.\begin{array}{c}
* * * 241-5-304 \\
* 241-T x 302 c \\
* 241-V x-3010
\end{array}\right\} \text { 200W Area } \\
& \begin{array}{c}
241-U-301 B \\
* 241-U x-302-A
\end{array}
\end{aligned}
$$

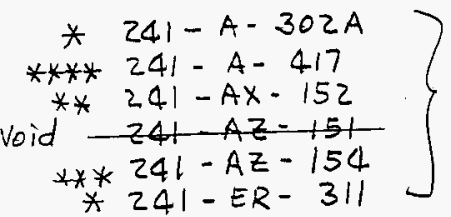

$$
\begin{aligned}
& \text { * 241- EW- } 151 \quad 600 \text { Area }
\end{aligned}
$$

Ref.

$$
\begin{aligned}
& \text { WHC-SD-WM-SAR- } \\
& 067 \text {, ReVA }
\end{aligned}
$$

Catch Tanks 241-TX-302C

$$
\begin{aligned}
& 241-U X-302 A \\
& 241-A-302 A \\
& 241-E R-311 \\
& 241-E W-151
\end{aligned}
$$
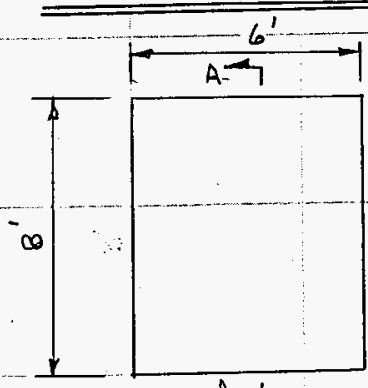

A

PLAN (241-EW-15U)

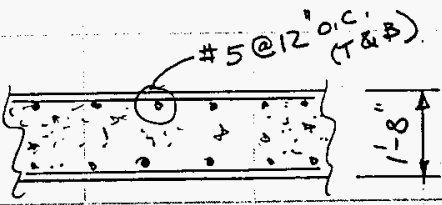

SEC AAA

(Section corresponds to 241-A.302
Similarly,

$$
\begin{gathered}
d=20-2.5=17.5^{\prime \prime} \\
w_{\Delta L}=1.4 \times \frac{20}{12} \times 150=350 \% / F \\
M_{U}=1 . \times 31 \times 60000\left(17.5-\frac{.6078}{2}\right)^{2} \\
=319,847 \mathrm{in}-1 \mathrm{~b} / \mathrm{Ft} \\
M_{O L}=\frac{250 \times 6^{2}}{8} \times 12=13,500 \mathrm{in} \cdot 16 \\
54-4300.037 \mathrm{KEH}-0037.00106 / \mathrm{s}
\end{gathered}
$$

73 


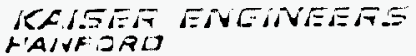

$$
\begin{aligned}
& \text { WHC-SD-WM-TI-775, Rev. } 0 \\
& \text { - } \\
& \text { DESIGN ANALYSIS } \\
& \text { Page No. } 12 \text { of } \\
& \text { Client N } \mathrm{HC} \\
& \text { WO/Job No. } \\
& \text { Subjicr Evaluation of mpoct Energy Date } 5 / 10196 \text { By M.A. ISLTM } \\
& \text { Location } 200 \text { A PeC } \\
& \text { Revised } \\
& \text { Impact force, } P=\frac{4\left(M_{4}-M_{0 x}\right)}{L}=\frac{4(319847-13,500)}{6 \times 12}=1.7,019^{\#} \\
& I=\frac{12 \times 20^{3}}{12}=8000 \mathrm{in}^{4} \text {; } \\
& K=\frac{48 \times 3 \times 10^{6} \times 8000}{(6 \times 12)^{3}}=3.086 \times 10^{6} \mathrm{\#} / \mathrm{in} \\
& \therefore \quad P=17,019=w+\sqrt{w^{2}+2 k w(h)}, \quad \text { using } w=20000 \\
& 20000+\sqrt{20000^{2}+2 \times 3.086 \times 10^{6} \times 20000(h)}=17,019 \\
& h=\text { negative }
\end{aligned}
$$

Insignificant energy needed to cause a failure.

Conclusion: The result is identical to DenT $241-A-350$

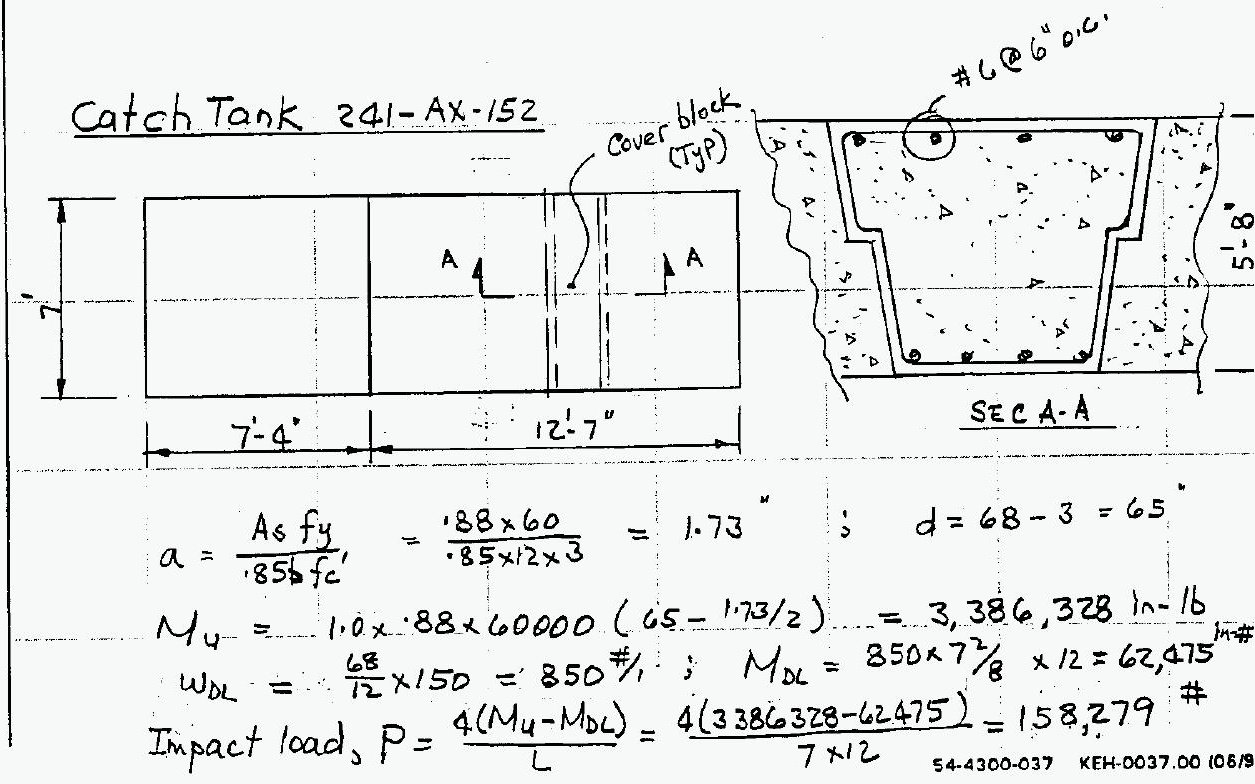

74 


$$
\begin{aligned}
& \begin{array}{c}
\text { KAISEr, ENGINEEITE } \\
\text { HANFORd }
\end{array} \\
& \text { WHC-SD-WM-TI-775, Rev. } 0 \\
& \text { DESIGN ANALYSIS } \\
& \text { Revision } \\
& \text { Page No. } 13 \text { of } \\
& \text { WO/Job No. } \\
& \text { Client WHC } \\
& \begin{array}{c}
\frac{c o c h \text { Tank }}{200 \text { Area }} \\
I=\frac{12 \times 65^{3}}{12}=274625 \mathrm{in}^{4}
\end{array} \\
& K=\frac{48 \times 3 \times 10^{6} \times 274625}{(7 \times 12)^{3}}=66.7 \times 10^{6} \mathrm{~m} / \mathrm{in} \\
& P=158,279=w+\sqrt{w^{2}+2 k w(h)} \text { using } w=20000^{\#} \\
& 20000+\sqrt{20000^{2}+2 \times 66.7 \times 10^{6} \times 20000(h)}=158,279 \\
& h=007 \text { negligible }
\end{aligned}
$$
Insignificant energy is enough to fail the cover block
and develop an opening

Catch Tank 241-5-304 \& 241-AZ-154

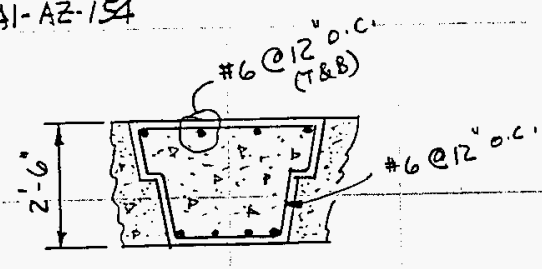

SEC. AAA

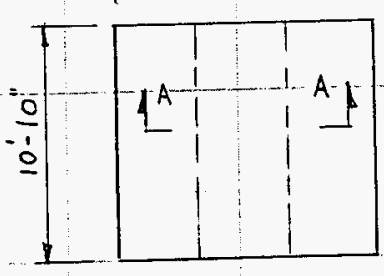




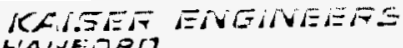

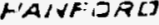

WHC-SD-WM-TI-775, Rev. 0

DESIGN ANALYSIS
Revision

Page No. 14 of

Subject Eve luetic of impact Energy Date $5 / 13 / 96$ By MIA.TSLAM

WO/Job No.

Location EQ Area

Revised

$$
\begin{gathered}
I=\frac{12 \times 27.5^{3}}{12}=20.797 \mathrm{in}^{4} \\
K=\frac{\frac{48 \times 3 \times 10^{\circ} \times 20797}{(10.83 \times 12)^{3}}=1.36 \times 10^{6} \mathrm{~F} / \mathrm{k}}{P=} \\
P=w+\sqrt{w^{2}+2 \mathrm{kw}(h)} \quad \text { using } w=20000^{\#} \\
20000+\sqrt{20000^{2}+2 \times 1.36 \times 10^{6} \times 20000(h)}=19.964 \\
h=\text { Negative }
\end{gathered}
$$

Insignificant energy is enough to fail the cover block and develop an opening in the cover block.

Catch Tank 241-A-417

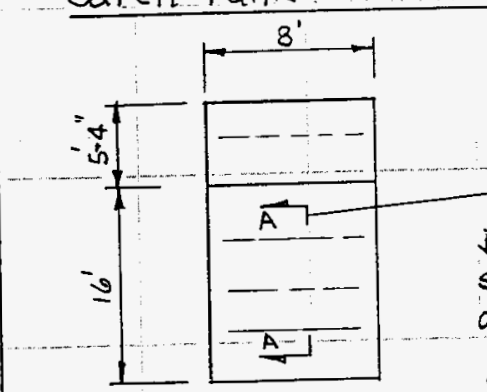

Because compression block (a) is usually small consider 3 layers of re-bar will be available in tension.

Determine ' $d$ '

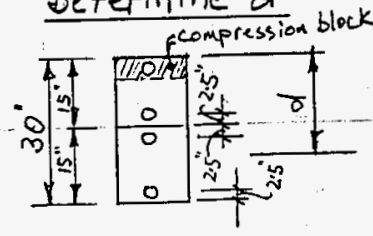

$$
\begin{aligned}
& .44 \times 2.5=1.1 \\
& .44 \times 2 \times 15=\frac{13.2}{14.3} \\
& \frac{1.32}{y}=\frac{14.3}{1.32}=10.83^{11} \\
& d=30-10.83=19.17^{\prime \prime} \\
& 54.4300 .037 \text { KEH.0037.00 10619 }
\end{aligned}
$$

76

[II

T 
KAISER ENEWVEOUES
HAVFERU

WHC-SD-WM-TI-775, Rev. 0

Revision

DESIGN ANALYSIS

Pagan No. 15 of

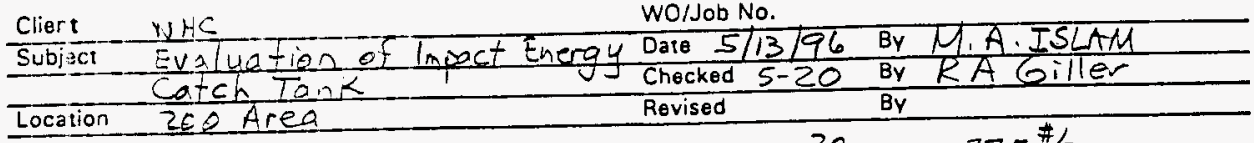

$$
\begin{aligned}
& \begin{array}{ll} 
& \omega_{\Delta L}=\frac{30}{12} \times 150=375 \% / \mathrm{F} \\
a=\frac{(3 \times .44) \times 60}{185 \times 12 \times 3}=2.59^{\prime \prime} ; & M_{D L}=375 \times \frac{8^{2}}{8} \times 12=36,000 \mathrm{in}-16 \\
M_{u}=1.0 \times 3 \times 16 \times 60000(19.17-2.59 / 2)=1,415,700 \mathrm{in}-\mathrm{bb} / \mathrm{ft}
\end{array} \\
& I=\frac{12 \times 30^{3}}{12}=27,000 \mathrm{in}^{4} \\
& K=\frac{48 \times 3 \times 10^{6} \times 27000}{(8 \times 12)^{3}}=4.39 \times 10^{6} \mathrm{~m} / \mathrm{in} \\
& P=\frac{4\left(M_{4}-M_{D L}\right)}{L}=\frac{4(1,4,15,700-36,000)}{8 \times 12}=57,488^{\#} \\
& \therefore P=57,488=w+\sqrt{w^{2}+2 k W(h)}, \quad \text { using } w=20000^{\frac{*}{7}} \\
& 20000+\sqrt{20000^{2}+2 \times 4139 \times 10^{6} \times 20000(h)}=57488 \\
& \therefore h=.006 \text { in Negligible }
\end{aligned}
$$

$\therefore$ Insignificant energy is enough to cause failure in cover block and develop an opening eventually

77

54-4300.037 KEH.0037.00 $106 / 9$ 


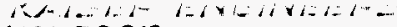

HARVE $=R L$
WHC-SD-WM-TI-775, Rev. 0 DESIGN ANALYSIS
Revision

Pape No. 16 of

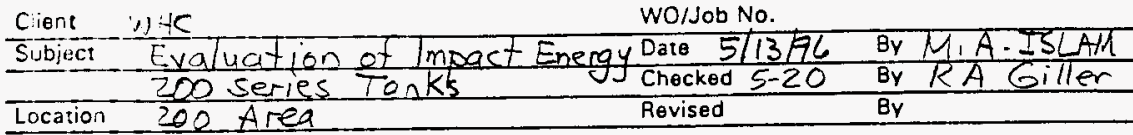

200 Series Tanks $(241-B, C, T, U)$

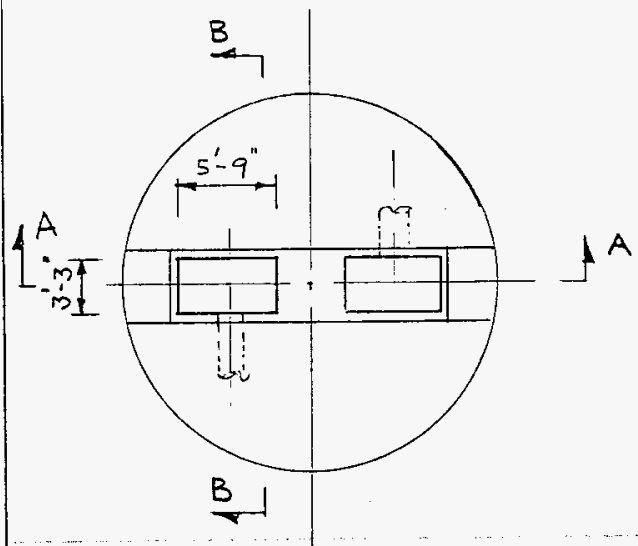

* From Ramble Report,

(SD-RE-TI-OIZ)
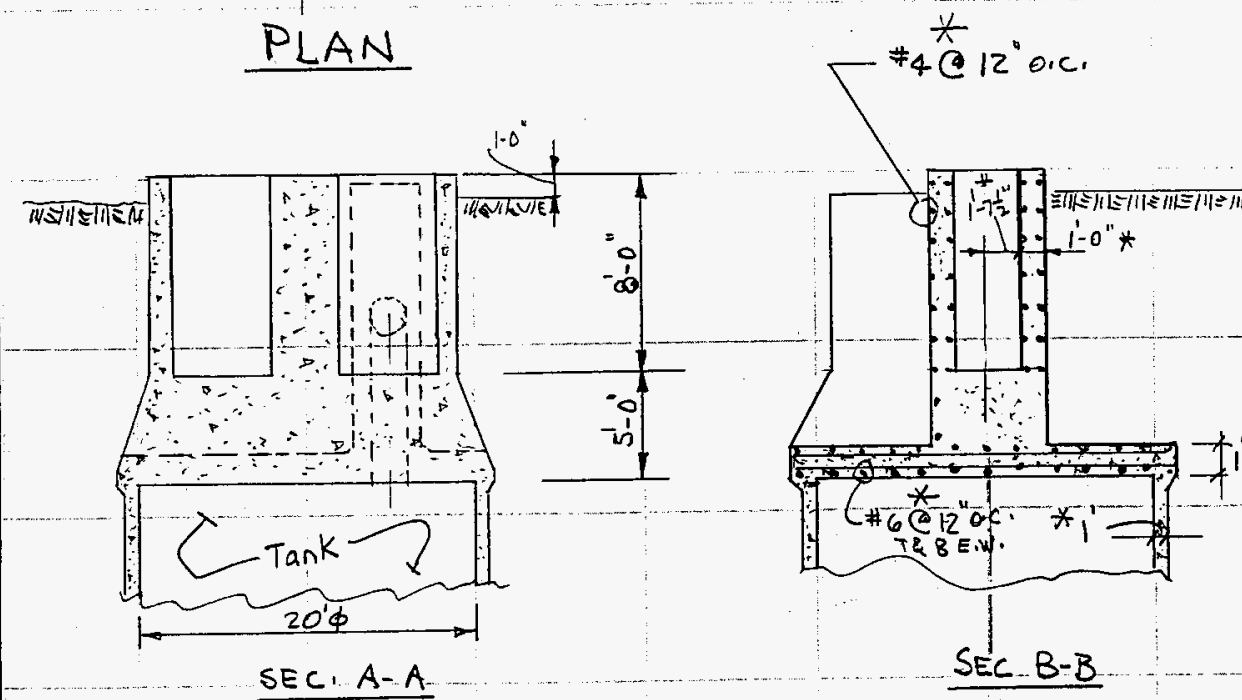


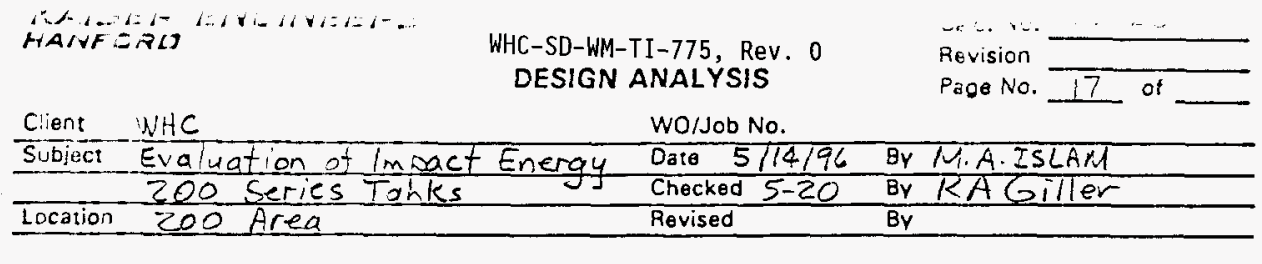

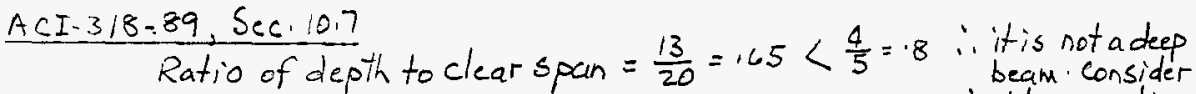
' $T$ ' bears action

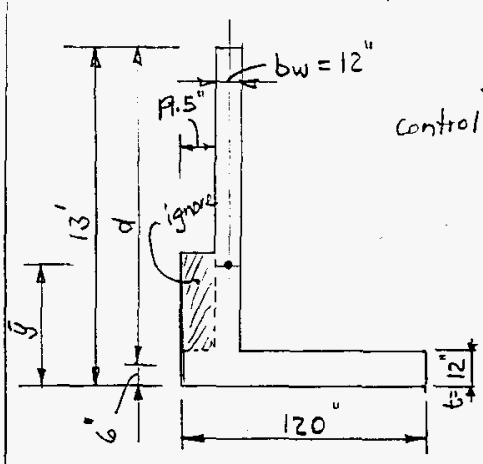

Eff. width of ' $T$ 'beam (sec.8.10,3)

$\Rightarrow$ i) $b_{w}+\frac{1}{12} \operatorname{span}+19.5=12+\frac{1}{12} \times 20 \times 12+19.5=51.5^{\prime \prime}$ ii) $6 t=6 \times 12=72^{\prime \prime}$

iii) space of beam, (use halfspan) $=120^{\prime \prime}$

Total re-bar in width (\#6e12")

$A_{s}=\frac{5 \times .44 \times \sum_{\text {LES. }}}{l_{T B}}=4.4 \mathrm{in}^{2}$

$d=13 \times 13-6=150^{\prime \prime} ;$ Span, $L=20^{\prime}$

$a=\frac{\text { As } f_{y}}{.85 b f_{c}}=\frac{4.4 \times 60}{.85 \times 12 \times 2.5}=10.35^{\circ}$

$f_{C}^{\prime}=2500$ Psi per Dug. HW-72417. $w_{D L}=\frac{12 \times 120+12 \times 13 \times 12}{144} \times 150=3450^{\prime \prime}$

$$
\begin{aligned}
\therefore M_{u} & =\phi A_{s} f_{y}(d-a / 2)=1.0 \times 4.4 \times 60000\left(150-\frac{10.35}{2}\right) \\
& =38,233,800 \mathrm{in}-16 \Rightarrow M_{O L}=3450 \times \frac{20^{2}}{8} \times 12=2,070,000
\end{aligned}
$$

Max. Impact load, $P=\frac{4\left(M_{4}-M_{D L}\right)}{L}=\frac{4(38233,800-2,07000)}{20 \times 12}$

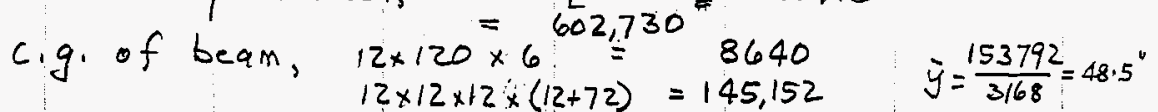

$\frac{12 \times 12 \times 12 \times(12+72)}{3168}=\frac{145,152}{153,792}$

$I=\frac{12 \times 144^{3}}{12}+12 \times 144(12+72-48.5)^{2}+12 \times 120(48.5-6)^{2}=7.76 \times 10^{6} \mathrm{in}^{4}$

$K=\frac{48 \times 3 \times 10^{6} \times 776 \times 10^{6}}{(20 \times 12)^{3}}=80.9 \times 10^{6} \mathrm{~F} / \mathrm{in}$

$P=602,730=w+\sqrt{w^{2}+2 k w(h)} \quad u \operatorname{sing} w=20000^{\#}$

$h=105$ in

$\therefore$ Energy $E=20000 \times 105=2096 \mathrm{in}-1 \mathrm{~b} \Rightarrow$ Negligible

insignificant energy is enough to cause failure in roof covering tank

79

$T$ 


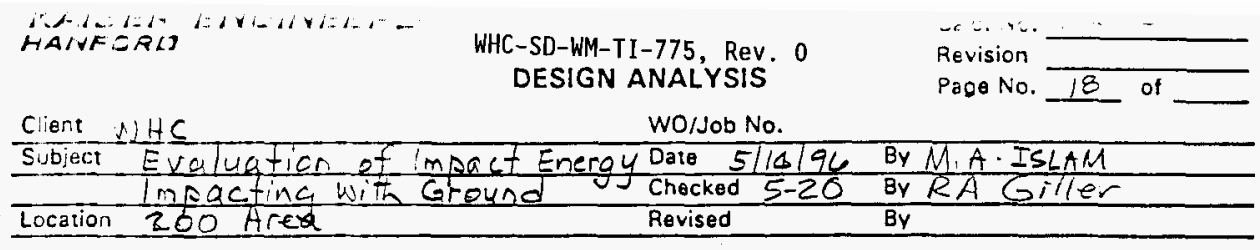

Equipment to drop onto soft Ground (Yielding Surface)

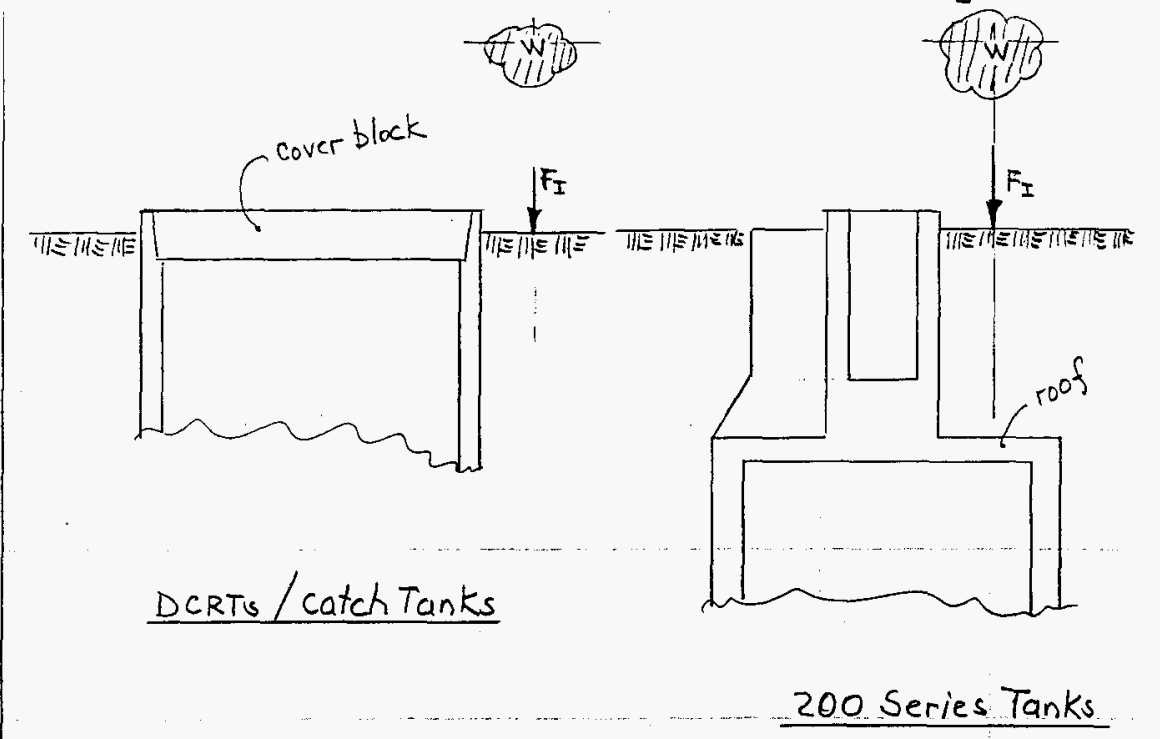

Equipment weight, $w_{1}$ dropping onto the soft ground produces impact load $F_{I}$ which will act as surcharge load for the - DARTs and ca'tch-tanks. However, $f_{1}$ in the case- of 200 SeriesTanks will ea use bending in roof of tank.

First the impact load $F_{I}$, will be determined and then it will be reviewed if it may cause failure in the wall or roof.

Assumptions:

1. Unit wt. of soil, $Y=125^{*} / C F$

2. Angle of internal fiction, $\phi=30^{\circ}$

3. -Foot print of impact, 2-Ft. ia.

4. Equipment weight, $W=20000^{\text {\# }}$ and height of fall, $h=120^{\circ}$

80

54-4300-037 KEH-0037.00 106/92

\|\|

† 
KAISER RIVGWVEEAS

WHC-SD-WM-TI-775, Rev. 0

-2 C. $\triangle$

DESIGN ANALYSIS

Revision

Papen No. 20 of

Client NHC

Wo/Job No.

Subject Evaluation of Impact Energy

Date $5 / 14 / 96$ By M.A. ISLAM

Location 200 Area

Revised

In order to maintain equilibrium, $F_{I}$ must equal is

$$
\begin{aligned}
& \therefore 20000\left[1+\sqrt{1+\frac{240}{\Delta}}\right]=6274+735.4(\Delta) \\
& 1+\sqrt{1+\frac{240}{\Delta}}=.3137+.03677(\Delta) \\
& .03677(\Delta)-\sqrt{1+\frac{200}{\Delta}}=.6863 \\
& \text { Try } \Delta=70^{\circ}, \quad \text { L.H.S. }=1469 \\
& 75^{\prime \prime}, \quad 11=108 \\
& \begin{aligned}
74.5^{\prime \prime}, "=.685 \Rightarrow \therefore \Delta=74.5^{\prime \prime} & =6.208^{\circ}
\end{aligned}
\end{aligned}
$$

$$
\text { Impact Load, } \begin{aligned}
F_{I} & =20000\left[1+\sqrt{1+\frac{2 \times 120}{\Delta}}\right]=20000\left[1+\sqrt{\frac{200}{74.5}+1}\right. \\
& =61,092
\end{aligned}
$$

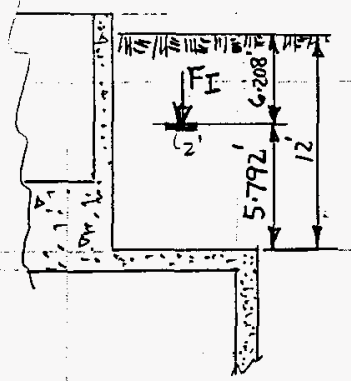

Determine. Impact load@ roof top, FI (R) Refer Fig. 9.12, introductory Soil Mechanics and Foundations, ard Ed.

- Sowers \& Sowers

Load coefficient e 5.792 $=.175$

$$
\therefore \text { Net } F_{5}=175 \times 61,092=10,691
$$

3 y comparison to previous analysis we can con dude that $10.691^{*}$ load will not cause failure in the integrity of the roof.

Similarly, for DARTs and Catch Tanks, Fill develop a surcharge load (radial to tank vault wall), $P$

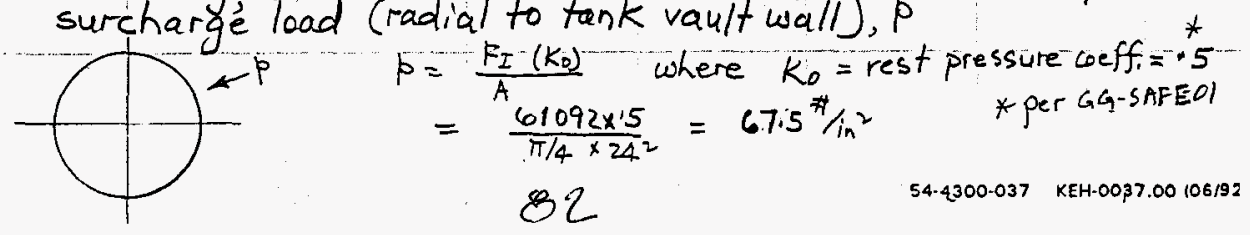


KAISER ENGINEERS

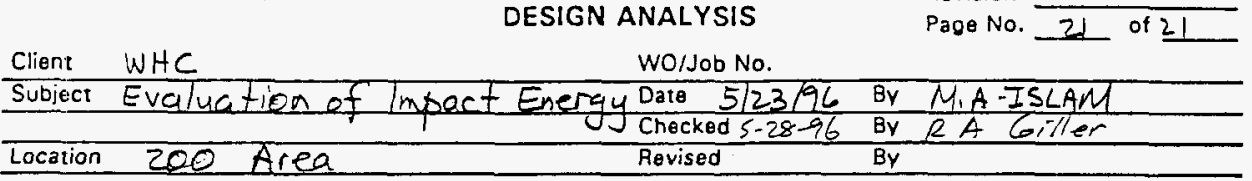

From Roark's (th Ed.), Table XIII, case 12

$$
\begin{aligned}
& \text { Max } M \text { (due to } p)=\frac{p}{2 \lambda^{2}} e^{-b \lambda} \sin b \lambda \quad \begin{array}{c}
\text { use Vault } R=54 " \\
\text { " } t=18 "
\end{array} \\
& \lambda=\left[\frac{3\left(1-\nu^{2}\right)}{R^{2} t^{2}}\right]^{1 / 4}=\left[\frac{3\left(1-15^{2}\right)}{54^{2} \times 18^{2}}\right]^{\frac{1}{4}}=.042 \\
& \therefore M=\frac{67.5}{2 \times .042^{2}} \times e^{-12 \times .042} \times \sin (12 \times 042)=101.7 \stackrel{\#-i n}{\Rightarrow} \text { Small }
\end{aligned}
$$

Vault walls are ok.

Consider other drop heights.

Try $h=15^{\prime}$, from page 20, $103677(\Delta)-\sqrt{1+\frac{2 h}{\Delta}}=.6863$

$$
\begin{aligned}
& \therefore .03677(\Delta)-\sqrt{1+\frac{360}{\Delta}}=.6863 \\
& h=120 " \\
& \Delta=81.8^{\prime \prime} \Rightarrow F_{I}=20000\left[1+\sqrt{1+\frac{2 \times 180}{81.8}}=66,480^{\#}\right. \\
& \text { Try } \left.h=20^{\prime} \text {, similarly, .03677( }{ }^{\prime}\right)-\sqrt{1+\frac{2 \times 240}{\Delta}}=16863 \\
& \Delta=87.8^{\prime \prime} \Rightarrow P_{I}=70,860^{\#}
\end{aligned}
$$

Change in impact load for increased drop heights will not cause failure either to vault wall or roof.

83

$54.4300 .037 \quad \mathrm{KEH}-0037.00106 / 921$ 
WHC-SD-WM-TI-775, Rev. 0

\section{Appendix 3}

Internal Transient Pressure Caused by Hydrogen Deflagration 


\section{Appendix 3}

\section{Internal Transient Pressure Caused by Hydrogen Deflagration.}

The following catch tanks, Double-Contained Receiver Tanks (DCRT), and 200-Series Single Shell Tanks (SST) were evaluated for a peak pressure of 120 psig for a Hydrogen deflagration inside the primary waste tank. For catch tanks and DCRT's having a primary steel tank within a reinforced concrete vault, the peak pressure was applied inside the primary steel tank. The peak pressure was assumed to be applied instantaneous. A static pressure evaluation was performed using a dynamic load factor of two in order to account for the instantaneous application of pressure.

\begin{tabular}{ll} 
Catch Tanks (CT) & Double-Contained Receiver Tanks (DCRT) \\
\hline $241-A-302-A$ & $244-A$ Lift Station \\
$241-A-417$ & $241-A-350$ Lift Station \\
$241-A X-152$ & $244-B X$ Catch Station \\
$241-A Z-151$ & $244-C R-003$ Vault Tank \\
$241-A Z-154$ & $244-S$ Lift Station \\
$241-E R-311$ & $244-T X$ Catch Station \\
$241-E W-151$ & $244-U$ Catch Station \\
$241-S-304$ & \\
$241-T X-302-C$ & 200-Series Single-Shell Tanks (SST) \\
$241-U-301-B$ & $241-B$ - 200-Series SST \\
$241-U X-302-A$ & $241-C$ 200-Series SST \\
& $241-T 200-$ Series SST \\
& $241-U 200-$ Series SST
\end{tabular}

The subject catch tanks, DCRT's, and 200-Series SST's were evaluated for loss of confinement for the waste. Loss of confinement occurs when an unobstructed opening or path is created between the waste and atmosphere. Therefore, the structural failures that were evaluated in this assessment were those that would cause the rupture of the steel tank structure and subsequent failure of the reinforced concrete vault. The concrete vaults of the DCRT's were evaluated in Appendix 5 for a gasoline fire and the resulting pressure of $140 \mathrm{psi}$ and were concluded to fail and result in an unobstructed opening to the atmosphere. As such, the concrete vaults of catch tanks, DCRT's, and 200-Series SST's not having primary steel tanks are concluded to fail if exposed to a hydrogen deflagration pressure of $120 \mathrm{psi}$. The catch tanks and DCRT's having a primary steel tank within a reinforced concrete vault whose primary steel tank fails due to the 120 psig internal pressure are assumed to have loss of confinement and unobstructed opening or path between the waste and atmosphere due to subsequent failure of the concrete vault structure surrounding the tanks. The catch tanks that are buried directly in the soil will not have unobstructed openings between

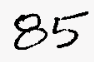


WHC-SD-WM-TI-775, Rev. 0

the waste and atmosphere even if the tank were to rupture.

Following as a table summarizing the evaluation of the steel tanks for 120 psig internal pressure. 
Table 3.1 Internal Transient Pressure Summary

\begin{tabular}{|c|c|c|c|c|c|c|}
\hline & VESSEL MATERIAL & $\begin{array}{l}\text { VESSEL } \\
\text { DIA }\end{array}$ & $\begin{array}{l}\text { WALL } \\
\text { THICKNESS }\end{array}$ & $\begin{array}{l}\text { WALL STRESS } \\
\text { (1) }\end{array}$ & $\begin{array}{l}\text { YIELD } \\
\text { STRESS }\end{array}$ & STATUS \\
\hline \multicolumn{7}{|l|}{ Catch Tanks } \\
\hline $241-\mathrm{A}-302-\mathrm{A}$ & $\begin{array}{l}\text { carbon steel } \\
\text { direct buried }\end{array}$ & $9 \cdot-0 "$ & $9 / 16^{\prime \prime}$ & $23,040 \mathrm{psi}$ & $30,000 \mathrm{psi}$ & oK \\
\hline $241-A-417$ & \multicolumn{3}{|c|}{ lined concrete vault, no vessel } & & & Vault Fails \\
\hline $241-\mathrm{AX}-152$ & \multicolumn{3}{|c|}{ lined concrete vault, no vessel } & & & Vault Fails \\
\hline $241-\mathrm{AZ}-151$ & \multicolumn{3}{|c|}{ lined concrete vault, no vessel. } & & & Vault Fails \\
\hline $241-\mathrm{AZ}-154$ & \multicolumn{3}{|c|}{ lined concrete vault, no vessel } & & & Vault Fails \\
\hline $241-E R-311$ & $\begin{array}{l}\text { carbon steel } \\
\text { direct buried }\end{array}$ & $9 \cdot-0 "$ & $9 / 16^{\prime \prime}$ & 23,040 psi & $30,000 \mathrm{psi}$ & oK \\
\hline $241-\mathrm{EW}-151$ & stainless steel & $4^{\prime}-5^{\prime \prime}$ & $3 / 8 "$ & $17,280 \mathrm{psi}$ & 25,000 psi & OK \\
\hline $241-5-304$ & carbon steel & $9^{\prime}-0^{\prime \prime}$ & $5 / 8 "$ & $20,736 \mathrm{psi}$ & 30,000 psi & $\mathrm{OK}$ \\
\hline $241-T X-302 C$ & $\begin{array}{l}\text { carbon steel } \\
\text { direct buried }\end{array}$ & $9^{\prime}-0 "$ & $1 / 2 "$ & 25,920 psi & $30,000 \mathrm{psi}$ & oK \\
\hline $241-\mathrm{U}-301 \mathrm{~B}$ & \multicolumn{3}{|c|}{ precast concrete vault, no vessel } & & & Vault Fails \\
\hline $241-U X-302 A$ & $\begin{array}{l}\text { carbon steel } \\
\text { direct buried }\end{array}$ & $9-0^{\prime \prime}$ & $1 / 2^{\prime \prime}$ & $25,920 \mathrm{psi}$ & $30,000 \mathrm{psi}$ & OK \\
\hline \multicolumn{7}{|c|}{ Double-Contained Receiver Tanks } \\
\hline $244-\mathrm{A}$ & & & & not evaluated & & $\begin{array}{l}\text { Vault Fails } \\
\text { See Appendix } \\
5\end{array}$ \\
\hline $241-\mathrm{A}-350$ & stainless steel & $4^{\prime}-5^{\prime \prime}$ & $3 / 8^{\prime \prime}$ & 17,280 psi & $25,000 \mathrm{psi}$ & $\mathrm{OK}$ \\
\hline
\end{tabular}




\begin{tabular}{|c|c|c|c|c|c|c|}
\hline $244-B X / T X / U$ & carbon steel & $12^{\prime}-0^{\prime \prime}$ & $1 / 4^{\prime \prime}$ & $69,120 \mathrm{psi}$ & $30,000 \mathrm{psi}$ & $\begin{array}{l}\text { Tank } \\
\text { Ruptures } \\
\text { Vault Fails } \\
\text { See Appendix } \\
5\end{array}$ \\
\hline $244-C R-003$ & stainless steel & & $3 / 8 "$ & not evaluated & & $\begin{array}{l}\text { Vault Fails } \\
\text { See Appendix } \\
5\end{array}$ \\
\hline $244-5$ & carbon steel & $15^{\prime}-0^{\prime \prime}$ & $1 / 4 "$ & $86,000 \mathrm{psi}$ & $30,000 \mathrm{psi}$ & $\begin{array}{l}\text { Tank } \\
\text { Ruptures } \\
\text { Vault Fails } \\
\text { See Appendix } \\
5\end{array}$ \\
\hline \multicolumn{7}{|c|}{200 -Series single shell Tanks } \\
\hline $241-\mathrm{B} / \mathrm{C} / \mathrm{T} / \mathrm{U}$ & \multicolumn{3}{|c|}{ lined concrete vault, no vessel } & & & Vault Fails \\
\hline
\end{tabular}




$$
\text { P. 4-1 }
$$

WHC-SD-WM-TI-775, Rev. 0

Appendix 4

Seismic Event 


\section{Appendix 4}

\section{Seismic Event}

The task is to determine the maximum free field ZPA that would not result in a loss of confinement for each of the catch tanks, DCRTs and the 200-series tanks. These are buried structures. Simple methods based on code practice are coupled with engineering judgement to make the required determinations. Considerable uncertainty and most likely conservatism are expected with the soil effects. Further refinement requires soil-structure interaction analysis with finite element methods.

In general, code capacities are conservative when compared with expected loads in seismic events, especially with ductile structures. Given a design basis earthquake, DOE practice typically reduces the seismic demand before comparison with code capacity. Determining the ZPA herein that would not result in a loss of confinement is guided by DOE Standard 1020-94. Consider PC 3 structures. Appendix $C$ of 1020, Section C.2.1, has a Scaled Design/Evaluation Bas is Earthquake SDBE defined by

$$
\text { SDBE }=1.5 \times S F \times D B E
$$

where

$$
\begin{aligned}
S F & =\text { scale factor, }=1 \text { for } P C 3 \\
D B E & =\text { design basis earthquake, } g .
\end{aligned}
$$

The code evaluation procedure to the DBE load level is estimated to correspond to a $10 \%$ probability of unacceptable performance for the SDBE. Consequently, ZPAs estimated by code criteria should be scaled up by a factor Ss $=1.5$ to reflect the inherent conservatism on code practice with seismic loading. Since the simple procedure herein omits strength reduction factors, Ss is modified to 1.35. Any use of the resulting maximum acceptable accelerations for comparison with an acceptable DBE should be reduced by a factor of 1.5 before the comparison.

The vertical acceleration is taken equal to the horizontal acceleration. Modal and directional combinations are considered only if necessary in the analyst's judgement. Typically, a fundamental mode excited by only one direction of loading will dominate the structural response.

Part of the 1020-94 procedure includes inelastic capacity factors which reduce the demand for the more ductile failure modes. In the case of reinforced concrete structures, they range from 1.0 for out-of-plane shear to 1.75 for flexure. The use of these factors is predicated on adequate detailing, i.e., proper design of the reinforcing steel components per current code requirements.

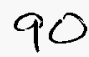


Detailing checks and evaluations of shortfalls are out of the work scope, so the capacity factors are taken as unity in accordance with 1020-94. This indicates, however, that substantial gains could be obtained with additional work.

Seismic pressures on plane walls are estimated with the elastic method characterized by Figure 3500-1 of ASCE 4-86, attached. This approach is considered conservative, and refinements would require soil-structure interaction (SSI) analyses which can be involved. Most calculations herein simplify the figure to $\sigma_{2}^{o}=1.15 \gamma H$. The depth $H$ is 1 imited to the pit floor in situations where the pit is situated over a caisson. The depth $H$ extends down to the foundation in cases where the plane wall extends down to the foundation as well, e.g., 244-CR. Treatment of a caisson under a pit or a cylindrical underground structure is based on experience with the MWTF analysis which was conducted with a ZPA of $0.38 \mathrm{~g}$. A check of the MWTF report shows that the wall's shear stress from SSI analysis is half the stress obtained by multiplying the best estimate free field soil strain at maximum depth by the concrete shear modulus. The curve of free field shear strain vs depth is attached. In-plane shear stresses. obtained in this manner are compared with normal code allowables without amplification to find the acceptable ZPA.

Cover blocks and similar structures not enclosed in soil are amplified for dynamic effects by a factor of two. This includes domed structures with a soil depth that is small compared to the tank diameter. Cover blocks pressing against a wall against soil with horizontal loading are not amplified.

Coincident static soil pressures are estimated with a coefficient $K_{0}=0.4$.

Results are summarized in Table 4.1 along with the maximum ZPA and failure mode.

Some directly buried tanks such as 241-ER-311 are shown to collapse without seismic loading, i.e., they were not shown good for static loading alone. As such, the simple analysis procedure could well overestimate the static loading, and refined analysis would be required. In the analyst's judgement, however, the tank volume is small compared to a characteristic soil volume above it, and a significant opening is unlikely.

Pit wall and cover block collapse is assumed to lead to an opening. No further failure sequence evaluated. In the case of the lower wall of 244-CR, a refined analysis might show integrity with static soil loads by considering plate edge restraints and distribution of moments in the wall.

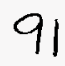


WHC-SD-WM-TI-775, Rev. 0

Table 4.1 Seismic Summary

\begin{tabular}{|l|l|l|l|}
\hline Item & ZPA, g & Failure Mode & Opening \\
\hline \hline $241-A-201 A$ & $>1.0$ & & No \\
\hline $241-A-417$ & 0.60 & $\begin{array}{l}\text { Roof/soil collapse } \\
\text { Pit wall collapse }\end{array}$ & Yes \\
\hline $241-A X-152$ & 0.35 & Pit wall collapse & Yes \\
\hline $241-A Z-151$ & 0.38 & Pit wall collapse & Yes \\
\hline $241-$ ER-311 & 0.00 & Collapse & No - buried deep \\
\hline $241-$ EW-151 & $>1.0$ & & No \\
\hline $241-T X-302 C$ & 0.32 & Collapse & No - buried deep \\
\hline $241-U X-302 A$ & $>1.0$ & & No \\
\hline $241-U-301-B$ & $>1.0$ & & No \\
\hline $241-A-350$ & $>1.0$ & & No \\
\hline $244-A$ & 0.82 & Pit wall collapse & Yes \\
\hline $244-B X / T X / U$ & 0.39 & Pit wall collapse & Yes \\
\hline $244-C R$ & 0.00 & $\begin{array}{l}\text { Lower wall collapse, } \\
\text { refined static analysis } \\
\text { required }\end{array}$ & Yes \\
\hline $244-S$ & Cover blocks collapse & Yes \\
\hline $241-S-304$ & 0.60 & Caisson roof collapse & Yes \\
\hline $200-S$ & 0.48 & Roof collapse & Yes \\
\hline
\end{tabular}


mum relative dynamic movement between anchor points (such as a building attach ment point) and the adjacent soil, which occurs as a result of the dynamic response of the anchor point, shall be calculated. In calculating maximum forces and strains in the buried structure, the motion of adjacent anchor points shall be considered to be out-ot-phase, so as to resul in an absolute sum determination of the relative displacements.

(b) Forces and strains associated with the relative movement of anchor points shall be combined with the corresponding forces and strains from wave propagation effects using the SRSS method.

\subsubsection{Earth-Retaining Walls}

3.5.3.1 General Requirements. (a) Earth-retaining walls shall be analyzed for seismic-induced soil pressures using an elastic solution, unless wall dis placements can be tolerated without loss of wall function in order to justify the use $D$ of an active earth pressure solution.

(b) For cantilever retaining walls, the $N$ active solution may be used.

(c) The summation of the calculated dynamic seismic soil pressures and the static earth pressure shail not exceed the soil static passive earth pressure.

3.5.3.2 Elastic Solution-- Acceptable procedures to determine seismic loads on carth-retaining walls are as follows:

1. Dynamic finite-element analyses that conform to the requirements in 3.3.3 may be used. However, soil-structure connectivity shail be assumed over the entire embedment height, and the effect of structure-structure interaction on dynamic soil pressures shall also be considered.

2. When there is no significant struc ture-structure interaction, a conservative estimate of dynamic soil pressures may be obtained from Fig. 3500-1, and the corresponding resultant force and overturning moment may be obtained from Fig. 3500-2.

3.5.3.3 Active Solution-- The Mononobe-Okabe approach may be used to eslablish dynamic soil pressures, provided that wall displacements required to develop the active earth oressure can
The calculated resultant dynamic force shall be applied at two-thirds of the soil embedment height as measured from the bottom.

\subsubsection{Aboveground Vertical Tanks}

3.5.4.1 General Requirements.. (a) Except as otherwise noted, the requirements set forth in this section are applicable to aboveground vertical, fluidcontaining tanks in which the upper fluid surface is essentially unconstrained (free).

(b) At least two horizontal modes of combined fluid-tank vibration and al least one vertical mode of fuid vibralion shal be included in the analysis.

(c) The horizontal response analysis shall include at least one impulsive mode in which the response of the tank shell and roof are coupled together with the portion of the fluid contents that moves in unison with the shell, and the fundamental sloshing (convective) mode.

3.5.4.2 Horizontal Impulsive Mode

3.5.4.2.1 Effective Weight of Fluid - Impulsive Mode- In the fundamental horizontal impulsive mode, the effective fluid weight (only a portion of the total wcight) shail be determined and used for analyses in lieu of the tolal fluid weight. When determining the effective fluid weight, the tank may be assumed to be rigid.

3.5.4.2.2 Spectral Accelcration-Impulsive Mode-- Damping values to be used to determine the spectral acceleration in the impulsive mode stall be equal to the values for the tank shell material specified in 3.1.2.2.

It is necessary to estimate the fundamental frequency of vibration of the tank including the impulsive fuid weight. Flexibility of the tank shatl be included unless the assumption of a rigid tank can be justified. The horizontal impulsive mode spectral acceleration shall be determined using this impulsive mode tre quency and tank shell damping. in licu of determining the impulsive mode fundamental frequency, it is permissible to use the peak horizontal spectral acceleration for the tank shell damping valuc.

3.5.4.2.3 Overturning Momcnt at Basc of Tank - Impulsive Mode-- The overturning movement at the base of the tank due to the fundamenlal imnulsiue mode shal

NUCLEAR STRUCTURES (ASCE 4-86)

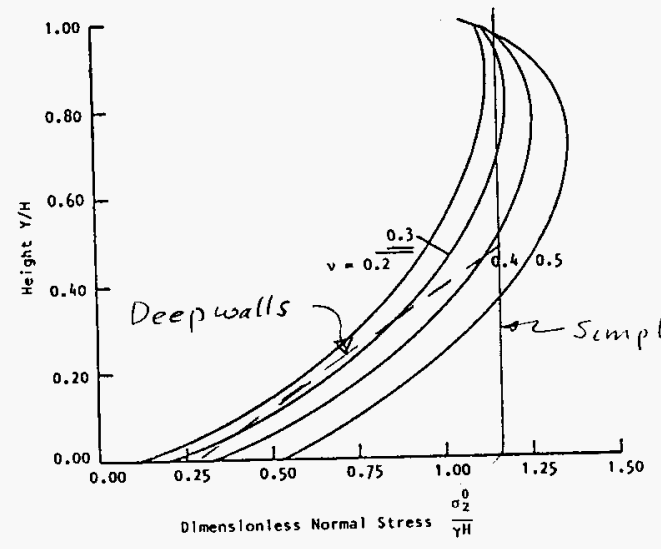

Explanation

$H=\quad$ embedment height

$Y=\quad$ distance from base of relaining structure

$\gamma=\quad$ soil unit weight

$y=\quad$ Poisson's ratio

$0_{2}^{0}=\quad$ lateral dynamic soil pressure against the relaining structure for $1.0 \mathrm{~g}$ horizonla! narthy. acceleration

FIGURE 3500-1 VARIATION OF NORMAL DYNAMIC SOIL PRESSURES FOR TIE HLA SOLUTION

effective fluid weight and the effects of the weight of the tank shell acting in phase. 3.5.4.2.4 Hydrodynamic Pressurc on Tank Shell - Impulsive Mode-- The effect of tank shell flexibility shall be included when determining the hydrodynamic pressure on the lank shell for the impulsive mode.

3.5.4.3 Horizontal Sloshing (Convective Mode)

3.5.431 Effection Weight of Finid - Slosit ing Mode-- The effective fluid weight acting in the horizontal sloshing mode may be determined on the basis of an assumed rigid tank.

3.5.4.3.2 Syectral Acclcration - Sloshims Mode-- In delermining the spectral accelMode-- In determining the spectral accethe fluid damping shall be taken as $0.5 \%$ of critical damping unless a higher value can be substantialed. The fundamental mode may be determined on the basis an assumed rigid tank shell. The horiz: tal sloshing mode spectral acceleralic shall be determined using the slusthi: mode fundamental frequency and dar ing ratio.

3.5.4.3.3 Ovcrlurning Moment af Brot Tank - Sloshing Modc-- The overiurs? moment at the base of the tank duc to fundamental sloshing mode shall determined.

3.5.4.3.4 Ilydrodynamic Pressure on T Shell - Slushiug Mods- The hydrocing

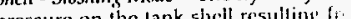
pressure on the lank shell resulting be delermined on the basis of and dssun! rigid tank shell.

3.5.4.3.5 Fluid Slo.h licight - Iutrdin lad Sloshing Mode- The fluid slosh la may be determined based upon 


\begin{tabular}{|c|c|c|c|c|}
\hline Client & Westinghouse Hanford $\mathrm{Co}$. & WO/Job & W236A & \\
\hline Subject & SHAKE Analysis $200 \mathrm{E}$ and $200 \mathrm{~W}$ Areas & Date & $1-11-95$ & GR Wagenblast \\
\hline & & Checked & $2-27-95$ By & C.K. Wonar \\
\hline Location & $200 \mathrm{E} / 200 \mathrm{~W}$ & Revised & By & \\
\hline
\end{tabular}

$241-A-417$

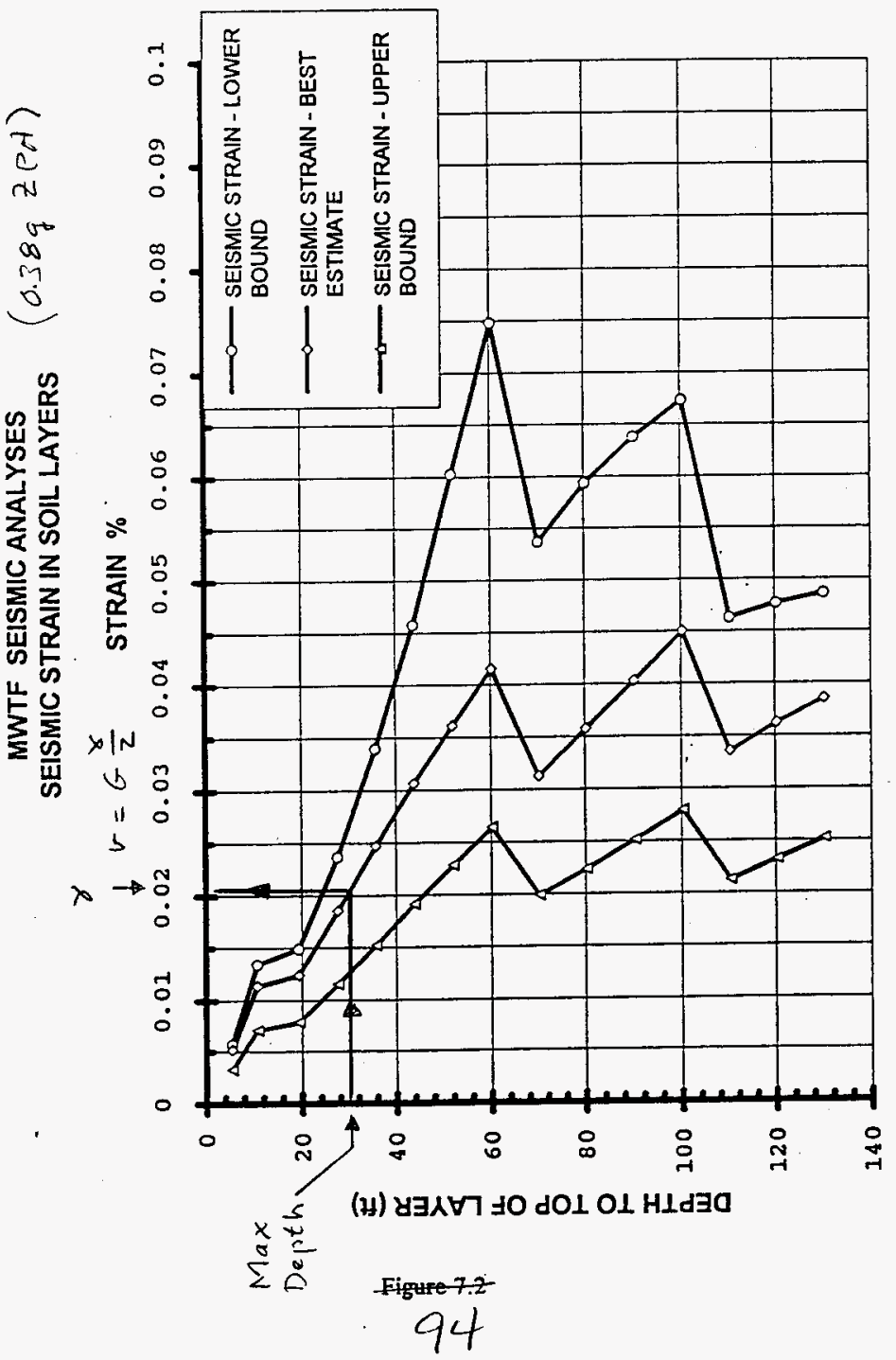




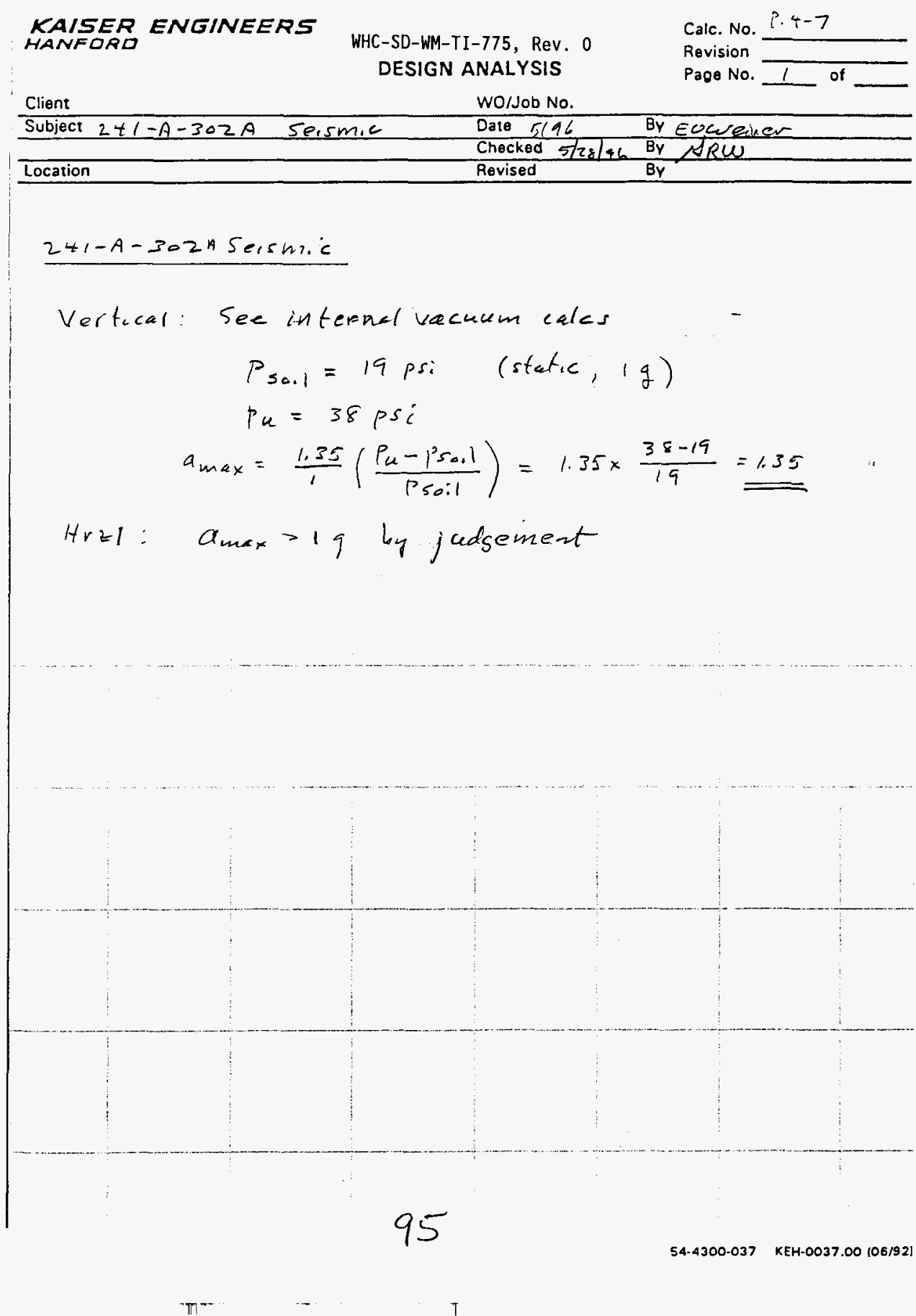


KAISER ENGINEERS

HANFORD
WHC-SD-WM-TI-775, Rev. 0

DESIGN ANALYSIS
Calc. No.

Revision

Page No. 2 of

\begin{tabular}{l} 
Client \\
Subject: \\
\hline Location \\
Seism 6 \\
$241-A-417$
\end{tabular}

Vert: Cover blts. See uniform load calls (App 1)

$$
\begin{aligned}
& p_{\text {live }}=1.0 \mathrm{ksf} \text { (acceptable live loo) } \\
& h=2.2^{\prime} \\
& \text { In: Press }=\gamma_{\text {con }} h=.15 \text { hel } \times 2.5^{\prime}=.375 \text { toss } \\
& a_{\text {max }}=\frac{S_{s}}{A} \frac{P_{\text {In }}}{P_{\text {leis }}}=\frac{1.35}{2} \cdot \frac{1.0}{.375}=1.8 \mathrm{~g}
\end{aligned}
$$

Caisson roof under soil:

see int. vac. call: $\quad P_{\text {soil }}=12$ psi $M_{n}=23^{K} \quad L=7.5^{\prime}$

$$
\begin{aligned}
M & =\frac{P L^{2}}{8}=\frac{12 p s \times(7.5 \times 12)^{2}}{8}=12.2^{\mathrm{K}} \\
a_{\text {max }} & =\frac{S_{5}}{A} \quad \frac{M_{n}-M}{M}=\frac{1.35}{2} \frac{25-12.2}{12.2}=0.60 \mathrm{~g}
\end{aligned}
$$

Herzl:

Cover blts wall, inertial load of blocks puts well in bending shear.

$$
\begin{aligned}
& b=\text { blkdepth }+\frac{1}{3} \text { (unblocked wall) } \\
& =2 \times 15^{4}+\frac{1}{3}\left(14.5^{\prime}-2.5\right)=6.5^{\prime} \\
& h_{\text {ave }}=\left(10.5^{11} \times 1.25+14.5^{11} \times 1.25-10 \times\right. \\
& \begin{array}{r}
\left.\quad+18^{\prime \prime} \times 4.5\right) / 6.5=16^{\prime \prime} \\
\text { lv }=25^{\circ} \quad d=16-1.5=14.5^{\prime \prime}
\end{array} \\
& \begin{array}{c}
\left.\quad+18^{\prime \prime} \times 4.8\right) / 6.5=16^{\prime \prime} \\
c l v=25^{\circ} \quad d=16-1.5=14.5^{\prime \prime}
\end{array} \\
& \text { *5e14 EFEW } j=.95 \\
& m_{n}=j d \frac{A b}{5} f_{y}=.45 \times 14.5^{\prime \prime} \times \frac{.31^{11}}{14} \times 40^{k S_{i}}=12.2^{\mathrm{K}}
\end{aligned}
$$$$
\bar{q}
$$$$
H=\left(4 . x^{\prime}\right.
$$

$T$ 


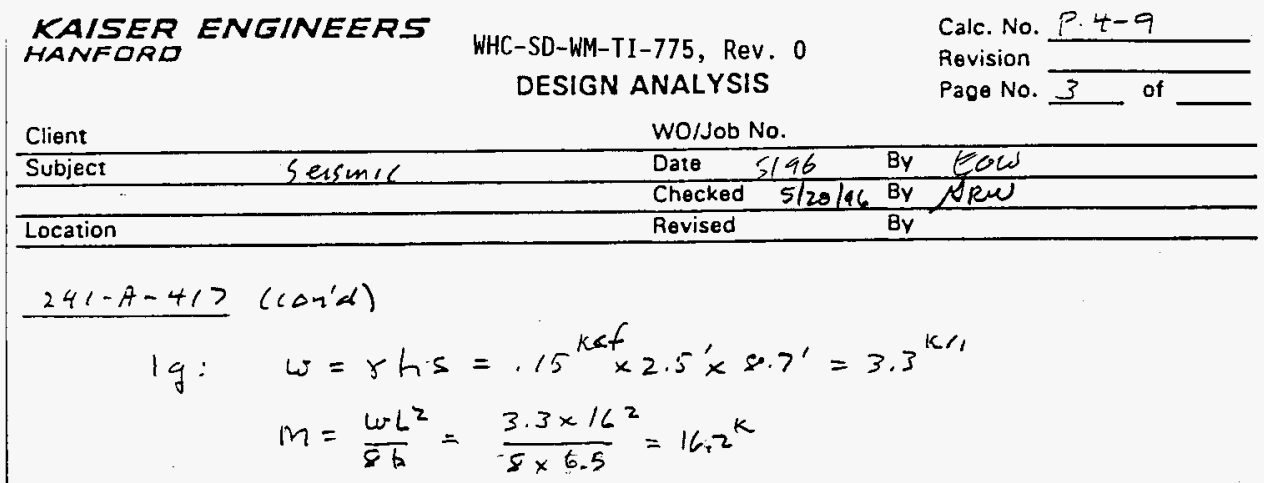

So .1 resistance per UBC Table 29-B

$$
\begin{aligned}
& P_{\text {so.1 }}=150 \text { pst }\left(1+\frac{1}{2}\right)=230 \text { psf (ave at blk) } \\
& w_{\text {so. }}=p_{\text {so. }} h=.23^{\mathrm{kst}} \times 2.5^{\prime}=0.6^{\mathrm{k} /} \\
& M_{50: 1}=\frac{\omega_{50: 1}}{\omega_{0}} M=-\frac{0.6}{3.3} 16.2^{\mathrm{K}}=3.0^{\mathrm{k}} \\
& a_{\text {max }}=\frac{-S_{s}}{A} \frac{M_{n}+M s_{0: 1}}{M}=\frac{1.35}{1} \frac{12.2+3.0}{16.2}=1.3 \mathrm{~g} \\
& V_{n}=2 \sqrt{ } f_{L} d b=110 \text { psi } \times 14.5^{4} \times 6.5 \times 12^{\prime \prime}=124^{k} \\
& V \approx \omega L / 2=3.3^{k / 1} \times 16^{\prime} / 2=26^{k} \text { (dues not control) }
\end{aligned}
$$

Pitwall:

$$
\begin{aligned}
H=14.5^{\prime} & P_{\text {ser }}=1.15 \gamma 1 \mathrm{H}=.125 \mathrm{kct} \times 14^{\prime}=2.8 \mathrm{kst} \\
& P_{\text {soil }}=k_{0} \gamma_{\text {i }} H_{\text {eve }}=0.4 \times .125 \times 7=.35 \mathrm{kst}
\end{aligned}
$$

wall is simply supported all around

Rourke $4^{\text {th }}$ Tale $X .36 \quad a=16^{\prime} \quad b=13.3^{\prime}$

$$
\begin{aligned}
& a / 6=16 / 13.3=1.2 \quad \beta=.376 \\
& M=\frac{t^{2}}{6} 5=\frac{\beta}{6} p b^{2}=\frac{376}{6} \times 270125+13.3^{2}=22.1^{k} \\
& d=16.5 \quad m_{n}=\frac{16.5}{14.5} 12.2^{\mathrm{K}}=13.9^{\mathrm{K}} \\
& \text { Q seemnabove } \\
& m_{\text {sol }}=\frac{\text { soil }}{\text { Press }} M^{i=1}=\frac{.35}{12.0} \times 2.2=3.9 \mathrm{k} \\
& 97 \quad 54.4300-037 \quad \text { KEH-0037.00 106/921 }
\end{aligned}
$$




$$
\begin{aligned}
& \text { KAISER ENGINEERS } \\
& \text { WHC-SD-WM-TI-775, Rev. } 0 \\
& \text { Call. No. } P \cdot t-10 \\
& \text { DESIGN ANALYSIS } \\
& \text { Revision } \\
& \text { Page No. } 4 \text { of } \\
& \text { WO/Job No. } \\
& \text { Client } \\
& \text { Date } 5146 \text { By EOH } \\
& \text { Checked } 5 / 28 / 96 \text { By Afrew } \\
& \text { Location } \\
& \text { Revised } \\
& \text { By } \\
& 241-A-417 \text { (contd) } \\
& a_{\text {max }}=\frac{s_{5}}{A} \frac{m_{n}-m_{0}}{m}=\frac{1.35}{1} \frac{13.9-3.9}{.22}=.61 \mathrm{~g} \\
& \text { Depth } H_{\text {max }}=30^{\prime} \text { Mut } \gamma=0.0219 \\
& v=G \gamma / 2=1.3 e 6 \times \frac{220}{2}<C=140 \mathrm{psi} \\
& v_{c}=2 \sqrt{f_{c}}=110 p^{s_{i}} \\
& \text { Herzl steel }=\$ 5 \mathrm{e} / \text { "aF } \quad d=0.8 \mathrm{~h}=0.8 \times 10^{\prime \prime}=8 \text { " } \\
& v_{s}=\frac{A_{s} f_{s}}{s_{2} d}=\frac{0.311^{2} \times 40 \mathrm{ki}}{11 \times 8}=140 \text { phi } \\
& v_{n}=v_{c}+v_{j}=110+140=250 p e: \\
& a_{\max }=\frac{S_{s}}{A} a_{0} v_{n}=\frac{1.35}{1} 0.38 \frac{250}{140}=\underline{0.92 \mathrm{~g}}
\end{aligned}
$$

98

54-4300-037 KEH-0037.00 106/9: 
KAISER ENGINEERS

HANFORD
WHC-SD-WM-TI-775, Rev. 0

DESIGN ANALYSIS
Talc. No. P. $t-11$

Revision

Page No. 5 of

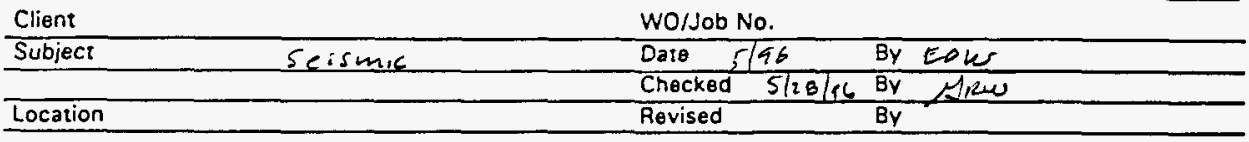

$241-A x-1525 e r s m i c$

Vertical:

Cover blocks: $P_{\text {live }}=11$ hst (App 1) $h=5^{\prime} 8^{\prime \prime}$ start, ok

Mra:

Cover blocks (H-2-445FI Sect E)

Wall ht $=10^{\prime} 6^{\prime \prime}+1^{\prime} 5^{*}+4^{\prime} 1^{4}=16^{\prime}$

Use $1 / 3$ wall below blocks

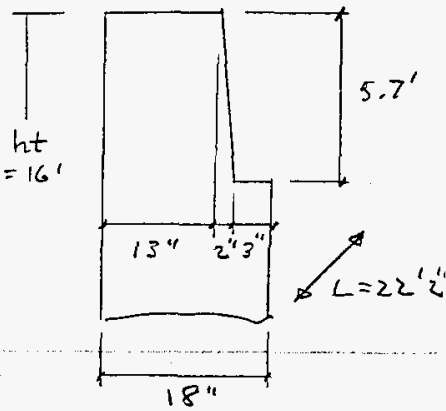

$b=5.7+\frac{1}{3}(16-5.7)=9.1^{\prime}$

$h_{\text {ave }}=\frac{14^{\prime \prime} \times 5.7+15^{\prime \prime} \times(9.1-5.7)}{7.1}=15.5^{\prime \prime}$

cir $=2 \% \quad d=13.5^{\circ}$

*6 e $12^{*} j=.95$

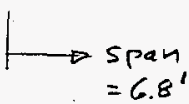

$M_{n}=.95 \times 13.5 \times \frac{144}{12} 40=18.8^{K}$ $=6.8^{\prime}$

lg:

$$
\begin{aligned}
& \omega=\gamma h s=.15^{k \mathrm{kf}} \times 5.7^{\prime} \times 6.8^{\prime}=5.8^{\mathrm{K} / 1} \\
& M=\frac{\omega L^{2}}{8 b}=\frac{5.8 \times 22.2^{2}}{8 \times 9.1}=39^{\mathrm{K}}
\end{aligned}
$$

Soul resistance UBC table 29-B

$$
\omega_{\text {soil }}=150 \text { pr f }(1+4 . \bar{i} 12)
$$$$
\omega_{\text {so it }}=500 \text { psf }
$$$$
M_{\text {sol }}=\frac{.5}{5.6} 39^{k}=3.4^{k}
$$$$
a_{\text {max }}=\frac{s_{s}}{A} \frac{m_{n}+M_{s 0.1}}{M}=\frac{1.35}{1} \cdot \frac{18.8+3.4}{39}=0.77 \mathrm{~g}
$$

Lower wall:

$$
\begin{aligned}
& H=681-652=29^{\circ} \quad P=.75 \times 1 t \\
& P=0.75 \times .125 \times 29=2.7 \mathrm{ksf} \\
& 99
\end{aligned}
$$

$\pi_{i}^{-\cdots}$

$T$ 
KAISER ENGINEERS

HANFORD ENGINEERS WHC-SD-WM-TI-775, Rev. 0
Call. No. P. 4-12

Revision

Page No. 6 of

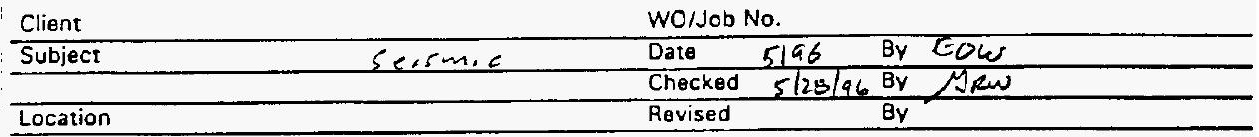

$$
\begin{aligned}
& 241-A x-152 \text { (cons) } \\
& P_{\text {so.1 }}=K_{\text {orltave }}=0.4 \times .125 \times(29-1.5-11.5 / 2)=1.11256 \\
& \text { Route } 4^{t} \text { Table X. } 3 c: b=11.5^{\prime} \quad a=22.2^{\prime} a / b=2
\end{aligned}
$$

$$
\begin{aligned}
& \beta=.610 \\
& M=\frac{\beta}{6} p b^{2}=\frac{.61}{6} \times 2.7 \times 11.5^{2}=36^{k} \\
& m_{S_{0.1}}=\frac{1.1}{2.7} 36=14.7 \mathrm{k} \\
& H_{6 Q 10^{\circ}} d=18-2=16^{4} \\
& M_{n}=.95 \times 16 \times \frac{.44}{10} \times 40=26.7^{\mathrm{K}} \\
& a_{\max }=\frac{1.35}{1} \frac{26.7-147}{36}=0.45 \mathrm{~g}
\end{aligned}
$$

Upper wall

$$
\begin{aligned}
& p_{\text {sets }}=1.158 H_{\text {max }}=1.15 \times .125 \times 29=4.2 \mathrm{ksf} \\
& P_{50.1}=0.4 \times .125 \times 11^{\prime \prime}=.551256 \\
& a=14.7^{\prime} b=10.5+1.5+4.1-5.7=10.4^{\prime} \\
& a / 6=14.2 / 10.4=1.4 \quad \beta=0.45 \\
& M=\frac{\beta}{6} P_{\text {ers }} b^{2}=\frac{.45}{6} \times 4.2 \times 10.4^{2}=34^{k} \\
& m_{\text {so: }}=\frac{.55}{4.2} 34=4.5 \mathrm{k} \\
& \text { " } 6 \text { e } 20^{\prime \prime} \quad d=18-2=16^{\prime \prime} j=.95 \\
& m_{n}=.95 \times 16 \times \frac{.44}{20} \times 40=13.4^{\mathrm{k}} \\
& a_{\text {max }}=\frac{1.35}{1} \frac{13.4-4.5}{34}=0.35 \mathrm{~g} \\
& -100 \text { - }
\end{aligned}
$$




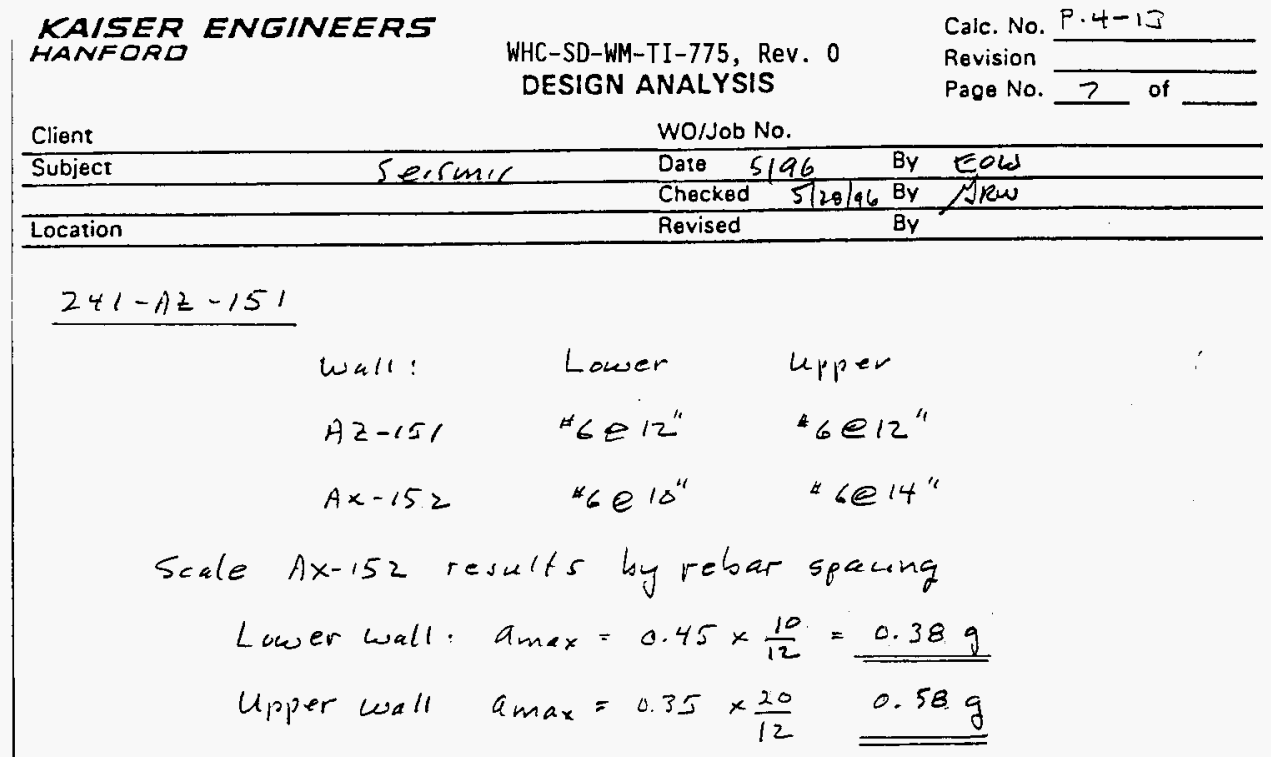




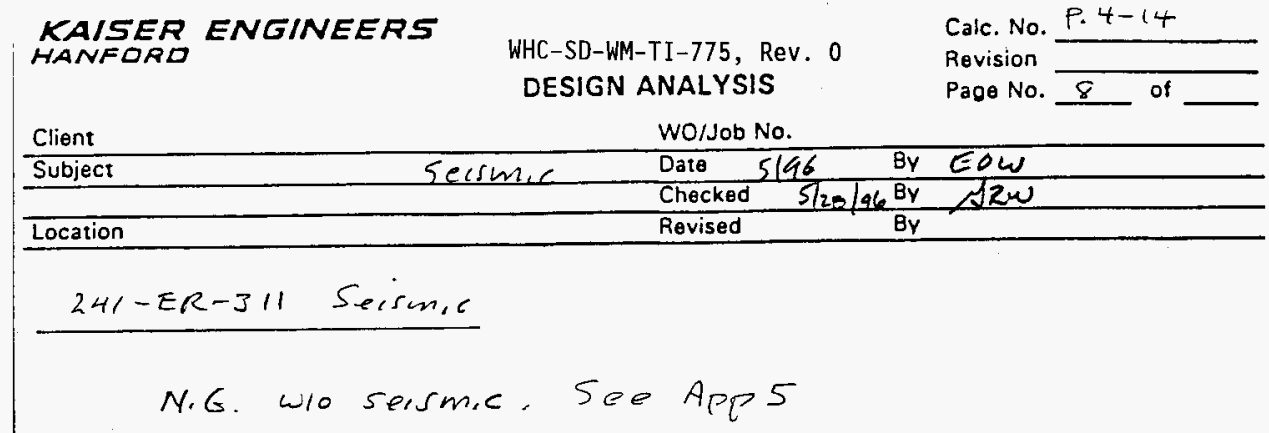

102

$54-4300-037 \quad \mathrm{KEH}-0037.00106 / 9$ 
$\underset{\text { HANFORD }}{\text { KAISER ENGINEERS }}$

WHC-SD-WM-TI-775, Rev. 0 DESIGN ANALYSIS

Client

Subject

WO Job No.

Date 5146

Calc. No. $\because 4-15$

Revision

Page No. $\bar{q}$ of

Location

Checked

On

Revised

$5 / 2 0 \longdiv { 4 6 }$

BY

$2+1-E \omega-151$ seism

Vert: Cover blts live $=2.1$ list (App 1) $h=2$ '

lg: $P_{\text {jed }}=h \gamma=2 \times .15=.3$ hst $<2.1$ ks $\Rightarrow$ stout

Hut:

Carer bl ks

$$
\begin{aligned}
& b=2^{\prime}+\frac{1}{3}\left(5.2-2^{\prime}\right)=3.2^{\prime} \\
& h_{\text {ave }}=\left(2 \times 6.5^{\prime \prime}+1.2 \times 12^{\prime \prime}\right) / 3.2 \\
& =8.6 \% \\
& c l v=2 " d=6.6 " \text { "6el2 } j=.95 \\
& m_{n}=.95 \times 6.6 \times \frac{744}{12} \times 40=9.2^{\mathrm{k}} \\
& \text { In: } w_{\text {sets }}=\gamma h s=1.5 \times 2.0 \times 7=2.1^{\mathrm{k} / 1} \\
& M_{\text {sec }}=\frac{\omega L^{2}}{86}=\frac{2.1 \times 8^{2}}{8 \times 3.2}=5.3^{K}
\end{aligned}
$$
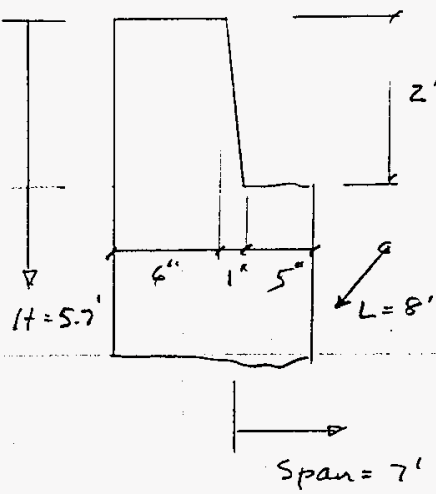

Lower wall: $a=b=8.31 \quad \beta=.287$

$$
\begin{aligned}
& H_{\text {ave }}=16.5-1.2-4.2=11.11 \\
& P_{\text {soil }}=K_{0} \gamma L t= 14 \times .125 \times 11.1=.56^{\mathrm{ks} f} \\
& 103 \quad
\end{aligned}
$$




$$
\begin{aligned}
& \text { KAISER ENGINEERS } \\
& \text { WHC-SD-WM-TI-775, Rev. } 0 \\
& \text { Calc. No. P. } 4-16 \\
& \text { DESIGN ANALYSIS } \\
& \text { Revision } \\
& \text { Pago No. } 10 \text { of } \\
& \begin{array}{|l}
\text { Client } \\
\hline \text { Subject } \\
\hline \text { Location }
\end{array} \\
& \text { Wo/Job No. } \\
& 241-E \omega-151 \text { (con'ch) } \\
& H_{\text {minex }}=16.5^{\prime} \\
& p_{\text {se.s }}=0.8 \% 1 t=0.8 \times .125 \times 16.5=1.65 \mathrm{kst} \\
& \text { "Ge12 } h=12 \text { " } d=10 " j=.95 \\
& m_{n}=.95 \times 10 \times \frac{.44}{12} \times 40=13.9 \mathrm{~K} \\
& M_{\text {seis }}=\frac{\beta}{6} p b^{2}=\frac{.287}{6} \times 1.65 \times 8.3^{2}=5.4^{\mathrm{K}} \\
& M_{50.1}=\frac{.56}{1.65} \times 5.4=1.8^{\mathrm{K}} \\
& a_{\text {max }}=\frac{S_{5}}{A} \cdot \frac{M_{n}-M 50.1}{M_{50.5}}=\frac{1.35}{1} \frac{13.9-1.8}{5.4}=3.0 \mathrm{~g}
\end{aligned}
$$

104

54-4300-037 КЕH-0037.00 106/92 
KAISER ENGINEERS

WHC-SD-WM-TI-775, Rev. 0 DESIGN ANALYSIS
Calc. No. P. 4-17

Revision

Page No. 11 of

\begin{tabular}{l} 
Client \\
\hline Subject \\
\hline Location \\
$241-T \times-3020$ Secsm.e
\end{tabular}

See APP 5: $\quad P_{\text {soul }}=33-8=-25$ psi $\quad P_{k}=31 p^{5:}$

$$
\text { vert: } a_{\max }=\frac{S_{s}}{A} \cdot \frac{P_{u}-P_{\text {soil }}}{P_{5 a .1}}=\frac{1.35}{1} \cdot \frac{31-25}{25}=0.32 \mathrm{~g}
$$

105

54.4300-037 KEH-0037.00 106/92 


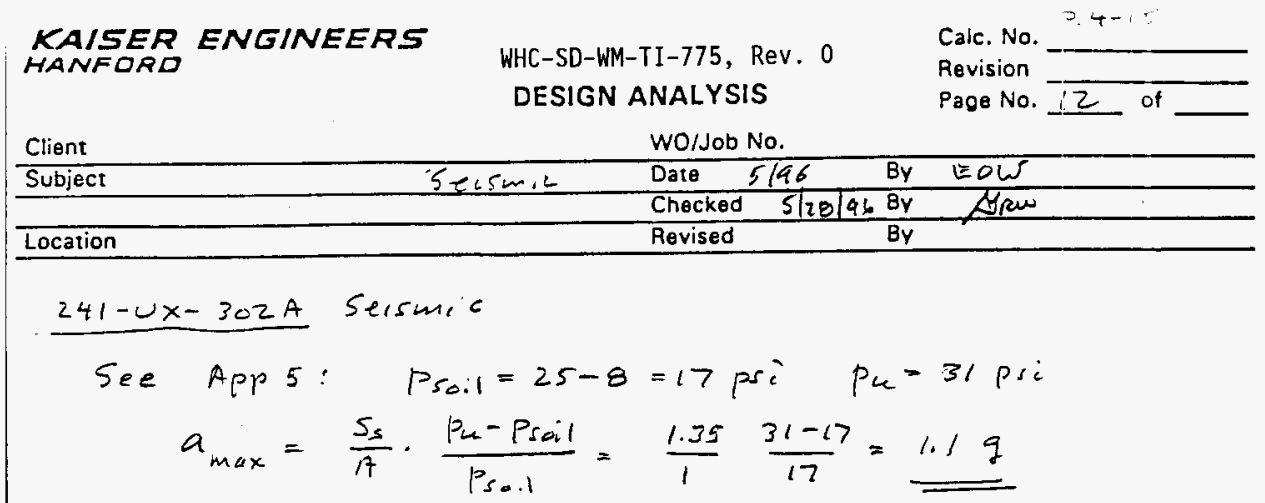


KAISER ENGINEERS

HANFORD

Client

Subject
WHC-SD-WM-TI-775, Rev. 0

DESIGN ANALYSIS
Call. No. P. $4-19$

Revision

Page No. 13 of

Location

WO/JOb No.

Se.rmuc

Date 5/96 By Low

Revised By

$241-0-301-3$ seismic

Vert: sec App 5 internal vacuum for dome

$$
\begin{aligned}
& p_{\text {cap }}=27 \text { psi } \\
& p_{\text {sal }}=6.3 \text { psi } \\
& a_{\text {max }}=\frac{5 \text { s }}{A} \frac{p_{\text {cap }}-p_{\text {so. }}}{P_{\text {sol }}}=\frac{1.35}{2} \quad \frac{27-6.3}{6.3}=2.2 \mathrm{~g}
\end{aligned}
$$

Itrzl:

Wall: steel: vert $\# 4$ e $12^{\prime \prime}$

$v_{s}=\frac{f_{y} A_{b}}{s_{2} d} \quad h=6^{4} \quad d=0.8 \mathrm{~h}=4.8^{\prime \prime}$

With ural steel: $v_{s}=\frac{40^{k s i} \times 4.2 \mathrm{in}^{2}}{9^{\prime \prime} \times 4.6^{\prime \prime}}=185 \mathrm{psi}$

$$
\begin{aligned}
& v_{c}=2 \sqrt{f_{c}^{\prime}}=110 \mathrm{pos}_{\mathrm{i}} \\
& v_{n}=v_{c}+v_{s}=295 \mathrm{psi} \\
& 1 t_{\text {max }}=18+6+2.5=26 . \mathrm{s}^{\prime}
\end{aligned}
$$

MUTE $8=0.01790$

$$
\begin{aligned}
& G=G \times / 2=1.3 e 6 p 5 . \times \frac{.017}{100 \times 2}=110 \mathrm{Cs}^{5} \\
& a_{\text {max }}=1.35 \times 0.38 \times \frac{295}{110}=1.4 \mathrm{q}
\end{aligned}
$$

107

54-4300-037 KEH-0037.00 106/92 
KAISER ENGINEERS

HANFORD
WHC-SD-WM-TI-775, Rev. 0

DESIGN ANALYSIS
Calc. No. P. 4-20

Revision

Page No. it of

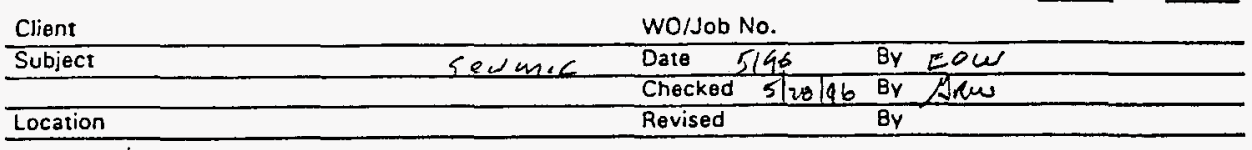

$241-A-350$ Secsurc

Vert: See App 1: olive $=2.1$ las $h=1.7$

$$
\begin{aligned}
& \text { lg: Psis }=8 h=.15 \times 1.7=.26 \text { hst } \\
& a_{\text {max }}=\frac{1.35}{2} \frac{2.1}{.26}=5.5 \mathrm{~g} \quad \text { (Cover blocks) }
\end{aligned}
$$

Ho $\& 1:$

Cover blocks \& wall

$$
\begin{aligned}
b & =1.7^{\prime}+\frac{1}{3}\left(11-1.7^{\prime}\right)=4.8^{\prime} \\
h_{\text {ave }} & =\left(1.7 \times 7.5^{\prime \prime}+3.1 \times 12^{\prime \prime}\right) / 4.8 \\
& =10.4^{4}
\end{aligned}
$$

$45 e 12^{4} j=.95^{\circ} \quad 1.5^{\prime \prime} \operatorname{clr}^{\prime} \quad d=8.9^{4}$

lg: $\omega_{\text {sea }}=.15 \times 1.7 \times 10=2.6^{\mathrm{k} / 1}$

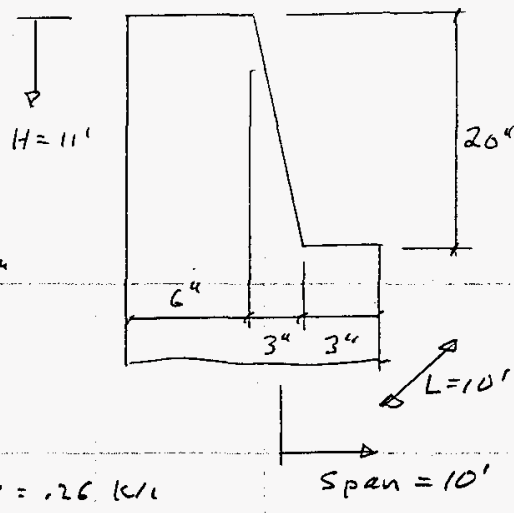

$P_{\text {sol }}=150$ pst $\quad \omega_{\text {sol }}=.15 \times 1.7=.26 \mathrm{k} / \mathrm{l}$

Span $=10^{\prime}$

$M_{\text {sol }}=\frac{.26}{2.6} \times 6.8=0.7^{k}$

$m_{n}=j d \frac{7 A_{6}}{5} f_{y}=.95 \times 8.9 \times \frac{.31}{12} \times 40=8.9 \mathrm{k}$

$a_{\text {max }}=\frac{S_{s}}{A} \frac{M_{n+M}+M_{\text {sal }}}{M_{\text {sets }}}=\frac{1.35}{1} \cdot \frac{8.9+.7}{6.8}=1.9 \mathrm{~g}$

Upper wall:

Have $=\frac{10.5}{2}=5.2^{\prime} \quad P_{\text {soil }}=K_{0} \times H_{\text {ave }}=.4 \times .125 \times 5.2=.26^{\mathrm{kst}}$

Pecs $=1.15 \gamma H_{\text {max }}=1.15 \mathrm{f.125 \times 10.5}=1.51 \mathrm{ksf}$

Square wall $a=b=10^{\circ}$

108

$54 \cdot 4300-037$ KEH-0037.00 106/921 
KAISER ENGINEERS
HANFORD
WHC-SD-WM-TI-775, Rev. 0

DESIGN ANALYSIS
Cali. No. $p-4-21$

Revision

Page No. 15 of

$\begin{array}{ll}\text { Client } & \text { Wo/Job No. } \\ \text { Subject } & \text { Date }\end{array}$

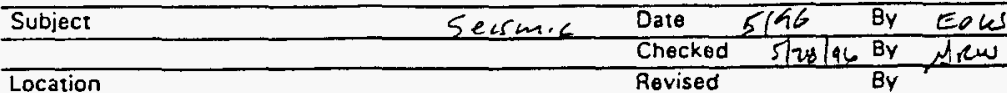

$241-A-350$ Seismic

$$
\begin{aligned}
& M_{\text {seas }}=\frac{.287}{6} \times 1.51 \times 10^{2}=7.2^{k} \quad M_{\text {sol }}=\frac{.26}{1.51} \times 7.2=1.2^{\mathrm{k}} \\
& { }_{5012^{\prime \prime}} h=12^{\prime \prime} 1.5 \% \mathrm{clr} \quad d=10.5^{\prime \prime} \quad j^{\prime}=.95 \\
& M_{n}=.95 \times 10.5 \times \frac{.31}{12} \times 40=10.3^{\mathrm{k}} \\
& a_{m<x}=\frac{1.35}{1} \times \frac{10.3-1.2}{7.2}=1.7 \mathrm{~g}
\end{aligned}
$$

Carson: 12 ga corrugated steel is ductile, judged ok Note: Expect 2 "corrugations, $r=0.69^{\circ}$ (radigyr.)

Per Street Engr Hd bt Chap 29

$$
\begin{aligned}
& \begin{aligned}
\sigma_{\text {allow }}=\frac{30000 p:}{2 k} \quad k & =9020 \text { T.99 stdso.ldens. } \\
& =, 75
\end{aligned} \\
& v_{\text {allow }}=\frac{30000 \text { phi }}{2 \times .75}=20 \mathrm{ksi} \\
& t=109^{\prime \prime}\left(12 g^{4}\right) \quad P_{a l l \Delta w}=\sigma_{a t 10 w} \frac{2 t}{D}=\frac{20^{b i} \times 2 \times 107}{8 \times 12} \\
& \text { tallow }=45 \text { ps: }
\end{aligned}
$$

Lateral sol pressures (static)

Top proil $=0.4 \times .125 \times 12^{\circ}=.6^{\text {ks }}=4$ psi

Bottom $=0.4 \times 125 \times 29^{\circ}=1.5^{\mathrm{ks} f}=16 \mathrm{psi}$

are small composed to fellow $\Rightarrow$ Caisson ok in role to provide confinement for soil supporting pit daring shaking.

109

54-4300.037 KEH.0037.00106/92 
KAISER ENGINEERS HANFORD

$$
\text { WHC-SD-WM-TI-775, Rev. } 0
$$

DESIGN ANALYSIS
Call. No. $1.4-22$

Revision

Page No. $1 \mathrm{c}$ of

$$
\begin{aligned}
& \text { Client } \\
& \hline \text { Subject } \\
& \hline \text { Location } \\
& 244-A \\
& \text { Yerfocel }
\end{aligned}
$$

WO/Job No.

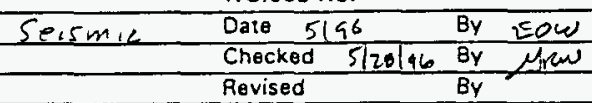

Cover blocks: App 1: olive $=0.67$ last $h=20^{\prime \prime}=1.7^{\prime}$

$$
\begin{aligned}
& \text { lg: psoas }=.15 \times 1.7=.25 \mathrm{ks} \\
& a_{\text {max }}=\frac{1.35}{2} \frac{.67}{.25}=10 \mathrm{~K}
\end{aligned}
$$

Horizontal:

$$
\begin{aligned}
& \text { cover blts \& wat } \\
& \text { \#5 e } 10^{*} \\
& b=1.7^{\prime}+\frac{1}{3}(12-1.7)=1.7+3.4 \quad H=12 . \\
& =5.11 \\
& h_{\text {ave }}=\left(1.7 \times 7.5^{4}+3.4 \times 12^{\prime \prime}\right) / 51=10.5^{\prime \prime} \text {. } \\
& 1.5^{\prime \prime} \operatorname{ctr} \quad d=q^{\prime \prime} \quad j=.95 \\
& m_{n}=.95 \times 9 \times \frac{.31}{10} \times 40=10.6^{\mathrm{K}} \\
& \text { In: } \omega_{\text {leis }}=.15 \times 1.7 \times 13.7=3.5 \mathrm{k} / 1 \\
& M_{\text {read }}=\frac{\omega L^{2}}{86}=\frac{3.5 \times 13^{2}}{8 \times 5.1}=14.5 \mathrm{~K} \\
& P_{\text {sol }}=150 \text { pst } \omega_{\text {sol }}=.15 \times 1.7=.26^{\mathrm{k} / 1} \\
& m_{\text {soul }}=\frac{.26}{3.5} \times 14.5=1.1^{k} \\
& \begin{array}{l}
a_{\text {max }}=\frac{1.35}{1} \cdot \frac{10.6+1.1}{14.5}=1.1 \mathrm{~g} \\
a / 16=1.2 \quad \beta=.376
\end{array} \\
& 45 e 12 \quad d=10.51 . m_{n}=.95 \times 10.5 \times-\frac{31}{12} \times 40=10.3^{K} \\
& \text { Have }=6^{\circ} \quad P_{50.1}=.4 \times .125 \times 6=0.31256 \\
& 110 \quad 54-4300-037 \quad \mathrm{KEH}-0037.00106 / 92
\end{aligned}
$$




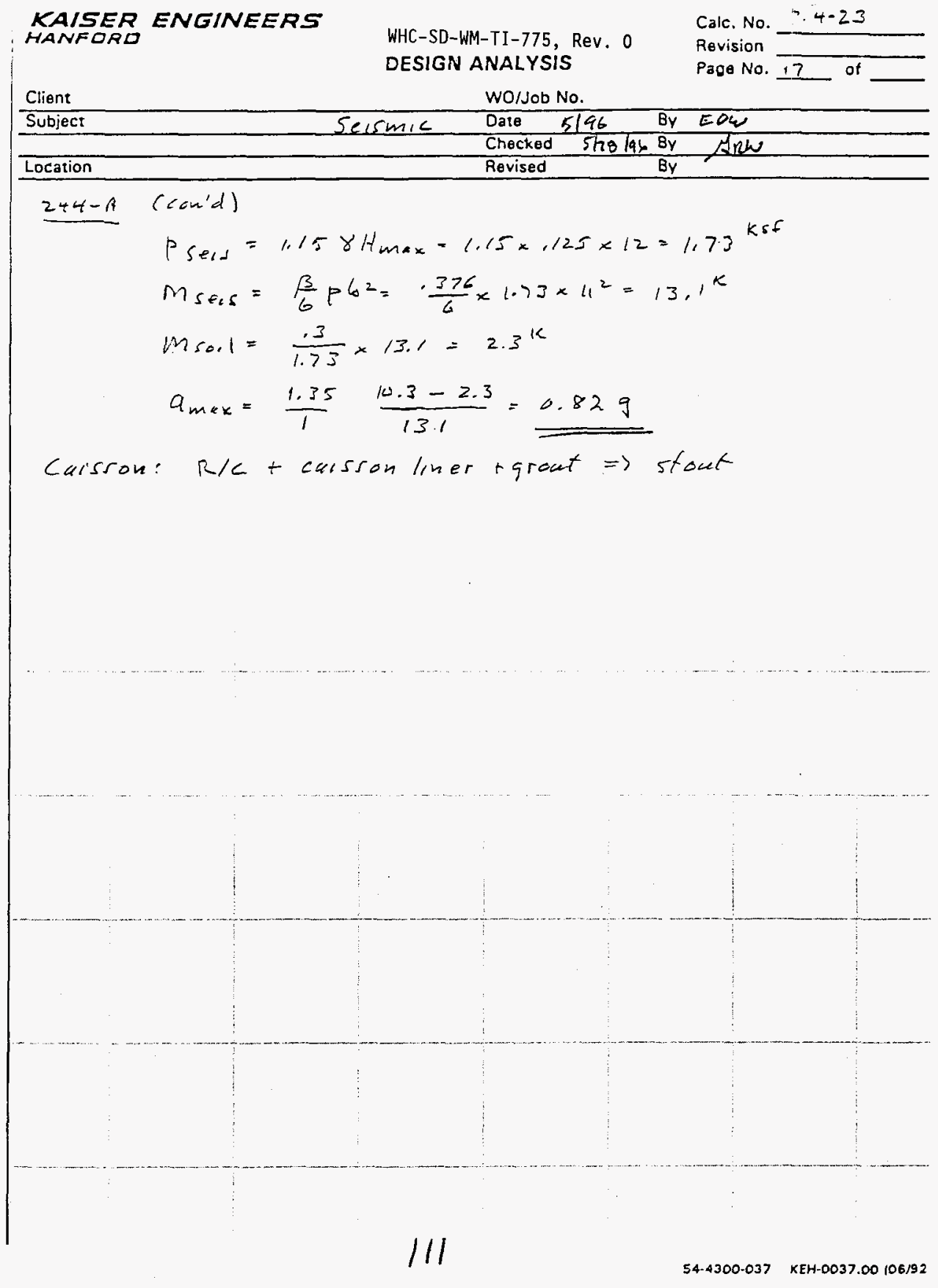


KAISER ENGINEERS HANFORD
WHC-SD-WM-TI-775, Rev. 0

DESIGN ANALYSIS
Gale. No. $P \cdot 4-2+$

Revision

Page No. 18 of

Client
Subject
Location
$244-B \times / 7 \times / 0$

Vertical:

Coverlalocts: App 1: Alive $=1.3$ lest $h=20^{\prime \prime}$

$$
a_{\max }=\frac{1.35}{2} \cdot \frac{1.3}{.15 \times 1.7}=2.5 \mathrm{~g}
$$

Herzl: Coverbltes d wall

$$
\begin{aligned}
& b=2^{\prime}+\frac{101}{3}=5.3^{\prime} \\
& h_{\text {ave }}=(13.5 \times 2+18 \times 3.3) / 53 \\
& \left.=16.3^{\prime \prime} \quad \text { cir }=3 . " d=13\right]^{\prime \prime} \\
& \text { Ht } e \text { in } j=.95 \\
& M_{n}=.95 \times 16.3 \times \frac{.44}{12} \times 60=34 k \\
& \omega_{\text {leis }}=\gamma h s=.15 \times 2.0 \times 17.5=5.3 \mathrm{k} / \mathrm{s} \\
& M_{\text {seas }}=\frac{\omega L^{2}}{8 b}=\frac{5.3 \times 19^{2}}{8 \times 5.3}=45^{-K} \\
& p_{\text {sol }}=.15(1+1 / 2)=.23 \text { kt } \omega_{50.1}=.4 \mathrm{kil} \\
& M_{\text {soil }}=\frac{.4}{5.3} 45=3.4 \mathrm{~K} \\
& a_{\text {max }}=\frac{1.35}{1} \cdot \frac{34+3.4}{45}=1.1 \mathrm{~g} \\
& \text { Upperwall } b=16 \mathrm{cmox}) \quad a=19 \quad a / 6=19 / 16=1.2 \quad \beta=.376 \\
& I_{\text {max }}=37^{\prime} P_{\text {seas }}=1.15 \gamma 1 t=1.15 \times .125 \times 37^{\prime}=5.3 \mathrm{kst} \text {. } \\
& \text { Have }=8^{\prime} \quad p_{50.1}=.4 \times .125 \times 8=.41256 \\
& M_{\text {ser }}=\frac{\beta}{6} P^{2}=\frac{.376}{6} \times 5.3 \times 16^{2}=85^{K} \\
& \begin{aligned}
\text { mso.1 }=\frac{.4}{5.3} \times 85= & 6.4^{k} \\
& 112
\end{aligned}
\end{aligned}
$$

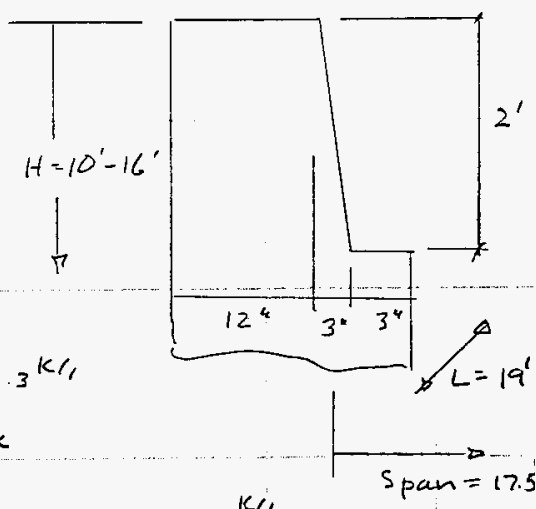


KAISER ENGINEERS

Call. No. P. -25

WHC-SD-WM-TI-775, Rev. 0 Revision

DESIGN ANALYSIS

Page No. 19 of

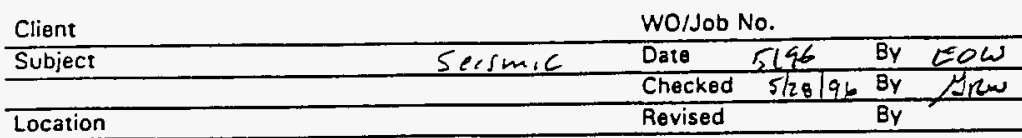

$244-B x / T \times / 2$

$$
\begin{aligned}
& \text { \#ee12 } d=18-3=15^{\prime \prime} \quad m_{n}=.95 \times 15 \times \frac{.44}{12} \times 60=31 \mathrm{~K} \\
& a_{\max }=\frac{1.35}{1} \quad \frac{31-6.4}{85}=0.39 \mathrm{~g}
\end{aligned}
$$

Bottom wall is thicker with $\$ 1106$ dis

113

$54-4300-037 \quad \mathrm{KEH}-0037.00\{06 / 92\}$ 
KAISER ENGINEERS

HANFORD
WHC-SD-WM-TI-775, Rev. 0

DESIGN ANALYSIS
Call. No. P.4-26

Revision

Page No. 20 of

Client WO/Job No.

Subject

Secant

Location

Date 7196 By LoW

Revised

By

$24+\cdot C R$

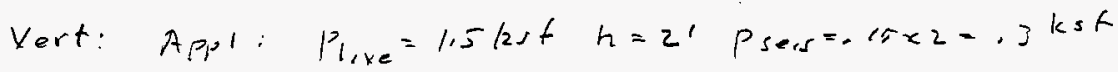

ok

Herzl: Cover blocks \& walls: oils

Lower cull \#8E12"EFEW 213 frombottom

$$
\begin{aligned}
& h=2 \text { ' 2"dr } \quad d=22 " M_{n}=.95 \times 22 \times \frac{.79}{12} \times 40=55 \mathrm{~K} \\
& b=26^{\circ} \quad a=29^{\prime} \quad a / b=29 / 26=1.11 \quad \beta=.333 \\
& H_{\text {max }}=21.0+2+29.5+2.7=55.2^{\prime} \\
& P_{\text {Sew }}=0.8 \times .125 \times 55.2=5.5^{K} \\
& \text { Hake }=21+2+15=38^{\prime} \quad P_{\text {sail }}=.4 \times 1.125 \times 38=1.9 \mathrm{ksf} \\
& m_{\text {ser }}=\frac{p}{6} p b^{2}=\frac{.333}{6} \times 5.5 \times 26^{2}=206 \mathrm{~K} \\
& M_{\text {so.1 }}=\frac{1.9}{5.5} \times 206=71^{k}>55^{k} \\
& \text { N.G. (static) }
\end{aligned}
$$

Refined calculations with edge

1) restraints might show a positive margin; not in scope.

Upper wall to eq ins

$$
\begin{aligned}
& h=2 \text { " 2"ar } d=22 " m_{n}=.95 \times 22 \times \frac{.44}{9} \times 40=41^{k} \\
& b=19^{\prime} \quad a=2 c^{\prime} \quad a / b=26 / 19=1.37-\beta=-43 \\
& A_{\text {max }}=55.2^{\prime} \text { Pse.s }=1.15 \times .125 \times 55.2^{\prime}=7.4^{\mathrm{ks} F} \\
& \text { Have }=19 / 2=9.5^{\prime} \quad \text { PSO.l }=0.4 \times .125 \times 9.5=.48^{\mathrm{kSF}} \\
& M_{\text {sets }}=\frac{\beta}{6} p b^{2}=\frac{.43}{6} 7.4 \times 19^{2}=204^{K} \\
& m_{50.1}=\frac{.48}{7.9} 204=12.4^{K}
\end{aligned}
$$

7 
KAISER ENGINEERS HANFORD

Client

Subject
WHC-SD-WM-TI-775, Rev. 0

DESIGN ANALYSIS
Calc. No. P. 4-27

Revision

Page No. 21 of

WO/Job No. 
KAISER ENGINEERS

WHC-SD-WM-TI-775, Rev. 0

Calc. No. P. 4-28

DESIGN ANALYSIS

Revision

Page No. 22 of

Client

WO/Job No.

Subjecr

Sersmer

Date

Location

Revised

145

$244-5$ Seesmic

Yert: Coverblks: App': Plive $=0.28 \mathrm{kst} h=2^{\prime}$

$$
a_{\text {max }}=\frac{1.35}{2} \cdot \frac{0.28}{0.15 \times 2}=0.63 q
$$

Itrzl: Coverbltes wall

$$
\begin{aligned}
& b=2+\frac{1}{3}(11-2)=5^{\prime} \\
& h_{\text {uxe }}=\left(2 \times 11.5^{\prime \prime}+-3 \times 16^{\prime \prime}\right) / 5 \\
& =14.2^{\prime \prime} \\
& 2 \text { "dr } \quad d=12.2 \text { " "8e 8" } j=.95
\end{aligned}
$$$$
m_{n}=.95 \times 12.2 \times \frac{.79}{8} \times 60=69^{\mathrm{k}}
$$$$
w_{\text {sers }}=.15 \times 2 \times 20=6^{\mathrm{k} / 1}
$$$$
M_{\text {seas }}=\frac{W L^{2}}{86}=\frac{6 \times 20^{2}}{8 \times 5}=60^{k}
$$$$
w_{\text {so: } 1}=2^{\prime} \times 150\left(1+\frac{1}{2}\right)=.46 \mathrm{k}^{\prime \prime}
$$$$
\text { Mso.1 }=\frac{.46}{6} 60=4.6 \mathrm{kl}
$$$$
a_{\max }=\frac{1.35}{1} \frac{69+4.6}{60}=1.6 \mathrm{~g}
$$

Upper well

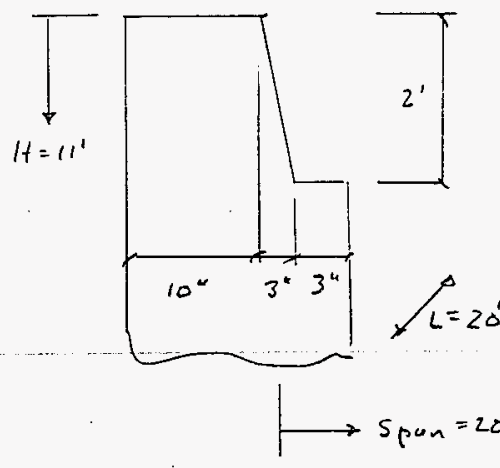

$$
\begin{aligned}
& H_{\text {max }}=\|^{\prime} \text { Psecs }=1.15 \times 14=1.15 \times .125 \times 11=1.58 \mathrm{ksF} \\
& b=9^{\prime} \quad a=20^{\circ} \quad a / b=2.2 \quad \beta=.63
\end{aligned}
$$

Hee12 $\quad d=16-2=14^{\pi} \quad M_{n}=.95 \times 14 \times \frac{.79}{12} \times 60=53^{\mathrm{K}}$

$$
\begin{aligned}
& M_{\text {sees }}=\frac{\beta}{6} p b^{2}=\frac{.63}{6} \times 1.58 \times q^{2}=13.4^{\mathrm{K}} \\
& H_{\text {axe }}=5.5^{1} \quad P_{50.1}=0.4 \times .125 \times 5.5=.28^{\mathrm{ksF}} \\
& M_{\text {so.1 }}=\frac{.28}{1.58} \times 13.4=2.3^{\mathrm{K}}
\end{aligned}
$$

54.4300.037 KEH-0037.00106/92

$1 / 6$ 
KAISER ENGINEERS
HANFORD

WHC-SD-WM-TI-775, Rev. 0

DESIGN ANALYSIS
Call. No. $P,-2$.

Revision

Page No. 23 of

Client WO/JOb No.

Subject seismic

Location

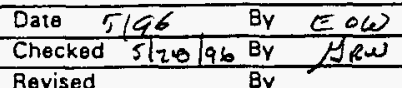

Revised

By

$$
a_{\max }=\frac{1.35}{1} \frac{53-2.3}{13.4}=59
$$

Carson:

$$
\begin{aligned}
& H_{\text {mex }}=606^{\prime}-619^{\prime}=47^{\prime} \gamma_{\text {mWTF }}=0.0332_{0} \\
& w=G 8 / 2=1.3 e 6 \times \frac{.033}{2 \times 100}=215 p 5 i \\
& v_{c}=2 \sqrt{f_{i}}=110 \mathrm{psi} \\
& v_{s}=\frac{A_{w} f_{y}}{s_{2} d} \quad d=0.8 h \quad h=12 " \# 5 e 12 \quad h r z 1 \\
& v_{s}=\frac{.31 \times 60=3}{.8 \times 12 \times 12}=161 \mathrm{ps}: \\
& v_{n}=v_{c}+v_{s}=110+161=271 p_{5}: \\
& a_{\max }=1.35 \times .38 \times \frac{271}{215}=0.64 \mathrm{~g}
\end{aligned}
$$

Note: extra strength expected from corrugated liner grout

117

54-4300-037 KEH-0037.00 106/92

$T$ 


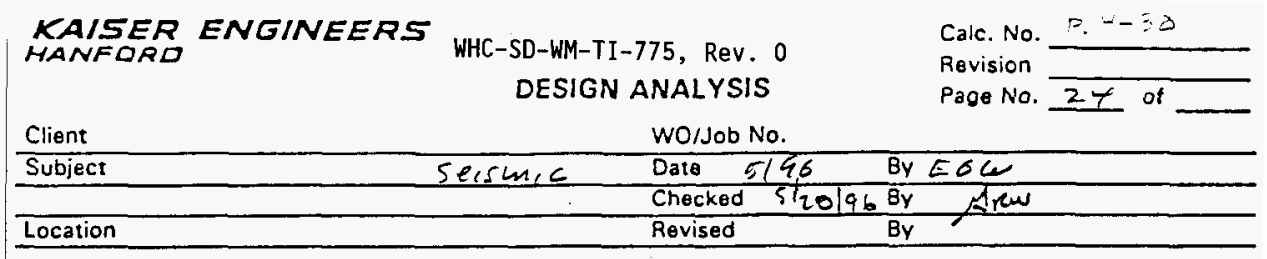

$241-5-304$ Seismic

Vertical: Coverblks: App 1 Clive $=0.736$ st $h=2.5^{\prime}$

$$
a_{\text {max }}=\frac{1.35}{2} \frac{.73}{.15 \times 2.5}=1.39
$$

Horiz: Couerbtes wall

$$
\begin{aligned}
& b=1.7+\frac{1}{3}(7.5-1.7)=3.3^{1} \\
& h_{\text {que }}=\left(7.7 \times 7.5^{11}+1.9 \times 12\right) / 33 \\
& =10.8^{\prime \prime} \\
& c l_{r}=1.5^{\prime \prime} \quad d=9.3^{\prime \prime} \neq 5 e^{12} \\
& M_{n}=.95 \times 9.3 \times \frac{.21}{12} \times 60=13.6^{\mathrm{K}} \\
& w_{\text {sees }}=\gamma \mathrm{hs}=.15 \times 2.5 \times 11.8=4.4 \mathrm{ki} \\
& w_{\text {sol }} \simeq \text { neglect } \\
& M_{\text {leis }}=\frac{\omega L^{2}}{86}=\frac{4.4 \times 11.8^{2}}{8 \times 3.3}=2.3 .2^{K} \\
& a_{\text {max }}=\frac{1.35}{1} \cdot \frac{13.6}{23.2}=0.79 q
\end{aligned}
$$

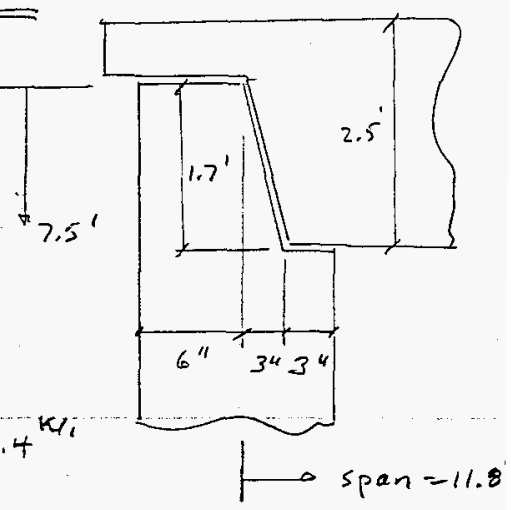

Caisson roof: Pat is not concentres with carson at seismic inerica (herzl) induces roof loads

$$
\begin{aligned}
W & =\left(\begin{array}{c}
5.8 \times 4 \times 1 \times 11.8 \\
+2.5 \times 13^{2}
\end{array}\right) \times 15^{\mathrm{kCF}} \\
& =41^{\mathrm{k}}+63^{\mathrm{k}}=104^{\mathrm{k}} \\
F_{i} & =W W \mathrm{~g} \quad \\
h_{i} & =(41 \times 58 / 2+63 \times(5.8+25 / 2)) / 104 \\
& =5.4^{1}
\end{aligned}
$$

118

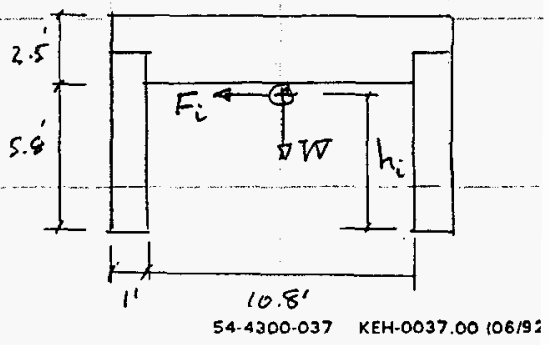




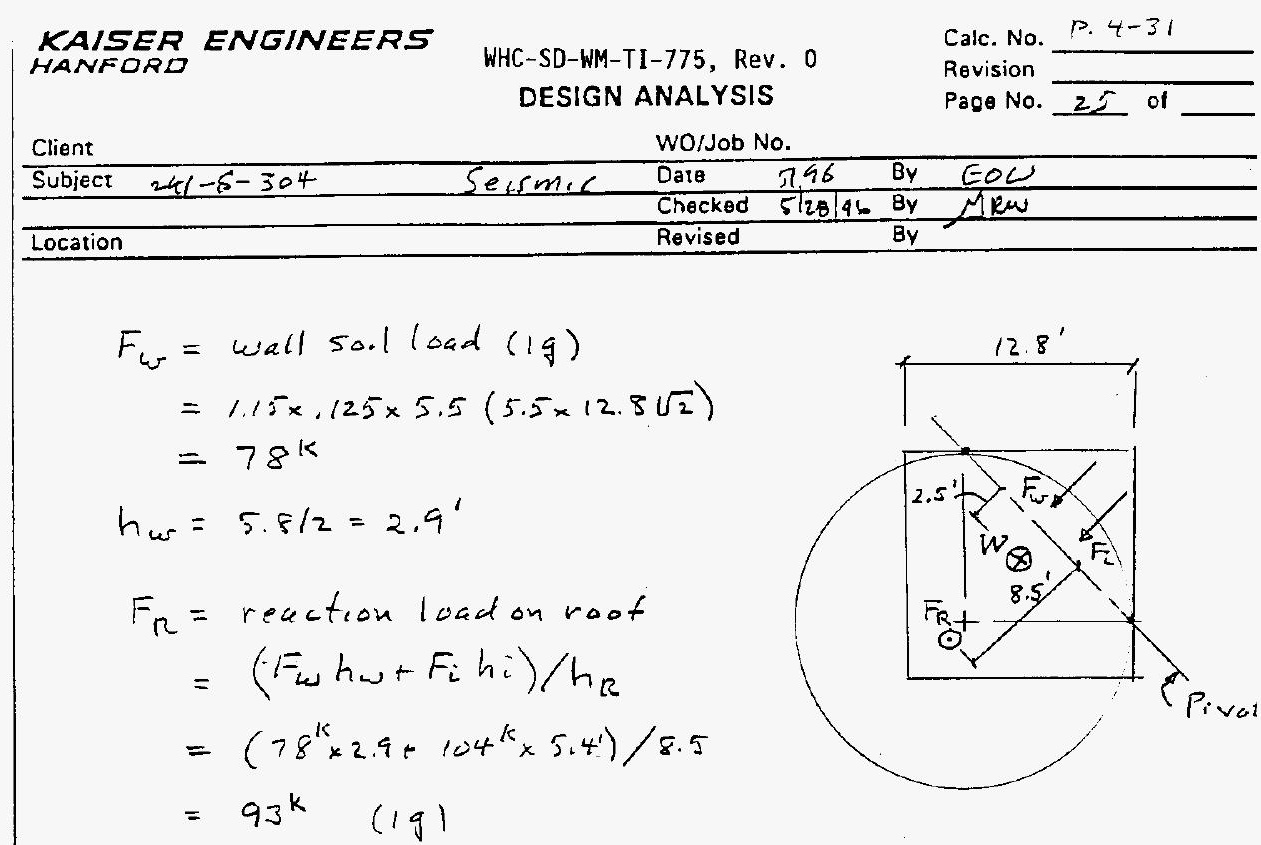

From pet wt: $F_{D \omega}=\frac{2.5^{\prime}}{8.5} \mathrm{~W}=\frac{2.5}{8.5} 104=31^{\mathrm{K}}$

WIs beams support roof wt

$R / c$ root: \#6 eq" $h=15^{\prime \prime} d r=3 / 4 " d=14.25 " i=.95$

$$
M_{n}=.95 \times 14.25 \times \frac{44}{9} \times 60=40 \mathrm{~K}
$$

Est $F_{R}$ distributed over center $20 \%$ square plate

$$
a=b=\sqrt{\frac{\pi}{4}} 2 R=V .285 \times 16=14.2^{\prime}
$$

Rourke th $M=\frac{\beta}{6} F \quad \beta=1.82$ th $20 \% \quad M=0.3 \mathrm{~F}$

$$
\begin{aligned}
& M_{R}=0.3 F_{R}=0.3 \times 93=28 \mathrm{k} \\
& M_{\text {OW }}=0.3 F_{\text {OW }}=0.3 \times 31 \mathrm{k}=9 \mathrm{k} \\
& a_{\text {max }}=\frac{1.35}{2} \cdot \frac{M_{n}-M_{0 w}}{M_{R}}=\frac{1.35}{2} \frac{40-9}{28}=0.75 \mathrm{~g}
\end{aligned}
$$

Reversing soil-wull and pit inertia loads fillolitt roof off caisson wall at $F_{L}$ where dowel are

119

$54.4300-037$ KEH-0037.00106/9 
KAISER ENGINEERS

WHC-SD-WM-TI-775, Rev. 0

Call. No. P. $4-32$

DESIGN ANALYSIS

Revision

Page No. 26 of

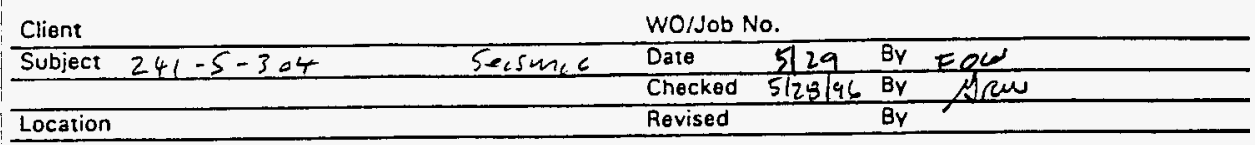

not long enough, Liftoff

$\Rightarrow$ impact, damage $\$ 1055$

of shear capacity for down loads. Est soil over roof lowed

$$
\begin{aligned}
W_{s} & =(\overline{h t} \times \overline{(\mathrm{en}} \times \overline{w d t h}) r_{s} \\
& =\left(55^{\prime} \times 17^{\prime} \times 4^{\prime}\right) r_{s} \\
& =320 \mathrm{ft}^{3} \times .125 \mathrm{kct}=47^{\mathrm{k}}
\end{aligned}
$$

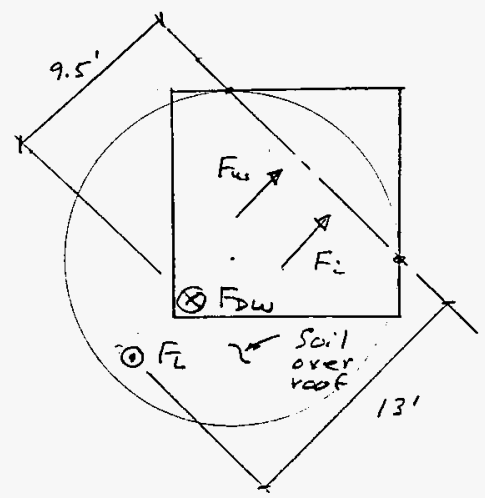

$F_{L}$ (dead $\left.\omega t\right):$

$$
\begin{aligned}
& F_{\text {OW }}=\frac{104^{\mathrm{k}} \times 25^{\prime}+47^{K} \times 9.5^{\prime}}{13^{\prime}}=5.9 \mathrm{k} \\
& F_{L}(\mathrm{gg}): \\
& F_{L}=\frac{78^{k} \times 2.9+104^{k} \times 5.4}{13}=61 \mathrm{k} \\
& a_{\text {max }}=\frac{1.35}{2} \cdot \frac{F_{\text {ow }}}{F_{L}}=\frac{1.35}{2} \cdot \frac{59}{61}=0.60 \mathrm{~g}
\end{aligned}
$$

120

54.4300-037 KEH.0037.00 106/92

1 
KAISER ENGINEERS

WHC-SD-WM-TI-775, Rev. 0

Canc. No. $[\cdot 4-33$

DESIGN ANALYSIS

Revision

Page No. 27 of

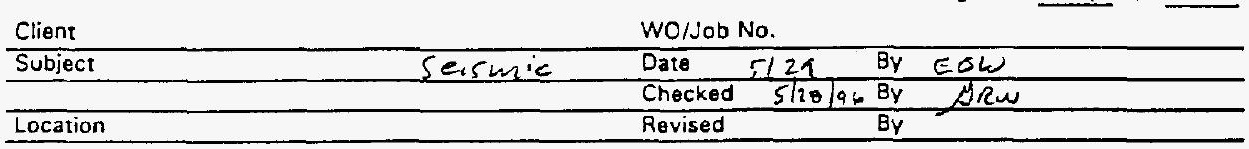

200 Series Seismic

Vertical: Flat rust: see Apps: $M_{n}=26^{\mathrm{K}}$

$$
\begin{aligned}
P_{50.1} & =9.7 \text { ps: } \\
& =1.4 \mathrm{ksf}
\end{aligned}
$$

Est. equiv plate as $8 \times 9^{\prime}, \beta=0.3$

$$
\begin{aligned}
& M=\frac{\beta}{6} p b^{2}=\frac{.3}{6} \times 1.4 \times 8^{2}=4.5^{K} \\
& a_{\text {max }}=\frac{1.35}{2} \times \frac{26}{4.5}=4 \mathrm{~g}
\end{aligned}
$$

Per App 1: Plive $=1.0$ ks f

$$
a_{\max }=\frac{1.35}{2} \times \frac{1.0}{1.4}=0.48 \mathrm{~g} \quad \text { (conservative) }
$$

Herzl:

$$
\begin{aligned}
& H_{\text {max }}=37^{\prime} \gamma_{\text {MWTF }}=.0282_{0} \\
& v=1.3 e 6 \times \frac{.028}{2 \times 100}=180 \mathrm{psi} \\
& v_{c}=2 \sqrt{f_{c}}=110 p s i \\
& \left.v_{1}=172 \text { si (kemble, } p E-21\right) \quad v_{n}=11 \Delta+172=282 p \\
& a_{\max }=\frac{1.35}{1} \times .38 \times \frac{282}{180}=0.807
\end{aligned}
$$

121

54-4300-037 KEH-0037.00 106/9:

T 
WHC-SD-WM-TI-775, Rev. 0

\section{Appendix 5}

\section{Internal Static Vacuum}

DCRTs, catch tanks and 200-series SSTs are structurally evaluated for a vacuum loading of $-8 \mathrm{psig}$ to determine if a an opening could result to the atmosphere.

Most of the structures have steel tanks inside a vault or caisson under a pit capped with cover blocks at the surface. The first check in such cases is an evaluation for buckling of the steel tank. Although the procedure involves a capacity reduction factor of 0.5 which appears to provide a margin between design an minimum test data, it is considered prudent for this level of effort and lack any of tank condition assessments to retain the factor and interpret the result as a minimum strength. Most steel tanks are ok at the $-8 \mathrm{psig} l o a d$. For those that are not and those for which information was not located, the vacuum is extended to the enclosing vault or caisson on the basis of volume ratios, and the vault is then check. All these cases prove satisfactory, except one in which the side wall is marginal. Nevertheless, a significant opening is not expected.

Some steel tanks are buried directly in the soil, and the major loading appears to be soil load. Considerable variation can be found in procedures for assessing soil loads on buried pipe. Simple hydrostatic pressure based on soil density was used for this level of effort, and the vacuum loading was added directly. Some directly buried tanks fail under this combined loading, but the depth to diameter ratio is so large that a significant opening to the atmosphere is not expected.

This load case produces no expected openings to the atmosphere as a result of structural failure. Normal openings to the atmosphere have not been considered. In the case of directly buried tanks that collapse, tearing need not be significant, and a liquid spout caused by bladder pressurization by the soil and tank wall is not precluded. This possibility has not been evaluated. 
WHC-SD-WM-TI-775, Rev. 0

Table 5.1 Internal Vacuum Summary

\begin{tabular}{|c|c|c|c|}
\hline Tank & Structural Item & OK/NG by Item & Overall \\
\hline $241-A-302-A$ & Steel tank & OK & OK \\
\hline $241-A-417$ & Tank roof & OK & OK \\
\hline $241-A X-152$ & Tank roof & OK & OK \\
\hline $241-A Z-151$ & $\begin{array}{l}\text { Tank roof } \\
\text { Tank side wall }\end{array}$ & \begin{tabular}{|l} 
OK \\
Marginal
\end{tabular} & OK, no opening \\
\hline 241-ER-311 & Steel tank & NG & NG, no opening \\
\hline 241-EW-151 & $\begin{array}{l}\text { Steel tank } \\
\text { Vault roof }\end{array}$ & $\begin{array}{l}N G \\
\text { OK }\end{array}$ & OK \\
\hline $241-T X-302-C$ & Steel tank & OK & OK \\
\hline $241-U X-302-A$ & Steel tank & NG & $N G$, no opening \\
\hline $241-U-301-B$ & $R / C$ tank & $\mathrm{OK}$ & OK \\
\hline $241-A-350$ & $\begin{array}{l}\text { Steel tank } \\
\text { Caisson roof }\end{array}$ & $\begin{array}{l}\text { Not evaluated } \\
\text { OK }\end{array}$ & OK \\
\hline $244-B X / T X / U$ & $\begin{array}{l}\text { Steel tank } \\
\text { Vault roof }\end{array}$ & $\begin{array}{l}\text { NG } \\
\text { OK }\end{array}$ & OK \\
\hline $244-C R$ & $\begin{array}{l}\text { Steel tank } \\
\text { Vault roof }\end{array}$ & $\begin{array}{l}\text { Not evaluated } \\
\text { OK }\end{array}$ & OK \\
\hline $244-5$ & $\begin{array}{l}\text { Steel tank } \\
\text { Caisson roof }\end{array}$ & \begin{tabular}{|l} 
NG \\
OK \\
\end{tabular} & OK \\
\hline $241-5-304$ & Steel tank & OK & OK \\
\hline 200 Series & $R / C$ tank & $\mathrm{OK}$ & OK \\
\hline DST / SST & $R / C$ tank & OK & OK \\
\hline
\end{tabular}


KAISER ENGINEERS

WHC-SD-WM-TI-775, Rev. 0 DESIGN ANALYSIS
Call. No. $P .5=$

Revision

Page No. of

Client WO/Job No.

Subject Int Vacusem Date $5 / 13 / 96$ BY Eq CS

Location

Revised

$241-A-302-A$

2.1 Internal vacuum

mat'i 55A A-416-304L

ERS:

$\left(C_{y} l\right)$

$$
\begin{aligned}
& L / t=16.5 / 4.5=3.7 \\
& t / r=9 / 16 / 12 / 4.5=0.01 \\
& \beta=2.6 e-4
\end{aligned}
$$$$
T=\frac{211}{16}
$$$$
p_{c r}=E \frac{t}{r} B=28 e 6 \times .010 \times 2.6 \mathrm{e}-4
$$

$$
\begin{aligned}
& =76 p_{5} i \\
p_{L} & =1 / 2 p_{L V}=38 p_{5 i}
\end{aligned}
$$

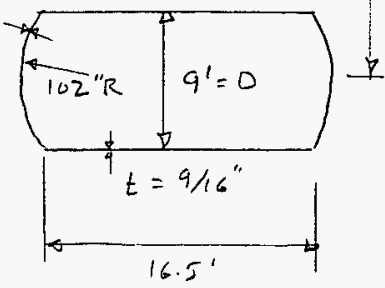

$p=p_{\text {so. }}+p_{\text {wac }}=22 \times 125 / 144+8=27 p_{5}<<p_{\text {s. }}<$ ok

$($ lead):

$$
\begin{aligned}
& p_{u}=0.18 \times 1.21 E(T / R)^{2} \\
& =0.18 \times 1.21 \times 2806\left(\frac{71 / 6}{102}\right)^{2}=112 \mathrm{psi}>27 \mathrm{ps}_{i} \mathrm{ok}
\end{aligned}
$$

Tank does not collapse.

124

$\Rightarrow$ GP. $\quad 689-996 \quad 12 / 9$ 
KAISER ENGINEERS

HANFORD
WHC-SD-WM-TI-775, Rev. 0

DESIGN ANALYSIS
Calc. No. P, 5-4

Revision

Page No. $z$ of

Client Wo/sob No.

Subject

Date $5 / 13196$ By ENter

Location

Revised

By

$241-A-417$

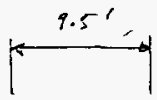

2.1 Internal vacuum -8 prig

Dug H-2-56800

Tent root acts as double tee beam. Est.

worst situation is roof

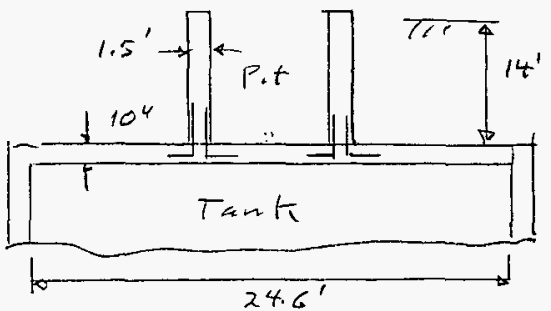

acting as that plate.

$$
\begin{aligned}
L & =\frac{1}{2}(24.6-9.5)=2.5^{\prime} \\
\omega= & \text { Psoilt puss } \\
= & 14^{\prime} \times 125 \text { pct } / 144 \mathrm{in}^{2} / \mathrm{ft}^{2} \\
& +8 \text { psi } \\
= & 20 \text { psi } \\
M_{L}= & \frac{\omega L^{2}}{8}=\frac{20 p 5 i}{8}(-7.5 \times 12)^{2} \\
= & 20000^{k}=20^{\mathrm{K}}
\end{aligned}
$$

Tantroof $h=10^{\prime \prime} \%=\mathrm{m}$

$$
\begin{aligned}
& d=8.5^{\prime \prime} \quad \text { Le. } 6^{4} E E \\
& L=7.5 \\
& P_{s}=.44 / 6 / 8.5=.608 \quad j=.94 \quad \text { Est } f_{y}=40 \mathrm{ksi} \\
& M_{n}=j d A_{s} f_{g}=0.94 \times 8.5^{\prime \prime} \times 0.44 \% 6-40 k s=23^{k}>20^{k}
\end{aligned}
$$

Dowels are "6e9"EF from roof to pit wall

OK

$$
\begin{aligned}
& R=\frac{5}{8} w L=\frac{5}{8} 20 \text { psi } \times 9{ }^{\prime \prime} \times 7.5 \times 12^{\prime \prime}=10000^{k}=10^{k} \\
& A_{s} f_{y}=0.44^{12^{2}} 40^{\mathrm{ksi}}=17.6^{\mathrm{k}}>10^{\mathrm{K}} \text { ok }
\end{aligned}
$$

Roof remains intact.

125

DG.P.O. $\quad 689-996 \quad 12 / 5$

7 
KAISER ENGINEERS

HANFORD

,

Lo

Client

Subject

Location

$241-A x-152,241-A z-151$

2.1 Internal vacuum - sprig

$\frac{241-A x-15 z}{\text { Taint roof }}$

$h=8$ "lined 5.5. * 4 er EW BOT

$$
P_{s}=.2 / 8 / 8=.008
$$$$
j=0.94
$$

$d=8-\frac{3}{4}=7.25^{\prime \prime}$

Est $f_{y}=40 \mathrm{ksi}$

$$
M_{n}=j d A_{s} f_{y}=.94 \times 7.25^{\prime \prime} \times 0.20 \% 8 \times 40^{\mathrm{ksi}}=6.8 \mathrm{~K}
$$

Use $8 / 12 \times 1$ psi $=.7$ psi for floor wt

$$
\begin{aligned}
& p=p_{\text {vac }}+p_{\text {canc }}=8+0.7=8.7 p_{i} \\
& M=\frac{P L 2}{8}=\frac{8.7 P S_{c}}{8}\left(72^{\prime \prime}\right)^{2}=5600^{4}=5.6^{k}<6.8^{k} \underline{\Delta K} \\
& V_{n}=2 V \cdot f^{\prime} d=2 V 3000 \times 7.25=750^{4 / 11} \\
& \check{V}=\frac{P L}{2}=8.7 \times 72 / 2=310^{4 / 11}<750^{4 / 1} \text { oK }
\end{aligned}
$$

Side wall: $h=18^{\prime \prime} d=18-3 / 4=17.25 \quad$ "te $10^{\prime \prime}$ vert ins de

$$
\begin{aligned}
& \bar{j}=0.95 \quad f_{y}=40 \mathrm{ks} \\
& M_{n}=j d A_{s} f_{y}=0.92 \times 17.21 \times 0.44 / 8 \times 40 \mathrm{ksi}=37^{\mathrm{K}}
\end{aligned}
$$

Soil load : $K_{0}=0.4 \quad \gamma=125$ p of $\quad 16=21.5$

$$
\begin{aligned}
& \mathrm{L}_{\text {sol }}=\mathrm{K}_{\Delta \gamma H}=0.4 \times 125 \mathrm{pcF} \times 21.5=1080 \mathrm{psf} \\
& =7.5 \mathrm{ps}^{\circ} \\
& p_{t \circ t}=p_{s 01}+p_{x a c}=7.5+8=15.5 \text { psi }
\end{aligned}
$$




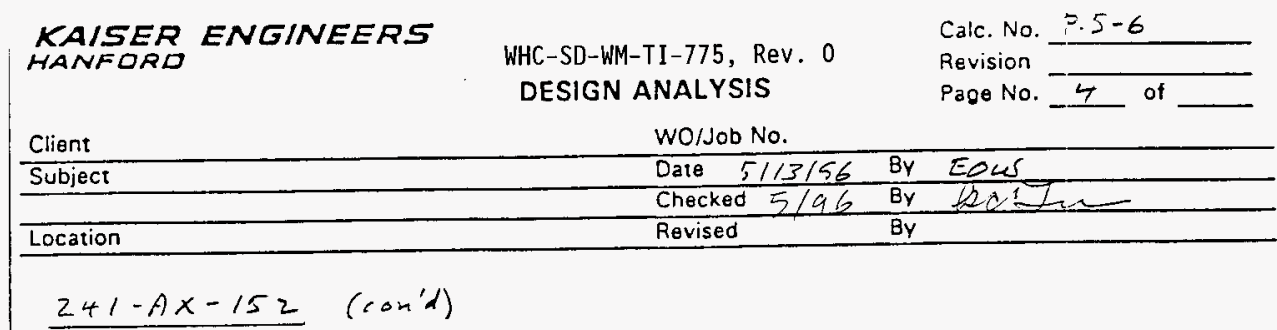

2. $\log (\cos )$

$$
M=\frac{w L^{2}}{8}=15.5 \times\left(115 \times 12^{\prime \prime}\right) / 8=37^{k} \leq 37^{k} \quad \underline{0 k}
$$

Expect less load a more strength:

- Partial fixity at edges

- Soil load degrease with wall movement

$241-A z-151$

Similar to 241-Ax-152. Same conclusion tor vault roof (ok). Vault side walls do not pass since

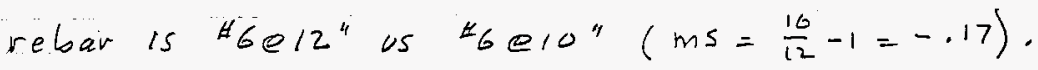
Cakes are conservative (see above), and bending failure in side wall is not expected to give significant opening to atmosphere.

127

AG.P.O. $\quad 689-996 \quad 121$ 
KAISER ENGINEERS HANFORD
WHC-SD-WM-TI-775, Rev. 0

DESIGN ANALYSIS
Call. No. ? $5-7$

Revision

Page No. 5 of
Client

Subject

WO/Job No.

Date $5 / 10196$ By EO LW

Checked $5 / 9 / 2$ By Dr o

Location

Revised

By

$241-E R-311$

int. Internal vacuum - 8 prig

SAR-067

$$
t=9 / 16^{\prime \prime} \quad H=20^{\prime} \quad D=9.5^{\prime} \quad L=40^{\circ}
$$

ERSC for capacity:

$$
\begin{aligned}
& L / r=40 / 5.5 \times 2=8.4 \\
& t / r=9 / 16 / 12 / 9.5 \times 2=0.01 \\
& \beta=1 e-4
\end{aligned}
$$

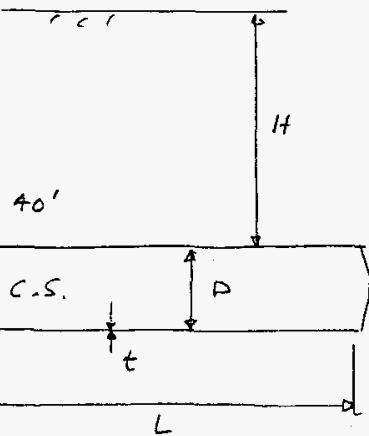

Demand: $p_{50.1}=\gamma(H+r)=125 p<f \times 25^{\circ} / 144 \mathrm{in} 2 / f+2$

$$
\begin{aligned}
& =22 \text { psi } \\
p_{\text {vac }} & =8 \text { ps: } \\
p_{\text {tot }} & =p_{\text {sol }}+p_{v a c}=22 t 8=30 \text { psi }
\end{aligned}
$$

$>14$ psi No good

Tanto could collapse, tearing expected, no - significant opening to atmosphere with it $/ 0=2$

128

$\Rightarrow$ G.F.O. $\quad 689-996 \quad 12 / 5$ 


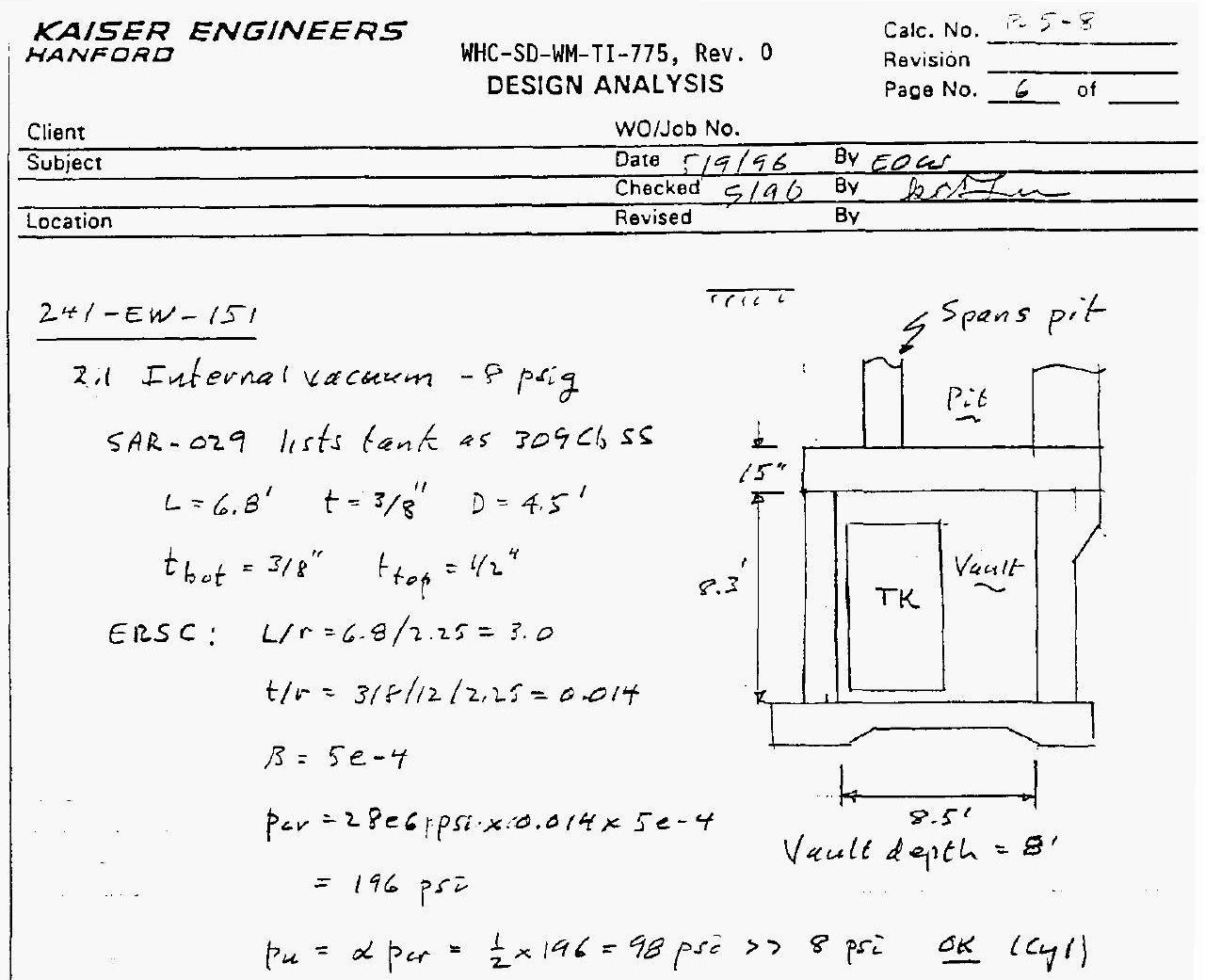

Heads: ure ASME Seat XIIT AD -700

Req'd head tht: $T=d \sqrt{\frac{C P}{k S}}$

$$
d=0=54^{\prime \prime} \quad p=8 \text { ps: }
$$

Use $k=i .2$ wath $S$, est badec $5 s . s=20 \mathrm{ksi}$

$$
\begin{aligned}
& k S=1.2 \times 20=24 k 5: \\
& C=0.44 \text { (maxin Fig AD.701.2) } \\
& T=54^{\prime \prime} \sqrt{\frac{0.44 \times 8}{24 e^{3}}}=0.65>t_{\text {top }} \text { or thot N.G. }
\end{aligned}
$$

$\therefore$ heads may collepte.

129

מG.P.O. $689-996 \quad 121$ 
KAISER ENGINEERS

HANFORD
WHC-SD-WM-TI-775, Rev. 0

DESIGN ANALYSIS
Talc. No. P. 5-9

Revision

Page No. 7 of

Client Wo/Job No.

Subject

Date $\$ 196$

Location

Revised

Eon

$2+1-E \omega-151\left(\operatorname{con}^{\prime} d\right)$

Expansion:

$$
\begin{aligned}
& V_{t t}=\frac{\pi}{4} \times 4.5^{2} \times 6.5=110 \mathrm{ft}^{2} \\
& V_{\text {Vault }}=8.3 \times 8.5 \times 8=560 \mathrm{ft} \\
& P_{\text {vault }}=P_{t t} \frac{V_{t t}}{V_{\text {vat }} 1 t}=8 \mathrm{psi} \frac{110}{560}=1.6 \mathrm{p5}
\end{aligned}
$$

Vault roof: $h=18^{\prime \prime} 1,5^{\prime}$ clear $78 Q 9^{\prime \prime}$ for $L=8.5^{\prime}$

Use: lis psi for concrete wt

$$
P_{\text {tot }}=P_{\text {vault }}+P_{\text {condor }}=1.6+115=3 \text { pro }
$$

$m_{n}: \ldots j=0.95 \quad d=16.5^{\prime \prime}$ use $f_{y}=40$ teas:

$$
\begin{aligned}
& m_{n}=j d A_{s} f_{y}=0.45 \times 16.5^{\prime \prime}+0.79 / 9 \times 40^{\mathrm{ksi}}=55^{\mathrm{K}} \\
& m=\frac{\omega L^{2}}{\xi}=3 p \operatorname{si} \times(8.5 \times 12)^{2} / 8=3900^{*}=4^{k}<52^{k}
\end{aligned}
$$

Ok

Vault ceiling holds easily agana vacuum.

130

S.G.P.O. $\quad 689-996 \quad 121$

T 
KAISER ENGINEERS

HANFORD
WHC-SD-WM-TI-775, Rev. 0

DESIGN ANALYSIS
Call. No. P.5-12

Revision

Page No. 8 of

Client Wo/Job No.

Subject Date $5 / 9 / 96$ By EOCS

Location

Checked 5196

hor

$21241-T x-302 C$

$241-4 x-302 A$ Internal vacuum - Prig

ERST:

$$
t / r=9 / 16 / 4.5 / 12=.010
$$

Data: SAR-OC?

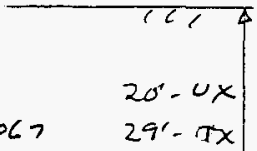

$L / V=36 / 4, S=8$

$\beta=1.1 e-4$

$9 / 16 "$

$$
P_{c r}=28 e 6 \times .010 \times 1.12-4=31 p_{8 i}
$$

$P_{\text {tat }}=x H+P_{\text {wat }}$

$=125 \times 29 / 144+8$

$=33$ psi $(T x)>31$ psi N.G.

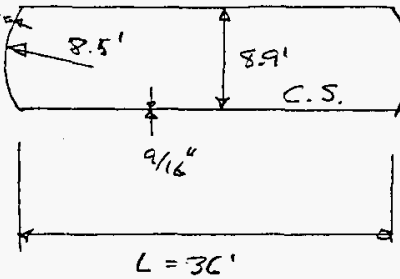

$(1 t-2-832)$

$=125 \times 20 / 144+8=25 p 5 i(U x)<31$ psi $0 k$

cheat head:

$$
\begin{aligned}
& p_{c r}=1.21 E(T / R)^{2}=1.21 \times 28 \mathrm{egsi}(.56 \mathrm{~J} / 90)^{2}=1330 \mathrm{psc} \\
& \eta=0.18 \quad p_{\mu}=0.18<1330 \quad p 5==240 p^{5} 5_{i} \gg 31 p^{\circ} \text { ok }
\end{aligned}
$$

UX does not collapore $\left(t=20^{\prime}\right)$

$T \times$ may collapse $\left(H=29^{\prime}\right)$. Soil would probably care in but no significant openchy expected with $11=29^{\prime}$ us $O=9^{\prime}$. Whale spout Hururiser is not addressed, but note that tearing meg ht not take place as a result of collapse.

131

G.P.O. $689-996 \quad 12 / 4$

1 
KAISER ENGINEERS

HANFORD

WHC-SD-WM-TI-775, Rev. 0 DESIGN ANALYSIS
Call. No.

Revision

Page No. $-\frac{9}{9}$ of

WO/Job No.

Subject

Date $5 / 9 / 96$ By ED er

Location Revised 5106

$241-v-301-B$

2.1 Internal vacuum - 8 ps:

Ave. sol cover pressure on dome

$$
\begin{aligned}
P_{\text {sol }} & =\left(6+\frac{2.5}{2}\right) 125 / 144 \\
& =6.3 p_{5 i} \\
p_{\text {tot }} & =p_{\text {so. }}+p_{\text {vac }}=6.3+8=14.3 p_{5 i}
\end{aligned}
$$

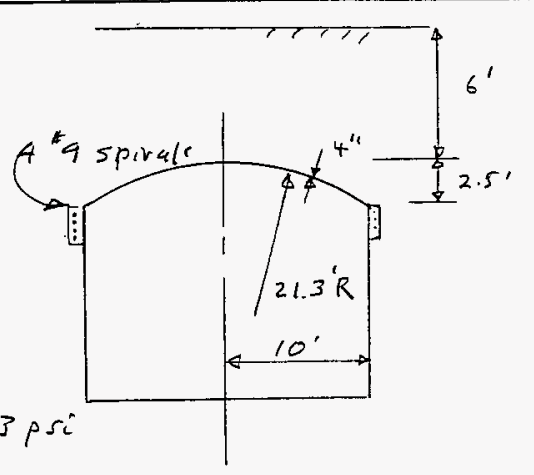

Check dome membrane

$$
\frac{p R}{2 T}=\frac{14.3 \text { psi } \times 21.3}{2 \times 0.333}=460 \text { psi }<900 \text { psi wart. } \sigma \text {. }
$$

Check dome buckling (Zarghame fill eger, ACI Title No 80-45)

$$
\begin{aligned}
\beta_{c} & =0.5 \beta_{\text {in }}=0.5 \quad \varphi=0.7 \\
p_{c r} & =4 \beta_{c} \beta_{m} 0.66 E(t / R)^{2} \\
& =0.7 \times .5 \times .5 \times .66 \times 3 e 6 p_{\text {si }}(.333 / 21.5)^{2}=85 \text { psi } \\
& >15 \text { psi ok }
\end{aligned}
$$

Check capacity of tension ring via $A=105$ test (ARH-R-4)).

Pressure $t$ sties = cont under linear dim scaling A- los l/10 model $(r=45 \%)$ gave $25 x-6$ sol load as capacity. $241-A$ has $9+9+7+6+5+3 \times 4=48$ "/l hoop boars in haunch with $r=40^{\prime}, \ldots A_{s}=48 \times 1.56=75 \mathrm{in}^{2} .1 / 4$ scale $\Rightarrow$

$$
\begin{aligned}
& A_{s}=75 / 16=4.7 \mathrm{in}^{2} \text {. Hake } 4 \text { ta }=4 \times 1.00=4 \mathrm{in}^{2}=A_{\text {st }} \\
& \text { cap }=5 \times 6.3 \mathrm{psi} \frac{A_{S t k}}{A_{S A}}=5 \times 6.3 \times \frac{4}{4.7}=27 \mathrm{psi}>15 \mathrm{psi} \underline{\Delta K}
\end{aligned}
$$

132

S.P.O. $689-996 \quad 12 / 5$ 
KAISER ENGINEERS

HANFORD
WHC-SD-WM-TI-775, Rev. 0

DESIGN ANALYSIS
Cate. No. $>5-12$

Revision

Page No. 10 of
Client

Subject

Location

$241-A-350 \quad(D C R T)$

2.1 Internal vaculem - p prig

Details for tank were not found.

Assume tent collapsed. Scale from H-2-70538; related diss

Tank: $V_{t E}=\frac{\pi}{4} 4.5^{2} \times c=95 \mathrm{ft}^{3}$

Carson: $V_{\text {cases }}=\frac{\pi}{4} \times 8^{2} \times 21=1060 \mathrm{ft}^{3}$

$P_{\text {cars }}=P_{\text {th }} V_{\text {th }} / V_{\text {cars }}$

$=8 \times 95 / 1060=0.7 p 5 i$

Caisson root: $h=12$ " $d=12-3=9 "$

45 el 2 EU $j=.95$

$\therefore \quad f_{y}=40 \mathrm{ksi}$

$M_{n}=j d A_{s} F_{y}=.95 \times 9^{\prime \prime} \times .31 \% / 12 \times 40^{k 6 i}$

$=8.8^{\mathrm{K}}$

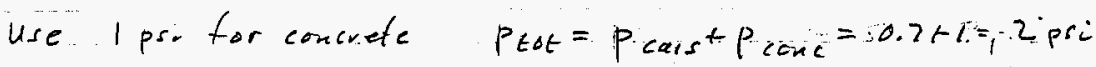

$$
M=\frac{p}{5} \cdot r^{2}=\frac{2 p^{5}}{5} \times\left(48^{\prime \prime}\right)^{2}=920^{k}=0.9^{K}<8.8^{K}
$$

Roof holds.

2.5 Gasoline burn, tho prig

Same. $4544-5$
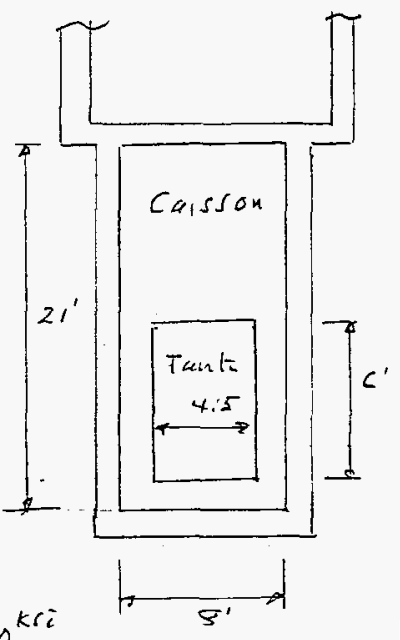
KAISER ENGINEERS

HANFOAD

(

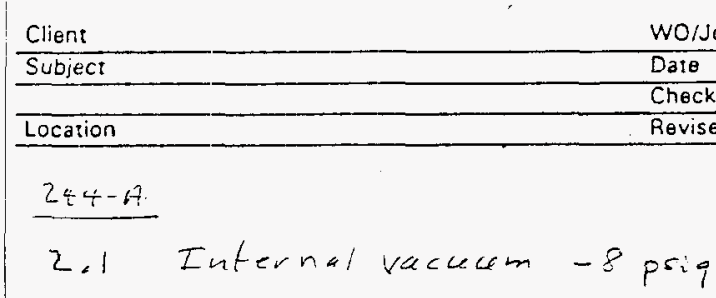

Ca'c. No.

Revision

Pave No.
WHC-SD-WM-TI-775, Rev. 0

DESIGN ANALYSIS

of

cri file not gusilable, Astump tamt collaples.

$$
\begin{aligned}
& V_{\text {tanit }}=\frac{\pi}{4} \times 14^{2} \times 16.5=2500 \mathrm{ff} \\
& V_{\text {cais }}=\frac{\pi}{4} 17^{2} \times 22.5=5100 \mathrm{fts} \\
& P_{\text {cais }}=P_{\text {tant }} \frac{V_{\text {tant }}}{V_{\text {cass }}}=8 \times \frac{2500}{5100}=4 p \mathrm{si}^{\circ}
\end{aligned}
$$

Cusson root: Hoop the elz $j=.95 \mathrm{~h}=12$ " clo $=314$ "

$$
d=11.25 \% \quad 117_{n}=.95 \times 11.25 \times \frac{.31}{12} \times 40=11 \mathrm{k}
$$

ws beams support conerete a equipment

$$
M=\frac{1}{5} p r^{2}=\frac{4 p^{5 i}}{5}\left(8.5 \times 12^{11}\right)^{2}=8^{k}<11^{k} \Delta
$$

2.5 Gasoline burn at 1 to pri - vacuam of -8psi user most of capacity, $\therefore 140$ pri with DLF $>1$ olviousty fails.

134

$\Rightarrow$ G.P. $\quad 689.996 \quad 12194$

T 
KAISER ENGINEERS

HANFORD
WHC-SD-WM-TI-775, Rev. 0

DESIGN ANALYSIS
Call. No. $P .5-4$

Revision

Page No. -12 of

Client

WO/Job No.

Subject

Date $519 / 46$ By Eq

Location

Revised

By

$244-B x / T X / O$ (PERT)

2.1 Internal vacuum - sprig

Tank (SAR) $D=12^{\prime} \quad L=35^{\prime} \quad t=\frac{1^{\prime \prime}}{4}$ CSS.

ERGS: $L / v=35 / 6=5.8 \quad \mathrm{t} / \mathrm{r}=.25 / 6 / 12$

$=0.0035$

$$
\begin{aligned}
\beta=3.3 e-5 & \\
P_{L r}=E \frac{t}{r} \beta & =28 e 6 \times, 0035 \times 3.3 e-5 \\
& =3.2 p r i \\
P_{u}=\frac{1}{2} P_{L r} & =\frac{1}{2} \times 3.2=1.6 \text { psi }
\end{aligned}
$$

Tout collapses

Heads are $3^{\prime}$ deep (SAR)

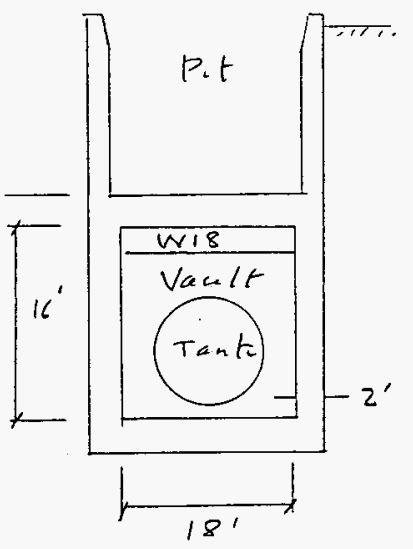

$$
\begin{aligned}
& V_{t t}=\frac{\overline{4}}{4} 12^{2} \times(35+3)=4300 \mathrm{Ht}^{3} \quad \text { Length }=48^{\prime} \\
& V_{\text {Van lt }}=16 \times 8 \times(t 8-2 \times 2)=12700 \mathrm{ft}^{3} \\
& P_{\text {Vault }}=P_{t t} \frac{V_{t \mathrm{r}}}{V_{\text {vault }}}=8 \text { psi } \times 4300 / 12700=2.7 \mathrm{ps}:
\end{aligned}
$$

Vanitiroof:

W18 \& W14 assumed to hold concrete 1 pit equip

$$
\begin{aligned}
& h=2 ! d r=1.5 " \text { 3" ld } d=24-3-1.5=19.5 " \text { " } 11 \mathrm{e} 6 " \\
& f_{y}=60 \mathrm{ks} \quad p=1.56 / 6119.5=0.013 \quad j=0.90 \\
& m_{n}=j d A_{s} f_{y}=0.90 \times 19.5 \times 1.56 / 6 \times 60^{k s_{i}^{\prime}}=270^{\mathrm{k}} \\
& m=\omega \frac{L^{2}}{8}=\frac{8 p 5}{8}\left(18 \times 12^{\prime \prime}\right)^{2}=47000^{*}=47^{k}<270^{k} \text { ok }
\end{aligned}
$$

vault holds under vacuum loading

135

A G.P.O. $689.996 \quad 12 / 9$ 
KAISER ENGINEERS
HANFORD

WHC-SD-WM-TI-775, Rev. 0

Call. No. $\frac{1}{13}-15$

DESIGN ANALYSIS

Revision

of

Client

WO/Job No.

Subject

Date $519 / 96$ By EOA

Location

Revised

BY

$2+4-B x / T x / 4(\operatorname{con} d)$

2.5 Gasoline burn at 140 psi

cheek construction joint at top of vault wall.

Bars are $1106 E$

$$
\begin{aligned}
& \text { Barcap/in }=2 \times 1.56 / 6^{\prime \prime} \times 60^{\mathrm{ksi}}=31^{\mathrm{k} / \mathrm{\prime \prime}} \\
& \text { Pressure load }=\underset{\text { psi }}{p A / C^{\prime}, \quad} \quad, \quad \text { = perimeter } \\
& =1.2 \times .140^{k s i} \times 4.4 x^{\prime} 18^{\prime} /\left(2 \times\left(44^{\prime}+f^{\prime}\right)\right) \times 12^{\prime \prime \prime} \\
& =13^{k / 11}<31^{k / 1} .0 k
\end{aligned}
$$

Check shear around $19 x^{\prime} 8^{\prime}$ pet floor

$$
\begin{aligned}
& V=\frac{P A}{c}=\frac{140^{p+i} \times 1.2 \times 19 \times 18^{\prime}}{2\left(19^{\prime}+18^{\prime}\right)} \times \frac{12^{\prime \prime}}{H t}=19000^{\# / \prime \prime} \\
& V_{n}=2 \sqrt{7_{i}^{\prime}} d=2 \sqrt{4000^{\prime}} \times 19.5^{\prime \prime}=2500^{\# / 1 \prime}<19000^{\# / \prime \prime}
\end{aligned}
$$

NEG.

ar vault roof' is expected to blow out, cover blocks are lifted out, open to atmosphere

136

$\Rightarrow$ G.P.O. $\quad 689-996 \quad 12 / 9$ 
KAISER ENGINEERS

HANFORD

Client

Subject

Location
WHC-SD-WM-TI-775, Rev. 0

DESIGN ANALYSIS
Call. No. $P, 5-16$

Revision

Page No. TY of

of

$24+C R \quad(D C R T)$

WO/Job No.

2.1 Internal vacuum - 8 pig

Pit walls act as tee beam (massive.

Vault ceiling is $2^{\prime}$ the, massive, reinforced. Check side walls:

Aye depth:

$$
\begin{aligned}
& H=20.3+2+29.5 / 2=37^{\prime} \\
& p_{s_{01}}=K_{0} \sigma H=0.4 \times 125 p c t \times 37^{\prime} \\
& \times 1 / 144^{22} \\
& =12.8 \text { psi } \\
& \frac{P_{\text {so. }}+P_{\text {key }}}{P_{\text {s. }}}=\frac{12.8+8}{12.8}=1.63
\end{aligned}
$$$$
\text { Date 5/9/46 BY EOW }
$$$$
\text { Checked } 5 / 46 \text { By odis }
$$$$
\longrightarrow 8^{\prime}
$$

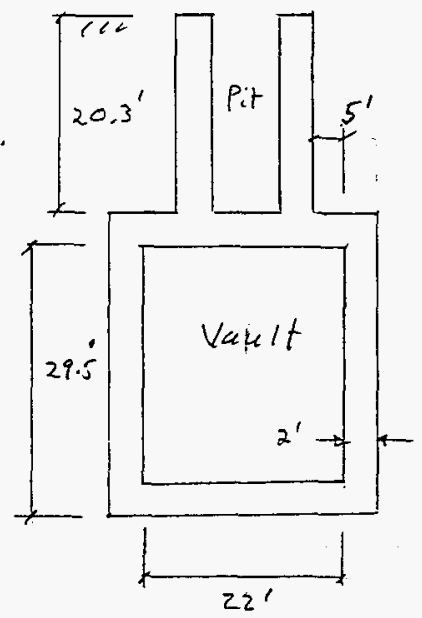

50. Pac is in normal side soil safety factor of 1.7 , ok Vault does not collapse (see gasoline barn calls below)

2.5 Gasoline vapor burn of 140 pro

Check $8^{\prime}$ span (pit floor): $h=2^{\prime} d=22^{\prime \prime}$ " "ae"

$$
M_{n}=0.95 \times 22^{k} \times 1^{\prime \prime 2} / 6 " x+0^{k s i}=139^{k}
$$

Use DLF $=1,2$

$$
\begin{aligned}
& D L F=1.2 \\
& M=\frac{\omega L^{2}}{8}=\frac{1.2 \times 140}{8}\left(96^{\prime \prime}\right)^{2}=190000=190^{k}>139^{k} N_{0} .
\end{aligned}
$$

137

A G.P.O. $\quad 689-995 \quad 121$

7 
$\underset{\text { KAISER ENGINEERS }}{\text { HANFORD }}$

WHC-SD-WM-TI-775, Rev. 0

DESIGN ANALYSIS
Talc. No. P $5-17$

Revision

Page No. If of
Client

Subject

Location

$244-C R$
WO/Job No.

Date $5 / 5196$ BY EQ W

Cheat shear

$$
\begin{aligned}
& V=\frac{w L}{2}=\frac{112 \times 140 \text { psi }}{2} \times 96=8000^{\# / \prime \prime} \\
& V_{n}=2 \sqrt{f_{\alpha^{\prime}}} d=2 \sqrt{3000} \text { psi } \times 22^{\prime \prime}=2400^{4 / \prime}<8000^{\text {\# MIG. }}
\end{aligned}
$$

$\therefore$ Vault does not hold; pit cover blocks blow off, open to atmosphere.

2.1 Note: Into on tanks in vault not found. Collapse under vacuum assumed vault sees full vacuum,

138

$\neq$ GPO.

$689-996$

$12 / 9$ 
KAISER ENGINEERS HANFORD
WHC-SD-WM-TI-775, Rev. 0

DESIGN ANALYSIS
Calk. No. P. $5-15$

Revision

Page No. 16 of
Client

Subject

WO/Job No.

Date $7 / 5 / 46$ By Eon

Checked

Location

Revised

By

$244-S(D C R T)$

2.1 Internal vacuum -8 psi

Taut in caissons flat bottomed $t=1 / 2^{\prime \prime}$. Will collapse Volumes

Taut: $L=17^{\prime} D=15^{\circ}$

$H 271049$

$$
V_{t t}=\frac{\pi}{4} 17^{2} \times 15=3300 \mathrm{ft}^{3}
$$

Carson: $L=21^{\circ} D=20^{\circ}$

14 271043

$$
\begin{gathered}
Y_{\text {cars }}=\frac{\pi}{4} 20^{2} \times 21=6600 \mathrm{ft}^{3} \\
\text { p cars }^{2} p_{t t} V_{\text {th }} / V_{\text {cars }}=8 \times 3500 / 6600=4 \text { psi }
\end{gathered}
$$

Carson roof: $h=12^{*}$ ind $3^{\prime \prime}$ metal d te, $3 / 4$ " $d r$

$$
\begin{gathered}
d=12-3-.25=8.75^{\prime \prime} \\
f_{y}=60 \mathrm{ksi} \quad 55012 \text { EU } \\
m_{n}=j d A_{s} f_{y}=.95 \times 8.75 \% .31 / 16 \times 60^{\mathrm{kit}}=12.9^{\mathrm{K}}
\end{gathered}
$$

4. Wiz .22 beams under roof are taken to support root equipment.

$$
\begin{aligned}
M= & \frac{P_{\text {cats }}}{5} r^{2}=\frac{4 p s i}{5}\left(120^{4}\right)^{2}=11500^{k}=11.5^{k} \\
& <-12.9 k \quad 0 k
\end{aligned}
$$

2.5 Gasoline horn, 140 pig

Carson roof capacity clearly exceed

Pressure on cover blocks = many timer dead weight

Tank tearing expected, contents fully open to athos.

139

AC.P.O. $\quad 689-996 \quad 12 / 9$ 
KAISER ENGINEERS

HANFORD 
KAISER ENGINEERS

Cake. No. P. $5-20$

HANFORD

WHC-SD-WM-TI-775, Rev. 0

DESIGN ANALYSIS
Revision

Page No. 18 of

Client

WOIJob No.

Subject

Dato $5 / 8 / 96$ By Low

Checked $5 / 46$ By h

Location

Revised

BY

200 Series Tank (rr, $\Delta 00$ gal)

2.1 Internal vacuum - 8 prig

(Ramble) pp Elo-ll analyzes

top structure as tee beam and shows a large margin against soil loading.

weakest section is flat plate section ABC which has to be

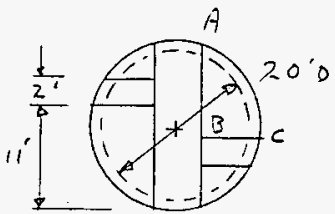

checked for bending a dowel support.

Bending: Use $8^{\prime} \times$ large plate for ABC:

$$
\begin{aligned}
& M=\frac{-L^{2}}{8} \\
& p E-10 \text { (Ramble) } p_{50.1}=1265 \text { psf } \\
& p_{\text {crick }}=150 \text { psf } \\
& \text { Pstic } 1415 \text { pst }=9.7 \text { psi } \\
& P_{\text {tot }}=P_{\text {fecit }} P_{5+c}=1: 8+9.7=0.7 \text { ps } \\
& M=\frac{\left(7.7 \times(8 \times 12)^{2}\right.}{8}=20^{\mathrm{K}}
\end{aligned}
$$

(Ramble)pe-ll shows $\& 8$ e $12 "$ FEW. $h=12^{\prime \prime} \quad c 1 r=1 \frac{1}{2} " d=10.5$

$$
\begin{aligned}
& \rho=.78 / 12 / 10.5=.006 \quad j=.95 \quad f_{y}=40 \mathrm{kri} \\
& m_{n}=j d A_{s} f_{y}=0.95 \times 10.5^{\prime \prime} \times 0.79 / 12 \times 40^{\mathrm{ksi}}=26^{k}>20^{\mathrm{k}} \mathrm{okg}
\end{aligned}
$$

Dowels: (12umble) pe-10,4l sags there are 18 rig" $\phi$ bars supporting each segment such as $A B C$. Dowel capacity:

$$
P_{n}=18 \times A_{s} f_{y}=18 \times \cdot 31 \times 40 \mathrm{kri}=220^{\mathrm{k}}
$$

141

GP. $\quad 689.996$

$12 / 5$ 
KAISER ENGINEERS

HANFORD

Client

Subject

Location
WHC-SD-WM-TI-775, Rev. 0

DESIGN ANALYSIS
Calc. No. P. $5-21$

Revision

Page No. 19 of WO/Job No.

200 Series Tantes (con'd)

Segment area: $\quad A=\frac{2}{3} \times 11 \times 7.5=55 \mathrm{At}^{2}$

$$
P=\frac{5}{8} W=\frac{5}{8} p_{t o t} H=\frac{5}{8} 17.7 \mathrm{pri} \times 55 \mathrm{ft}^{2} \times 144^{\mathrm{kz}} / \mathrm{ft}^{\prime}=88^{\mathrm{K}}<220^{\mathrm{K}}
$$

016

Checte sede wall:

$$
\begin{aligned}
& p_{\text {soor }}=K_{0} \rho 1+\quad K_{0}=0.4 \rho=125 p c t \quad H=12^{\prime}+\frac{25}{2}=25^{\prime} \\
& R=10^{\prime} \quad t=12 \text { " (Ramble p E E } 10-11 \text { ) } \\
& P_{\text {soil }}=0.4 \times 125^{p c t} 25^{\prime} / 144^{i m} / f^{2}=8.7 p^{\circ} \\
& P_{\text {tot }}=P_{\text {vac }}+P_{\text {s. }}=8+8.7=16.7 \text { psi } \\
& \sigma=p R / t=16.7 p s_{i} \times 10 / 1=167 p 5 i \therefore f . \\
& f_{c}^{\prime}=3000 \text { luse } \sigma_{n}=0.55 f_{c}^{\prime}=0.85 \times 3000=2500 \mathrm{pr}: \\
& \rightarrow \sigma_{1} \quad \Delta K \\
& \text { ERSC hueting: } \quad t / R=1 / 10=0.1 \quad L / R=25 / 10=2.5 \\
& \beta=0.0125 \\
& p_{C v}=E t / r \beta=3 e 6 p s: \times 0.1 \times 0.012=3750 p s= \\
& p_{7}=p_{\text {et }} \frac{\sigma_{n}}{\sigma}=16.7 \frac{2600}{167}=26 \Delta \mathrm{pS}^{2}<p_{4}
\end{aligned}
$$

Py goverze, OK

Checte bottom: Relour not determmed. Boftom is 7 "thete, could earilg be overlcad by - 8 prig at bittom (n. contents)

Summan: Top a sider hald, but boltom stuengts not known t could fail, but nof expectod to vesult in an openeng lo at. 142

1 
KAISER ENGINEERS

HANFORD
WHC-SD-WM-TI-775, Rev. 0

DESIGN ANALYSIS
Call. No. P. 5-22

Revision

Page No. 20 of

Client

WO/Job No.

Subject

Date $5 / 5 / 96$ By EDGer

Location

Checked $5 / 96$ By lactira

Revised

By

2.4 DST/55T Internal vacuum - 5 prig

Per 2.5 gasoline burn in ort annulus, primary tank side well, torus forme collapse is expected at $1-2$ psi.

only studs can hold dome up.

cheat studs: $1 / 2 " A 307$ e $24 "$ EU $f_{u}=60 \mathrm{ks}$ : J-lsolt

- Use. (Criteria, Tables 4.1.4-1,2)

$$
F_{y}=\frac{1}{2} A_{s} f_{u} \quad F_{u}=\frac{2}{3} A_{s} f_{4}
$$

Abnormal $F_{a}=\min \left\{0.9 F_{y}, 0.5 F_{k}\right\}$

$$
\begin{aligned}
& =\frac{1}{3} A_{s} f_{u}=\frac{1}{3} \times .785 \times \cdot 5^{2} \times 60^{\mathrm{ks}}, \\
& =3.9^{\mathrm{K}}
\end{aligned}
$$

$$
P_{a}=F_{a} / A=3.9^{k} / 24^{2}=6.8 p s i<8 p 5 i \text { NEG. }
$$

studs are expected to give out.

Cheat re dome: current analysis effort (Peterson) 1..

shows 409 . of shear capace/7 used near haunch with 1.4 load factor F 6 soil at crown $t$ $(.15 \%)$ concrete ${ }_{1}$ load. Estimate equivalent pressure with $6+10 \% 35061:$

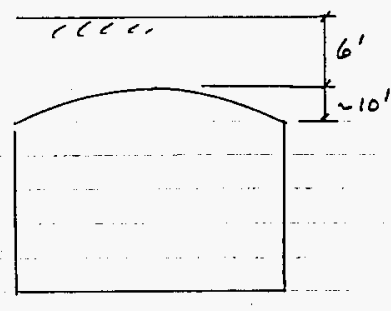

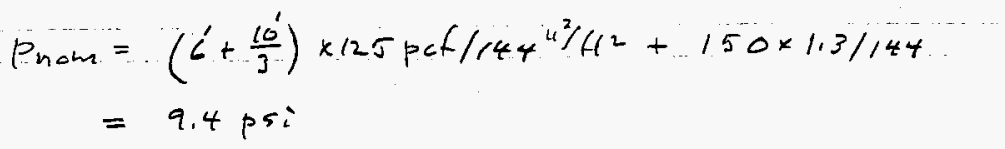

143

G.P.O.

$6 A 9-996$

121 
$\underset{\text { HANFORD }}{\text { HANGER ENGINEERS }}$

WHC-SD-WM-TI-775, Rev. 0

DESIGN ANALYSIS
Call. No. P. 5-23.

Revision

Page No. 21 of WO/Job No.

Subject

Location
Date 5/5/56

Checked
By EOL

By

2.4 DST /55T Internal veccesem (contd)

Allow pr per

$$
\begin{aligned}
P_{\text {nom }}+P_{V} & =\frac{1.4 P_{\text {nom }}}{0.40} \\
P_{v} & =P_{\text {nom }}\left(\frac{1.4}{.4}-1\right)=9.4 p_{5}\left(\frac{1.4}{.4}-1\right)=23.5 \text { ps: } \\
& >8 \text { psi } 0 k
\end{aligned}
$$

RIce dome will not collapse, but primary tank will with possible tearing.

144

tG.P.o. 689-996 12/9

7 


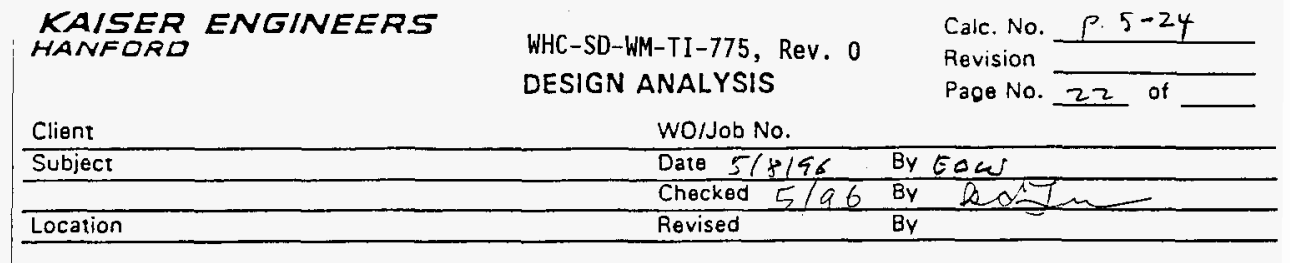

2.5 DST gasdine burn in annulus (140 psi)

Check primary tank cyl. Lucking (ERSC)

$$
\begin{aligned}
& t \text { varies from } 3 / 8^{\prime \prime} \text { to } 3 / 4^{\prime \prime} \\
& L=32^{\prime} r=37.5^{\circ} \quad L / v=32 / 37.5=.85 \\
& \operatorname{trg} 3 / g^{\prime \prime} t: t / r=.375 / 14.37 .5=.00083 \\
& \beta=3<-5
\end{aligned}
$$

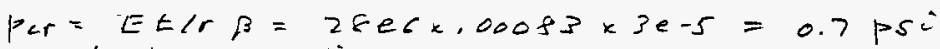

$$
\begin{aligned}
& p_{L}=1 / 2 p_{\omega r}=0.4 p_{5 i} \\
& \text { for } t=3 / 4^{4}: t / r=.00163 \quad \beta=12-5 \\
& \text { Per }=2406 \times .00164 \times 70-5=3.2+5 i \\
& p_{m}=\frac{1}{2} F_{e r}=1.6 \text { pr: }
\end{aligned}
$$

Cyl collapse occurs easily on primary taunt check primary tank dome louctiong (ERSC)

$$
\begin{aligned}
& t=31 e^{*} \quad R=100^{\prime} \\
& p_{k}=0.18 \times 1.21 E(t / R)^{2}=0.18 \times 1.21 \times 28 e 6(.375 / 1200)^{2} \\
& =0.6 \text { ps: (dome collapse w/okechor supp't) }
\end{aligned}
$$

check torus: $t=3 / 8^{\prime \prime} r=4^{\prime} L=\operatorname{long} \cdot 4 \mathrm{se}$ cyl $L / \mathbb{R}=40$

$$
\begin{aligned}
& t / r=3 / 5 / 12 / 4=.0078 \quad \beta=1.9 e-5 \\
& p_{c r}=E t / r \beta=28 e 6 \times .0078 \times 1.9 e-5=4 p 5 i \\
& p_{u}=\frac{1}{2} p_{c r}=2 p s i \quad \text { (collapse expected) }
\end{aligned}
$$

secondary liner is not connected to primary tanta.

Collapse conditions above show gases pass in belsen primary bat dome and concrete macro. 689-996 12/9
\[ 145 \] 
KAISER ENGINEERS

WHC-SD-WM-TI-775, Rev. 0

DESIGN ANALYSIS

Call. No. P. J-2

Revision

Page No. 23 of

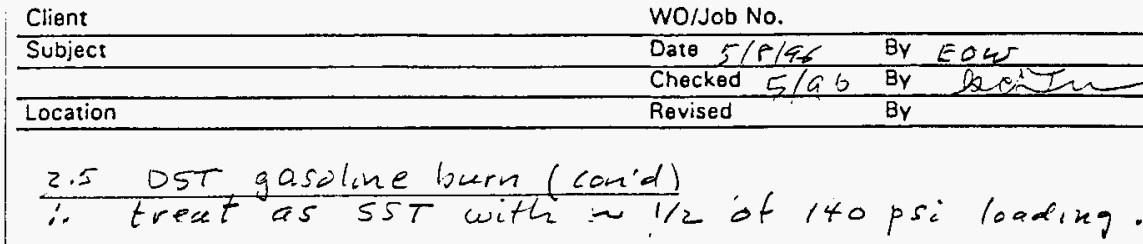

Note

Plenum: $V \approx \frac{1}{2} \overline{4} 37.5^{2}(15-6)=20000 \mathrm{ft}^{3}$

Annulus $V=2 \pi \times 38.8 \times 2.5 \times 33=.20000 \mathrm{ft}^{3}$

ie., gases could expand 2:I Into primary tanto plencem (reason for $1 / 2$ of 140 psi loading). Recent Delphi

effort had doublets about $55 \mathrm{~T}$ home integrity at $l l$ psi, so conclude dome opens up. Thinnest soil cover at center suggests opening not fall, estimate. $220^{\prime}-30^{\prime}$

146

GP. $\quad 689-996 \quad 12 / 94$ 
$\underset{\text { KANFIISER ENGINEERS }}{\text { HANG }}$

WHC-SD-WM-TI-775, Rev. 0

DESIGN ANALYSIS

Calc. No. $i^{3} \cdot j-26$

Revision

Paoe No. 24 of

Client WO/Job No.

Subject Int vec/Feimiel Goroline Date 5/96 By EDe

Location Checked 5196 By

Referevios

WHC-SO-WM-067 12+4 A

ERSC, 1988, "Bactiong of sfeer Shells, Euroitean

Recommendation," ECCS Technical Commotle 8, 19e8.

No 56

Scott 1996, "Accelerated Safety Analyses, Structural Analyses Phase II, Double-shed Waste Slorege Tank Evaluations of the Dome, Haunch, Wall \& Footong", WHC-SO-WM-SARR-O40, REKO., WHL.

Asce 4-86, "Sersmic Anaigses of Safety-lealated Nuclear structures and Commentery..," ASCE Standerd 4-86, Sep 1986.

Ramble, 1983, "Single Shell waste Tank Load Sensitivity study, SD-RE-TI-0.2, RHO

147

54-4300-037 KEH-0037.00 106/92! 

WHC-SD-WM-TI-775, Rev. $0 \quad P .7-1$
Appendix 7

High Temperature Waste Sludge 
subject Tank Farm Accident Load Evaluation

checked $5 / 96$

By

EO Wener

\section{OBJECTIVE}

Assess the potential for high temperature waste sludge to cause a loss of confinement. Assume the sludge temperature is $600^{\circ} \mathrm{F}$ and the sludge is stored in the tank for one year. Apply the sludge temperature as the inside surface temperature for the bottom half of the tank wall and apply an assumed inside surface temperature of $250^{\circ} \mathrm{F}$ for the upper half or the tank wall and dome. For Double-Contained Receiver Tanks (DCRTs), where the steel tank is not in direct contact with the vault of caisson structure, assume a temperature of $250^{\circ} \mathrm{F}$ for entire inside surface of the vault structure, including the cover. Assume a through wall temperature gradient for concrete foundations, walls, and covers that is half of the difference between the inside surface temperature and an assumed ambient temperature of $50^{\circ} \mathrm{F}$, unless a more appropriate temperature gradient can be established and justified.

\section{FINDINGS:}

Per Reference ASME, the yield strength of a typical carbon stee] (SA516) reduces from $32 \mathrm{ksi}$ at normal temperature to $23.6 \mathrm{ksi}$ at $600^{\circ} \mathrm{F}$, it is about $26 \%$ reduction. In genera 1 , the steel tanks may survive at $600^{\circ} \mathrm{F}$ without combining with any other load such as seismic load.

The degradation of Hanford concrete properties at elevated temperature for one year are shown in the table on page 3 . After one year at $600^{\circ} \mathrm{F}$, the modulus of elasticity of concrete reduce to $14 \%$ of original value, and the splitting tensile strength is $57 \%$ of the original value. The thermal expansion coefficient for Hanford concrete is $4 \times 10^{-6}$, and the coefficient for steel is $6.5 \times 10^{-6}$. The concrete vault 1 ike $7 y$ cracks through the total thickness due to the difference of thermal expansion between the steel rebar (and steel liner if it exist at that high temperature) and concrete. The rebar and/or steel liner are the only supporting mechanism after the concrete cracks completely. In this high temperature case, the compressive force in the reinforced concrete increases the bending capacity of the concrete member. The soil pressure and massive concrete weight increase the safety factor of the concrete vault. Al06 tank has been recorded at a temperature closed to $600^{\circ} \mathrm{F}$, and it has not been collapsed.

Now the question is whether the dome or top cover of the confinement will be broken, and open up to the atmosphere. It is assumed that the temperature at inside surface of concrete dome is about $250^{\circ} \mathrm{F}$ and the outside surface is about $150^{\circ} \mathrm{F}$. There is no significant degradation on concrete properties if the concrete temperature keeps below $200^{\circ} \mathrm{F}$. The compressive strength of concrete on $1 y$ reduces $16 \%$ at $250^{\circ} \mathrm{F}$ for one 
year. The cover blocks are laid on the top of the pit on top of some vaults. The edges of the blocks are free to rotate. At $100^{\circ} \mathrm{F}$ gradient through the thickness, the blocks free to bend and no moment is introduced onto the block. The concrete blocks may survive this high temperature sludge phenomena with no breach of the confinement.

The thermal moment due to through-thickness gradient will impose to existing moment at fix-end moment domes or cover slabs of the vaults. The $150^{\circ} \mathrm{F}$ to $250^{\circ} \mathrm{F}$ temperature does not effect the concrete properties significantly. But the very low Hanford concrete thermal expansion coefficient causes the concrete cracks through the dome at $130^{\circ} \mathrm{F}$ temperature rise from $70^{\circ} \mathrm{F}$ normal temperature. Because of that, the concrete cracks significantly reduce the bending capacities of the concrete. The dome or top slab is able to support its weight and the soil on top of it at high temperature has been studied. The shear capacity of the reinforced concrete is close to zero. There is no significant stress on reinforced steel, the steel should be able to hold the concrete in place without collapsing.

Some of the vaults have deep beams or mass concrete through the top slab such as 200-series tanks and 241-A-417 tank. A corner of the pump pit of 241-5-304 catch tank is located almost at the center of the cover slab. The roof slabs have been studied do not collapse due to the dead load. See Table 7.2 for failure summary due to high temperature waste sludge. 
Client. WESTINGHOUSE HANFORD COMPANY

HO/Job No.

E21425/ F6N1Al

\begin{tabular}{ccccc} 
Subject Tank Farm Accident Load Evaluation & Date May 1996 & By & K.C. Tu \\
\hline High Temperature Waste Sludge & checked $519 \mathrm{C}$ & By EOCO EC \\
\hline Location 200 East Area & Revised & \\
\hline
\end{tabular}

\section{REFERENCES/SOURCES}

ACI 1989, Building Code Requirements for Reinforced Concrete, ACI 318-89, American Concrete Institute, Detroit, Michigan.

PNL 1988, Modeling of Time-Variant Concrete Properties at Elevated Temperatures, by C. H. Henager, G. F. Piepel, W. E. Anderson, P. L. Koehmstedt, and F. A. Simonen, Pacific Northwest Laboratory, Richiand, Washington, April 1988.

RHO 1983, Single-She7l Waste Tank Load Sensitivity Study, Prepared by A. L. Ramble, Document No. SD-RE-TI-002, Rockwell Hanford Operations, Richland, Washington, March 1983.

WHC 1994, Concrete Material Characterization Reinforced Concrete Tank Structure Multi-Function Waste Tank Facility, By B. V. Winkel, Document No. WHC-SD-W236A-ER-013, Westinghouse Hanford Co., Richland, Washington, October 1994. 
Table 7.1 material properties at high temperatures

\begin{tabular}{|c|c|c|c|c|c|c|c|}
\hline \multicolumn{8}{|c|}{ DEGRADATION OF MATERIAL PROPERTIES AT HIGH TEMPERATURE } \\
\hline \multirow[t]{2}{*}{ material } & \multirow[t]{2}{*}{ designation } & \multirow[t]{2}{*}{-} & normal & \multicolumn{2}{|c|}{$250 \mathrm{~F}$} & \multicolumn{2}{|c|}{$600 \mathrm{~F}$} \\
\hline & & & (psi) & (psi) & degradation & (psi) & degradation \\
\hline carbon steel & SA-516 & fy & 32000 & 28750 & $10 \%$ & 23600 & $26 \%$ \\
\hline \multirow{3}{*}{ concrete } & \multirow{3}{*}{$\mathrm{fc}=3000 \mathrm{psi}$} & $E$ & 3122000 & 2012000 & $36 \%$ & 439000 & $86 \%$ \\
\hline & & $f c$ & 3000 & 2509 & $16 \%$ & 1592 & $47 \%$ \\
\hline & & fst & 217 & 195 & $10 \%$ & 123 & $43 \%$ \\
\hline
\end{tabular}

"material properties:

$\mathrm{fy}=$ yield strength,

$E=$ modulus of elasticity,

$\mathrm{fc}=$ compressive strength,

f'st $=$ splitting tensile strength .

NOTE: The duration for concrete at high temperature is one year. Duration is not a factor for steel. 
KAISER FNGINEERS

HANFORD

WHC-SD-WM-TI-775, Rev, 0

DESIGN ANALYSIS
Revision

Page No. 3 of

client WESTINGHOUSE HANFOFD COMPANY

to/ Job No.

$\mathrm{E} 21425 / \mathrm{F} 6 \mathrm{~N} 1 \mathrm{Al}$

subiect Tank Farm Accident Load Evaluation Date May 1996

By K.C. Tu

High Temperature Waste Sludge

Location 200 East Area

By Eocer

Table 7.2 High Temperature Waste Sludge Summary

\begin{tabular}{|c|c|c|c|c|}
\hline Tank & Structural Item & by Item & Overall & Remark \\
\hline \multicolumn{5}{|c|}{ Catch Tanks } \\
\hline $241-A-302-A$ & Steel tank & OK & OK & Buried steel tank \\
\hline $241-\mathrm{A}-417$ & Tank roof & Shear NG & OK to Atm & conc. $w / 1$ iner \\
\hline $241-A X-152$ & Cover blocks & OK & OK & concrete tank \\
\hline $241-A Z-151$ & Cover blocks & OK & OK & concrete tank \\
\hline $241-E R-311$ & Steel tank & NG & OK to Atm & $\begin{array}{l}\text { Steel tank buried } \\
\text { deep in soil }\end{array}$ \\
\hline 241-EW-151 & $\begin{array}{l}\text { Steel tank } \\
\text { Cover blocks }\end{array}$ & $\begin{array}{l}\text { OK } \\
\text { OK }\end{array}$ & OK & $\begin{array}{l}\text { Steel tank inside } \\
\text { concrete vault }\end{array}$ \\
\hline $241-S-304$ & $\begin{array}{l}\text { Steel tank } \\
R / C \text { roof }\end{array}$ & $\begin{array}{l}\text { OK } \\
\text { Shear NG }\end{array}$ & OK & \\
\hline $241-T X-302-C$ & Steel tank & OK & OK & Buried steel tank \\
\hline $241-U-301-B$ & $R / C$ tank & $N G$ & OK to Atm & By obeservation \\
\hline $241-U X-302-A$ & Steel tank & NG & OK to Atm & $\begin{array}{l}\text { Steel tank buried } \\
\text { deep in soit }\end{array}$ \\
\hline \multicolumn{5}{|c|}{ Double-Contained Receiver Tanks (DCRT) } \\
\hline $241-A-350$ & $\begin{array}{l}\text { Steel tank } \\
\text { Cover blocks }\end{array}$ & $\begin{array}{l}\text { OK } \\
\text { OK }\end{array}$ & OK & \\
\hline $244-A$ & $\begin{array}{l}\text { Steel tank } \\
\text { Cover blocks }\end{array}$ & $\begin{array}{l}\text { OK } \\
\text { OK }\end{array}$ & OK & \\
\hline 244-BX/TX/U & $\begin{array}{l}\text { Steel tank } \\
\text { Cover blocks \& roof }\end{array}$ & $\begin{array}{l}\text { OK } \\
\text { OK }\end{array}$ & OK & \\
\hline 244-CR-003 & $\begin{array}{l}\text { Stee } 1 \text { tank } \\
\text { Cover blocks }\end{array}$ & $\begin{array}{l}\text { OK } \\
\text { OK }\end{array}$ & OK & \\
\hline $244-5$ & $\begin{array}{l}\text { Steel tank } \\
\text { Cover blocks }\end{array}$ & $\begin{array}{l}\text { OK } \\
\text { OK }\end{array}$ & OK & \\
\hline \multicolumn{5}{|c|}{ 200-series single-shel1 Tanks } \\
\hline $241-\mathrm{B} / \mathrm{C} / \mathrm{T} / \mathrm{U}$ & $R / C$ tank $w /$ liner & Shear NG & OK to $A$ & \\
\hline
\end{tabular}

Notes: $N G=$ no good (fails structural criteria)

OK = satisfies structural criteria

OK to $\mathrm{Atm}=$ no significant opening to atmosphere

Shear $N G=$ no good for structural shear criteria but not collapse 


\begin{tabular}{ll} 
Revision & 0 \\
\hline Page No. 6 of
\end{tabular}

Client Westinghouse Hanford Company WO/Job No. E21425/F6N1A1

$\frac{\text { Subject Tank Farm Accident Load Evaluation }}{\text { High Temperature Waste Sludge }}$
Date May 1996 Chocked $5 / 96$ Revised By K.C.Tu Location 200 East By

\section{Concrete Properties at Elevated Temperatures}

The equations for long-termed concrete properties at elevated temperature are documented in reference PNL.

The properties are plotted versus time as follows to compare with the reference.

nominal initial compressive strength

constant value of temperature

$\mathbf{s}:=3 \quad \mathrm{ksi}$

$T:=450 \quad F$

set time

$$
1:=0.9 \quad t_{i}=i^{\frac{i}{2}} \quad \text { days } \quad \text { at } i=9 \quad 9^{4.5}=19683 \text { days }
$$

predicted modulus of elasticity (ksi)

$$
E_{\mathbf{i}}=\left(5.3947+0.1233 \cdot \mathrm{s}-0.006751 \cdot \mathrm{T}-0.1786 \cdot \ln \left(\mathbf{t}_{\mathbf{i}}+1\right)\right) \cdot 1000
$$

predicted compressive strength (psi)

$$
f_{C_{i}}:=4416.338+490.919 \cdot S-4.714 \cdot i t(T>350, T-350,0)-(230.241-1.273 \cdot i f(T>350,0,350-T)) \cdot \ln \left(t_{i}+1\right)
$$

predicted splitting tensile strength (psi)

$$
r_{s t_{i}}=448.1758+23.7436 \cdot s-0.6077 \cdot \text { if }(T>350, T-350,0)-18.4341 \cdot \ln \left(t_{i}+1\right)
$$

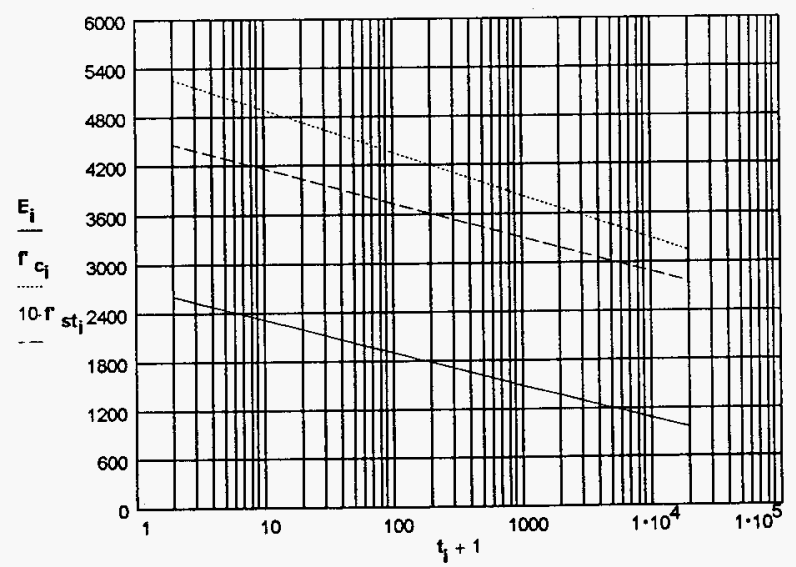

3000 psi Hanford concrete properties versus time at $450 \mathrm{~F}$

Note: The above curves match the curves on the Figures 6,9, and 12 of the reference.

$$
154
$$


Client Westinghouse Hanford Company Wo/Job No. E21425/F6N1A1 Subject Tank Farm Accident Load Evaluation High Temperature Waste Sludge Location 200 East Date May 1996 Checked $5 \longdiv { 4 6 }$ By K.C.Tu Revised By

The equations are derived for testing data in which the concrete strength values are higher than nominal values which are used in design. So that, the values should be proportional down to the nomial values.

find 28 days property values

$$
\begin{aligned}
& \text { set } i:=0.50 \quad t_{0}:=28 \text { days } i:=0 \\
& \mathbf{T}:=70 \quad \mathbf{F} \\
& E:=\left(5.3947+0.1233 \cdot \mathrm{s}-0.006751 \cdot \mathrm{T}-0.1786 \cdot \ln \left(\mathrm{t}_{\mathrm{i}}+1\right)\right) \cdot 10^{6} \cdot \mathrm{psi} \\
& E=4691 \cdot \mathbf{k s i} \\
& r_{c}:=\left[4416.338+490.919 \cdot s-4.714 \cdot \text { if }(T>350, T-350,0)-(230.241-1.273 \cdot i f(T>350,0,350-T)) \cdot \ln \left(t_{i}+1\right)\right] \cdot p s i \\
& r_{\mathbf{c}}=6314 \cdot p s i \\
& f_{\text {st }}=\left(448.1758+23.7436 \cdot s-0.6077 \cdot \mathrm{jf}(T>350, T-350.0)-18.4341 \cdot \ln \left(t_{i}+1\right)\right) \cdot p s i \\
& r_{\text {st }}=457 \cdot p s i
\end{aligned}
$$

for nominal compressive strength 3000 psi concrete

$$
\begin{array}{ll}
E_{3000}:=57 \cdot \sqrt{\mathrm{s} \cdot 1000} \cdot \mathrm{ksi} & E_{3000}=3122 \cdot \mathrm{ksi} \\
f_{\mathrm{c} 3000}:=3000 \cdot \mathrm{psi} &
\end{array}
$$

the ratio for the property equations

$$
\begin{array}{ll}
r_{E}=\frac{E_{3000}}{E} & r_{E}=67 \cdot \% \\
r_{f}:=\frac{r_{c 3000}}{r_{C}} & r_{t}=48 \cdot \%
\end{array}
$$

The concrete properties of 3000 psi concrete after one year at $600 \mathrm{~F}$ :

$$
\begin{aligned}
& T:=600 \quad F \\
& i:=1 \quad t_{1}:=365 \text { days } \\
& E:=\left(5.3947+0.1233-\mathrm{s}-0.006751 \cdot \mathrm{T}-0.1786 \cdot \ln \left(\mathbf{t}_{\mathbf{i}}+1\right)\right) \cdot 10^{6} \cdot \mathrm{psi} \\
& E=660 \cdot \mathrm{ksi} \\
& E_{600}:=E \cdot r_{E} \quad E_{600}=439 \cdot k s i \\
& r_{c}:=\left[4416.338+490.919 \cdot s-4.714 \cdot i f(T>350, T-350,0)-(230.241-1.273 \cdot i f(T>350,0,350-T)) \cdot \ln \left(t_{i}+1\right)\right] \cdot p s i \\
& r_{c}=3352 \cdot p s i \\
& r_{600}:=r_{c^{\cdot}} r_{f} \quad r c_{600}=1592 \cdot p s i \\
& f_{\text {st }}:=\left(448.1758+23.7436 \cdot \mathrm{s}-0.6077 \cdot \mathrm{if}(\mathrm{T}>350, \mathrm{~T}-350,0)-18.4341 \cdot \ln \left(\mathbf{t}_{\mathrm{i}}+1\right)\right) \cdot \mathrm{psi} \\
& \text { st }=259 \cdot \text { psi } \\
& \text { Pst }_{600}:=r_{\text {st }} \cdot \mathbf{f} \quad \text { rst }_{600}=123 \cdot \mathrm{psi} \\
& 155
\end{aligned}
$$




\begin{tabular}{ccccc} 
Client & Westinghouse Hanford Company & \multicolumn{3}{c}{ WO/Job No. E21425/F6N1A1 } \\
Subject Tank Farm Accident Load Evaluation & Date & May 1996 & By K.-C.Tu \\
\hline High Temperature Waste Sludge & Checked & 5196 & By Eo GJ \\
\hline Location_200 East & Revised & By
\end{tabular}

\section{TANK 241-A-417 DOME}

The concrete properties of 3000 psi concrete after one year at $250 \mathrm{~F}$ :

$$
\begin{aligned}
& T:=250 \quad F \\
& \mathbf{i}:=1 \quad \mathbf{t}_{\mathbf{1}}=365 \quad \text { days } \\
& E:=\left(5.3947+0.1233 \cdot \mathrm{s}-0.006751 \cdot \mathrm{T}-0.1786 \cdot \ln \left(\mathbf{t}_{\mathrm{i}}+1\right)\right) \cdot 10^{6} \cdot \mathrm{psi} \\
& E=3023 \cdot \mathrm{ksi} \\
& E_{250}:=E \cdot r_{E} \quad E_{250}=2012 \cdot k s i \\
& r_{c}:=\left[4416.338+490.919 \cdot s-4.714 \cdot i f(T>350, T-350,0)-(230.241-1.273 \cdot i f(T>350,0,350-T)) \cdot \ln \left(t_{i}+1\right)\right] \cdot p s i \\
& f_{c}=5281 \cdot p s i \\
& \mathrm{fc}_{250}:=\mathrm{r}_{\mathrm{c}} \mathrm{r}_{\mathrm{f}} \quad r c_{250}=2509 \cdot \mathrm{psi} \\
& \mathbf{r}_{\text {st }}:=\left(448.1758+23.7436 \cdot \mathrm{s}-0.6077 \cdot \mathrm{if}(\mathrm{T}>350, T-350,0)-18.4341 \cdot \ln \left(\mathrm{t}_{\mathrm{i}}+1\right)\right) \cdot \mathrm{psi} \\
& r_{\text {st }}=411 \cdot p s i \\
& \text { rst }_{250}:=\mathbf{r s t}_{\text {st }} \mathbf{r}_{\mathrm{f}} \quad \mathrm{fst}_{250}=195 \cdot \mathrm{psi}
\end{aligned}
$$

The dome is 10" thick concrete slab with \#6@6" top \& bottom and \#4@12" top and bottom the other way. Top rebar 2' clear and bottom 3/4" clear ( see Dwg. H-2-56800)

Set: The temperature at bottom surface is $250 \mathrm{~F}$, and $150 \mathrm{~F}$ at top.

thermal expansion coeficient

steel

Hanford concrete

modulus of elasticity of steel

slab depth

rebar area per inch width

distance

$$
\begin{aligned}
& { }_{a_{s}}:=6.5 \cdot 10^{-6} \\
& { }^{a_{c}}:=4.0 \cdot 10^{-6} \\
& E_{s}:=29 \cdot 10^{6} \cdot \mathrm{psi} \\
& h:=10 \cdot \mathrm{in}
\end{aligned}
$$

$$
\begin{array}{ll}
A_{1}:=\frac{.44}{6} \cdot \mathrm{in}^{2} & A_{1}=0.0733 \cdot \mathrm{in}^{2} \\
A_{2}:=\frac{0.20}{12} \cdot \mathrm{in}^{2} & A_{2}=0.0167 \cdot \mathrm{in}^{2}
\end{array}
$$

$$
\mathbf{d}_{1}=\left(.75+\frac{6}{16}\right) \cdot \text { in }
$$$$
d_{1}=1.125 \cdot \text { in }
$$$$
d_{2}:=\left(.75+\frac{6}{8}+\frac{4}{16}\right) \cdot \text { in }
$$$$
d_{2}=1.75 \cdot \text { in }
$$$$
d_{3}:=\left(10-2-\frac{6}{8}-\frac{4}{16}\right) \text {.in }
$$$$
d_{3}=7 \cdot \text { in }
$$$$
d_{4}:=\left(10-2-\frac{6}{16}\right) \cdot \text { in }
$$$$
d_{4}=7.625 \cdot \text { in }
$$ 


$\frac{\text { Calc. No. }}{\text { Revision }}-\frac{7-10}{\text { Page No. }}=\frac{0}{9 \text { of }}$

\begin{tabular}{|c|c|c|}
\hline Westinghouse Hanford Company & Wo/sob No. & $6 \mathrm{~N}: \mathrm{A} 1$ \\
\hline Subject Tank Farm Accident Load Evaluation & Date May 1996 & By K.-C.Tu \\
\hline High Temperature Waste Sludoe & Checked & By EOL \\
\hline Location 200 East & Revised & By \\
\hline
\end{tabular}

TANK 241-A-417 DOME (cont'd)

$$
\begin{array}{lll}
\text { bottom rebar tempersture } & T_{1}:=250-100 \cdot \frac{d_{1}}{h} & T_{1}=239 \\
\text { top top temperature } & T_{4}:=250-100 \cdot \frac{d_{4}}{h} & T_{4}=174
\end{array}
$$

The diference of the strain between bottom steel and concrete is

$$
\varepsilon_{d}:=T_{1} \cdot\left(\alpha_{s}-\alpha_{c}\right)
$$

The concrete cracks at strain

$$
\varepsilon_{c}:=\frac{r_{s t}}{E_{250}} \quad \varepsilon_{c}=0.000204<\varepsilon_{d}
$$

The concrete slab cracks through the thickness at main reinforcemnt direction. Then, assume no concrete at all.

$$
\sigma_{c}:=\frac{E_{s} \cdot \alpha_{s} \cdot\left(T_{1}-T_{4}\right)}{2} \quad \sigma_{c}=6126 \cdot p s i
$$

O. K. checked with computer output

tensile force required to force the section to stretch the same amount as the thermal expansion

$$
F_{r}:=\left(a_{s}-\alpha_{c}\right) \cdot\left[\left(T_{1}-70\right) \cdot A_{1}+\left(T_{4}-70\right) \cdot A_{1}\right] \cdot E_{s} \quad F_{r}=1.449 \cdot k i p
$$

deman moment due to dead load ( soil \& slab weight)

$$
\begin{array}{r}
\text { Drm : } \frac{1}{8} \cdot(125 \cdot \mathrm{pcf} \cdot(685-671) \cdot \mathrm{ft}+150 \cdot \mathrm{pcf} \cdot 1.4 \cdot \mathrm{ft}) \cdot\left[\left(\frac{26.33}{2}-5.5\right) \cdot \mathrm{tt}\right]^{2} \\
\mathrm{Dm}=1.2 \cdot \frac{\mathrm{kip} \cdot \mathrm{ft}}{\mathrm{in}}
\end{array}
$$

\begin{tabular}{|c|c|c|c|}
\hline Yield stress & & $f y:=f_{250}$ & $f y=36 \cdot k s i$ \\
\hline Modulus of & $y$ of steel & Es : $=29000 \cdot \mathbf{k s i}$ & \\
\hline dimensions: & Effective width & $b:=1 \cdot$ in & \\
\hline & Thickness & $h:=10 \cdot$ in & \\
\hline & Total area & $\mathbf{A g}:=\mathbf{b} \cdot \mathbf{h}$ & $A g=10 \cdot \mathrm{in}^{2}$ \\
\hline
\end{tabular}

check concrete slab

Compressive strength of concrete $\mathrm{fc}:=\mathrm{fc} 250 \quad \mathrm{fc}=\mathbf{2 5 0 9} \cdot \mathrm{psi}$

Yield stress for rebar at $250 \mathrm{~F}$

$$
\text { fy }_{250}=40 \cdot \mathrm{ksi} \cdot \frac{29.2+28.3}{32.0 \cdot 2} \quad \text { fy }_{250}=36 \cdot \mathrm{ksi}
$$

See ASME Section Il, Code Case, Specification no. SA-516 Gr.60 from table 3 on p. 217. 


\begin{tabular}{l}
$\frac{\text { Client Westinghouse Hanford Company }}{\text { Subject Tank Farm Accident Load Evaluation }}$ \\
High Temperature Waste Sludge \\
\hline Location 200 East
\end{tabular}
Date May 1996 checked $5 / 46$ By K.-C.Tu Revised By EOW

\section{TANK 241-A-417 DOME (cont'd)}

\section{Rebar informations:}

Tensile side rebar area

Distance from extreme compression

fiber to tension rebar

$$
\begin{aligned}
& \text { As }:=A_{1} \\
& d:=h-d_{1} \\
& A^{\prime} s:=A_{1} \\
& d^{\prime}:=h-d_{4}
\end{aligned}
$$$$
\text { As }=0.0733 \cdot \mathrm{in}^{2}
$$

Compressive side rebar area$$
d=9 \cdot \text { in }
$$

Distance from extreme comp$$
A^{\prime} s=0.0733 \cdot \mathrm{in}^{2}
$$

rression fiber to compression rebar

$\mathbf{d}^{*}=2.375 \cdot$ in

Ratio of tension reinforcement

$$
p:=\frac{\text { As }}{\text { b.d }}
$$$$
p=0.8263 \cdot \%
$$

$A C I$ 318-89 (10.5.1) minimum reinforcement required

$$
P_{\min }:=\frac{200 \cdot \mathrm{psi}}{\mathrm{fy}} \quad P_{\min }=0.5565 \cdot \%
$$

ACI 318-89 (10.5.2)

$$
\text { As : }=\text { if }\left(\rho>\rho \min , \text { As, } \frac{\text { As }}{1.33}\right)
$$

ACl 318-89 (12.2.7.3) Factor $\beta_{1}$

$$
\beta_{1}:=\operatorname{if}\left[\mathrm{fc}<4000 \cdot \mathrm{psi}, 0.85, \mathrm{if}\left[\mathrm{fc} \leq 8000 \cdot \mathrm{psi},\left(0.85-\frac{\mathrm{fc}-4000 \cdot \mathrm{psi}}{1000 \cdot \mathrm{psi}} \cdot 0.05\right), 0.65\right]\right] \quad \beta_{1}=0.85
$$

Set the maximum strain at the extreme compression fiber

$$
\varepsilon_{c}:=.003
$$

Assume the depth of equivalent rectangular stress block (neglect A's)

$$
a_{n}:=\frac{\text { As.fy }}{0.85 \cdot f c \cdot b}
$$

$$
a_{n}=1.236 \cdot i_{n}
$$

Guess value:

$$
x:=\frac{a_{n}}{p_{1}}
$$

Given

$$
\begin{aligned}
& .85 \cdot f c \cdot b \cdot B_{1} \cdot x+A^{\prime} \cdot\left(E s \cdot s c \cdot \frac{x-d^{*}}{x}-0.85 \cdot f c\right)-A s \cdot f y=0 \cdot l b \\
& c_{n}:=\text { find }(x) \\
& c_{n}=2.066 \cdot \text { in } \quad<d^{\prime} \text { change the above formula } \quad d^{\prime}=2.375 \cdot \text { in }
\end{aligned}
$$

Given

$$
\begin{aligned}
& .85 \cdot f c \cdot b \cdot \beta_{1} \cdot x+A^{\prime} s \cdot\left(E s \cdot 8 c \cdot \frac{x-d^{\prime}}{x}\right)-A s \cdot f y=0 \cdot l b \\
& C_{n}:=\operatorname{find}(x) \\
& c_{n}=2 \cdot \text { in } \\
& a_{n}:=\beta_{1} \cdot c_{n} \\
& a_{n}=1.7316 \cdot \text { in } \\
& f s:=E s-E c \cdot \frac{c_{n}-d^{*}}{c_{n}} \\
& \text { ts }=-14428 \cdot p s i
\end{aligned}
$$




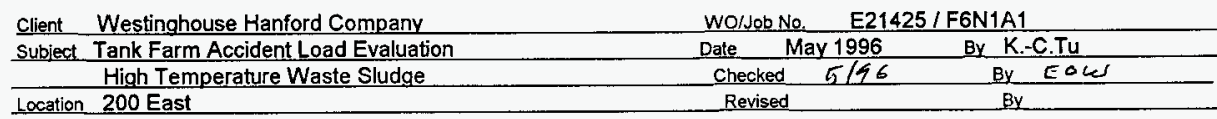

\section{TANK 241-A-417 DOME (cont'd)}

For moment equilibrium: ( $\mathrm{Po}=0$ )

$$
\begin{aligned}
& \mathrm{Mn}:=\mathrm{As} \cdot \mathrm{fy} \cdot\left(\mathrm{d}-\frac{h}{2}\right)-\mathrm{A}^{\prime} \mathrm{s} \cdot \mathrm{fs} \cdot\left(\frac{\mathrm{h}}{2}-\mathrm{d}^{*}\right)+.85 \cdot \mathrm{fc} \cdot \mathrm{b} \cdot \mathrm{a} n \cdot\left(\frac{\mathrm{h}}{2}-\frac{a_{n}}{2}\right) \\
& \mathrm{Mn}=28259 \cdot \mathrm{in} \cdot \mathrm{lb} \quad \mathrm{Mn}=2.355 \cdot \mathrm{ft} \cdot \mathrm{kip} \\
& \phi:=0.90 \text { for tenion region } \\
& \phi M n:=M n \quad \phi M n=2.119 \cdot \mathrm{ft} \cdot \mathrm{kip}
\end{aligned}
$$

maximun allowable tensile force

$$
\text { Tf : }=0.9 \cdot f y \cdot(\text { As }+ \text { A's }) \quad T f=4.744 \cdot \mathrm{kip}
$$

allowable mement for tensile force

$$
\begin{array}{ll}
\mathrm{Ma}:=\mathrm{Mn} \cdot\left(\frac{\mathrm{Tf}-\mathrm{Fr}}{\mathrm{Tf}}\right) & \mathrm{F}_{r}=1.449 \cdot \mathrm{kip} \\
\mathrm{Ma}=1.472 \cdot \mathrm{kip} \cdot \mathrm{tt}> & \mathrm{Dm}=1.2 \cdot \mathrm{kip} \cdot \frac{\mathrm{ft}}{\mathrm{in}} \quad \text { O. K. }
\end{array}
$$


Client Westinghouse Hanford Company Date May 1996 High Temperature Waste Sludge Revised By

\section{SERIES TANK DOME}

concrete strength $=2500$ psi at 28 days ( see Dwg. HW-72417)

The dome is one foot thick concrete slab with 1" dia. steel each way at top and bottom. (See Ref. RHO, p. E-11)

The concrete properties of 2500 psi concrete after one year at $250 \mathrm{~F}$ :

$$
\begin{aligned}
& \mathrm{S}:=2.500 \mathrm{ksi} \quad \mathrm{T}=250 \\
& E:=\left(5.3947+0.1233 \cdot s-0.006751 \cdot T-0.1786 \cdot \ln \left(\mathbf{t}_{\mathbf{i}}+1\right)\right) \cdot 10^{6} \cdot \mathrm{psi} \\
& E=3 \cdot 10^{6} \cdot p s i \\
& \mathrm{Ec}_{2500}=\mathrm{E} \cdot \mathrm{r} \mathrm{E} \quad \mathrm{Ec}_{2500}=1.971 \cdot 10^{6} \cdot \mathrm{psi} \\
& r_{c}=\left[4416.338+490.919 \cdot S-4.714 \cdot \mathrm{if}(T>350, T-350,0)-(230.241-1.273 \cdot \mathrm{ff}(T>350,0,350-T)) \cdot \ln \left(t_{i}+1\right)\right] \cdot p s i \\
& r_{c}=5036 \cdot p s i \\
& \mathrm{fC}_{2500}:=\mathrm{f}_{\varepsilon} \cdot \mathbf{r}_{\boldsymbol{f}} \quad \mathrm{rc}_{2500}=2393 \cdot \mathrm{psi} \\
& r_{s t}:=\left(448.1758+23.7436 \cdot s-0.6077 \cdot i f(T>350, T-350,0)-18.4341 \cdot \ln \left(t_{i}+1\right)\right) \cdot p s i
\end{aligned}
$$

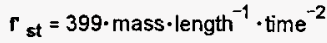

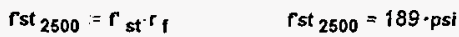

rebar area

$$
A_{r}:=\frac{0.79}{12} \cdot \mathrm{in}^{2}
$$$$
A_{r}=0.0658 \cdot \mathrm{in}^{2}
$$

slab thickness

$$
h:=12 \cdot \text { in }
$$

distance

$$
\begin{array}{ll}
d_{1}:=\left(.75+\frac{8}{16}\right) \cdot \text { in } & d_{1}=1.25 \cdot \mathrm{in} \\
d_{2}:=\left(.75+\frac{8}{8}+\frac{8}{16}\right) \cdot \text { in } & d_{2}=2.25 \cdot \text { in } \\
d_{3}:=\left(12-.75-\frac{8}{8}-\frac{8}{16}\right) \cdot \text { in } & d_{3}=9.75 \cdot \text { in } \\
d_{4}:=\left(12-.75-\frac{8}{16}\right) \cdot \text { in } & d_{4}=10.75 \cdot \mathrm{in}
\end{array}
$$

See next page for program "CRACKPC" output.

The concrete slab cracks through the thickness in X-direction. assume no concrete at all.

$$
\begin{array}{ll}
T_{1}:=250-100 \cdot \frac{d_{1}}{h} & T_{3}:=250-100 \cdot \frac{d_{3}}{h} \\
T_{1}=240 & T_{3}=169 \\
\sigma_{c}:=\frac{E s \cdot \alpha_{s} \cdot\left(T_{1}-T_{3}\right)}{2} & \sigma_{c}=6676 \cdot p s i
\end{array}
$$

O. K. checked with computer output

tensile force required to force the section to stretch the same amount as the thermal expansion

$$
F_{r}:=\left(\alpha_{s}-\alpha_{c}\right) \cdot\left[\left(T_{1}-70\right) \cdot A_{r}+\left(T_{3}-70\right) \cdot A_{r}\right] \cdot E_{s}
$$

deman moment due to dead load ( soil \& slab weight)

$$
\text { Drn : }=\frac{1}{8} \cdot(125 \cdot \text { pef } 11 \cdot t t+150 \cdot \text { pef. } 1 \cdot \pi) \cdot((10-2-1) \cdot t)^{2}
$$

$$
F_{r}=1.281 \cdot k i p
$$$$
\text { By }
$$ 

E21425/F6N1A1

Client Westinghouse Hanford Company WO/Job No Subject Tank Farm Accident Load Evaluation High Temperature Waste Sludge Date May 1996

Location 200 East Checked $5 \longdiv { 9 6 }$ Revised By K.-C.Tu 200 SERIES TANK DOME (cont'd) check concrete slab

Compressive strength of concrete $\mathrm{rc}:=\mathbf{r c} \mathbf{2 5 0 0}$ fc $=2393 \cdot p s i$

Yield stress for rebar at $250 \mathrm{~F}$

$$
\text { fy }:=40 \cdot \mathrm{ksi} \cdot \frac{29.2+28.3}{32.0 \cdot 2}
$$

$f y=36 \cdot k s i$

Modulus of elasticity of steel

$$
\text { Es : }=29000 \cdot \mathbf{k s i}
$$

dimensions:

$$
\begin{array}{ll}
\text { Effective width } & b:=f \cdot \text { in } \\
\text { Thickness } & h:=12 \cdot \text { in } \\
\text { Total area } & \mathrm{Ag}=\mathrm{b} \cdot \mathrm{h}
\end{array}
$$$$
\mathrm{Ag}=12 \cdot \mathrm{in}^{2}
$$

Rebar informations:

Tensile side rebar area

Distance from extreme compression

fiber to tension rebar

$$
\begin{aligned}
& \text { As }:=A_{\mathbf{r}} \\
& \text { d }:=h-d_{1} \\
& A^{\prime} s:=A s \\
& d^{\prime}:=h-d_{3}
\end{aligned}
$$$$
\text { As }=0.0658 \cdot \mathrm{in}^{2}
$$

Compressive side rebar area$$
d=11 \cdot \text { in }
$$

Distance from extreme comp$$
A^{\prime} s=0.0658 \cdot \mathrm{in}^{2}
$$
rression fiber to compression rebar$$
d^{\prime}=2.25 \cdot \text { in }
$$

Ratio of tension reinforcement

$$
p:=\frac{\text { As }}{\text { b.d }}
$$

ACl 318-89 (10.5.1) minimum reinforcement required

ACI $318-89$ (10.5.2)

$$
P_{\min }:=\frac{200 \cdot p s i}{f y}
$$$$
\rho_{\text {min }}=0.5565 \cdot \%
$$

ACl 318-89 (12.2.7.3) Factor $\beta_{1}$

$$
\beta_{1}=\text { if }\left[\mathrm{fc}<4000 \cdot \mathrm{psi}, 0.85, \text { if }\left[\mathrm{fc} \leq 8000 \cdot \mathrm{psi},\left(0.85-\frac{\mathrm{rc}-4000 \cdot \mathrm{psi}}{1000 \cdot \mathrm{psi}} \cdot 0.05\right), 0.65\right]\right] \quad \beta_{1}=0.85
$$

Set the maximum strain at the extreme compression fiber

$$
\varepsilon_{c}:=.003
$$

Assume the depth of equivalent rectangular stress block ( neglect $A$ 's )

$$
a_{n}:=\frac{\text { As.fy }}{0.85 \cdot f c \cdot b}
$$

$$
a_{n}=1.163 \cdot \text { in }
$$

Guess value: $\quad x:=\frac{a_{n}}{\beta_{1}}$

Given

$$
\begin{aligned}
& .85 \cdot f c \cdot b \cdot B+x+A \cdot s \cdot\left(E s \cdot 6 c \cdot \frac{x-d}{x}-0.85 \cdot f c\right)-A s \cdot f y=0 . b b \\
& c_{n}:=\text { find }(x) \\
& c_{n}=1.952 \cdot \text { in } \quad<d^{*} \text { change the above formula } \quad d^{*}=2.25 \cdot \text { in }
\end{aligned}
$$




\section{DESIGN ANALYSIS}

Client Westinghouse Hanford Company

WO/Job No. E21425/F6N1A1

Subject Tank Farm Accident Load Evaluation

High Temperature Waste Sludge

Location 200 East

Date May 1996

checked $\$ 146$

200 TANK DOME (cont'd)

Given

$$
.85 \cdot f c \cdot b \cdot \beta_{1} \cdot x+A \cdot s \cdot\left(\operatorname{Es} \cdot c \cdot \frac{x-d^{\prime}}{x}\right)-A s \cdot f y=0 \cdot 1 b
$$

$c_{n}:=$ find $(x)$

$c_{n}=2 \cdot$ in

$$
a_{n}:=\beta_{1} \cdot c_{n}
$$

$$
f s:=E s \cdot E c \frac{c_{n}-d}{c_{n}}
$$$$
f s=-14638 \cdot p s i
$$

For moment equilibrium: $(P o=0)$

$$
\begin{aligned}
& M n:=\text { As'fy }\left(d-\frac{h}{2}\right)-A \cdot s \cdot f s \cdot\left(\frac{h}{2}-d{ }^{\prime}\right)+.85 \cdot f c \cdot b \cdot a n \cdot\left(\frac{h}{2}-\frac{a_{n}}{2}\right) \\
& M n=32104 \cdot \text { in } \cdot \mathrm{lb} \\
& \mathrm{Mn}=2.675 \cdot \mathrm{ft} \cdot \mathrm{kip} \\
& \phi:=0.9 \\
& \text { for tension region } \\
& \phi M n:=\phi M n \\
& \phi M n=2.408 \cdot f t \cdot k i p
\end{aligned}
$$

maximun allowable tensile force

$$
\text { Tf : }=0.9 \cdot f y \cdot\left(\text { As }+A^{\prime} \cdot s\right)
$$

$$
\mathbf{T f}=4.259 \cdot \mathbf{k i p}
$$

allowable mement for tensile force

$$
\begin{aligned}
& M a:=M n \cdot\left(\frac{T f-F r}{T f}\right) \\
& M a=1.684 \cdot k i p \cdot f t
\end{aligned}
$$

$>$

$$
F_{r}=1.281 \cdot k i p
$$

$$
\mathrm{Dm}=0.778 \cdot k i p \cdot \frac{\mathrm{ft}}{\text { in }}
$$

O. K. 


15 of

\begin{tabular}{l}
$\frac{\text { Client }}{\text { Sestinghouse Hanford Company }}$ \\
$\frac{\text { Tank Farm Accident Load Evaluation }}{\text { High Temperature Waste Sludge }}$ \\
\hline Location 200 East
\end{tabular}
Wo/Job No. E21425/F6N1A1

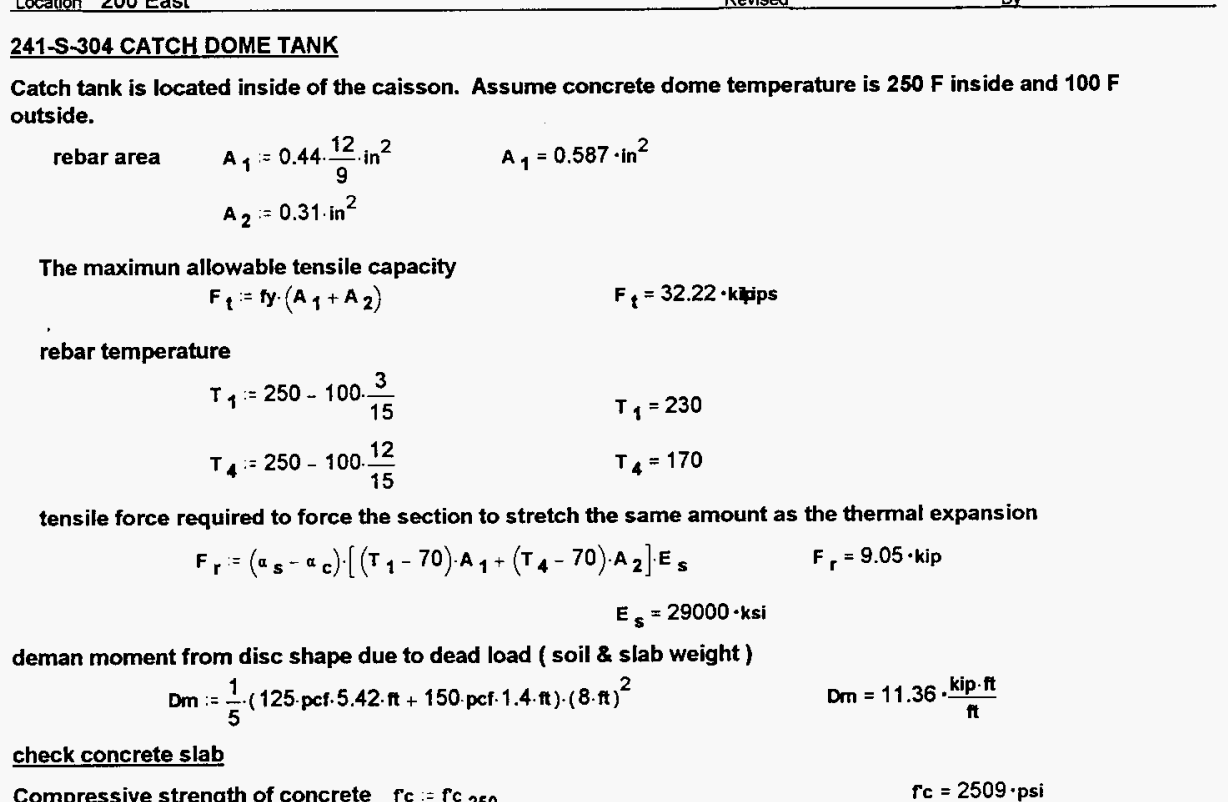

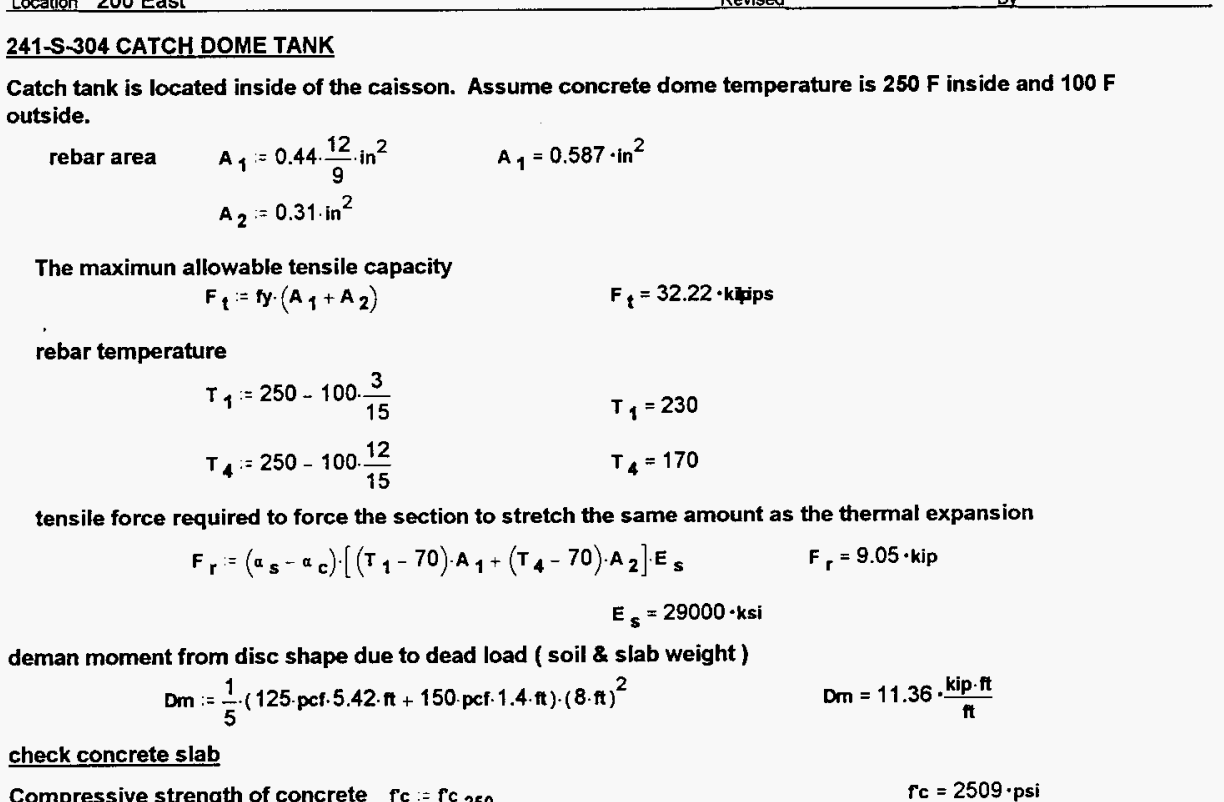

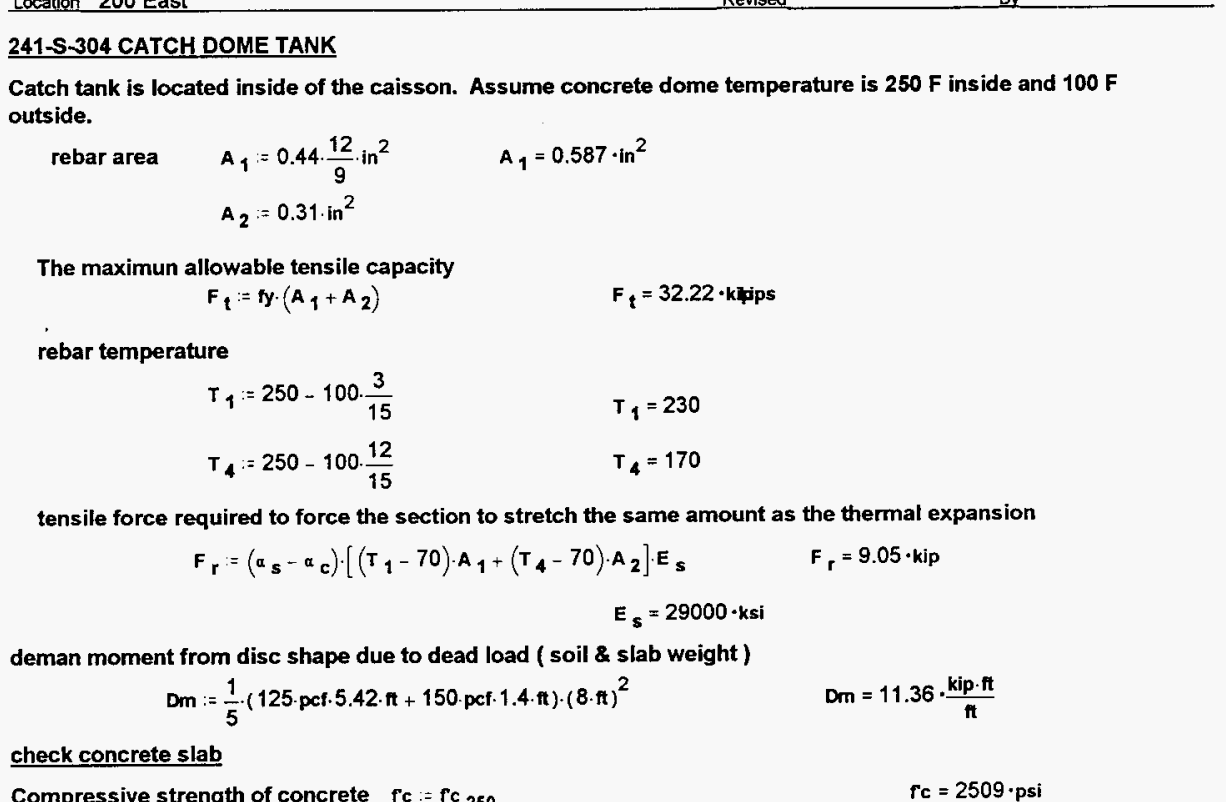

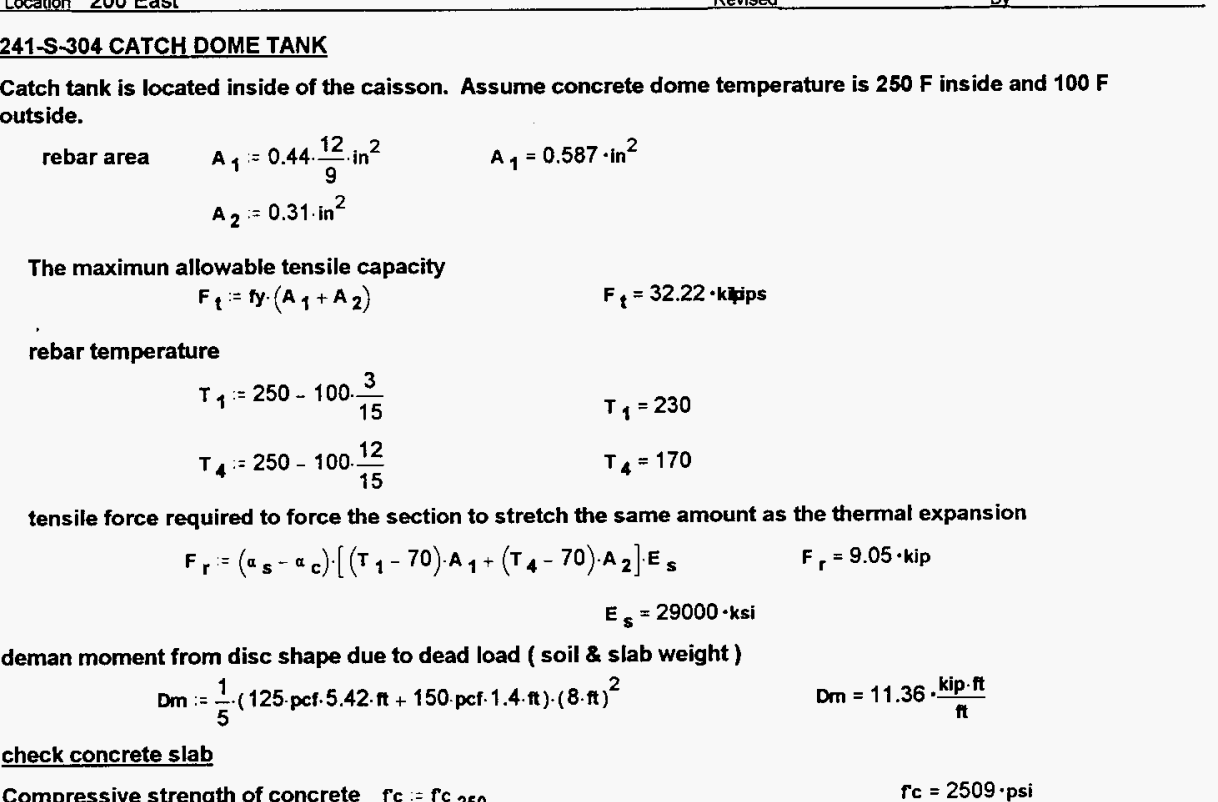

$$
\begin{array}{ll}
A_{1}:=0.44 \cdot \frac{12}{9} \cdot \mathrm{in}^{2} & A_{1}=0.587 \cdot \mathrm{in}^{2} \\
A_{2}:=0.31 \cdot \mathrm{in}^{2} &
\end{array}
$$

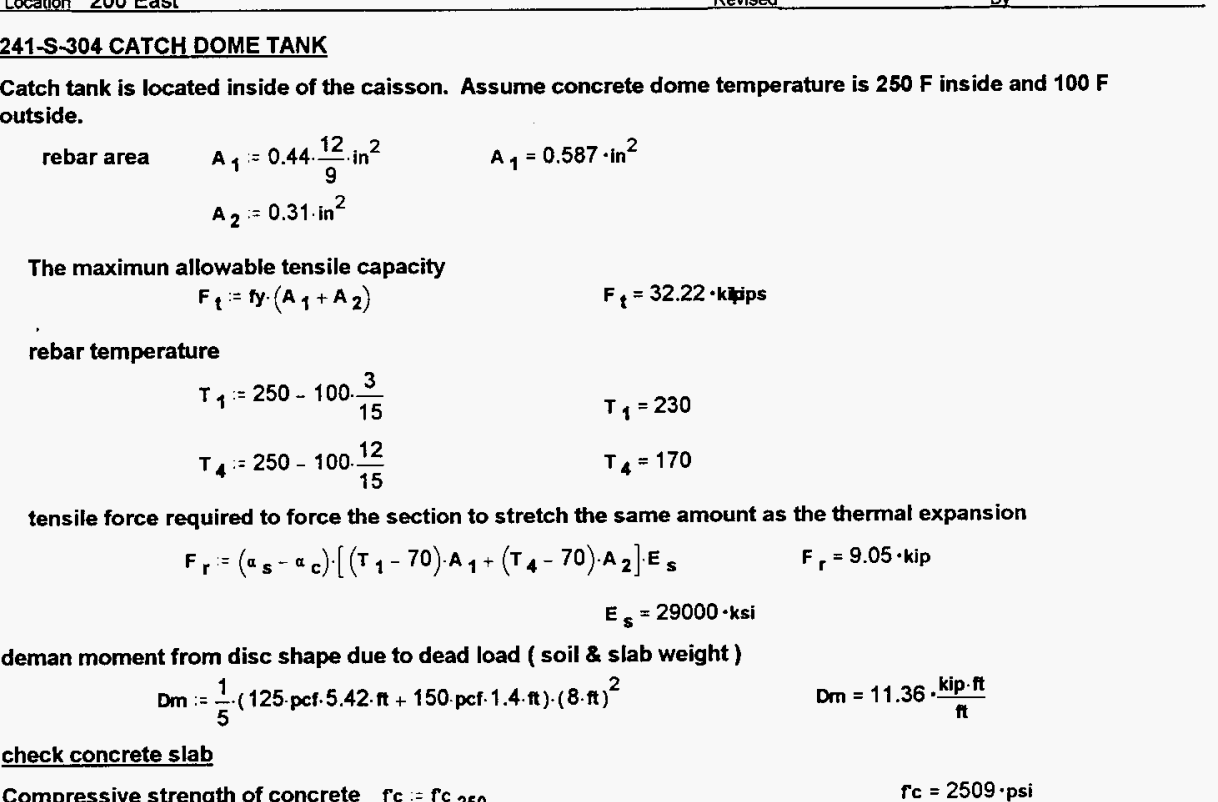

$$
F_{t}:=t y \cdot\left(A_{1}+A_{2}\right) \quad F_{t}=32.22 \cdot k \text { ipjps }
$$

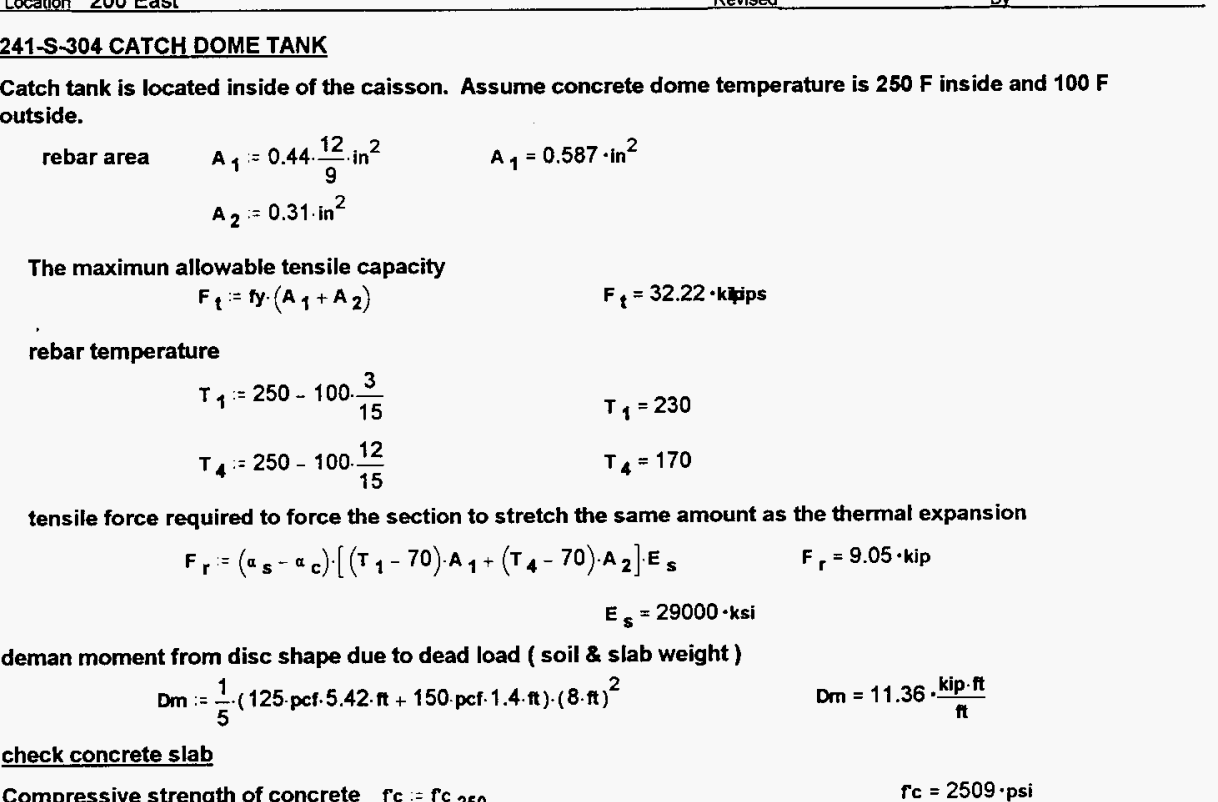

$$
\begin{array}{ll}
T_{1}=250-100 \cdot \frac{3}{15} & T_{1}=230 \\
T_{4}:=250-100 \cdot \frac{12}{15} & T_{4}=170
\end{array}
$$

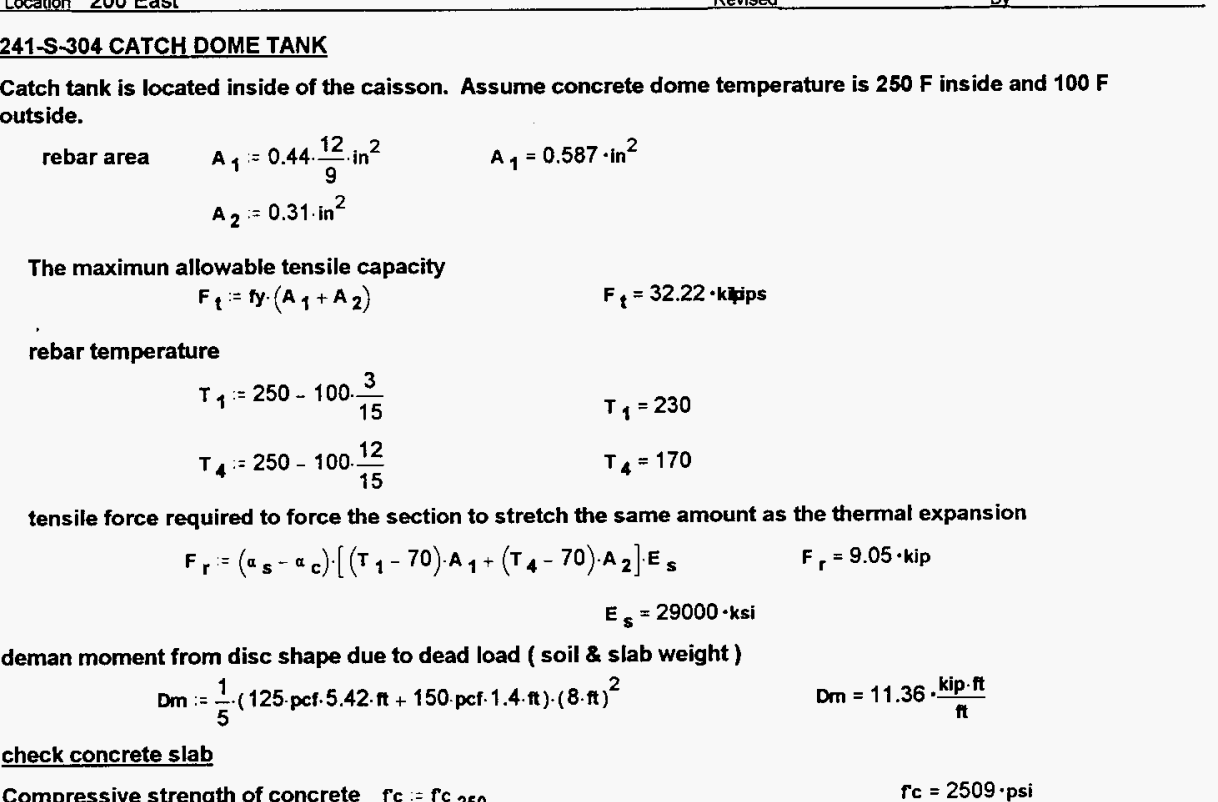

$$
\begin{aligned}
& F_{r}:=\left(a_{s}-\alpha_{c}\right) \cdot\left[\left(T_{1}-70\right) \cdot A_{1}+\left(T_{4}-70\right) \cdot A_{2}\right] \cdot E_{s} \quad F_{r}=9.05 \cdot k j p \\
& E_{s}=29000 \cdot \mathrm{ksi}
\end{aligned}
$$

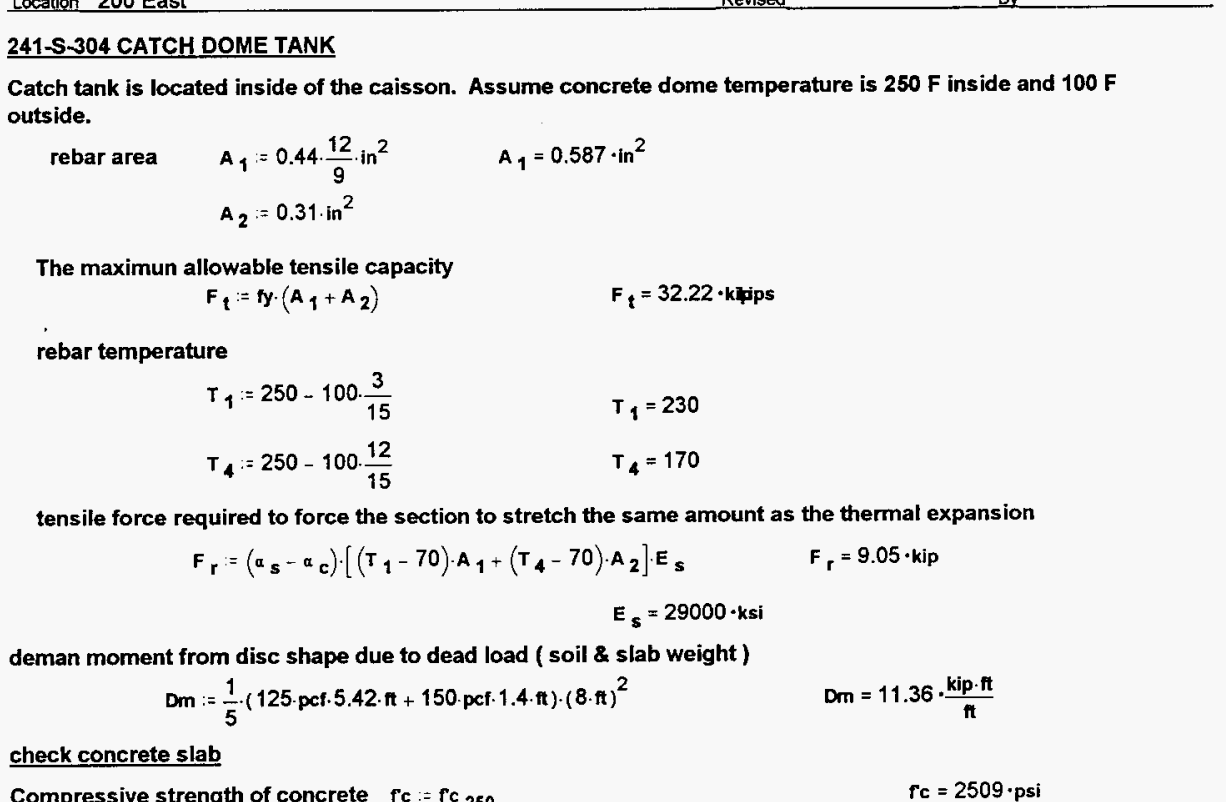

$$
\text { Dm : }=\frac{1}{5} \cdot(125 \cdot \mathrm{pcf} \cdot 5.42 \cdot \mathrm{ft}+150 \cdot \mathrm{pcf} \cdot 1.4 \cdot \mathrm{ft}) \cdot(8 \cdot \mathrm{ft})^{2} \quad \text { Dm }=11.36 \cdot \frac{\mathrm{kip} \cdot \mathrm{ft}}{\mathrm{tt}}
$$

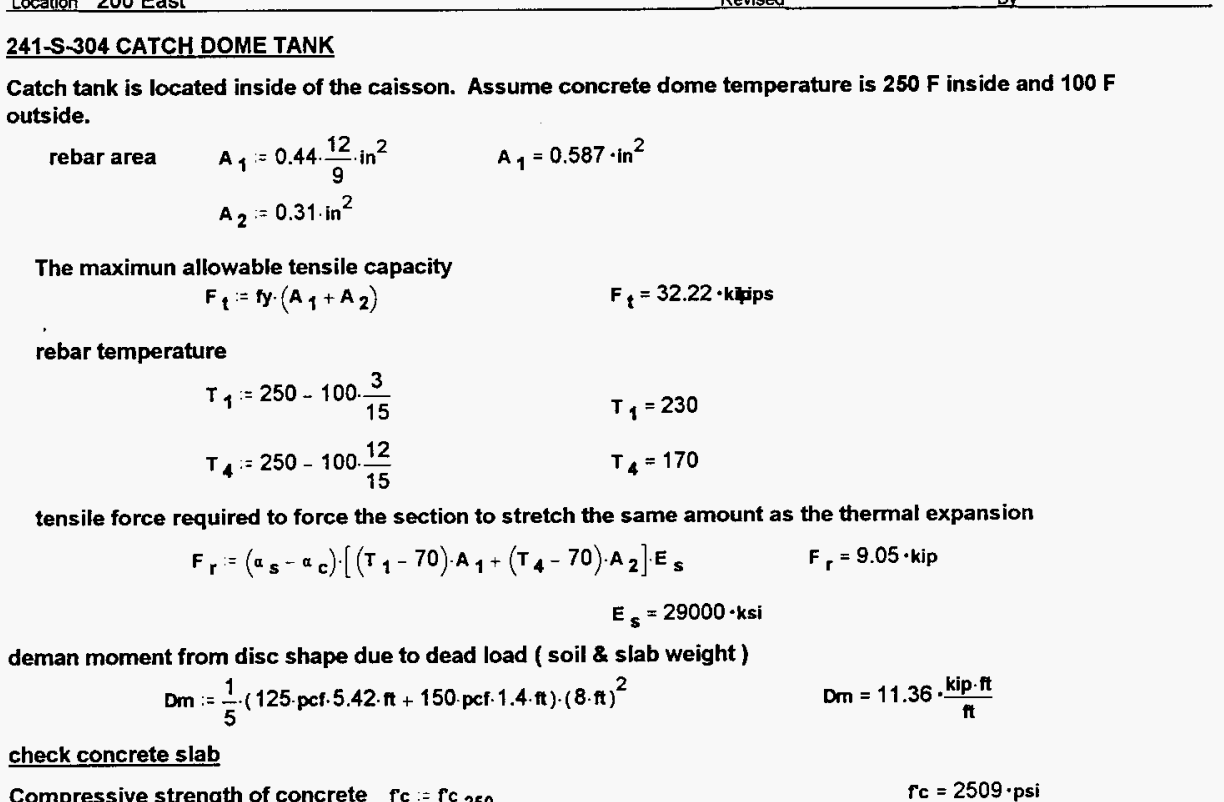

Compressive strength of concrete $f c:=f c c_{250} \quad r c=2509 \cdot p s i$

dimensions: Effective width $b:=12$ in

Thickness $\quad h:=12 \cdot$ in

Total area Ag : $=$ b.h $\quad A g=144 \cdot$ in $^{2}$

Rebar informations:

Tensile side rebar area

Distance from extreme compression

fiber to tension rebar

$$
\text { As : }=A_{1}
$$

Compressive side rebar area

$d:=\left(15-\frac{3}{4}-\frac{6}{8}-\frac{6}{16}\right) \cdot$ in

As $=0.5867 \cdot \mathrm{in}^{2}$

Distance from extreme comp

rression fiber to compression

rebar

$A^{\prime} s:=A_{2}$

$d=13 \cdot$ in

Ratio of tension reinforcement

$d^{\prime}:=\left(2+\frac{5}{8}+\frac{5}{16}\right) \cdot$ in

A's $=0.31 \cdot \mathrm{in}^{2}$

$p:=\frac{\text { As }}{\text { b-d }}$

$d^{\prime}=2.9375 \cdot$ in

$p=0.3725 \cdot \%$

reber yield stress

$$
\text { fy }:=60 \cdot k s i \cdot \frac{29.2+28.3}{32.0 \cdot 2}
$$

$\mathrm{fy}=54 \cdot \mathrm{ksi}$

ACI 318-89 (10.5.1) minimum reinforcement required

ACl 318-89 (10.5.2)

$$
\begin{aligned}
& p_{\min }=\frac{200 \cdot p s}{f y} \\
& \text { As }:=\text { if } / p>p_{\min } \\
& 16,3
\end{aligned}
$$$$
P_{\text {min }}=0.371 \cdot \%
$$ 


\section{1-S-304 CATCH TANK DOME (cont'd)}

ACI 318-89 (12.2.7.3) Factor $\beta_{1}$

$$
\beta_{1}=\text { if }\left[\mathrm{rc}<4000 \cdot \mathrm{psi}, 0.85, \mathrm{if}\left[\mathrm{rc} \leq 8000 \cdot \mathrm{psi},\left(0.85-\frac{\mathrm{fc}-4000 \cdot \mathrm{psi}}{1000 \cdot \mathrm{psi}} \cdot 0.05\right), 0.65\right]\right] \quad \beta_{1}=0.85
$$

Set the maximum strain at the extreme compression fiber

$$
\varepsilon_{c}:=.003
$$

Assume the depth of equivalent rectangular stress block (neglect A's)

$$
\text { Guess value: } \quad x:=\frac{a_{n}}{\beta_{1}} \quad a_{n}:=\frac{A s \cdot f y}{0.85 \cdot r c \cdot b}
$$

evene

$$
\begin{aligned}
& 85 \cdot f c \cdot b \cdot B_{1} \cdot x+A \cdot s \cdot\left(\text { Es: } \varepsilon \cdot \frac{x-d}{x}-0.85 \cdot r c\right)-A s \cdot f y=0 \cdot 1 b \\
& c_{n}:=\text { find }(x) \\
& c_{n}=2.034 \cdot \text { in } \quad<d^{\prime} \text { change the above formula } \quad d^{\prime}=2.938 \cdot \text { in }
\end{aligned}
$$$$
\text { Given } \quad .85 \cdot f^{\prime c} \cdot b \cdot \beta_{1} \cdot x+A^{\prime} \cdot\left(\text { Es: } \varepsilon \cdot \frac{x-d^{\prime}}{x}\right)-A s \cdot f y=0 \cdot 1 b
$$$$
c_{n}:=\text { find }(x)
$$$$
c_{n}=2 \cdot \text { in }
$$$$
a_{n}:=\beta_{1} \cdot c_{n}
$$$$
a_{n}=1.7155 \cdot \text { in }
$$$$
\text { fs : }=E s \cdot \varepsilon \cdot \frac{c_{n}-d}{c_{n}}
$$$$
\text { fs }=-39627 \cdot p s i
$$

For moment equilibrium: $(\mathrm{Po}=0$ )

$$
\begin{aligned}
& \mathrm{Mn}:=\mathrm{As} \cdot \mathrm{fy} \cdot\left(\mathrm{d}-\frac{h}{2}\right)-\mathrm{A}^{\prime} \mathrm{s} \cdot \mathrm{fs} \cdot\left(\frac{h}{2}-\mathrm{d}^{+}\right)+.85 \cdot \mathrm{fc} \cdot \mathrm{b} \cdot \mathrm{a} \cdot \mathrm{n} \cdot\left(\frac{h}{2}-\frac{\mathrm{a}_{n}}{2}\right) \\
& \mathrm{Mn}=5 \cdot 10^{5} \cdot \text { in } \cdot \mathrm{lb} \quad \mathrm{Mn}=40.729 \cdot \mathrm{ft} \cdot \mathrm{kip} \\
& \text { : }=0.9 \text { for tension } \\
& \text { tMn := } \cdot \text { Mn } \quad \text { \$Mn }=36.656 \cdot \text {. f kip }
\end{aligned}
$$

maximun allowable tensile force

$$
\text { Tf : : 0.9.fy-(As + A's) } \quad \text { Tf }=43.502 \cdot k i p
$$

allowable mement for tensile force

$$
\begin{aligned}
& M a:=M n \cdot\left(\frac{T f-F_{r}}{T f}\right) \\
& M a=29.028 \cdot k i p \cdot \pi \quad>\quad D m=11.36 \cdot k i p \cdot \frac{\pi}{n} \quad \text { O. K. }
\end{aligned}
$$


WHC-SD-WM-TI-775, Rev. 0

p. $8-1$

\section{Appendix 8}

Aging and Degradation

165 
KAISER ENGINEERS HANFORD
WHC-SD-WM-TI-775, Rev. 0

no/ Job No.

E21425 / F6N1A]

client WESTINGHOUSE HANFORD COMPANY Date May 1996

By

K.C. Tu

Aging and Degradation

checked $5 / 46$

By

roweiner

Location 200 East Area

Revised

\section{OBJECTIVE}

Assess the potential for aging and degradation mechanism to cause a loss of containment. Specifically address how each of the following mechanisms could individually affect confinement of the waste:

- corrosion

- high temperature waste

- thermal cycling

\section{CORROSION:}

There are three time-dependent corrosion mechanisms (Reference Abatt) on the steel tanks.

Pitting Corrosion:

The highest pitting corrosion rates from corrosion testing and

laboratory simulated wastes are as shown on following table:

\begin{tabular}{|c|c|c|}
\hline \multicolumn{3}{|c|}{ HIGHEST PITTING CORROSION RATES } \\
\hline PHASE & MILS PER YEAR & INCH IN 10 YEARS \\
\hline vapor & 37 & 0.37 \\
\hline vapor/1iquid & 35 & 0.35 \\
\hline 1 iquid & 6.4 & 0.064 \\
\hline
\end{tabular}

The rates are extremely conservative. The corrosion rate is depend on the type of liquid and inside surface condition of the tank. The pitting corrosion breaches at local area, and may not cause the tank collapse.

Uniform Corrosion:

The uniform corrosion are depended on the type of liquid, $\mathrm{pH}$ value, temperature, and duration. In general, the uniform corrosion rates are as follows:

\begin{tabular}{|c|c|c|c||}
\hline \multirow{3}{*}{ PHASE } & RANGE & MEDIAN VALUE & \multirow{2}{*||}{$\begin{array}{c}\text { inch per } \\
\text { ten years }\end{array}$} \\
\cline { 2 - 4 } & mils per year & mils per year & 0.008 \\
\hline vapor & $0.6-4.1$ & 0.8 & 0.002 \\
\hline vapor/liquid & $0.01-1.6$ & 0.2 & 0.002 \\
\hline liquid & $0.01-3.1$ & 0.2 & \\
\hline
\end{tabular}


Uniform corrosion should have been considered in the normal tank design. At normal condition, the uniform corrosion rate is very low, and is not a problem for about 60 years of tanks 1 ife.

\section{Stress-Corrosion Cracking:}

Stress-Corrosion Cracking occurs when tensile stress approaching or exceeding yield strength and an environment corrosive to the material are present simultaneously. The objective tanks are normally empty. Stress-Corrosion Cracking is not a concern.

Reinforcement:

The soil condition in Hanford area is dry and the reinforcement in underground concrete is in good condition. Some core drilled samples show no corrosion on the reinforced steel. If the primary tank leaks, the liquid seeps into concrete and corrodes the rebar. The concrete vault is not a water tied confinement, especially at crack section.

\section{HIGH TEMPERATURE WASTE:}

Steel Tank:

The maximum temperature has been experienced in Hanford tanks is below $600^{\circ} \mathrm{F}$ at the sludge near bottom of Al06 tank. The yield strength of carbon steel may reduce $26 \%$ of its normal strength at $600^{\circ} \mathrm{F}$, that means the factor of safety of the tank reduces up to $26 \%$ if the stress at the high temperature area is near to the yield stress.

High temperature accelerates the corrosion process, and decreases the life of the tank.

Concrete Vauit:

Concrete property values (modulus of elasticity, compressive strength, and splitting tensile strength) increase moderately years after years at concrete temperature at normal condition. But the values degrades at elevated temperature with time. The concrete properties do not degrade at temperature below $200^{\circ} \mathrm{F}$. Beyond the concrete properties degradation, the difference of thermal expansions between steel and concrete at elevated temperature. Especially the thermal expansion coefficient of Hanford concrete ( $4 \times 10^{-6}$ Reference Winkel) is less than value of the regular concrete $\left(5.6 \times 10^{-6}\right) \cdot{ }_{6}$ (Note, the thermal expansion coefficient for steel is $6.5 \times 10^{\circ}$.) At high temperature, the steel rebar and/or steel liner stretches and causes the concrete cracks, and the capacities of the concrete section decreases.

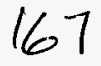




\begin{tabular}{lllll} 
client WESTINGHOUSE HANFORD COMPANY & wo/Job No. & E21425 L F6N1A1 \\
\hline subject Tank Farm Accident Load Evaluation & oate May 1996 & By & K.C. Tu \\
\hline Aging and Degradation & Checked $5 / 96$ & By EO Wecher \\
\hline Location 200 East Area & Revised & & \\
\hline
\end{tabular}

There is more detail discussion in the High Temperature Waste Sludge section of this report.

\section{THERMAL CYCLING:}

Steel Tank:

The thermal cycling do not effect on the steel tanks for the waste tanks at the temperature below $600^{\circ} \mathrm{F}$ except as it has been mentioned on the High Temperature Section.

Because of the difference of thermal expansion between steel and concrete, the thermal cycling may create the friction force between the bottom or its supporting members and the concrete foundation. The friction force may buckle the tank bottom or/and cracks the concrete.

\section{Concrete Vault:}

As mentioned previously, the concrete modulus of elasticity degrades with time at elevated temperature. The loss in modulus is not recoverable at returning lower temperature. In addition to the degradation of modulus, the thermal creep increases the instability of the concrete structure. The concrete vault behaviors highly in inelastic mode at high temperature. The deformation of the structure increases at each thermal cycle. Per Reference Anatech, there is no significant affect due to cycling after four cycles. But the concrete properties (modulus of elasticity, compressive strength, and splitting tensile strength) degrades continuously with the duration when the temperature reaches above $200^{\circ} \mathrm{F}$.

The affect of thermal cycling is direct proportional to the temperature it reaches. In general, the temperature of the objective vault at each cycle is below moderate high temperature (say $250^{\circ} \mathrm{F}$ ), the thermal cycling do not effect on the concrete vault integrity. 
Client WESTINGHOUSE HANFORD COMPANY No/Job No.

$E 21425$ / FGN1A1

subject Tank Farm Accident Load Evaluation Date May 1996 B) K.C. Tu Aqing and Degradation checked 5196 By Eo weiner

\section{REFERENCES/SOURCES}

Abatt, Double-Shell Tank Useful Life Analysis, Compiled by F. G. Abatt, Document No. WHC-SD-WM-ER-556, Westinghouse Hanford Co., Richland, Washington, 1996.

Anatech, Design-by-Analysis Methodology and Acceptance Criteria for Single Shell Waste Tank Remediation, by R. A. Dameron, R. J. James, and Y. R. Rashid, P.0. W-703916-TS, Anatech Research Corp., 5435 Oberlin Drive, San Diego, CA., September 1992.

PNL, Modeling of Time-Variant Concrete Properties at Elevated Temperatures, by C. H. Henager, G. F. Piepel, W. E. Anderson, P. L. Koehmstedt, and F. A. Simonen, Pacific Northwest Laboratory, Richland, Washington, April 1988.

Winkel, Concrete Material Characterization Reinforced Concrete Tank Structure Multi-Function Waste Tank Facility, By B. V. Winkel, Document No. WHC-SD-W236A-ER-013, Westinghouse Hanford Co., Richland, Washington, October 1994. 


\section{Appendix 9}

\section{Gasoline Ignition}

DCRTs and DSTs are evaluted structurally for a gasoline ignition event occuring in the vault or annulus and producing 140 psig pressure. The statement of work gives an instantaneous rise time and a sufficient duration which calls for a dynamic load factor (DLF) of two. Prior to the finalized statement of work, information was received with a rise time sufficiently long to suggest a lower DLF, and the attached calculations were carried out with DLF $=2$. The conclusions are no different. Little benefit is expected from large displacement effects. Consequently, the vault or annulus space was given a $1.2 \times 140 \mathrm{psi}$ static pressure loading and evaluated against the appropriate structural criteria. None of the structures pass, and an open configuration with any cover blocks blown off is concluded. With the exception of the DST, the opening is essentially the roof area. A somewhat smaller opening is expected with the DST as soil cover is thinner at the crown and the haunch concrete is at least twice as thick as the crown.

Detailed calculations are combined with those in Appendix 5, item by item.

Calculations for the gasoline ignition event are combined with the internal vacuum event under each configuration. (APP. 5)

Table 9.1. Gasoline Ignition Summary

\begin{tabular}{|l|l|l|l||}
\hline Tank & Structural Item & OK/NG by item & Overall \\
\hline \hline $241-A-350$ & Caisson roof & NG & Fully open \\
\hline $244-B X / T X / U$ & Vault roof & NG & Fully open \\
\hline $244-C R$ & Vault roof & NG & Fully open \\
\hline $244-S$ & Caisson roof & NG & Fully open \\
\hline $241-S-304$ & Caisson roof & NG & Fully open \\
\hline DST & R/C dome & NG & Open, m25' dia. \\
\hline
\end{tabular}

Notes: $\quad N G=$ no good (fails structural criteria)

OK = satisfies structural criteria 
WHC-SD-WM-TI-775, Rev. 0

Appendix 13

High Concrete Temperatures and Pressure Caused by Organic Nitrate Reaction

Item 13 of the work plan requested a review of a proposed failure mechanism for 100 -Series SSTs caused by high temperatures and internal pressure from an in-tank organic pool fire. The failure mechanism was described in a memo written by $A 1$ Webb and Robert Marusich and is attached to the work plan. The memo predicts internal pressures of 11 psig and temperatures up to 1020 degrees Kelvin. The failure mechanism predicted is: the rebar cover on the lower face of rebar spalls, the tank pressurizes cracking the concrete dome on a 2 foot by 2 foot grid, the internal gas vents through the concrete cracks, the venting gas heats the concrete and rebar to nearly 1000 degrees Kelvin damaging and reducing the strength of the concrete and rebar, the pressure then decreases allowing the dome to lower and sag at which point the dome lacks the strength to support the soil cover and the dome falls into the tank in one large cracked piece approximately 50 to 60 feet in diameter. The memo states that a crack area of 3 square meters is needed to maintain 11 psig.

We have reviewed the proposed failure mechanism and agree with the conclusion that a portion of the dome will possibly fall into the tank. The actual failure mechanism is difficult to predict and may be different from that which was proposed by Webb and Marusich.

- The soil overburden load on the dome is approximately 6 psi near the center of the dome increasing to as much as 15 psi near the haunch. The concrete dome thickness is 15 inches at the center of the dome increasing to 30 inches or more at the haunch. As such, cracking is expected to more severe near the center of the dome. Severe cracking of the dome may be limited to an area of 20 to 30 feet in diameter.

- Concrete cracking was predicted to be at 24 inch centers to coincide with the circumferential rebar placement. It is expected that the rebar cracking will be more closely spaced, more on the order of 12 inch spacing or closer and not associated with the placement of the circumferential rebar. As such, the crack width will be smaller and over a smaller area and the total crack area is estimated to be on the order of 1 square meter which is smaller than the 3 square meters needed to maintain the 11 psig internal pressure. As such the internal pressure would be greater than the 11 psig predicted.

- The 1000 degree Kelvin gas venting through the concrete cracks for up to 1500 seconds (25 minutes) duration will cause severe degradation and loss 
of strength to the concrete in the immediate vicinity of the cracks through the thickness. As such, when the pressure reduces and the dome relaxes, the concrete may not be able to sustain the compressive loads associated with the dome arching action and result in partial dome collapse. The loss of rebar strength is expected to have minimal effects on dome collapse.

The proposed organic fire conditions of $11 \mathrm{psig}$ and 1000 degrees Kelvin (1320 degrees F) are severe. Damage to the reinforced concrete tank witl occur. Portions of the dome may collapse. Even if the dome does not collapse, it will be have severe strength reductions and should be considered unsafe and unstable. 